\title{
The Forests
}

\section{of Upper India}

Whoma s.W. Wobrer 

1912 
. 


THE FORESTS OF UPPER INDIA AND THEIR INHABITANTS 



\title{
THE FORESTS OF UPPER INDIA
}

\author{
AND THEIR INHABITANTS
}

BY

THOMAS W. WEBBER

LATE FOREST SURVeyor For THE NORTH-West PROVINCES, AND

Deputy Conservator of Forests in the Central Provinces and GorakHPUR

WITH MAPS

\author{
LONDON \\ EDWARD ARNOLD \\ pablisher to the Endia Office \\ 1902
}





\section{CONTENTS}

INTRODUCTION - $\quad$ - $\quad$ - $\quad$ - $\quad$ - $\quad$ - $\quad$ -

CHAPTER I

FIRST GLIMIPE OF THE HIMALAYAN FOREST

CHAPTER II

ROADS THROUGH THE FOREST - $\quad$ - $\quad$ - $\quad$ - 14

CHAPTER III

TIGER-HAUNTED JUNGLES

22

CHAPTER IV

FOREST SURVEYING

\section{CHAPTER V}

CAMPS IN THE UPPER FORESTS - $\quad$ - $\quad$ - $\quad$ - 44

CHAPTER VI

AMONG THE SNOW PEAKS -

CHAPTER VII

DOWN IN THE DEEP VALLEYS BY THE STREAMS

$-65$ 


\section{CHAPTER VIII}

FORESTS AND RANGES OF THE MIDDLE ZONE

CHAPTER IX

THE UPPER VALLEYS AND COUNTRY OF THE BHOTIAS

CHAPTER X

HUNDACE OR HUNDES: THE LAND OF THE HUNS -

\section{CHAPTER XI}

GURLA MANDHATA AND THE SOURCES OF THE BRAHMAPUTRA

CHAPTER XII

PLAINS OF GYANIMA : HOME OF THE 'OVIS AMMON' - I34

CHAPTER XIII

NO MAN'S LAND : RAVINES, DEEP VALLEYS, AND HIGH PASSES

\section{CHAPTER XIV}

SUBALPINE REGIONS: HEAT, RAIN, AND DRIPPING JUNGLES I68

\section{CHAPTER XV}

\section{CHAPTER XVI}

FORESTS OF THE BHABAR AND FOOT-HILLS

\section{CHAPTER XVII}




\section{CHAPTER XVIII}

FORESTS OF GORAKHPUR AND NEPAL TERAI

CHAPTER XIX

JUNGLES IN CENTRAL INDIA AND BUNDELKHAND -

CHAPTER XX

THE NERBUDDA -

\section{CHAPTER XXI}

THE BORI FOREST -

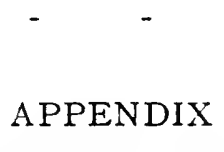

ON THE SCIENTIFIC MANAGEMENT OF FORESTS

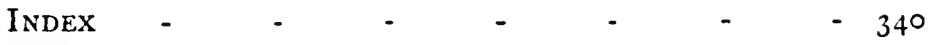

MAP OF UPPER INDIA SHOWING FOREST REGIONS

SKETCH MAP OF HUNDES AND THE HIMIALAYAN RANGE 



\section{INTRODUCTION}

THE term 'forest' has always had for me a strange fascination. Dr. Johnson defines a forest as 'a wild, uncultivated tract of ground interspersed with trees.' Italians still call strangers generally forestieri, conveying the idea that all outside the pale of civilization is forest. The Great Hercynian Forest, covering half of Northern Europe, was to the Romans an unknown region of monstrous import. Travellers in Central Africa have scarcely yet penetrated the great Forest, where strange types of men and apes of terrible proportions have been seen by a few. The human race seems actually to have sprung into existence as a forest animal, and the earliest instincts of mankind are now represented by the almost universal love of the chase. Romantic tales like that of Robin Hood and his Foresters bold are still cherished in most civilized countries. In England men still cling to the traditions of foresters, and in Germany they reverence 'the gray and the green.' In India the term 'jungle' has a similarly wide and uncertain meaning, not necessarily implying trees any more than the Scotch 'deer forest,' but signifying a region where savage animals dwell, and where wild men exist. I have been asked a hundred times what a Forest Officer in India does when engaged in his forest duties. People generally seem to look on the forests there very much as the Italians must have done-as unknown to civilized mankind. 
In commencing to write the following recollections of years spent mostly in the Forests of Upper India, principally in the Himalayas and North-West and Central Provinces, my object will be to record such incidents as may elucidate the conditions of life in the forests, and to treat of the wild animals and men met with and their habits, and also casually of the trees and plants that grow naturally there. I do not pretend to any scientific knowledge of these things, but, being a lover of Nature in all its aspects, I would try and record the results of constant observation made from time to time in the various regions visited, which were to myself highly interesting and instructive, and which I would endeavour to put into intelligible form.

Man was originally a hunting animal, and the instinct certainly is not eradicated among Englishmen yet, though there are some who have not a soul for sport. But to many men, and women too, of our country, the wild life in the forest comes quite natural and has a perfect fascination. To kill something is said by foreigners to be the daily desire of every Saxon. This is often too true; and that the big game of the world is rapidly and surely becoming extinct is probably due to the persistent energy of the Anglo-Saxon character in acting up to its proclivities. I would not write to assist such exterminators and pothunters, whose selfishness and cruelty cannot be sufficiently reprobated. It is, alas! too true that as no one will burn an ounce less coal in England because the next generation will surely run short, so the wild animals which a few years back abounded in the vast forests of Africa and Western America are now within measurable distance of becoming extinct, the present generation caring nothing for the next.

But it is not so in India. Nature has there provided 
a safeguard against the entire spoiling of its beautiful and vast forests. During the six months of the rainy season the growth is so luxuriant, and the jungles so impenetrable and unhealthy, that the wild animals have immunity from the persecution of their great enemy, the Saxon man. The natives as a rule do not take animal life ; and the paternal rule of the British Government, though it offers a reward for the destruction of snakes and animals dangerous to life, does not encourage the wholesale slaughter of the harmless creatures which the forest produces and nourishes. India will, I hope, long remain a paradise for the true sportsman, as its forests cannot become denuded of all life and so deprived of half their beauty and interest. In establishing a Forest Department and protecting the timber from destruction, the Government has also extended its protecting arm over the game, so that it shall not be exterminated in a ruthless and wasteful manner. Nevertheless, game is getting scarcer than it was. I was fortunate in being in the country at a time-shortly after the Mutiny-when game of all kinds was very plentiful, and when in most places it was easy to keep the larder and camp supplied with good venison or winged game; but to kill females, or slaughter poor innocent creatures simply to make a bag, was not thought of. I have read books on hunting big game, where the writers unblushingly describe their exploits in shooting down multitudes of innocent animals apparently for no object whatsoever. Nor do they even omit to count up the wounded ones. Such descriptions make one sick, and little the wiser as to the nature of the country or the habits of the animals. I shall not endeavour to imitate these wrongly styled sportsmen. My object was to obtain the best specimen of any particular kind of game, and to become acquainted with its conditions of life from actual experience, and 
I found this a most interesting pursuit. I would desire to record things that $I$ have seen and incidents, sometimes exciting enough, which come in the ordinary course of a day's work in the forest.

Lastly, I would try and justify the title of these pages by giving to the inquirer about forests some information as to the objects and methods of modern forestry, about which ideas are rather vague. Some imagine that forestry is the science of planting trees in ornamental plantations and lawns, on which subjects whole books have been written, with full instructions for each time of year, under the title of 'Forestry.' Some imagine that it has something to do with French or German, and that to understand about trees one must think in one or both of these languages. I quite agree that those nations are far ahead of England in the science of forestry; and having spent some time in Germany studying their system of management, I consider there is no better school or system; but when the writer commenced the survey of forests in India it was far more useful to be able to swear roundly in Hindustani, without striking or losing one's temper, than to talk French. Some, again, imagine that cutting timber is the principal work of a forester, and that a good axe is the most essential implement. In the Indian forests I have always found a good rifle and a kukri* the most useful weapons; while to be able to ride all day on an elephant without feeling the sun, and to camp out in all seasons of intense heat on the plains and of intense cold on the highest hills in the world, without taking fever, and to be always ready for a long march on foot, horse, or elephant, and for a good venison steak at the end of it, were the most approved capabilities of a Forest Officer.

The Forest Department was started, shortly before the * Gurkha hunting-knife. 
writer entered it, because Government became aware that the magnificent forests of India and Burma were being worked by private enterprise in a reckless and wasteful manner, and were likely to become exhausted if supervision were not exercised. In a country possessing thousands of square miles* of timber-growing jungle, it was found that timber for sleepers had to be imported from Norway for railway construction. The European pine wood, even when creosoted, did not remain sound for long in the climate of India, where the great alternations of extreme drought and damp heat affect timber rapidly and cause it soon to decay. The hard and heavy native timbers, such as teak and sal, are more suitable for withstanding the climate than any European wood. It became absolutely necessary to grow a constant supply of native timber, and for that purpose the existing forests were given into the charge of the new Forest Department under the supervision of skilled officers. Government availed itself of the services of what it could obtain most suitable, and selected a well-known specialist, Dr. Brandis, $\uparrow$ who was experienced in the German system of forest management, as Inspector-General of Forests. There were, beside the known teak and sal forests, great areas of waste land under jungle of sorts, almost unexplored. In order to bring these under supervision and ascertain what was worth protecting, Forest Surveyors were appointed. The writer and two assistants were selected for that post in the North-West Provinces by the Lieutenant-Governor.

Prior to this my work had been, though not actually in the Forest Department, still very much in the forest. I was employed in engineering and constructing a road

* In India and Burma 80,000,000 acres.

$\uparrow$ Now Sir Dietrich Brandis. 
from the foot of the hills up to the hill-station of Naini Tal. Road-constructing is a very important operation, which comes necessarily into the work of Forest Officers ; therefore I make no apology for including it in these recollections, and describing the work and its incidents first. Next will follow the story of the surveying of the forests, both in the hills and in the plains of North-West and Central India. Lastly I will treat of later experiences in the duties of a Forest Conservator, and the management of forests generally, and work in the districts of Gorakhpur and the Nerbudda valley and Satpura hills, in the Central Provinces. 


\section{THE FORESTS OF UPPER INDIA}

\section{CHAPTER I}

FIRST GLIMPSE OF THE HIMALAYAN FOREST

A LINE of deep red along the eastern horizon was the first signal of dawn, after a hot night of pitchy blackness.

The morning of October I6, I86I, was breaking. The dust of an unmetalled road, with the dense smoke of flaring torches, had filled the air all night long and made it unbreathable. The monotonous ' Huh, huh! huh, huh !' of the black and perspiring kahars, or dooly-bearers, as they struggled along under the weight of a primitive apparatus, made of canvas stretched on a rough framework, and called a 'dooly,' had made the night appear everlasting. There had never been a chance of five minutes' consecutive sleep for the weary traveller reclining within. The long bamboo on which the vehicle hung, borne on the shoulders of four men, while four more ran beside, taking shift every five minutes, following the masalchi, or torch-bearer, swung horribly from the trotting motion of the bearers. The suffering traveller who was borne along on that sultry night through the Terai, by the broad straight road leading from Bareilly to the foot of the Himalayan hills, would occasionally express his dissatisfaction at the swinging motion by plaintive com- 
mands. 'Step out of time' is the usual form of instruction given by the chaudhri, or head bearer; for the art of carrying a dooly steadily at a semi-running pace is never to step in time together, an error which causes the bamboo to bend with the steps of the kahars, and the unlucky passenger to be shot up and down on the elastic cordlaced bottom of the dooly like a pea on a drum. Each man is ready enough to give the order to his bhai or brother, but the steps would invariably relapse into the regular beat, of which a soldier marching would be proud, and the pole would bend and rebound with provoking elasticity. The sliding-doors at each side, if closed to keep out the dust and flare of the smelly torches, would also exclude what slight air might be stirring, and the heat inside would be stifling. Added to these discomforts, the uncertainty of finding the fresh relays of bearers at each ten mile chauki, or change, and the yelling of the tired men to announce their arrival to the fresh bearers, who might be asleep by the roadside, or perhaps still in their village, had also a disturbing effect on the traveller's sleep. Ditto the demands for backshish in addition to the legal pay already given when the $d a k$ is laid, in consideration for the unexceptionable excellence of the manner in which the stage had been performed.

Notwithstanding these drawbacks, the traveller generally found himself at the end of his forty or fifty miles' night journey by dooly dak not much the worse for a bad night's rest. He could lie at full length, and had the comfort of his own pillow and blankets, also a store of provisions and-most important-drink on the shelf above his toes. When used to it, a night's journey was about the easiest way of avoiding the sun and getting over a good many miles of road where wheeled vehicles could not travel at all, crossing ravines and water-pools in perfect 
safety. It was considered in those days quite luxurious. The traveller's light portmanteaux were borne by bahangi wallahs, who accompanied the $d a k$, swung at each end of the bahangi, an elastic yoke of split bamboo, across its bearer's shoulder. In these days of railway travelling, with sleeping and dining cars and every modern improvement, the comfort of the passenger may be superior, but he does not gain any experience of the country he passes rapidly through. He scarcely sees the scenery, and has often not an idea what the physical character of the land is like, or the people inhabiting it. His eye dwells more on the pattern of the lining of the railway carriages than the beauties of nature, and his ear, instead of receiving the new sounds of interest afforded by the language of the natives, becomes weary of the steam whistle and the invitation to feed of the cosmopolitan waiter. To have travelled through India in the old ways, by dooly $d a k$, gharry $d a k$, and bullock-train, not to speak of marching and the more rapid post-cart, is an experience worth having gone through. These thoroughly Indian methods of locomotion, the only ones in John Company's days, were no doubt tedious and full of discomfort; but the pleasure and excitement of seeing a new country on the same level as its inhabitants, and in the true Oriental manner customary in India from times immemorial, leave an impression of interest on the mind never afterwards effaced.

The breaking of the glorious day in India after such a night of darkness and uncertainty is a pleasant relief. Weariness and relaxation rapidly give way to freshness and a feeling of exhilaration as the crisp morning air is felt, and the light rapidly increases till the sun makes its way upwards. The first glimpse of the great wall of forest-clad mountains is obtained through the long vista 
ahead. The swamps and tall feathery jungle-grass of the Terai had been passed in the darkness twenty miles astern, and had given place to the dark green forests of the Bhabar through which the road was cut. This great belt of jungle, principally a close mass of tall evergreen sal trees, extends all along the base of the foot hills for hundreds of miles and ten to twenty in width, scarcely penetrated except on elephants, when the jungle fires have cleared out the luxuriant undergrowth which springs up in the rains. It is the home of every wild animal, from the elephant downwards. Troops of great white langur apes, with long tails and black grinning faces and hands, bound across the path and leap from tree to tree.

The approach to the mighty Himalayas, after seeing nothing but the dead level of the plains for so long, is very impressive, and strikes the traveller with strange anticipations. There above and before him tower the great forest-clad hills. Under his feet are actual round stones, which remind him of northern highlands, and in the blue haze of the mountains above he fancies he can see precipices of real solid rock. Beyond those distant summits which rise one over another, he knows, though he cannot see them, that there lies the everlasting snowclad range of the most lofty mountains in the world. The snowy range can be seen only rarely from Bareilly, on clear days glistening like opal among the clouds roo miles away. No wonder that the natives of the plains reverence, and fear to approach, these mysterious mountains, and do not credit that any man could walk up there without falling down. The inhabitants of the vast plains of Bengal and the Doab have most of then never seen a stone, as the level and dusty surface is all deep alluvial. To those even who have lived in moderately hilly countries, the sudden rise from the plains of the huge 
mountains of the Himalayas, with slopes and buttresses extending seventy miles from the summit, seeming like a great wall rising straight up from the plain, as the first view breaks suddenly on the sight, is mysterious and impressive, and hard to realize.

Let us sit and wonder at this scene in the verandah of the friendly rest-house which a parental Government has erected at Kaladungi ('Black Forest'), where necessary refreshment is supplied at a trifling expense. Fresh eggs and crisp chapatis are not bad fare, and the flavour and aroma of hill tea that comes straight from the Kumaon tea gardens, with sweet goat's milk, are not to be surpassed.

The group of chattering kahars, or dooly-bearers, who sit near the verandah, smoking their hubble-bubbles, squatting on their heels wrapped in brown blankets, as if it was freezing, reminds one that these tired, half-naked and very starved-looking natives of the fever-stricken Terai are waiting for their backshish, and anxious to return to their villages some twenty miles distant. Soon they are dismissed with a rupee among the lot, to add to the six annas each man has already received from the chaudhri, with perhaps the usual deductions. They are bad specimens of a nimble-footed and wiry race being decimated at this season by Terai fever, and cannot compare with the Rohilkhand kahar, who can do his sixty miles at a trot and eat only once a day.

Soon it is time to be stirring, as to-night we shall sleep 7,00o feet above the sea, in the beautiful sanatorium of Naini Tal.

A hill pony of the Bhotia race, sturdy and shaggy and about thirteen hands high, is ready for the ascent; and paharis, or hill coolies, are started by the chaprasi in charge, carrying the bedding and light baggage. The servants, horses, and heavy baggage will arrive some days 
later, having marched from the Punjab with a 'hackery,' or bullock cart.

Those who have ridden by the now little-frequented track from Kaladungi to Naini Tal will recollect the everchanging experiences of that fifteen mile ride. The ascent is gradual at first ; the road, which is a bridle-path cut through the dense sal forest on the side of the hill, following sometimes the steep spurs of the mountain, and sometimes the narrow valleys with gurgling streams; generally in the shade of evergreen trees, but often in the glare of a tropical sun. Looking back, there are occasional views of the plains below covered with endless dark-green forests of the tall and thick-foliaged sal and saj. The path-like glades and winding courses of the rivers with white, dry, shingly beds, are mapped out beneath. At this season the water which flows from the hills is all underground in the Bhabar, filtering through the shingle which has been swept down from the hills during the rains; when the rivers are foaming torrents, trending all away to the south till they disappear into the swamps of the Terai, now an ocean of yellow waving grass. The panorama becomes wider and more indistinct as one ascends, losing itself in a horizon of blue distant haze. Above, against the sky-line, there presently appear pillarlike stems, with bright-green tufted foliage, of the longleaved tropical pine (Pinus longifolia), which at 4,000 feet takes the place of the black-stemmed sal. Higher up, the forest changes to evergreen oaks of three or four kinds, and eventually to cypress and rhododendrons with profuse globes of scarlet blossom, now nearly over. There is always a rich undergrowth of elephant creepers and bright flowering begonias, followed by berberis and every sort of shrub and fern. Orchids hang from the tree-stems in quaint fashion, and the dwarf date-palm forms a graceful 
undergrowth. The sunny sides of the ravines bristle with cactus-like prickly stems of the five-sided euphorbia.* Cultivation in terraces appears in the valleys, where rice has been grown, and villages of stone-built houses roofed with shingles are occasionally met with. The inhabitants are of a new character, being Kumaon paharis, or hill-men, a hard-working and wiry race. Near the villages are plantain groves laden with spikes of fine fruit, and lemons and pommeloes adorn the gardens. Apricots, ginger, and oranges are also grown. The zamindars, or landowners, are better clothed and healthier-looking than those of the plains, but goitre is not infrequent. The lower villages are mostly deserted in the hot weather, and the families move higher up. Charcoal-burning is largely practised ; and the smelting of iron, which is found in the hills, has long been an industry, as shown by abandoned smelting furnaces and limekilns rudely built of sandstone.

A strange queer bird frequents these lower forests, called the rhinoceros hornbill. $\dagger$ He flaps along from tree to tree, as big as a goose, with dull yellow and black plumage, short wings, like a huge magpie, and long tail, making a panting sound like the piston of an engine ; but his huge head, with Israelitish expression, is his most remarkable feature, and the great yellow and scarlet knob on his hooked bill gives him a top-heavy appearance. He lights on a bough as if he had never done so before, and balances himself with difficulty, only saving himself from falling by jerks of his ugly tail. He looks down at an intruder with a cunning expression in his small beady eye, and when he opens his big mouth there is a noise that would frighten a jackass of the strongest nerves.

\footnotetext{
* Euphorbia pentaptera.

+ Dichoceros bicornis.
} 
His whole aspect and colouring are in the worst of taste, and he succeeds in being amusing without intending it in the least.

The sturdy, sure-footed pony struggles on gallantly upwards, with occasional halts to graze for a bit on the patches of real green herbage, which become more frequent as the forest is left behind, and the hills become barer and more precipitous; yet still the cliffs tower higher, and another appears against the sky as if the summit would never be reached. The rock becomes shaly and disintegrated, and looks as if the mountain was ready to topple down into the abyss below. One great landslip has already occurred, where at least a thousand feet of the precipice have gone down, leaving an awful gash in the mountain breast, where parti-coloured strata are laid bare sloping at a high angle against the sky, blocking up the khud below with acres of confused ruin. The path zigzags frantically towards a gap in the overhanging cliffs, and at length emerges on the ghat, when the scene suddenly changes and the path begins to descend through forests of oak and rhododendron into the peaceful valley of Naini Tal. Presently glimpses are obtained of the shining green waters of the lake, and pretty, red-roofed bungalows and an English church come into view. Cypresses* with pointed feathery shapes clothe the circle of surrounding hills, headed by the lofty peak of China Pahar. A wider road rejoices in the familiar name of the Mall. Evening closes rapidly. The traveller is directed to the hotel, and his journey is at an end.

To describe the well-known hill-station of Naini Tal would be superfluous in these days, when so many go to India and in India so many go to the hills. In the year I86I, however, it was a much more primitive place than 
it is at present. It had only recently been adopted as a sanatorium for troops. The Commissioner of Kumaon, Colonel Ramsay, C.B., had some years previously discovered it. There was in those days only a vague report of a beautiful and sacred valley high up in the mountains, uninhabited by any save a few jogis, or priests, but no path was known leading to it. Colonel Ramsay had gone on an expedition to explore the lofty peak of China Pahar, and came suddenly upon the lake nestled in the secluded valley close under the summit. It is not a crater, being on stratified shaly rock, and was probably formed by a gigantic slip down of half the mountain. There is no decided stream running into it, except a small one which comes out of Sukha Tal, a now 'dry lake' basin, and there is no proper overflow from it except in the rains. The water goes out in a subterranean passage, bursting forth in a good-sized torrent among the precipices at the lower end of the basin. It is surrounded by steep hills on every side, apparently clothed with dense jungle of evergreen oaks with silvery under-sides to their shiny leaves, and other beautiful evergreens. The forest was then a favourite haunt of wild animals, sambur deer and gooral (the Himalayan chamois), bears and tigers. Colonel Ramsay used to say he had seen a herd of wild elephants climbing the steep slopes of China, and that he had had such shooting as he had nowhere else found the equal of. In those early days a very steep path had been engineered up the face of the precipice from the Juli side, up which everything had to be carried on coolies' heads. Now there was a native bazaar and a number of fine level roads winding about the hill slopes, and about fifty picturesque bungalows had been built, all roofed with sheet iron, and barracks built of stone. Timber was plentiful, and lime was burnt on the spot. Colonel Ramsay, who had built 
for himself a fine two-storied house, with glazed-in verandahs, on a plateau of Aya Pathar, found it a delightful residence for the hot weather; and Naini Tal had become the summer headquarters of the North-West Provinces Government. The Lieutenant-Governor had his residence there, as well as other officials, and it soon attracted the many sufferers from the heat of the plains, and was the resort of retired servants of John Company who preferred to live out their days in the country to which they had got used, and which they loved as their home and the scene of hard and interesting lifelong work among the friends they trusted.

The difficulties of supplying a colony so large, and including invalid troops, where even the Mem Sahib's piano had to be carried up by coolies, were becoming aggravated. Government therefore decided to construct a cart-road to connect so important a station with the plains. In those days of activity and fresh awakening after the terrible troubles of the Mutiny, there was very little red tape or routine about the Government. Men of the right stamp had shone out, and worked the machine, while the inefficient and slow had dropped out of authority. Conspicuous as one who had formed and administered the provinces of Garhwal and Kumaon from their acquisition, with brilliant success, was the well-proved and honoured Colonel Henry Ramsay, C.B., * Commissioner of Kumaon and Garhwal. He had saved his division by his prompt action in promising the Gurkha sepoys the contents of the treasury at Almora, when the fate of India was hanging on a thread as it were, during the worst period of the Iutiny, when not a European soldier was near to protect the hundreds of women and children, refugees from Mussooree and the plains. He was the acknowledged * Afterwards Hon. Sir Henry Ramsay, K.C.B. 
autocrat of the hill provinces, and beloved by his faithful paharis. He not only ruled and protected the people, but also developed with skill and energy the resources of the district. He carried out extensive irrigation works at the foot of the hills, bringing vast areas under cultivation, and constructed good roads everywhere; he also, as Conservator, managed the extensive forests, containing fine timber for building and construction. His energy and ability knew no bounds. To be posted to the appointment under so able a chief on this work was a piece of good fortune to the writer of these recollections. To carry out his wishes and instructions was a pleasure, and to secure the friendship and good opinion of such a man was to attain distinction. That all his officers loved him was no wonder, as his commands were always intelligible, and he never interfered except to assist. That his subjects, the long misgoverned hill-men, worshipped him as their Mabap (father and mother) and Garib Parwar (Protector of the Poor) is a matter of history.

Naini Tal became my headquarters while the road was being engineered and constructed. November I was the usual date for commencing operations at the foot of the hills, and as the weather became hotter the camp and road operations were moved higher up. In April and May the real hot weather was on, and the work on the highest portions of the road, twenty-five miles in length, was carried on at an elevation of 7,000 feet, where the climate was hot, but the air comparatively fresh and delightful. The position for the tents was chosen near running water, and generally shaded by the thick foliage of spreading trees. June I was the signal for breaking camp and retiring to the shelter of a comfortable bungalow at Naini Tal. The natives will not work at this season, and migrate to their villages in the upper 
hills before the rains commence. Though not comparable to Simla, Naini Tal, when the season is on, is pretty well crowded with seekers after health, both civil and military, who soon put off the languid and washed-out expression of last arrivals, and manage to enjoy themselves considerably. The Lieutenant-Governor holds his tiny court, and the Mall is enlivened by crowds of the fair sex, in bright summer costumes, carried in jampans and dandis. Hill ponies are numerous, as everyone possesses one or two, and excursions to the neighbouring heights are frequent. But when the rains come, then there is a damper over everything. When the monsoon comes up with steamy cloud, and the thunder bursts and rolls around the hills, echoing from summit to summit for hours and days together, and the torrents descend till every path runs like a river, and tons of shingle are carried across the Mall and cover it up, then one is pleased to have a good staunch roof overhead, although the noise on the sheet-iron is deafening. Eleven inches in two days has been known to fall, and 200 inches may fall in six months. Then one must look out for landslips. The fate of the entire cricket ground and hotel and assembly rooms, and the library well stored with books, which used to be the scene of many hours' recreation and amusement, alas! is too well known, and the terrible tragedy that ensued; but that was years after the time of this narration.

My recollections of Naini Tal are mostly pleasant ones, and when I look at the old photographs and groups of cheerful well-known faces of good men and true friends, standing or sitting in rows by the old, well-remembered club-house, it seems that those were happy days. Alas! that if fate should ever take me to visit again the valley of the deep green lake, and to walk by that well-known path to the club I was so familiar with, I should not see 
one single face I left behind me there, and not one would know me or stretch out a hand to grasp mine. Still, the forest-clad hills would be the same, and the scene little altered. The memory of those happy years and the good kind friends will always remain, and Naini Tal will always be to me one of the fairest spots on earth. 


\section{CHAPTER II}

\section{ROADS THROUGH THE FOREST}

THE five great stars forming the shoulders and belt of Orion, with the sloping line of little stars representing the sword, shone in the blue-black heavens with a brilliancy seldom seen except in the clear atmosphere of the hills in the time of what is commonly called the cold season. A I2-foot-by-I2 'sholdarry' tent, pitched on a terrace on the slope of the hillside facing the south, with a pleasant fire of glowing logs just opposite its open door, looked like a forest home of the most agreeable kind. The cloudless starlit sky and still atmosphere, windless and not cold, made it quite delightful to sit under the canopy of heaven just outside the tent door, with the light of a lamp behind and the warmth of the wood fire in front. The remains of an excellently cooked dinner, consisting of pheasant or curried fowl, were cleared away by a native servant with snow-white puggaree and neat winter serge livery. The favourite spaniels, Ruby and Flora, lay under the table, well inside the tent, keeping one eye open to watch in case the prowling leopard might come too near, knowing well that one spring and blow of its cat-like paw would make short work of poor doggie.

The stillness was only relieved by the musical sounds of the distant stream, whose murmuring seemed to rise and fall on the ear. The faint noise of many waters came 
up from the whole length of the valley beneath the base of the hill. Opposite rose a dark and densely wooded mountain from the depths of the intervening valley, towering to meet the sky several thousand feet from the stream below. Its sharp outline cut black against the all-pervading faint light of the star-speckled vault of heaven. The bristling tree-tops on the sky-line could be discerned, and imagination wandered amongst the weird shapes of the spurs and ridges where the great chir pines tossed their umbrella-like heads aloft on pillar-like stems. There is a strange spell about the still night in such a spot, its murmurs broken only by occasional unknown sounds of nocturnal birds and animals in the neighbouring forest, sometimes near and sometimes in the far distance. The embers are dying out on the fire, all the natives in their extemporized huts have ceased to move, rolled up in their black blankets; the horses only are still awake, chewing their forage and stamping at times. A chill creeps over the relaxed limbs; it is time to turn in, to close the double flies of the thick, well-lined tent, to retire to the pleasant warmth of one's well blanketed camp bed, to lay one's head on the smooth cool pillow.

The awakening in a camp in the forest when refreshed by a good night's sleep, on a bright morning of the cold season, must be experienced to be thoroughly appreciated. The early gleams of the sun just rising over the eastern hilltops strike the white tent almost as soon as daylight comes, and soon dissipate the light mists which have fallen on every bush and herb. The dew-covered webs of many spiders glisten in the light, soon to lose their whiteness under the warmth of the sun's rays. The natives are early astir, and a blue curl of smoke rises as the fires are set a-burning. The chota haziri (or small rollcall) is the necessary first meal, which comes as a matter 
of course. The dressing being of the extemporary order, is soon got through, as the more serious bath and toilet come before the bara haziri, after morning's duties are over.

The first outlook from the tent is cheerful across the hillside terraces and glades, where brawling streamlets abound. The kakur, or barking deer, is out for his morning feed upon the tops of the tender wheat, which springs on the terraced lands. His yellow coat contrasts with the bright green of the young corn. The kalij pheasants, with their blue-black plumage and silvery drooping tails, are picking under the oaks. The native assistant-surveyor, Gaitul Singh, and a gang of coolies, are ready with light axes and pegs and hoes to commence the day's work, which consists in levelling and laying out the line of road. The road must be of a gradient not greater than 3 feet rise in Ioo, and 30 feet wide for cart traffic. The utmost skill and ingenuity are required to take advantage of every spur and ridge so as to zigzag upwards ; and with hills of a very steep and ravine-cut nature, and several thousand feet to be mounted, it is needless to observe that the turns and winds of the road, following the contours of ridge and valley, will be exceedingly perplexing. With levelling instruments and pegs it was necessary to run many trial lines before determining which was best. In some places, after following easy slopes with favourable soil for cutting out the line, like a step or terrace on the mountain-side, there appeared in front an impossible precipice too steep and dangerous for any road; and the work of levelling and pegging out a new trial line up another spur and ridge had to be gone through, till eventually the best route was found so as to avoid heavy cutting or dangerously loose precipices. The sandstone strata, dipping to the east at a high angle, 
presented an easy slope on one face, up which the road was zigzagged, gaining elevation at each tack; but when it came to rounding the extremity of the spur, the brokenoff ends of the strata formed lines of sheer precipice sloping up the face of the hill, which must be passed somehow to gain the sloping ground beyond. The line would then sweep along the slopes of a side valley overlooking a brawling stream buried in dense forest of dark sal trees, and, higher up, evergreen oaks, acacias, and a great variety of semi-tropical trees with creepers, all tangled in an impassable jungle. Then it would gain the easier slopes of a wider valley with terraced and cultivated sides, and crossing the stream at a native village, it would return along the opposite side of the valley towards the main river, gaining altitude with every mile. The morning's work entailed hard climbing among great boulders and rocks, and cutting a way through the thicket where white men had seldom before penetrated-the haunt of the tiger and other beasts of the jungle, as the tracks in the wet sand by the streams clearly showed. The coolies, however, worked cheerfully, their pleasant roices echoing amongst the rocks and glens, as they shouted to one another to indicate the direction explored, chopping at the rope-like creepers and thorny brakes until a passage was effected. The return to camp before noon for repose and breakfast was well earned, and an appetite unfailing after a cool bath made the meal an agreeable one. The dogs watch their master, and Jacko the monkey, with inscrutable expression, pretends not to see anything, but is ready to play some prank on the dogs or servants when they do not observe him.

Jacko was captured when quite a tiny baby by some boys from a troop of the common white-faced monkey, and bought for a rupee. He was not larger than a half- 
grown kitten, and had got separated from his parent when hunted from tree to tree. The boys had climbed after him to a topmost bough, whence Jacko had dropped in sheer terror to the ground, to be surrounded and seized when half stunned by the fall. His little wrinkled face was the picture of misery, and he struggled and cried piteously. The leaders of the monkey troop came round as near as they dared to recover him from the boys, who were armed with bamboos and stones, but the boys had succeeded in carrying off their prize. Poor Jacko, when sold, like Joseph to the cruel Egyptians, had soon found that he was not going to be eaten, and clung to his new master's breast as tightly as he could, his little head occasionally peeping out to see if his black and rude persecutors had departed. Friendly relations being thus established, he remained there for hours, occasionally getting a nice drink of warm milk, which he soon learnt to take out of a cup; and ever after he would fly to his warm place for safety if frightened by strange objects. At night, when his little eyes closed in sleep, he was transferred to the breast of Ruby, the spaniel dog, who lay curled up under his master's bed, and made no objection to perform the duties of nursery-maid to little Jacko. Monkeys do not grow big in a few months like puppies or kittens. They grow up slowly like children, and take several years to become boy monkeys, half-grown. A full-grown monkey is probably ten to twenty years old. When Jacko was eventually carried off by a leopard, four or five years later, he was not nearly of half-grown size. Jacko was an amusing fellow, and learnt many tricks from the mehtar who fed him-such as to salaam, and stand on his head, and 'shoulder arms' with a toy gun; but he became too mischievous to remain at large. He would put to flight any native women and children that came near the camp, 
and enjoyed himself thoroughly pulling their hair and making them scream; and then, jumping on to a tree or roof, he would give them great abuse and mimic them with strange grimaces.

The road from the foot of the hills from Kathgodam by Juli to Naini Tal took three years to construct. The first season, commencing in November, the lower twelve miles up to the Brewery were marked out and cut 6 feet wide. The work was done by native contractors of the Kumaon district, principally lohars, or iron workers. Each man with his family would take, say, a quarter-mile. They were excellent workers, the men hacking out the clay with picks and hoes, and the women dragging it away on sledges made of boards, with creepers for ropes, or sometimes of the skins of animals. The rocks were blasted and built into dry walls below, to support the stuff which came down from above. The hillsides being very steep, the work was facilitated when the rains came, large quantities of earth coming down all along the sixfoot cutting on to the track, which was completed the following year-20 to 30 feet wide-strong retaining walls being built from below to retain the material, which, after a time, became consolidated into a firm road. But in some places, where the earth was loose or springs broke out, there were disastrous landslips, and great difficulty was experienced in keeping up the road at all. The second season, the widening process had to be completed after the rains ceased. No work could be done in the rains. In some places where solid rock and precipices were met with, the entire road was blasted out of the rock, which was red sandstone, and luckily not very hard. Steel jumpers and crowbars were largely employed, and a hundred pounds of gunpowder per day were often burnt. This portion was done by coolies from Nepal, called Dotials, 
who came every year in gangs of Ioo men each for the season's work, November to May. There were over 2,500 of them at work at times. They were engaged at two annas a day each, and worked very fairly well under their own chaudhris (gangsmen), who were responsible for the work. These people are somewhat like Gurkhas. They possess but a blanket each and a lota (brass pot) to cook with, and they complain of great poverty in their own country. Their pay came seldom to a rupee a week, more often to twelve annas. Yet they lived so frugally on millet (a small grain called moth) that they generally had a good few silver rupees to take home, tied up in the end of a dirty loin-cloth.

The names of coolies in these hills are short, such as Jugia, Munnoo, Joga, Motee, distinguished by the addition of their caste or trade, such as Lohar (iron-worker or smith)-thus Jehan Lohar corresponds with John Smith - Sunar (silversmith), Darzi (tailor). Those who called themselves mistri were masons or carpenters, and brought some very primitive tools, similar to those used probably at the building of the Tower of Babel and Noah's ark. They use an adze and a drill worked by a bow, and a saw which works when pulled towards one, and hold the wood with their toes. Barhai mistri is a master carpenter, lohar mistri, a master blacksmith. The bellows used are made of two goat-skins, connected with an iron pipe which is built into a stone hearth. They are worked by a man who sits holding the ends of the bags, one in each hand, clasping two pieces of wood which open the end to let the air in as he draws it out, and when clasped and pressed expel the air through the pipe-right hand and left alternately-into the hearth where the charcoal fire burns. The anvil is a large stone, and with hammer and tongs very fair work is done.

Then there were the lime burners, timber workers, and 
masons ( $r a j$ mistri), not of the Dotial race, but men of the hills generally. The Kumaonis are mostly Hindus, and belong to a mild, hard-working, agricultural race, speaking a Hindi dialect. They are of a Semitic cast of feature, not like the Dotials, who are of a semi-Tartar race like the Gurkhas, speaking a Nepali dialect, have Chineselike slit eyes and sturdy muscular limbs, and are a more warlike people. Kumaon had been conquered by the Gurkhas before it came under British rule, but its people were not dispossessed of the land, which is everywhere terraced and cultivated up to the tops of the lower hills.

The masons were very clever at dressing and quarrying stones, and building them into the walls and buttresses of bridges which had to be thrown across mountain torrents and ravines. The mortar was made by attendant coolies, and the fitting and jointing of the stones was very neatly done in courses, and sometimes in cyclopean pattern, the stones being redressed when in position with stone adze-like hammers. There were timber fellers, who cut down the tall straight sal trees which grow in the forest, a very heavy and straight-grained timber, darker in colour but not unlike teak in the grain. Sal (Shorea robusta) grows all over the Bhabar, or foot-hills above the Terai, and up to 3,000 feet elevation. It was cut into great beams by men with adzes and whip-saws, who worked in the forest. These beams were used in constructing strong bridges on the principle of strut-and-tie girders, on which sal planks were laid for the roadway; piers 25 feet wide and buttresses were built where required on the foundations of great rock boulders, which were found in the river-beds, or resting on the solid waterworn rock, mostly red sandstone. There were twenty or more streams to be bridged over, of various sizes, from 20 feet to one of roo feet, besides innumerable culverts in ravines where water flowed. 


\section{CHAPTER III}

\section{TIGER-HAUNTED JUNGLES}

'Motee Pudhan' was the headman, or pudhan, of Juli village, tall and lithe in body and limb. His handsome, well-cut features, dark expressive eyes, and small head, showed him to be of a higher caste. Motee signifies 'pearl.' He was not ill-named, being an honourable, truthful, and well-bred native. He was fairly prosperous, having a well-built stone house roofed with flags, and placed on the sunny side of the hill among his terraced lands, with sheds for his cattle; having also quite a large family growing up around him, and two very hard-working wives. He always got his barley or wheat sowed in good time, after the rice and millet crop had been cleared away, and had a very good return of corn, grown on his welltilled land, and reaped in March and early April ; when it would again get ploughed by oxen and a wooden plough, and prepared for the sowing of rice, to be shortly flooded with pure running water led from the mountain stream close by. Then the women and young people would tread in and thin out the green rice plants, which grow in the mud under five or six inches of water. This crop is reaped in the rains. Rice constituted a staple food of the natives, along with wheaten flour made into chapatis, or thin unleavened cakes, with ghee or clarified butter. There were many cows belonging to the villagers, 
very useful white and gray cattle with beautiful fine shiny coats and humps on the withers, black noses, and large black eyes. They are herded in the jungle by gualas, who take the whole village stock out daily to graze, and drive, or rather call, them home at night. Many have bells made of hard wood tied to their necks, which can be heard at some distance. Tigers know the sound of the cattle bells far too well, but without bells the cattle would be lost in the dense forest.

The head-quarters of the lower section of the road which ran through Motee's village were on his land, and several acres of his terraced fields were occupied by tents and chappars (grass huts) for the native staff. Yet his temper was never disturbed by the devastation of his land, for which an equitable compensation was given him. And in his cleanest white, hand-woven cotton chapkan, with a sheet for keeping himself warm, and a neat skull-cap, Motee would often present himself at the tent door to pay a friendly visit, bringing always a bunch of ripe plantains or some very fine oranges or pommeloes.* His greatest trouble was the constant terror of the tigers which frequented the dense jungles all round his village. His often repeated prayers to be delivered from their ravages were most earnest. And no wonder. He had seen, when a boy, his father struck down and carried off by a tiger, and not long afterwards his mother was similarly treated. Therefore the presence of a sahib with guns, and a crowd of workers on the road and blasting the rocks, was to him and his family and the other villagers rather a source of relief and a protection. They could now till their land with comparative safety, and the cattle returned home to be milked with whole skins;

* Officials are permitted by Government order to accept an offering of fruit from natives. 
and his wives counted on rearing a good proportion of the calves and laying in a stock of ghee to be sold at the Naini Tal bazaar, and having plenty of dhai, or thick milk, for the $b a b a l o g$ to drink. Still, there came reports from the neighbouring villages of a terrible manswag, or man-eater, who frequented the hills around and carried off occasionally a solitary woman or old man, who had ventured alone to cut grass in the jungle.

Motee had gone one day early in April to the bazaar on business. His wives were busy, one at home, the other with a sickle cutting the ripe barley in a field close to my camp, little suspecting that danger might lurk in the neighbourhood of so much life and activity. There was one patch of yellow barley, heavy with full grain, still to be cut on a terrace just round the spur of the hillside, beyond which flowed a clear mountain stream, babbling among great rounded rocks and over-arched by dark sal trees. Creepers twined in graceful festoons from tree to tree over the torrent, and the sun's bright rays scarcely penetrated into the deep shade below. Birds innumerable twittered and frisked from branch to branch, their brilliant plumage glancing in the sun. The paradise bird with long fluttering tail, the golden oriole calling with its plaintive whistle, and green parakeets with plumcoloured heads picked at the little figs of the pipal, while troops of jungle fowl like game bantams scuttled among the tree stems. All was peaceful and bright. Luckmee, the young wife, was happy at her nearly finished work, rejoicing that Motee would be pleased on his return to find the corn all cut. She grasped the standing corn with one hand, drawing the sickle to cut, stooping, near where a huge rock, all overgrown with ferns and mosses, lay close to the tangled thicket. Lying flat among the ferns, and quite invisible to the quickest eye, the man- 
eater crouched ready for the spring, and with a sudden bound he struck Luckmee's head with his heavy paw, fracturing the poor skull with the force of the blow, and with another bound carried her off into the ravine below.

Some grass-cutters returning to the camp with $d \imath b$ grass for the horses had heard a scream, and seeing the red sari or head-veil left in the field where Luckmee had lately been working, rushed in terror to the tent, crying that the tiger had carried off a woman. Seizing guns and rifles, always kept loaded, and accompanied by some chaprasis and a brave Dotial gun-bearer, it did not take many minutes to be on the spot. There lay the sickle and a handful of corn, and, alas! a pool of blood and brains; there were the fresh marks of the great claws of the tiger's hind-legs where he landed from the rock, and his tracks, all stained with warm blood, led to the edge of the forest and down into the ravine. Following through the dense jungle over moss-grown rocks and among tangled elephant-creepers, the track was easily visible. The spaniels, Ruby and Flora, who had rushed ahead, soon returned yelping, and skulked to their master's heels. At last the dead body was found by the stream, terribly mangled and partly devoured. The tiger, however, was not to be seen. Tigers seem to have an extraordinary power of rendering themselves invisible, and hiding in thickets where other animals can easily be seen. There was no chance of beating him out, as there was nothing but forest, almost impenetrable, for miles up the mountain-side to its summit, and no paths to get there. The only thing to do was to sit still on a rock and wait for him to return to his interrupted meal, sending all the noisy followers back to camp. So clever was this man-eating tiger from having been fired at by shikaris in trees waiting over a kill, that he never came 
back. Waiting from noon till dusk produced no result. The villagers at last assembled, and came in a body to perform the last funereal obsequies, and carried away the mangled remains on a charpai to the river-side, where the burning-ghat was.

Next morning at dawn another search was made through the forest in hopes that the tiger might be hanging about. Motee's other wife was there to complete the cutting of the corn. On being asked if she was not afraid to come there by herself, her reply was that Motee had not yet returned home, and that if it was not cut he would not be pleased. It was the will of God if the tiger should come, and the corn was ripe. She was as good a bait to sit over as a buffalo calf, so there was nothing better to do than to sit concealed in the thick foliage of a large mango tree which stood opposite the rock, with a couple of rifles ready in case the tiger should choose to repeat his yesterday's performance. Nothing however came, and on Motee's return, if he had to bewail the loss of his ill-fated wife, he had the satisfaction of having his corn cut before it was over-ripe.

This tiger was not so easily got at, and for three years he had been the terror of all the villages around, stretching from near the Patli Dun westward to near where the Ram Ganga issued from the hills into the Terai eastward. The reports sent in to the Deputy-Commissioner showed that seldom a week passed without one or two deaths attributed to the Juli tiger, and that when he had carried off a woman or solitary man in one village, he took himself off at once, and was next heard of perhaps ten or twenty miles away. The Commissioner had several times sent a dozen Gurkha soldiers from the regiment at Almora, who remained for some months watching to try and shoot the man-eater, but without result; and one 
hundred rupees reward was offered for his skin. The story goes that this tiger was the son of a previous maneating tigress which had been shot some years before by the Gurkhas. She had been for years the terror of the Juli road, and many $d a k$ runners who carried the postbags from Naini Tal to the foot of the hills had been carried off. The Commissioner then ordered two dak runners to be employed, armed with sword and pistol; yet on one occasion the tiger sprang upon the leading man who carried the bag, and was only beaten off with great difficulty by his plucky companion, who carried his bhai to the next chauki on his back. The poor man was badly mauled, and the tiger's teeth-marks were through an official envelope delivered next morning to the Commissioner. One after another four brothers lost their lives. Their old mother, who had lost her last son, the support of her latter years, took up her abode under a rock close to the road. She remained there for months. Many travellers to Naini Tal saw her, and she stated that all her sons' souls having now gone into tigers, she would not be happy unless hers also went the same way, and she prayed for a release from her lonely existence by a similar death. One morning the passers-by missed the old woman from her accustomed post. It was a lovely spot-a dense, cool, shady dell with steep rocky sides. The old woman sat always on a ledge of rock sheltered by overhanging blocks, her little fire burning when she cooked her daily meal of rice or boiled millet, her covering a single blanket. Everyone passing knew her, and many had given her pice. The Gurkhas going there soon found the body in the jungle close by, freshly killed and only slightly mauled. The blood had been sucked from the neck in the way usual with tigers when they kill an animal. The Gurkhas made two 'machans,' or nests in trees, in 
different places, one being over the body, sat there all day, and shot the old Juli tigress at evening. This had been some years previous to the time of this narrative, and now the man-eating family was represented by a son of the old tigress.

To describe the death of this tiger will now be attempted, though it was not till some time later. It was the hottest season of the year I864, just before the breaking of the rains. There is something very fascinating and almost weird in the appearance of the dense tropical jungle in the hot season in June. The vegetation is all so parched and dry that the leaves rattle on the trees, when blown by the fiery blasts which sweep along the arid surface of the plains. The north-east hot winds are deflected by the upward currents, which by day are drawn by the heat of the sun up the valleys, to return at night in a downward direction. The natives in their picturesque language call this the Rani ka pankha (the Princess's fan). Most of the trees which, though evergreen, change their leaves yearly, are dropping the last year's crop about now, and appear almost bare, their bark often shiny and polished like naked limbs of a pink and yellow colour. The gorgeous flowers of the forest trees -some, as the semal,* or cotton tree, scarlet, like huge water-lilies, some orange, like the dhak-fringe the leafless stems and branches. The forest fires have made a final sweep up of all the dry grass and herbage, and the soil is black and smells of burning. The air is dense and heavy, and the hot wind ceases to blow, till at last all nature seems to collapse under the overpowering furnace-like stillness and heat. The sun seems fixed straight overhead, hanging like a crimson-red globe ready to drop on to the doomed earth. There are no clouds, but the air 
is so thick with smoke and dust that it seems to smother all life; and the sun no longer shines dazzling, but can be stared at with open eyes. The ground and rocks are too hot to touch, and the feet are scorched and blistered by the baked and deeply cracked soil. There comes a whistling sound in the air, which presages the coming monsoon, and small whirlwinds sweep up dust and leaves in pillars like devils at play. The forest, were it not for the oppressive temperature, looks almost winter-like ; and all birds and animals are silent and lie hidden in the thickest lairs, save where a clear cool mountain stream, reduced to a mere trickle, gurgles over rocks in deepest ravines, where the bright shiny-leaved jamun* trees, and the dark saj and sal form deep shade, and overhanging precipices tower overhead in lonely valleys cut deeply in the mountain-side. Here the hot-weather bird may be heard with plaintive, reiterated note, rising in hasty tones to a frantic screech, 'Brain fever! brain fever! brain fever!'

In such secluded glens the tiger sleeps all day, lying half immersed in the sand by some pool where the clear green water trickles from the rocks above, and forms a deep cool bath, fit abode for sylvan nymphs. Here he can escape from the pestering flies, and the foot of man does not disturb such solitudes at this season of the year. Towards evening or at early dawn, if hunger obliges him to leave his chosen glen, the tiger stalks through the more open forest where the sambur deer or the few remaining cattle feed; and with a swift bound he plants his great claws between the shoulders of his victim, which, rushing frantically forward, soon stumbles and falls under the weight of the greatest feline. Then he regales himself on the blood sucked from the jugular veins, and devours

\footnotetext{
* Syzygium jambolanum.
} 
the still quivering flesh from the quarters, while its companions flee in terror, scattered in all directions. The poor village guala swarms up the nearest tree, and shouts for aid in vain, trying to scare the enemy from his frightened herds.

$\mathrm{He}$ is a wasteful beast, a tiger, often killing two or three out of a drove of cattle within a space of fifty yards. But if he has once got the taste of human flesh he gets too lazy to strike the big cattle, and prefers a smaller victim more easily slain and tasty, and light enough to carry off as a cat does a mouse. Such a one was the son of the old Juli tigress. He preferred a man, or, better still, a woman, but he would take a calf if one came handy to him, and if he was hungry, which he generally was after a three days' roaming. There lived near Juli, high up on the first hills, a villager of Motee's kin, called Jussoo. He was a son of the pudhan of that village, and a noted shikari, a man skilled in all woodcraft, who knew how to trap or snare all animals of the jungle; could take the kalij pheasant and the soft whistling peura partridge* in his snares, with lines of horsehair nooses set cunningly near the drinking pools. He could trap the kakur or barking deer, and even a bear might be taken in his snare, fastened to a sapling which had sprung back and tightened on its paw. $\dagger$ He could set great beams weighted with rocks to fall on an unwary tiger; but a gun was not much in his line, and, indeed, he had no license to carry one ; and he did not believe much in a matchlock, a long clumsy thing which takes a lot of coaxing to let it off and then shoots very badly. He had, however, great faith in the sahib's double-barrelled Westley-Richards rifle, which

* Arboricola rufogularis.

$\dagger$ Strange to say, a bear will eat his own paw off before he will cut the thong. 
had knocked over many a kakur and brought the big jerow or red deer to the ground, clean shot behind the shoulder, at 200 yards, and had won rifle contest prizes at Naini Tal shooting matches against all the North-West Provinces. Jussoo was a marvellous tracker, and could follow the khoj (track) over every ground and tell how long ago the beast had passed. He knew well the 'pug' of the Juli tiger, which had a peculiar twist of one claw. By his assistance many a head of big game had been brought to bay, and much jungle lore had been picked up by conversing with him and watching his silent, stealthy ways. He never failed to bring information when his enemy the manswag came into the valleys above Juli village; and saw to the tying out of a buffalo calf in a likely place.

Work for the year having ended before the rains set in, and the sahib having taken up his residence at Naini Tal, Jussoo appeared one day at the bungalow door with a face of excitement, requesting an interview. The result was a hurried discarding of the smart society get-up which the gay season made necessary, and a rapid start in the lightest marching order and jungle costume into camp. A smart dun-coloured hill pony, that could go downhill like a goat, shambling along in a sort of rapid run-not a trot or a walk - of the breed called Bhotia, or gunt, soon brought the eager tiger-hunter down the nine miles of almost precipitous descent by the winding pag dandi (footpath) to Juli. Every thousand feet of lower elevation meant degrees of higher temperature, the rise being from about $70^{\circ}$ to $120^{\circ}$.

Next morning a buffalo calf was procured from the village and tied out in a secluded valley right up in the heart of the most jungly recesses of the forest under the Juli range. Jussoo, whose intimate knowledge of the 
haunts and habits of the tiger led him to this spot, declared that the tiger was here, lying in some cave under the rocks. He pointed out the perfectly fresh tracks on the sand of the stream bed. He declared he had performed a sacrifice to the devta or deity who haunted that jungle, and the omens had been good, so that he felt certain that this time the sahib would kill the man-eater; that fortune, which had not befriended us in many previous attempts, was now turned in our favour, and the fairies were propitious.

There is something weird and uncanny in the tigerfrequented jungle, where not a sound is heard, and you pass along seeing nothing, and yet knowing that he is lurking close by, perhaps looking at you, yet invisible, but his presence assured by the great impressions on the sand, once seen never to be forgotten, into which the water is fast oozing. This was a lovely glen with lofty walls of rock rising high on one side, over-arched by great trees of dark evergreen foliage, with sloping bank rising opposite from the stream, clad with bushes of the beri, or prickly thorn, in dense brakes topped by lightgreen feathery mimosa, wild lemons, and other tropical trees. The gay yellow-flowered cassia,* and various creepers hanging in luxuriant wildness, presented a picture of beauty and harmony like a huge conservatory of the rarest plants, orchids of various forms clinging to the rugged stems, the silence only broken by the murmur of the pellucid green water over the fern-clad rocks, and the shade of the huge overhanging mountain hiding the almost vertical sun. Having chosen an open space under some great trees of wild mango, Jussoo proceeded to tie up a buffalo calf which his boy had been ordered to lead to the spot. There was a suitable fork in a thick leafy * Cassia fistula. 
tree for making the machan, which was done by tying some branches crosswise, and weaving a screen of boughs at a height of some ten feet from the ground. Above the glen there towered a rock of gray sandstone in view of the spot, whence the boy was instructed to look down at evening time and again at dawn, to report as to the safety of the calf. A cow-bell, made of hard wood hollowed out with a tongue inside, was fastened round the patient buffalo's neck, and he was left to his certain fate. These preparations made, there was nothing to do but to return to camp and wait patiently for news.

Patience is a virtue important if the shikari will be successful; and other necessary qualities are foresight, silence, the faculty of observing every indication of the tiger's presence, and cunning to outwit so stealthy and guileful an animal as the lord of the jungle. Nightfall came without news, and the darkness and stillness of the sweltering atmosphere was oppressive. Sleep was hard to woo, and the ears of the watchful and excited Jussoo were ever strained to catch the distant sounds and night noises of the jungle. Twice the hollow, unmistakable yawning call of the tiger came on the sultry air. Whence, no one could tell, but sleep was impossible till near daybreak, when the wearied eyes closed for a little, and a cool breeze passed through the tent.

Jussoo's shiny face peeped into the small sholdarry to give the news that the calf had been killed at earliest dawn. A cup of hot tea and a rapid toilet did not take long, and fresh loading was put into the two rifles, one a single 8-bore, the other a Westley-Richards double I6-bore, with which the rifle prize had been won. Now came the critical time, when the machan had to be mounted without the tiger knowing, as, if he heard people near his kill climbing trees or cutting sticks, he 
would certainly suspect a trap and not return any more. Jussoo, carrying some eatables in a basket, went up the path by the stream, making the peculiar call which gualas always make to lead their cattle. The tree was silently swarmed and rifles handed up, and Jussoo went away quickly by another path, still calling to his cattle, till his voice died away in the far distance. The day was long and sultry, and the limbs wearied with the constrained attitude. Not a cough or a move could be indulged in, nor yet tobacco if success was to be secured. Luckily, for a wonder, the flies even were too sleepy and overpowered by the heat to trouble much, though some did buzz persistently about one's nose, and could not be beaten off, as the movement of the hand would surely betray one's whereabouts. Nothing but the hope of securing the man-eater which had killed two or three hundred human beings, and had evaded well-laid plans already many times, and escaped from the snares of the clever and plucky Gurkhas for three seasons, could have induced a comfort-loving mortal to endure to the end. Twice had he escaped when whole nights had been spent on the watch for this terrible destroyer of families, this scourge of mankind. Once he had come when the moon was gone down, and the crunching of the bones was the uncertain mark to fire at. Once, in the winter, it had snowed all night, and in a tree it was cold. It was not cold now, and patience was the only virtue to be hung for.

Well, patience was rewarded, for about three o'clock in the afternoon, after sleep had nearly come unbidden, with the risk of a dangerous fall (finger on trigger and two full-cocked rifles balanced on shaky boughs), there came to the ear faint, uncertain indications that something was on foot. About three o'clock is the time when 
animals awake from their siesta and stretch themselves and drink. A sudden start and rattle of stones in the bed of the stream revealed that a sambur stag had come to the water and had scented the tiger. He fled up the glen as if the fiend was behind him, throwing back his velvety horns to avoid the boughs. Then a slight crackle of a dead leaf was detected, followed by a scraping, as of claws on a tree in another direction. All round in a circle the tiger seemed to have stalked, to scent for danger before approaching his prey. The intense excitement of those hours, which seemed moments and the moments hours, have left an impression which cannot be effaced, and every incident will come back to the writer's memory, as if it were happening now while the story is being written. How the tiger's presence was felt before he was heard, and heard before he was seen, could only be realized by having had the experience.

When the tiger's great yellow flanks became visible as he moved on through the thicket, it was such a slow, gliding motion that were it not for the black stripes the eye would fail to catch it, and the ear could detect no actual sound. When all object for concealment ceased, and he had satisfied himself that there was no trap, he walked out into the open proudly, with the air of a monarch. But a cruel, ravenous monarch. Terrible in his nature, he seized the poor dead calf and shook it as a cat does a mouse, snarling fiercely in his wrath, and commenced to devour the hind-quarters, crouching low on his belly and crunching savagely, his great yellow eyes glaring with savage satisfaction. His comfortable meal was his last, and three shots finished his guilty career. The first behind the shoulder, when he roared a mighty roar and bit the dust, breaking his claws on the rocks; the second and third, from the double rifle, were 
in the neck and head, as a precaution against his getting up again, as tigers have immense vitality, and have been known to come to again after lying apparently dead, and just kill the shikari who ventures too near, upsetting all his calculations. One must feel an awful fool if a tiger escapes for want of a second barrel, and it is a very common story indeed.

It had been a long wait, but caution is the second most important virtue in tiger hunting. A heavy boot, thrown after a sufficient time had elapsed, failing to make him move, it was safe to come down from the tree, and soon the shouts of Jussoo from the valley below, in response to a call agreed upon signalling success, were heard coming nearer. Before half an hour fully twenty natives appeared from the jungle paths, and the tiger was inspected with many 'Wah wahs!' and 'Ram rams!' They almost worshipped the slayer of the terrible manswag as the deliverer of their homes and families from a long-experienced dread. The tiger was carried in triumph to the camp, and the procession along the road received accessions from goodness knows where, as the villages are scattered and some way off on the spurs of the hills. But they had all known of the result by signals from Jussoo, and great was the joy in the whole district. The tiger was a fair-sized male, 9 feet 6 inches long, and had the crooked claw of which Jussoo knew the track. His whiskers were pulled and taken for charms, and next day, when the skin was taken off, his flesh was taken away and divided among the villagers, or sold in the bazaar at Naini Tal, as a charm against tigers, or a medicine to cure deficient nervous energy, and other diseases which would not yield to the treatment of the best hakims. The return to Naini Tal was one of great satisfaction, as the cool climate and congratulations of friends were 
properly appreciated after the sweltering heat below. The skin and head, tied to a pole, were borne by shouting natives along the Mall and through the bazaar, amid great rejoicing at the death of the much dreaded maneater. 


\section{CHAPTER IV}

\section{FOREST SURVEYING}

AFTER a time I received from the Lieutenant-Governor the appointment of Forest Surveyor for the North-West Provinces.

The duties of that office were to visit in order the several localities where forests exist, and survey and map out their boundaries and areas, giving careful details of the timber growing in them, and a report as to the quality of the timber, and character of the land it grows on. The scale of the maps was to be one inch to the mile, and schedules were attached to each sheet of twelve miles square, giving average of first, second, third, and fourth class trees per acre growing in the jungle, of the sorts which were valuable as timber of construction, omitting the rest of the trees as not of any economic value.

The hill forests of Kumaon extend over an area of I5,000 square miles of actual forest, situated all over the district, which is about I50 miles long and Ioo broad, bounded on the south-west by the plains of the Bhabar and on the north-east by the snowy summits of the Himalayas and Tibet, on the south-east by Nepal, and on the north-west by the Alaknanda, a principal branch of the Ganges. This was a country of considerable extent, almost as large as Switzerland, and containing half a dozen of the highest mountains in the world; the celebrated Gangotri, or sources of the Ganges, the most sacred 
place in Hindu mythology, with innumerable minor ranges covered with almost unexplored forest; precipices of fearful height; enormous glaciers, deep valleys, and rushing mighty rivers. There was a peaceable, wellgoverned population, not too numerous; things of interest on every side; and, last but not least, game of all sorts in plenty. Here was a prospect of independent work, entirely suited to the taste of a lover of the forests and the wild beauties of nature. It is generally troublesome for private individuals to get very far in the exploration of the higher hills, owing to the difficulties of transport. Provisions and camp equipage have to be carried on the backs or heads of coolies, who belong to the scattered villages, and have to be taken from their work of cultivation, which they do not like to leave. But they are bound by treaty to supply porters from every village for civil officers travelling on official work, and come more or less cheerfully. No shirking could be allowed to prevent the surmounting of the most unfrequented hills, and every valley and pathless ridge had to be traversed somehow. The instructions were given by the secretary of the North-West Provinces Government, Public Works Department, to the Forest Surveyor every six months, and the report and maps had to be sent in through the Commissioner. So that there was no official interference in the course of the season's operations. Lieutenant-Colonel Drummond, R.E., was a kind and approving head of his department.

The climate was always excellent, as one could choose the elevation according to the season of the year, the highest hills in the hot weather, while in the cold there was work in the plains. Naini Tal was the head-quarters during the rains, when the mapping was done. The province of Kumaon was the first undertaken. 
It may be premised that the forest survey did not include the general survey of the country. This had already been well performed by the trigonometrical survey officers of the Royal Engineers, whose work had been published by Government, and very excellent maps existed, showing the exact positions of all the highest peaks and minor points of all the ridges of hills where cairns of stone had been erected; and the courses of all the rivers and streams were fairly well mapped out. These maps were the basis of the Forest Survey. The sheets of twelve miles by twelve were taken on an enlarged scale from the map, and carried in the form of a book, upon which the positions of ridges and spurs were drawn in with the assistance of the prismatic compass and protractor. The forests were delineated, and areas calculated where timber grows. The average was taken, in each forest, of the number of trees per acre, by running a line through the forest with a 66-foot chain. The contents of each square chain were counted by the operators. It may be stated that, as the result of many observations, the general average of a measurable forest was thirty trees per acre, of which about seven were first class or over 6 feet in girth ; and usually there was an equal proportion of second and third class trees of 4 feet and 2 feet girth, and a growth of fourth class trees and saplings under 2 feet, fairly scattered through the forest, besides innumerable seedlings not counted. This was the normal condition of the natural forest, where, as the hoary and mature trees fell from storm or old age, there were generally younger ones of all ages ready to take the places of the dead ones. Thus in natural course the forest, like the population of mankind, renews itself gradually.

One seldom sees here, as in America, whole forests devastated by fire, since, owing to the copious rainfall, 
commencing in the hottest season, the growing trees will not burn. In India the dry grass is burnt on the lower hills every year in November and up to June, but the trees, except a few dead or fallen ones, resist the fire and scarcely suffer at all. For the same reason the Indian forests scarcely ever present the uniform appearance of American forests, or of artificially formed plantations, where all the trees are of the same age and height, crowded together like a field of corn.

Where the soil is deep, on the less precipitous slopes and dells, one sees in the Himalayas magnificent specimens of giant patriarchs of immense age, measuring 30 and 40 feet in girth, with stems like pillars towering to the skies; especially among the deodars, which attain a height of 200 feet and more, surrounded by their progeny of all ages grouped together in the most picturesque manner. No wonder that the natives reverence this noble cedar, the prototype of the cedar of Lebanon and the Atlas, as the sacred tree of God. Its timber is most durable and sweet-scented, and its grain so straight that in some places they split the great logs into boards to construct their temples, and into shingles for roofing, which stand the changes of climate for centuries without any sign of decay. The forests of Kumaon contain also four different oaks, chestnuts, sycamores, horse-chestnuts, and many representatives of the European well known and valuable timbers. The Pinus excelsa* grows to a great size with its light blue feathery spines. The silver fir $\dagger$ grows on the northern slopes at an elevation of 12,000 feet, and forms a dark and bristling jungle, reminding one of the Black Forest of Germany; but the size and age of

* Native name, 'Dolchella': silver red pine, Pinus excelsa.

$\dagger$ 'Raga': silver fir, two species, Picea Webbiana and Picea Pindrow. 
the mature trees, and height of the stems, are greater generally in India. There are forests of the spruce,* in

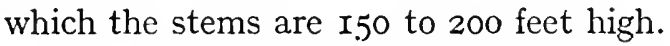

On the lower and hotter slopes of the foot hills, up to 7,000 feet, the long-leaved pines, $\uparrow$ with red stems and spines I2 inches long in light-green tufts, are more abundant, reminding one of Scotch firs exaggerated in size and monopolizing the soil. In situations where the rock comes to the surface, this pine will take root and hold on to the cliffs in a wonderful manner, every stem being twisted like a corkscrew, all in the same direction, left to right, and presenting a most weird appearance. The cypress tribe is represented in some ranges nearer to Nepal by the very beautiful and towering Cupressus torulosa. $\ddagger$ It grows only on the sunny slopes over 7,000 feet, in isolated localities, one of which is at Naini Tal, where some noble trees were growing under China Pahar r5o feet high, with clean stems to near the top. I measured an old cypress at the back of China 37 feet in girth, and I have measured several deodars of 40 feet. These are the principal timber trees which are included in the list of those reserved by the Forest Department as of value for timber of construction. The jungles, however, contain hundreds of other beautiful and excellent hard-wood trees, as well as various species of oaks and sycamores, walnut, and the elm-like Celtis austraica, rhododendrons (of which I have measured stems I5 feet in girth of various kinds), besides, lower down, the tropical sal (Shorea robusta) and saj; while high up near the snows are the familiar birch and juniper. Box is also found of good thickness in some of the hills. In some

\footnotetext{
* 'Kurchella': drooping spruce, Abies Simithiana.

+ 'Chir': long-leaved pine, Pinus longifolia.

† Native name, 'Surai.'
} 
regions the finest forests are so remote from roads that their value is much diminished. The object of the survey was to determine the position of all forests, and ascertain what extent existed within reasonable distance of land or water carriage. If the river flowing down the adjoining valley were large enough to float down logs to the plains, it might then be feasible to construct roads or timber slides to transport the logs to the water, as in Switzerland and the Black Forest. This had been tried in the deodar forests of the Punjab, mostly in territory belonging to rajahs. But the great roaring torrents of the Sutlej and its tributaries, rushing in the rainy season through rocky defiles, had been found so destructive to the timber floated down that much loss was occasioned. All such features had to be reported on, and sites selected for roads and saw-mills.

I have sketched the principal features of the work of forest surveying, and will now proceed with the narrative of events, and describe by the way the human inhabitants and game animals of the hill forests. 


\section{CHAPTER V}

\section{CAMPS IN THE UPPER FORESTS}

THE sacred Ganges, celebrated in earliest times and sung by poets, rises in Garhwal. Its principal branches are the Bhagirathi and Alaknanda, which issue, under the latter name, from the hills at Hardwar, a noble and mighty river, swelled in the monsoon to a huge torrent. In the dry season a clear stream; in the hot weather, fed by the melting snow and glaciers, a cold, white, turbid flood.

The most sacred place in Hindu mythology is Badrinath, where is the head source of Ganga in the group of lofty peaks known as Gangotri, in Garhwal. The adjoining group of the sacred Nanda is in Kumaon, separated only by the river Alaknanda. Here are five lofty peaks rivalling the four of Badrinath, all over 22,000 feet high, the giant summit of Nanda Devi, 25,749 feet, dominating the group.

It was to survey and explore the slopes of this vast labyrinth of mountains, intersected by valleys of immense depth and filled with huge glaciers, that the present march was undertaken, to map out its forests and report on its capabilities. Following upwards the course of the great river flowing with many windings, one traverses the route of the pilgrims who come up from Hardwar, passing the celebrated stations of prayer which commence at Benares. These are Deoprayag, Nandprayag, Karnprayag, Vishnu- 
prayag, and, highest and most sacred of all, Badrinath and the Cow's Mouth, where issues the sacred stream from its glacier source. One sees thousands of pilgrims, who have come on foot from all parts of India to participate in the benefits which are promised them hereafter. It is a strange and pitiable sight, that great throng of poor, starved and worn-out people struggling on with scarcely a rag to cover their skeleton forms, firm in their ancient faith, the maimed and sick, old and even blind, feeling their weary way along a well-worn but most difficult path, which follows the course of the raging torrent, sometimes on the flats below by the river, but more frequently terraced along the face of lofty precipices I,000 feet above the stream. Many die on the journey up, or fall into the icy river, where their miseries are ended and their future is assured. Some, wealthier or fatter, incapable of traversing the dangerous path, may be seen borne in kiltas or big baskets on the backs of sturdy Garhwalis. If ever they reach the Cow's Mouth, where the Ganges issues from a cavern, the cold of the snow and glacier is pretty sure to produce a deadly chill, which kills many of the poor wretches, only used to the fiery heats of the plains.

This was the route followed as far as Karnprayag, striking upwards so as to avoid the disagreeables of the pilgrims' vicinity, often infected with cholera and plague. There was no question that the upper path over the passes of Pilkhunta was preferable, though it led some distance over snow, and involved an ascent of thousands of feet.

In the month of May the sun had fearful power in the valleys, and produced fevers of the worst kind. To follow the ridges, and remain at an elevation of 9,000 feet and upwards, was desirable but difficult to accomplish, as there were not always routes passable for coolies carry- 
ing heavy loads, or ponies even without loads. Nor were there always villages where coolies could be got. The camp was therefore pitched near the highest village, and excursions made in the lightest marching order to the neighbouring heights. The baggage consisted of a small sholdarry tent, 6 feet square, containing a camp bed, made like a charpai with poles inserted into the four legs, and a canvas bag open at both ends. A cross-legged table and bamboo chair, copper chilamchi basin and two kiltas, or oval covered baskets, cased in deerskin with the hair on, containing change of clothing, books, and other articles. These were in charge of a man who came from the Kangra valley, Taiz Singh by name, a tall, active Rajput with close-fitting, white garments, and many yards of spotless white muslin folded round the head. He was a faithful, honest, and capable servant, who could be trusted to pitch the tent in a clean and shady spot, and have his master's shirts and socks always folded and ready, and to attend on him to perfection, unpacking and repacking everything with regular exactness, and having soap and candles ready as required. Taiz Singh was a gentleman in his manners and ideas, a tall, handsome, black-eyed, dark-skinned hill-man, with shiny black curls appearing under his puggaree, and beard and moustache turned upwards at each side in the most dandy fashion. He carried the sahib's sword, a big one in a steel scabbard, always at his side-a symbol of office. Taiz Singh inspired respect among the villagers, and was withal gentle and polite, but brave as a lion, as his name ('Swift Lion ') implied. He followed me in every climate and country, in plains and hills, and seemed to be attached from feelings of affection. Sirdar Khan, the Mussulman khansamah, was in charge of the kitchen arrangements, and had a small tent for cooking. He had two kiltas stored with 
provisions-tinned soups, tea, sugar, rice, and jam-with sundry spices and condiments for making curry. Flour and ghee were procured at the villages. There was a Mussulman bheesty, or water-carrier, with his goatskin masak, who assisted in the bobachi khana, or kitchen. Sirdar Khan could with a few copper degchis, or round vessels, and on a fire of sticks between two stones, turn out a quite excellent repast; and his chapatis, or thin cakes, were like crisp bubbles of thin pastry.

There was a little flock of sheep and goats who marched with the camp, to supply occasional mutton and fresh milk for the tea, which was the universal beverage. There was one old she-goat which led the flock: she would wait watching, when the tent was struck, for the signal to march, when, bleating to call the flock, she would start away along the path quite gaily, followed by the rest. There were some big, tall, shaggy he-goats, which carried each a pair of bags made like a saddle of strong goat's hair, containing some stores, such as rice. The two hill ponies were led by their syces, one a 'Bokhara' called Jacob, a beautiful black, about fourteen hands, with long wavy tail and mane combed out, his silky coat shining like a mirror. The other was a gunt or Tibet pony, dun coloured, sturdy and strong, with shaggy coat and feet like iron, never requiring shoeing. They were ridden at times, and were always willing and sure-footed, and could go over rocks and precipitous ascents anywhere that a man could climb. They picked their way across the bridges, where two round tree poles formed the path across a deep ravine, or swam a rapid-flowing river where no bridge was possible.

Then there was the Forest daftar or survey-staff, consisting of a native surveyor, Damoodur by name, and an assistant, who acted also as munshis. They kept the 
accounts, drew out the monthly pay-bills, and paid the coolies, besides taking their share of plotting-in, and counting lines of timber through the forest with the chain. There were six chaprasis with red belts and brass plates labelled 'Forest Department,' symbols of office, whose business was to carry the $d a k$ and bring out bags of rupees monthly from the nearest tahsil (treasury); to go on ahead and obtain supplies for the camp from the villages on a parvana, or authority, from the Deputy-Commissioner, ordering every pudhan, or headman of the village, to furnish supplies and coolies as porters. The coolies received four annas a day, or stage, each man. This was double the old rate of pay for a coolie, an advantage which the good and much praised Commissioner Sahib had thought right to procure from the Government, owing to the scarcity of men, and the hardships often inflicted by frequent requisitions and the severity of the work. Each coolie was apportioned a load of thirty sers, or sixty pounds, which was a heavy burden to carry ten or twelve miles up and down precipitous paths, often scarce traversable by goats.

There was a great difference between the villagers of the lower valleys and the upper hills. The former, dressed in coarse white cotton clothing, mostly a jacket and loincloth, were wretched, poor, fever-stricken people; the latter, a fine, robust, and muscular lot, with sturdy limbs and jovial manners. They were clad in coarse homemade woollen jackets and trousers, tight below the knee, and woollen folded caps. The women wore a coloured bodice, with a gap of shiny brown skin between that and the petticoat, which was of strong woollen material. The loads were often carried by women, who bore them on their heads, or sometimes on their backs with a strap over the head. 
It was an amusing daily episode to see, when the coolies were being started, the rush that was made to secure the likeliest-looking loads, and the wrangle which ensued when they imagined one had got a lighter load than his neighbours. As care had been taken to weigh them all with a spring balance, there was little to choose between the loads. A spring balance is, however, deceptive, as it weighs quite differently at an elevation of ro,000 feet to what it does at the level of the sea. It is no wonder that the inhabitants prefer the Government of the British Raj when they recollect the oppression of previous native rulers, who used invariably to employ forced labour and pay the poor villagers nothing at all.

The direct march from the village of Pana over the Pilkhunta Pass, crossing a lofty spur of Nanda Devi, was a long and trying one. From the summit there appeared quite close northward the huge snowy triple peaks of Gori Parwat, 22,700 feet high. The snow line ended at I5,00o feet, except in the upper valleys, which were filled by snow and glacier. Below the snow line were bare rocks and grassy slopes, where the wild sheep and goats, burrhel and thar, grazed. There was then a belt of juniper and birch forest, and below these stretched for miles a thick forest of various pines, mostly spruce. This was a typical Alpine region. In the survey it is put down as Lata Forest, 38,000 acres of timber. The stems of the great spruce trees (Abies Smithiana) stand out against the rocky gorges some 200 feet in height. There were some patches of beautiful feathery cedars (Deodara). One stem measured thirty feet in girth. It seemed as if one could step across to the sunlit slopes, but between was a deep valley down miles beneath one's feet. Below could be heard the roar of the Dhauli river, a snow torrent rushing from the valley of the Niti, a well-known pass to 
Tibet. The descent lay through the extensive forest of Tapoban, extending for eighteen miles eastward, and clothing the slopes of the valley of the Rishi Ganga, a torrent-branch of the Dhauli, which comes from the glacier of Nanda Devi. This forest faced the north, and consisted of silver fir (Picea Webbiana) and Pinus excelsa. It took a week to explore this forest. It was full of game, bears, gooral, and the jerow, or great sambur deer. The underwood in these regions consists of ringal, or hill bamboo* (Arundinaria), growing so thickly that it is nearly impossible to get through it. These bamboos are very hardy, and make capital fishing-rods 30 feet long, hollow and light to handle. A long descent in the shadow of Nanda Devi, trying to the shins, brings one late and tired to Tapoban, on the Dhauli river, a camp on the route of the Bhotia traders over the Niti. Here are some hot springs near the river-bed, and a pleasant bath is obtained. It is dangerous to bathe in the snow-water, which sweeps by as white as milk from the quartz rocks of Trisul, ground fine beneath the glaciers.

Tapoban is a hot place, and there is little space for pitching a camp. An early start is made in company with a sahib who is marching up the Niti for shikar, and has already shot some gooral (chamois of the Himalayas). He has been after the thar on the heights above, but has not got any. Leaving the Dhauli river, I enter the side valley of the Rishi Ganga and encamp above the village of Rindi.

Here a guide or shikari was engaged from the village to explore the higher forests in various directions, so that a near acquaintance could be made with the great

* I have seen large clumps of this hardy bamboo growing and thriving well in the woods in Ireland, grown from seed sent home by myself. 
central cluster of snow peaks. Nanda Devi is one of the most notable mountains in these parts, and extends with its brother peaks of Nanda Kot, Moo Gobin, and Trisul over an area of ten sheets of the survey, each twelve miles square, about I,440 square miles, or 92I,600 acres. From its great masses of snow-fields the Niti, the Rishi, the Pindar, the Trisul, and other glaciers descend. That in the Milam valley on the north-east, which will be visited later on, is thirty miles long. It was impossible to take the camp up the Rishi valley, as the sides were too precipitous. The camp was therefore left at Rindi, and a start was made with three men only from the village, all well used to snow and glacier and rock climbing, and one a good shikari, Punoo by name. A description of one climb taken from my diary will be given in the next chapter. 


\section{CHAPTER VI}

\section{AMONG THE SNOW PEAKS}

The animal described in Dr. Jerdon's ' Mammals of India' as the Ther or Gharal, Hemitragus jemlaicus, is a true wild goat, here called 'thar' by the natives. He possesses true caprine characteristics, a long shaggy coat, and trigonal horns turned back, peculiar in being very short and thick. He is about the size of a Lincoln sheep, but taller, and inhabits rocks and precipices of the steepest character right at the top of the tree line, here I3,000 feet high. He is, however, partly a forest animal, not always a frequenter of open grass-covered hills, like the various wild sheep. The thar is gregarious. In the summer the females and young ones are found in herds of ten to a hundred, and the males in smaller herds, generally higher up. In the rains the old thar becomes almost solitary, lying all day in the thick timber, and appearing at early morn and evening on the grassy slopes above to graze, and again retreat to the thickets. At the end of the monsoon an old buck thar is a very big, heavy beast, very fat, almost black, and with long black hair hanging down so as almost to cover his thick legs. He is then very difficult to approach, and a noble quarry for the shikari, who must work hard to procure a specimen. The females, called by the Kumaon natives 'therina,' are more easily approached, and resemble in their habits very much the chamois of the Alps. 
The weather had been settled and hot for some time, and a good many ascents had been made with survey instruments and rifle, starting at daybreak and returning to camp at nightfall. On this occasion it was determined to ascend the great precipice which towered north of the Rishi stream, and to remain out at night in order to explore still higher ground. Provisions and a kettle and blankets were included in the impedimenta carried by a strong hill-man. The shikari, Punoo, was a tall, active native, clad in the hand-woven woollen coat and trousers and cap of natural-wool colour, similar to the colour of the rocks, usually worn by the villagers. He possessed all the qualities of the best Swiss guides, quick eyesight and an unfailing instinct as to the surmounting of crags and taking advantage of the trend of the strata and intervening grassy slopes and crevasses in the rocks, to pass upwards where the precipice appeared from below to be insurmountable. The summit was lost to view, or stood out against the deep blue sky, towering thousands of feet above the camp like a wall, almost overhanging where the vertical strata were broken off. A start was made after early tea, at about 4 a.m., in the dark. At first the sheep tracks leading to some grassy slopes were followed. The true pahari climbs with deliberate steps, never hurrying or getting out of breath, noiselessly choosing the best place for foothold on rock or grass, never detaching a loose stone which would be dangerous to those following him, balancing his weight truly as he climbs, so as to make no false steps. Light English shooting-boots well studded with nails are the best for the work for those used to boots, though some prefer grass shoes, which will not slip on rocks. The native wears grass shoes or goes barefoot. Several thousands of feet having been surmounted at about one thousand an 
hour, the tracks became less marked, and were only at times met with, formed by the game. A grassy slope was followed between two lines of strata, and ravines like chimneys were passed, where stones were apt to rattle down and had to be dodged.

Towards noon a halt was made on a ledge of rock overlooking the valley below. Breakfast being partaken of, the glasses were used to examine the hillside, and sights were taken to fix the position of the forests in view; the river was scanned descending from glaciers, a white twisting line of foam, hid in places by rocks and boulders. A black object was seen on a snow bridge. The binoculars revealed a large black bear 5,000 feet below, crossing the valley, a mere black speck on the snow and gray rocks. Tracks of therina were now numerous, and silence was necessary not to alarm the watchful sentinels of the flock now reposing in some safe position, where the upward breeze began to freshen. It was useless to stalk going upwards, as the scent would soon betray the shikari's approach. We must round the rock buttress, where the tracks of the thar and fresh droppings showed that a large flock had recently passed along to where more grazing ground existed. There were caves where the slabs of strata overhung the shaded sleeping-place of many thar. A well-worn pulpit-like rock was the sentrybox, where some old female was placed to warn the flock of danger from prowling snow leopards, white like the weather-beaten rock.

Following this narrow ledge was dangerous in places, as one slip on the polished gneiss rock would shoot the unwary cragsman over the edge to fall into the depths beneath. A stone dropped here would perhaps strike twice in a descent of 4,000 feet. The natives crossed barefoot with the utmost nonchalance, carrying rifle and instruments and their 
loads. The sahib, carrying two light bamboos, walked slowly in stockings. Two bamboos, 7 feet long each, shod with iron, are wonderfully useful at this climbing work, as they enable one to use the arms and shoulder muscles to assist the leg muscles in raising the weight upwards, and in descending the slopes they are far better than one alpenstock, enabling the pedestrian to let himself down by a series of short steps and bounds, kangaroofashion, taking the strain off the shins. They are handy also to steady the rifle when firing, being held cross-wise in one hand, while the rifle rests in the fork. Emerging from this nerve-trying passage, we found ourselves on another grassy slope trending upwards towards a narrow gorge from which no exit appeared. We rested a bit, concealed by boulders, and scanned the next walls of rock. It was well this precaution was taken, for, as Punoo had predicted, we were not far from game. The motion of an ear caught the eye, and sure enough there lay a flock of about thirty she-goats and their kids, so like the colour of the stones that it was difficult to distinguish them, even though the nearest was not go yards away. Searching for the thicker horns of the males, one or two could be distinguished lying asleep with legs doubled up; and resting the rifle on a boulder and firing across the ravine, the first shot was successful in killing a nice young fat buck, which luckily fell against a jutting rock some 20 feet below. The report, though echoing like a thunderclap, was not so alarming in a place where thunder is common and the falling of rocks an hourly occurrence. But the head of Punoo, showing in his excitement to mark the falling thar, was the signal for a rush ; and in a moment the whole flock disappeared round a jutting crag, bounding apparently into the air as if to certain destruction in the valley below. It is the most 
surprising exhibition of what seems to be miraculous to see a flock of thar with perfect ease crossing the face of precipices where apparently no foothold exists, in complete defiance of the laws of gravity, where a pair of wings should in all common reason be indispensable to avert a calamity.

Punoo now decided to explore the grass slopes visible above the ravine, and soon discovered a practicable ladder-like ascent. Steady climbing for three more hours brought us into easier ground, with a well-defined chimney-like ascent and great boulders, which were jammed where they fell from the crags above. The view was now magnificent of the great peaks of Nanda Devi, facing us at a distance which seemed like half a mile, every stone being clearly defined in the rarefied atmosphere. In reality, by the map and prismatic bearings, the summit was twelve miles away. The whole amphitheatre of mountains, all over 20,0oo feet above the sea and I4,000 above the bottom of the valley, reminded one of the Bernese Oberland from Mürren, but in more gigantic proportions, with snow and glacier extending for miles around the great bare peaks, many of them unnamed and all of them nearly inaccessible and unexplored by man.

The actual prospect of snow peaks surrounding the Rindi valley, which probably exceeds the depth of the celebrated Colorado cañon, comprises the peaks marked in the Trigonometrical Survey as No. X., to the S.IV., r5,805 feet in elevation; No. XI., 20,758, named by the hill-men Nanda Gangoti ; No. XII., 22,385; No. XIII., 22,388, named Moo Gobin ; No. XIV., Nanda Devi, 25,794. These form an amphitheatre to the south and east. The circle is completed to the north by the massive summit of Dunagiri, No. III., 23,3r7. Visible in places are also 
the summits of Nanda Kot, No. XV., 22,49I feet, and the three peaks of Trisul, all within a radius of twelve or fifteen miles. The bottoms of the valleys, where the torrents flow from the glaciers, are about 5,000 feet in elevation. The whole of their upper portions are filled up with glacier masses and vast snow slopes. The glaciers to the north are, however, more extensive than those in view.

The queen of the group, Nanda Devi, stands like the Jungfrau, high over the others, with precipitous sides. With the glasses one could see that there were great crags of white quartz on its northern face, towering perpendicularly above the snow-fields, where no snow could rest. During the heat of the day one could hear incessantly the distant roar of avalanches echoing like thunder, and the falling of rocks and the constant murmur of many torrents in the far-off distance; and yet one could see nothing in the whole circle of the amphitheatre of snow mountains to account for the noise; all seemed peacefully sleeping, basking in the brilliant sunshine. The white courses of the streams shining like a map at one's feet seemed quite close, as if a stone could be thrown on to them. That here in this solitary vastness a little speck of humanity could stand and look into the mysteries of the world was impressive.

The day began to wane as we still climbed upwards, sometimes following the paths formed by the wild animals up the grassy slopes, sometimes clinging to the crevices of the rocks overhanging the khud, and worming our way among the intricacies of broken pinnacles, where the dwarfed and weather-beaten pines were succeeded by junipers and aged birch, and where tracks of bears and snow leopards were often visible. The atmosphere became gradually colder. Fleecy white clouds began to 
gather about the hilltops. Out of the silence there came a rushing sound caused by the approach of a whirlwind, which carried along a pillar of dust and leaves wrenched from the trees, which were borne upwards into the sky, presaging a storm. Tumbling and threatening masses of clouds came up rapidly, and suddenly there was nothing to be seen but white mist. Punoo was not at a loss, but soon discovered a cave under broken rocks, where shelter could be got from the coming storm; and we proceeded to make the place shipshape for the night. Dry juniper boughs were collected, and a comfortable fragrant couch was made ready. Some snow was brought from a ravine near by to melt for water. A fire was lighted of dry sticks, and the kettle put on. Soon the storm burst, with torrents of rain changing to hail and snow, like the report of a roo-ton gun close to our ears, accompanied by a blinding flash; the lightning seemed to cleave the mountain, where we cowered crouching into the recesses of the cave. The echoes from the hills came back at intervals, as if every mountain was falling in universal chaos. The pinnacle under which we sheltered shook with a terrible vibration as the thunder rolled, and tottered as if about to topple over into the valley 7,000 feet below. The flash of the lightning soon became a continuous discharge, and the thunder one perpetual roar, quite blinding and deafening; but, strange to say, no harm was done us. The storm raged above and below. The electric fluid seemed to go right through one and pervade all space. Being on board an ironclad in action surrounded by a whole fleet could not be more deafening or more terrifying. I have experienced innumerable thunder-storms, but never one like this, so near and with such grand and impressive surroundings. Even the natives who lived in this region were senseless with fear, 
and thought their last hour had come, calling on the Hindu Trinity and the devta of this mountain to protect them.

Soon, however, the overcharged atmosphere became less electric, and the storm passed on up the valley, concentrating to expend its forces about the summits of Nanda Devi, twelve miles away, whence for some time there came the waves of distant reverberations, repeated many times by the echoes from the glaciers and rocks, showing that up there a very pretty racket was still going on; till, like all things else, it came to an end, with sullen and fitful rumblings. By the time the thar kidneys and brains were cooked and the tea made, the cloud cleared away and revealed a white, cold scene most beautiful, and strangely contrasting with the warm and summery conditions of the morning. The natives regaled themselves with slices of thar's meat roasted on sticks, and the meal was partaken of with the best sauce. Punoo dished up his best shikar stories while we smoked our post-prandial weed, and he improvised a pipe out of a rhubarb leaf rolled up and held in the hand. Punoo described how he had stalked a huge buck thar, and got so close to him that he could almost touch the beast where he slept with the muzzle of his long matchlock, but when he pulled the trigger the match went down true on to the touch-hole and the powder fizzed (all which he described in pantomime), and the old banduk went off with a bang which knocked him on to his back. But the thar, which was the biggest he had ever seen, went away unhurt, for he had forgotten to place an offering on the shrine of the devta who had charge of the mountain, and he of course had tampered with the gun and withdrawn the golis, or bullets, consisting of six bits of old iron and some hard pebbles on top of a handful of 
good gunpowder which the 'Dipty' sahib had given him. The gun, too, had received such injuries that it could not be used at present, and, in short, he wanted a new gun, or a rifle, which he hoped the sahib, who was a bara achcha sahib and a good shot, would kindly give him, not forgetting a tin of powder and some properly fitting real leaden bullets. He would take the sahib to a jungle where were hundreds of big fat thar, all old bucks with very fine horns.

The night was now fine, and the air clear and cold. The view from the edge of the precipice was immensely grand. It extended across the deep valley, dark with pine forest and crag, at the head of which rose great tiers of snow-fields and glaciers. The summits shone out clear and white, lighted by a crescent moon against a luminous dark blue sky in which the stars sparkled with the intense brilliancy only seen at high altitudes. The air was still, and not a sound was heard save the faint murmur of the rivers which flowed far below. The precipice went sheer down from the edge of the rock, a fearful chasm. Occasional rumblings and crashings came with ominous reports on the ear from the glacier movements, but nothing like so frequently as in the day-time, when the ice would be melting under the sun's rays. All was now bound in frost, which was felt at the altitude of our cave. But a good warm at the fire which the natives kept up at the cave's mouth, with pine branches and the roots which dead fallen trees afforded, made the place look cheerful, and 'tired nature's sweet restorer, balmy sleep,' soon wrapped us in oblivion. Dreams of gigantic thar stalked successfully but never bagged, because the rifle would not go off though the trigger was frantically pulled, were the last sensations. Sleeping on juniper boughs with a good blanket wrapped round one is not so uncomfortable, but an odd point of 
stone or rock would occasionally make its presence felt and a new position advisable. Still, the night passed with apparent swiftness, and Punoo, watchful for the morning star, put on the kettle in good time for an early cup 'that cheers' and warms.

A start was made just before daybreak, so as to get on the grassy slopes at the back of the ridge when the old thar are out grazing. Clambering up over rocks and freshly fallen snow, we found ourselves on the highest point of the ridge just as the day began to break. Now was the time to scan carefully with binoculars the comparatively level slopes of grass-covered alp which stretched to the north. The view at sunrise, when the golden rays of the dawn tinged the tops of a whole circle of snow giants, was superbly beautiful. The slight sprinkling of snow from the previous evening's storm was rapidly disappearing from the ground. Following the ridge eastward, Punoo led the way from mound to mound with hollows between, carefully creeping to each point of vantage, so as not to show suddenly before every slope was examined. The tracks of thar were numerous and fresh, and the big foot-marks in the soft soil showed that it was the right place for old males to cross from the south side among the juniper and dwarf pines to the grassy side of the ridge for their early browse. Having proceeded some way up the ridge to higher ground, we at last got sight of a flock of thar grazing quietly in the hollow towards the top of the ridge where we were placed. The wind was right, blowing up from them to us. We lay flat on our faces behind the ridge. Having put fresh caps on the rifle, and slowly peeped over a rock, sure enough they were in sight not 200 yards below, eight or nine fine black-looking shaggy bucks with their heads down grazing, coming straight on towards the 
summit, where they must pass to cross the ridge. Presently they disappeared behind some intervening rocks. It was an exciting moment, but there was plenty of time to lay the barrels of the trusty Westley-Richards on the rock, comfortably pointed on the spot where they were likely to come into view. It seemed an age, but at last one head appeared, then another, about 70 yards away, grazing still quietly without suspicion. A careful adjustment of the silver bead against the dark hide, low behind the shoulder, and a steady, not jerking, pressure on the light trigger, followed by the crack of the rifle and the thud into the side (which crack not coming in the dream stalk accounted for the dream failure). Then the same with number two, which stood for a portion of a second in doubt which way to run. The rest of the flock came on for the pass with a wild rush, and bounded frantically over the top, leaving their two leaders dead on the field. Those two heads now adorn my walls-a very pretty right and left and a very lucky stalk. Punoo was delighted, and performed the usual ceremony of cutting the throats and gralloching, with many pujas to the devta or deity of the hill. The skins were also removed whole; the provision kilta supplied breakfast, and some kidneys were cooked.

What is it constitutes the pleasure derived from shooting? Is it the number of head killed without misses, or the conceived prowess of being a better shot than others, or what?

I conceive it to be derived from the successful issue of plans laid with much forethought and preparation, long dwelt on in anticipation, often thwarted after much labour by unforeseen difficulties and failures. This is certainly applicable to big game shooting: the intense excitement felt during the stalk, and the remembrance of 
agony experienced when bad shooting or other blunders have caused failure, give a most exquisite satisfaction when a fine trophy rewards the hunter's skill. The excitement of these moments leaves an agreeable impression on the memory, while the agony of the misses made lasts for life. These sensations differ from the pleasure derived from covert shooting with its hundreds of similar shots per hour, very few of which can be recollected next day. The sensation of knocking over pheasant after pheasant by a crack shot at the covert side, whose extra skill has been acquired by constant practice, must resemble more that of the man who, with a long knife, stabs pigs in the neck as they are swung past his stand by the heels in an American bacon factory at the rate of 500 in an hour; and yet men will pay hundreds of pounds for a few days' such pleasure.

There were some villagers belonging to Lata herding cattle on the grass slopes, who agreed to carry the heads and skins and some meat into camp by the gradual descent to that village, where camp was to meet me, and gladly accepted the remainder. They had huts not far off, and lived a life similar to the senners in Switzerland. They said there were many bears up higher on the hill, and white leopards, and that most of the thar were also higher up. The dense forest below was also full of game, and a tiger had killed some of their cattle. It was a clear bright morning, and favourable for ascending higher so as to explore the spurs of Nanda Devi and take sights for the survey. The ground was easy walking, very different from the previous day's climb. Following the ridge upwards, the hills became barer and more wild. Patches of snow lay in the hollows, and higher up there were fields of snow. The highest point attained was a rocky peak seemingly close up under the great snow 
masses, whence angles could be taken from all sides and the forests plotted into the map. About 4 p.m. a fire was lighted, and tea partaken of and the thermometer boiled. The elevation given was I5,000 feet approximately, the water coming to a boil at the temperature of $182^{\circ}$ instead of $212^{\circ}$ Fahr. Five hundred feet to the degree gives a fairly accurate estimate, agreeing nearly with the reading of the aneroid, which is more bulky to carry and liable to injury.

During this day we did not pass over much snow in ascending, but came down on a snow slope pretty rapidly. We saw two black bears but could not get near them. Before entering the forest we came on musk deer grazing ; and the monal pheasants were feeding under the pinetrees, but were too wary to be shot at. Punoo guided us to some deserted huts, where shelter was afforded for the night, and next day was spent exploring the magnificent forest which clothed the whole slope of the range, before returning to camp by the gradual descent to the valley of the Dhauli. These tremendous descents of 8,000 or 9,000 feet are the worst part of the business, as one always feels what a waste of labour it is to descend so low to have to come up again; besides, the heat is always increasing, and one longs to stay up in the clear cool atmosphere above. Valleys, where the main roads are, have however to be followed, and there is no help for it. Attacks of fever are often the result. Still, the work was getting accomplished. 


\section{CHAPTER VII}

DOWN IN THE DEEP VALLEYS BY THE STREAMS

THE necessity of leaving the high elevations and following the course of deep valleys for several marches, in order to get from one point to another, frequently brings the Himalayan traveller to the haunts of the best of all Indian fish for sport, the mahseer. To answer the question, What is he like ? one must have seen him in the big and rapid rivers which flow for great distances through the lower hills before debouching into the plains. The larger the river the finer the fish. In the upper reaches of these rivers, provided there is no snow-water coming down to chill the water and render it turbid, there is no finer fish to give good sport to the angler. He is like a salmon in shape, but somewhat deeper and thicker, though I have seen well-fed salmon quite as thickly and powerfully made as the mahseer. He runs from five pounds weight up to a hundred pounds, or, indeed, almost any weight, and when taken out of the water after a long and fierce fight for his life in the rapid rushing torrents he frequents, there is no more beautiful, clean, brightlooking fish than a thirty-pound hill mahseer. He shines like steel and gold. His back is dark blue or gray, changing on the belly to white and deep yellow. He will rise at certain seasons, if the water is clear and rapid, to a fly like a huge salmon-fly, but is oftener taken with a chilwa. 
This is a white kind of minnow, which is very plentiful in all rivers, and must be captured with a throw-net, or a small trout-fly on a Io-foot rod. The natives are very good at using the circular throw-net, which is whirled in the air when cast, and covers then a circle of three or four yards. It is weighted with lead all round, and sinks rapidly to the bottom. When drawn in, the fish are found taken in the side pockets, which enfold them as the net closes up. This net cannot be conveniently used by people who wear clothes.

An ordinary salmon-rod is no use for big mahseer-at least, not in my experience. There were some excellent fishermen at Naini Tal, who used to fish all the best rivers very successfully, and spend much of their leave marching along the valleys of the Ram Ganga, Kosila, and Dhauli, and other rivers. These men always used a hill bamboo or ringal, 30 feet long, which springs from the handle like a Castle Connell rod. A strong grooved butt is lashed to the lower end, and a reel attached, 6 inches across, carrying 200 yards of strongest silk line. Fixed rings are bound on the rod, through which the line will run freely. Where there is plenty of room you can cast the spinning bait, like a fly, right across the rapid without danger of injuring it, the bamboo being so limber. You drop it gently in the back eddy and spin it across the stream. If there is a mahseer lying in the still water, and you have skill enough to play the chilwa naturally, he will follow it across the current and take it with a rush. The larger the minnow the better chance of a big fish going for it. When you feel him, just look out and keep your finger clear of the line. Away he darts down the stream, and out flies 200 yards of line before you can stop him. Often you must run along the bank over rocks and shingle, giving him the butt all the time, and 
hoping he will stop before the bamboo is bent double or something breaks. If your cast is the best treble salmongut with two strong swivels, and the line be sound and the hooks extra strong, you may at last get a pull on him in the next deep pool, where he will go to the bottom and try and rub himself clear against the rocks. If he fails he will sulk for some time, and you can wind up for a second rush. You shout for a companion or a native assistant with a gaff, but it is long enough before the gaff is wanted. If you fail to bring him to the surface you must throw stones in to rouse him, and then away he shoots again for the rapids, springing clean out in the air like a dolphin, his golden sides glistening in the sun. Then slack the line a little as he falls with a splash into the clear green water, and keep it taut again till you bring him into a shallower place where he cannot sulk. You have to tire him out, and by bringing his nose to the surface you can exhaust him at last, the slender long top of the bamboo always springing as he flounders and plunges with fresh efforts to renew the fight and run for the deep pools below. If he ever gets a straight haul on the line he will smash it with one stroke of his strong tail, but he cannot do so if the point of the rod be kept steadily up. At last-after these performances have been repeated perhaps many times-you can haul him up into the shoal-water, where is a nice flat sandy beach, and then the gaff may be tried. Be sure it is held in skilful hands, or all your long struggle will be in vain. When you see him out safe on dry land, then, and not before, you may say you have fought a good fight and won a noble prize.

Our camp was pitched on a shingly flat close to the $d a k$ bungalow of Bagesar, where the clear bright stream of the Sarju river flowed close by, winding through a beautiful valley of rather wider character than is usual 
in the Himalayas. Consequently the waters were not so much hemmed in, and ran placidly, with occasional deep wide pools alternating with sharps and shallows where the stream could be crossed by wading. The river was spanned opposite the bungalow by a primitive bridge of native pattern, built out of the materials on the spot -straight pine-trees and round stones. The original plan of bridge-building in all mountainous countries seems to be identical. It is an outcome of the desire of two parties of men to meet across the river. Each builds a bracket-like structure with beams weighted under piles of stones, and with other tiers of lighter beams on top stretching further out over the water till they meet in the middle. Such was the old native sangha bridge at Bagesar, similar to many in Switzerland, and glorified in the eighth wonder of the world, the great cantilever bridge of Forth. Fishing for mahseer, which abound in the river, was carried on with varying success, two of the party going up stream each day and two down. The weather was delightful and not too hot, this being the cold season; the water rather on the clear side, but neither turbid from melting snow nor too scanty or transparent, as fishermen seem often fated to find it. The early meal being partaken of at tent doors, and rods and tackle overhauled, a start was made in the gray morning, when the air felt bright and crisp. The sun's rays were still slanting across the valley, and the river sparkling in the morning light or, in some reaches, still in deep shadow, where the air was cool, the downvalley night-breeze not having yet changed for the upward air current, which invariably springs up and increases with the sun.

To procure fresh chilwas a native is following the shallows with his throw-net on his arm, his dark naked figure 
outlined against the sparkle of a broad pool. He steals forward, and, suddenly swinging the net round his head, shoots it out with a whirling motion which spreads its folds to their full extent, and it drops on the water, enclosing a whole shoal of little fishes. To choose a goodsized chilwa, 6 inches long with silvery shiny sides, and attach it to the flight of three double hooks, is the work of a few moments, when the angler, full of eager anticipation, is ready to seize the moment of early day when the fish may be feeding. He cannot get his line out quickly enough, his excitement is so great; but at last it swings clear across the swirling water at the head of a deep and dark green pool. The shining boulders, which appear with great backs, and create a rapid eddy round their polished sides, must surely be the lurking-places of huge mahseer. The bait spins nicely, just like a fish which has met with an accident and struggles over, showing its white, glistening belly. The hand on the rod trembles with anxiety to strike at the right moment when the fish makes his rush, pursuing the bait across the current and taking it well down at the last spin. Alas! the programme does not come off. The line is pulled back through the large fixed rings and again swung out with a longer slack right across the stream, and drawn up cunningly with jerking motion to resemble the natural play of a hunted chilwa, never resting long enough for the fish to see the transparent gut or the swivels on it, but not hauled frantically through the limpid flood. Surely a big fish stirred that time, and came a good way after the bait, as a curl on the surface caused by a great tail, like the 6-inch blade of an oar, testifies. He had a good look at it, but didn't quite like it; he will not come again. Steadily casting and playing the chilwa over every portion of the pool, now balancing one's self on a convenient 
boulder, and stooping low so as not to scare the watchful fish, now wading out into the gravelly shallows half-way across the stream so as to reach the rushing current over there under the high bank-all expedients are tried, but no fish will bite.

The sun gets higher and the day advances. Yet the game goes on without result. After the hurry and excitement, things seem to fall rather flat. One's arms get a bit tired wielding a 30 -foot rod, light though it be, and something seems wrong with the reel. The chilwa, alas! becomes draggled and will not spin, and a new one has to be adjusted and a fresh pool sought. Here, however, great oak trees hang over the very place where one is certain a big mahseer is lying ready to be caught. The pangs of hunger are beginning to be felt, and the angler's temper gets short. If he doesn't get a fish in the next three throws he will go to breakfast. He takes four throws, and a fifth, and not a fish will stir. He sulkily retraces his steps in a very hot sun back to camp.

The pool below Bagesar is wide and deep, and a temple stands by the river, and there is a ghat like those at Benares, where the bodies of dead Hindus are burnt, and the remains thrown into the sacred waters. The souls of the faithful must thus attain future happiness, whose bodies are returned to the all-embracing bosom of holy Ganga. The drop returns to the ocean, so the soul to its Creator. Simple faith of Hindu and Buddhist alike. The realistic features of this beautiful religion, however, are not so beautiful in actual experience. No bait or fly, no matter how alluring, would ever stir a fish in this likelylooking pool.

Whether the mahseer migrates and goes down to the plains, where the water becomes warm and clear, is a question which observation alone can solve. It is certain 
that in the lower reaches of the great rivers, where the white mud gets deposited, and the water flows out into the plains and ceases to tumble over rocks like a roaring torrent, that at certain seasons excellent fishing is obtained, and the fish run very big-seventy pounds or a hundred pounds is not uncommon. Here it is best to fish from an elephant, as the rivers are far too big to fish from the bank, and wading is not very safe. Alligators of immense size, which abound in the plains, can come up almost into the lower hills, and naturally interfere with mahseer fishing.

Of course, in the rains, when these rivers rise into immense cataracts, fishing ceases. It is therefore a critical thing to hit off the right moment and the right place to go to enjoy the pleasures of mahseer fishing to perfection, and the movements of the fish require, as in the case of salmon, more study. I have seen great shoals of big mahseer following one another in strings, all going up stream in the clear waters of the Kosila. This was in the month of May. I have fished successfully for mahseer from August to November, and in lower streams all through the cold weather, and have had both bad and good times; but the good times made up for the bad, and it is a noble sport. The pleasures of fishing are enhanced by the beautiful scenery and wildness of the numerous rivers which cut through the Himalayas; also there is always a likelihood of getting a shot at game, big and little, in the neighbourhood of the rivers, and a gun should be carried by a chaprasi accompanying the fisherman. A good gun-bearer, who will be always close by at the proper moment, and will hand the second gun to the shooter and not run away, is a valuable man, and one not to be ill-used or scolded, much less beaten. Rather should he be treated as a friend and a gentleman, 
which in feeling and manner he very often is. Some people think that the 'nigger,' as they call him-though he is no more a negro than a red native of Canada is an Indian-cannot be managed except by thrashing, and that the only language he understands is gross abuse of himself and his maternal relations. I have in many years never but twice had occasion to strike a native, and have found both hill-men and plains-men, paharis and daissis, Mussulmans and Hindus, high caste and low, as a rule most faithful and sincerely attached to the sahib whose service they have undertaken and whose salt they have eaten; and in many cases I have met with men whose courage, high principle, and honourable feeling would do honour to the most educated Christian gentleman. 


\section{CHAPTER VIII}

\section{FORESTS AND RANGES OF THE MIDDLE ZONE}

ON the vast ridges of elevated mountain masses which constitute the Himalayas are found different regions of distinct character. The loftiest peaks of the snowy range abutting on the great plateaux of Central Asia and Tibet run like a great belt across the globe, falling towards the south-west to the plains of India. Between the summit and the plains, a distance of fifty to seventy miles, there are higher, middle, and lower ranges, so cut up by deep and winding valleys and river-courses that no labyrinth could be found more confusing or difficult to unravel. There is nowhere any tableland, as at the Cape or in Colorado, with horizontal strata of rock cut down by water into valleys or cañons. The strata seem, on the contrary, to have been shoved up and crumpled in all directions by some powerful shrinkage of the earth's crust, due perhaps to cooling; and the result is such a jumble of contorted rock masses, that it looks as if some great castle had been blown up by dynamite and its walls hurled in all directions. The great central masses, however, consist generally of crystalline granite, gneiss, and quartz rock, protruding from the bowels of the earth and shoving up the stratified envelope of rocks nearly six miles above sea level. Six miles is not a very great rugosity on a globe of the size of the world, but it amounts 
to a good deal of climbing and many changes of climate when you attempt to surmount it. The higher you get up, and the further from the foot hills, the rougher and more difficult becomes the climbing; the valleys are deeper and more cut into ravines, the rocks more fantastically and rudely torn asunder, and the very vitals of the earth exposed; while the heights above tower to the skies. The torrents rushing from under the glaciers which flow from the snow-clad summits, roar and foam, eating their way ever deeper into the misty gorges. The vegetation becomes more and more of a European character and reminds one more of Switzerland, without the cockney element which destroys the charm of the Alps; and the natives become more hardy, self-reliant, and interesting.

I will now describe a trip to the higher valleys and across the snowy range. It was in June, I864. The party consisted of four, the Hon. Robert Drummond, B.C.S., brother of the then Lieutenant-Governor North-West Provinces, Henry Hodgson (on a visit to the writer), Lieutenant-Colonel Smyth, Inspector of Schools, North-West Provinces, and myself, on leave. Stores were laid in at Almora to last three months, consisting of tinned soups and meats for emergencies, ammunition, oatmeal, groceries in bags, and green goggles to protect the eyes when crossing snow. Warm woollen clothing was taken, and tents and camp equipage of the lightest, divided into loads of thirty sers, or sixty pounds each. Flour and rice, milk and ghee, could be bought at most places.

Ponies were taken to overtake the baggage and servants gone ahead to Pithoragarh, four or five marches east of Almora. The lower hills looked very much scorched up by a blazing sun, and the air was thick with the dust rising from the sweltering plains to southward, and smoke from 
numerous jungle fires. The road, cut out just wide enough for horses and foot passengers to wind a zigzag along the ridges, or dip into lesser valleys, only to climb again to the tops of similar ridges, was anything but a straight one : but was fairly good and monotonously picturesque. Occasional villages nestled in hollows, or on slopes with terraced fields, and streams ran in water-courses for irrigation, or trickled down their rocky channels, or turned primitive corn-mills. The houses of the Kumaon peasants are of stone, roofed with shingles or flags, with small balconies and verandahs not unlike those of many parts of Switzerland; and the people looked fairly well-to-do, cleanly clad in white cotton garments, the women working hard in the fields while the men smoked their hookahs and nursed the babies. Their lithe figures are well proportioned, and their carriage erect, from carrying loads on their heads.

At Gangoli Hat we put up at a $d a k$ bungalow, where is a magnificent sacred grove of deodar trees. Coming out of the glaring sun, you find yourself suddenly almost in darkness, under the shade of a dense canopy of almost black foliage, the great stems of the oldest trees standing close together, surrounding an ancient shrine. The younger trees cluster on all sides like the children of the old patriarchs, which look as if they might be 3,00o years old, so massive are their giant boles.

The bark of the older trees is black, lined out with silvery cords, and the stems give the idea of great strength from their perfect proportions and great spreading roots, while the younger trees, with glistening feathery tops, make an agreeable contrast. It is like entering a great cathedral, cool and restful, most impressive : there is no sound but the musical murmur of the light air in the branches high overhead, and even the flies do not bustle 
and disturb you here. Next day we walked down into the deep and hot valley of the Ram Ganga, a branch of the Sarda river which joins the Kali at Rameswar. This river comes down through a deep gorge from the slopes of Nanda Kot, but does not issue from any glacier; so its waters are clear and not too cold for mahseer. We fished with salmon flies, bathed in its cool waters, and enjoyed our tiffin by the river, which looks, as it swirls over great smooth boulders, like any Scotch salmon river, while above on the grassy slopes are great pines like Scotch firs. The walking on these slopes is terribly slippery, from the carpet of long spines of the chir-trees, and big nails in one's boots are much needed. A good iron suspension bridge crosses the stream, and leads to Pithoragarh, where the officers of a detachment of Gurkhas entertained us next day, and reported having taken some beautiful thirty-pound mahseer.

Pithoragarh is on an open plateau, with villages and much cultivation, and there are a few bungalows. The descent to Askot, and thence down to the valley of the Gori Ganga, is hot and steamy. This is indeed a hot and deep gorge, with splendid forests of very tall chir pines clinging to the sides of the towering hills, which spring straight up from the river banks. Palm-trees also mingle with the pines, and vie with them in the graceful curves of their black stems and feathery heads. Daylight scarcely reaches here, the sky-line being some thousand feet above the river and almost overhead among the distant tree-tops; and the icy water, white with quartz mud from the Milam and other glaciers, sweeps by in a vast volume of water 70 yards wide. Here there are leeches on every stone, which fasten on your legs and suck your blood with great avidity if you do not use precautions in the shape of thick puttees for protection. 
One of us, wearing only stockings, had thirty bites and lost half a pint, and from tearing off the venomous brutes suffered a good deal of irritation. There are hundreds of little flies also, called moras, which buzz round in an innocent sort of way and light on the under-sides of your hands and exposed places; most noxious pests, for if they succeed in getting half a minute unobserved they will insert a poison under the skin, which makes a round red blister. Very hungry mosquitoes also abounded in this valley, but they are gentlemen beside moras. There were big yellow gadflies also, which stuck swords in through one's clothing; and even the house flies, which swarmed in myriads, had nasty stings. Camping here was not all joy, and with six different kinds of poisonous wounds in one's body it was not easy to come up smiling. Our carriers were seized with a holy horror also of the evil spirits which abound in this mysterious region. They stated that the jungles were also haunted by jungle men, who had no houses and wore no clothes and lived on carrion. If we went up the Gori river,* where no path existed, we should certainly never return alive. However, as the valley was left blank in the maps, and the forests under Chipula Hill were magnificent and very extensive, I was the more anxious to explore the haunted jungle.

Sending our heavy camp with Mr. Drummond by the road which follows the Kali river, Hodgson and I started with light equipage and two servants up the Gori. Leaving the road, we wound our way through dense jungle up the left bank of the river, and stumbling among great rocks, we found a path through dense forest and masses of creepers. We came at last out on the heights above, where the caves of the wild men were said to be. It was

* The branch of the Kali coming from Milam. 
certainly a weird and uncanny sort of jungle. There were troops of great black-faced monkeys, langurs - the biggest and most human-like with snow-white beards and hair-which swung from branch to branch by their long prehensile tails, and grinned and scoffed at us with hollowsounding roars. We did not see the wild men's homes, but one very poor-looking, black, lean man came and pointed us out the best track. He certainly had not much in the way of clothing, and carried a diminutive kulhari, or axe, with which he was ingeniously scooping out a piece of hard timber into something resembling a bowl. He said it was to boil water in. He certainly looked the nearest thing to what Darwin would collect as a specimen of a link in the chain of ape-begotten humanity. He talked, however, Hindustani, or what passed for that language ; and being asked if he had ever seen a monkey light a fire and cook his food he replied, with quite an intelligent smile, as if he was not going to be humbugged, that only man could cook food.

At last, towards nightfall, we came to camp in a charming grassy dell, where a clear stream ran swiftly among beds of lovely flowers, and then tumbled into space over a flat ledge of rock into the valley below. Opposite, at the head of a great amphitheatre of precipices, ${ }^{*}$ the fine snowpeak of Chipula towered above our heads. It was a lovely evening and a beautiful spot. There was a waterfall shooting down opposite off a similar ledge of rock: by counting the seconds and watching a particular spot in the white water descend to the bottom, I made the height I,90o feet. The strata happened here to be lying nearly horizontally, with bands of harder rock which was hollowed underneath and protruded all round the circus like a cornice. We pitched our small tent here and * Like the Cirque de Gavarnie, but in capital letters. 
bathed in the stream, but the moras and mosquitoes took most unfair advantage while we dried and dressed ourselves. There were tracks of bears; and gooral, or Himalayan chamois, were seen on the precipices, but out of range. Here inhabit the chir pheasant, the koklas, and the Argus with his scarlet eyes and blue horns and wattles, and the monal is found further up. These jungles are full of beautiful shiny-leaved evergreen trees; and shrubs of many uncommon kinds and orchids abound, clinging to the stems of the oaks. There are several kinds of feathery-leaved acacias, and many kinds of flowering creepers, which hang from branch to branch. Box-trees are occasionally met with higher up, and rhododendrons and magnolias of several kinds abound, and as to ferns, the profusion of varieties is incredible.

Next day we moved our camp to a place called Kunaar, where there were no villages or inhabitants, right under the peak of Chipula, which is 13,000 feet in elevation and has a considerable cap of snow. The hot weather was melting it rapidly, and in the silent night the thunder of repeated avalanches woke us, as if just above our tent. We camped on a nice grassy slope with a pond of water, and when the bheesty went to fill his masak, he was confronted by a herd of thar, which were coming to drink. He ran to the tent in a great hurry, but on discovering our camp the thar had made tracks into thick jungle. There were signs of every kind of game and wild beasts, and we determined to be upon the grassy slopes at very early dawn. There were some very jagged-looking rocky precipices, which the thar frequented.

Next morning we were out when the morning star, Mercury, just twinkled above the horizon. No streak of daylight had yet appeared, but there was the cold feeling in the air which precedes the dawn. Climbing steadily 
up the slopes, we separated to take different beats, Hodgson below and I above the rocks. He was more fortunate, and shot two thar; while I only got one long shot, and missed from blundering incautiously over the tops of one of the many ridges with ravines between. There were two fine old bucks grazing, which, from the similarity of their colour to the dark rocks, we did not notice till they saw us and bolted over the next ridge. Peeping carefully over the next, my shikari quickly put down his head and beckoned to me. It was my good fortune to see two musk deer grazing quietly not roo yards off. They are really pretty little deer, most graceful, with dark brown, red, and gray coats of a wiry sort of hair like porcupine quills. Their little pointed horns and great black eyes and noses are striking, and their little feet with four spreading toes are useful for passing over soft snow. Their gambols on the very edge of a frightful precipice were watched for some time, till the buck seemed alarmed at something, perhaps a snow leopard. Creeping behind the rocks above, he stood for a moment on the point of a rock, scenting danger somewhere, and I was lucky enough to drop him with a bullet behind the shoulder. The other made tracks, and the snow leopard put in a sudden appearance, but then vanished before he could be covered with the second barrel. The snow leopard* I came across several times in the highest ranges. $\mathrm{He}$ is white with brownish spots, and not so big as a common leopard; a beautiful animal with a soft and pretty skin. They are not uncommon, and do much damage among the sheep and goats of the Bhotias, who keep big dogs to protect their flocks.

The musk deer (Moschus moschiferus) is found above

* Felis uncia. The ounce, described by Jerdon as found at 9,000 to 18,000 feet elevation. 
8,000 feet, and very high up near the snow, in birch and other forests. It is a slender, graceful little animal, smaller than a roe deer, and has the upper canine teeth very much lengthened, like the tusks of a walrus. They are quite 3 inches long, and stick out below the animal's chin. It is not quite clear for what purpose these tusks are intended. They would, however, inflict a severe wound if the animal struck down with them. The male has a curious bag or pod under his body, which contains quite a quantity of stuff like brown seeds. The musk pods are worth their weight in silver, and are an article of commerce among the hill-men, who hunt them steadily, so that the animal is getting very scarce. The smell from a fresh musk pod is nearly as strong as a skunk, but not quite so noxious. The monal pheasants were plentiful on Chipula Hill, and we took our shot-guns in the afternoon to secure some specimens. They take a lot of big shot to knock them over, and are very hard to get near. In the daytime they haunt the ledges of rocky precipices, and when disturbed shoot off and down into the valley below like a flash of blue lightning, the brilliant peacocklike neck, which contrasts with the rufous breast and the white patch on the back, catching the eye. Their plaintive shrill cry, between a whistle and a screech, gives warning to others of danger near; and if by chance you drop one with a rapid shot, his heavy, plump body, nearly as big as that of a goose, generally falls half a mile away down in the dense jungle below the khud. In the evenings and mornings you can stalk him as he feeds under the great pine-trees, rooting for seeds and insects in the flower-spangled grass. He will, however, seldom let you get within shot, and runs a long way before taking flight; but he can fly very rapidly, with strong strokes of his short wings, fanning out his broad tail like a capercailzie as 
he shoots away. His skin having become an article of commerce for ladies' hats, he will doubtless disappear from his native hills.

The next march was a trying one, for, having got up at 4 a.m. to have a final hunt for thar in the precipices, which produced nothing but one gooral, we struck camp after a hurried breakfast and started downhill, intending to cross the valley and then encamp at the foot of a high pass which leads to the valley of the Kali river, where Mr. Drummond waited for us. The descent was hot, down a roughish khud into the bed of the stream, which was nearly dry and all rough shingle, 5,00o feet in three hours. Then began the ascent up the dry bed of another stream (the Taijam Gar), and following that for three hours we kept steadily on, expecting to find water and camp for the night. Alas! there was no water, and not even any snow to melt; so we clambered on and on, always over rocks, under the shade of enormous sycamores and horse-chestnut trees, a perfectly primeval forest. There was no path but the shingly stream-bed; and if we tried to force our way through the jungle, it was a hopeless tangle. The coolies, with baggage and tent, though excellent carriers, were left far behind. Still we climbed upwards, hoping to reach the summit of the pass (called the Nari Danda) before nightfall. Tramping since 4 a.m. was not a good preparation for this climb; knees and shins began to feel a strange stiffness as if the joint-oil was exhausted; sitting down was fatal, as the knees seemed to stiffen up at once. The rays of the setting sun were on our backs all the afternoon, for we were going eastward, and a June sun is not kind. Water there was none, not even a trickle from a friendly rock. The top of the pass surely must soon be reached, the steepness increasing; at last it seemed to come into 
view against the sky; but on reaching it there was another height above it, and then another, and so on for five or six times.

Suddenly there was a revelation. There stood over the stream-bed on a grassy slope a pine-tree, the like of which I had never before seen. Every pine and fir in the hills I was absolutely familiar with, but here was a strange and new and beautiful pine-tree like the old familiar Scotch fir, but black in the stem and with much shorter spines, and with cones much smaller even than the Scotch fir and oval in shape. Was this a new discovery in forestology? The thought was too exciting, and forgetting the weariness of the tired limbs, I proceeded to climb up and get specimens of leaves and cones, and to make notes of the new discovery. Hurrah! Here was a grand reward for a hard day's work : before us there stood an entire forest of the new pine-tree, and at last the real summit of the pass. We sat down to rest and watch the last rays of the setting sun shining on the Nari Danda and the stems of these new wonders. I had already decided to christen them and make a name among botanists, but, alas for the vanity of human ambitions! the trees turned out to be the Pinus Brunoniana, inhabiting Nepal, of which this was the western limit. But the finding of it on Chipula Hill did freshen up my weary limbs and make me feel quite rested. In a short time our shikaris came up, who were as anxious as we were to reach the next village and get food and water.

Luckily, there was a good path leading down the pass to the village of Guladi, where we expected to find our servants and camp pitched, and we started again wearily on the downward tramp. The height of the pass was fully 4,00o feet above the village, and we could see lights below us some four or five miles off. Strange to say, on

$$
6-2
$$


this range, the Nari Danda,* there was no water anywhere, and we suffered from extreme thirst. The natives, however, found some rope-like creepers hanging from the branches of the trees, which they cut across with their axes. We held our leather drinking cups under the fresh-cut creeper till a good supply of clear water flowed into the cups, and we quenched our thirst delightfully in the native fashion. Taiz Singh, my faithful jamadar, who had been sent on to Guladi village by the Kali river in charge of the heavy baggage and tents, luckily had a head on his shoulders, and getting anxious about our nonarrival, had sent a chaprasi with torches ready up to some shepherds' huts, to await our coming and signal by torch when we got over the pass. We met the chaprasi, who was looking out for us; and when we appeared his joy was great, as they had almost given us up and imagined that something had befallen us from the evil spirits of this deserted jungle. Our signals were answered from below by waving lights, and we presently met several kind men from the village who had come up to guide us to our camp. The sound of rushing waters met our ears, and we ran to the banks of a rapid stream. Hodgson could not resist a plunge bodily into the stream, and did not suffer, though the temperature was about freezing, the water coming from the melted glacier. When we did get safely to the village we were escorted by quite a procession of torch-bearers, and arrived about midnight to find an excellent dinner with hotch-potch soup and fowl ready, and Sirdar Khan Khansamah in spotless clothing standing ready to wait on us. The hot tea with excellent milk was what we did best justice to, and we turned into comfortable beds to sleep, such sleep as the tired only know. Next day was Sunday, and we slept

\footnotetext{
* Danda means a path or ridge.
} 
FORESTS ANI RANGES OF THE MIDDLE ZONE 85 till noon. On waking and attempting to stand up, I found my knees almost locked and unbendable. Taiz Singh, who understood the art of shampooing thoroughly, soon restored the action of the joints, rubbing in plenty of salad oil ; and the day of rest was thoroughly appreciated. We had done three long marches and close on I4,00o feet up or down, and been on our legs twenty hours almost on end. 


\section{CHAPTER IX}

THE UPPER VALLEYS AND COUNTRY OF THE BHOTIAS

WE were now about to enter the upper valleys of the great Himalayan range. The province of Kumaon, under British rule, includes the country of the Bhotias up to the confines of Tibet. The name Bhotia applies to the upper hill tribes, which are not Hindustani and not Hunia, but an intervening race speaking both languages generally, their own being of an intermediate type. In the Kumaon province there are the districts of Bians, Dharma, Chaudans; also Juhar and the Milam and Niti valleys.

The most difficult portion of the journey to the summit of the range lies where the traveller emerges from the deep valleys of the lower hills through the most precipitous defiles to the upper Himalayas, where the valleys are broader and more open, the climate much cooler, and instead of dense jungle there are grassy slopes and tall pine forests.

The route lay along the course of the Kali river, which, rising under the cluster of snow-clad peaks which form the main divide between British territory and Tibet, descends through the Bians valley, and forms the boundary between Kumaon and Nepal. It is joined at Titlakot by the Dhauli, which comes down from the Dharma valley. Between the two lies the district of Chaudans, which culminates in the snowy peak of Irvajung, 21,500 
feet. On the Nepal side stand Namjung, r8,470, and the very conspicuous peak of Api, 20,00o; mountains little known to fame and never explored by white men. Above Titlakot commences the country called Bhot. The Bhotias are a fine highland race, possessing some of the Tartar character of the Tibetans. They are a most intelligent and industrious people, and live by trading; also they grow some barley and oats in their valleys, and keep sheep, goats, cattle, yaks, and numerous ponies, which they breed and graze on the grassy slopes of the upper hills. The Bhotia ponies, called gunts, are notoriously good, sturdy, sure-footed animals, twelve to thirteen hands high, and can carry any weight. They climb anywhere a man can go, and their feet are so hard that they require no shoes. The religion of the Bhotias is allied to Buddhism, but they believe largely in fairies or deities of the hills, and they are not particular about caste. They spin and weave the hair and wool into strong rough cloth-of which their coats and loose trousers are madeand blankets, which are heavy and soft to keep out the cold. They migrate south in the winter to the lower valleys, and in the summer cross into Tibet and bring down salt and borax, which they get from the Hunias, on goats' backs; and they return northward with flour and rice. Their villages are built of stone, with balconies and flat roofs of mud; and numerous poles surround the houses with white flags, which flutter in the breeze to keep off the evil spirits.

To reach this country one must pass through the defile of the Kali river, which is very deep and narrow, cut down between a whole cluster of lofty peaks, for four long marches. The river roars perpetually between precipices of rock, the height of which must be anything up to Io,ooo feet above the river, covered with dense jungle of 
spruce, silver firs, and pines of the usual sorts, besides sycamores, horse-chestnuts and oaks. Sometimes the path rises to pass the top of a precipice $r, 000$ feet above the stream, then again it descends by steps cut in the rock to the very edge of the torrent. The next outjutting crag is more difficult to negotiate, and iron pegs have been let into the face of the rock in places, to support a gangway made of poles and loose stones laid on top, overhanging the roaring waters which race and foam at its base. In one place the cliff is so hollowed out that a stone falling from this rickety gallery would drop on the Nepal side of the river.

In the rains traffic is entirely stopped, as landslips usually cut the road. Being an important trade route between Hundes and India, the Bhotias by custom supply men from every village annually to repair damage done in the monsoon, otherwise it would be quite shut up. The Indian Government, being anxious to encourage trade for the benefit of its subjects, Bhotias and Kumaonis alike, does not levy any duty on the salt brought into India by these passes. Everywhere else the salt is a dutiable product, and a source of great revenue to the Exchequer. If the import of salt on the backs of sheep and goats were stopped, then the flour, rice, sugar, and tea grown in India would cease to find a market in Tibet, and the Bhotias, who are good subjects of His Imperial Majesty, now well-to-do and driving a good business, would be starved and ruined. Having struck the Kali river at Darchula, we had to tramp steadily along the hot low valley for three marches, following this, the only, track, to overtake Mr. Drummond, who had gone on ahead. The view from some points of the road looking upwards is remarkable. The immense height of the great mountains on the Nepal side, to which there is no access or 
bridge over the river, is realized. The precipices often overhang and impede the view; at other places the hillside slopes back at an angle of 50 degrees, clothed with fine forest of pine and silver-fir trees, towering above one another to such a dizzy height that the top seems three or four miles up in the air. The trees outlined against the sky, tall groups of conifers, seem no bigger than pinpoints. Some day these forests will be explored, and yield great stores of noble straight deals; but for many years to come they will grow in peace, a truly grand stretch of primeval jungle.

We came across several Bhotia encampments and large droves of strong, big goats accompanied by their drivers. The goats were allowed to graze on the surrounding slopes, while their loads, in double bags or packs made of strong yaks' hair cloth, were piled in heaps while the men cooked their food. They chose places where there were caves and overhanging rocks to afford shelter from rain. They kept great hairy Tibet dogs, exactly like the Maremma wolf-dogs, with pointed noses and ears and bushy tails, to guard their flocks from leopards. Where the goats or sheep are grazing you always see two or three of these big fellows lying on different points of rocks as if asleep; but they are keeping a sharp look-out for their prowling enemies. At night the goats are driven into the caves, around which walls are built, and on these the faithful dogs sit watching, and giving the alarm if leopards come round. I have myself seen two of these dogs, which I purchased from the Bhotias-one yellowishwhite with long silky hair, the other black, like a big sheep-dog, but much larger and heavier-tackle a leopard which came at dusk round my camp, and succeed, after a sharp scuffle, in scaring him off, greatly to the relief of my ponies, which, tied near the tents, were trembling 
and snorting with terror. Leopards will seldom face fires, and the natives take good care to keep a spark burning and to shout when the dogs bark.

We overtook Mr. Drummond at Gula Dhura, in a beautiful camp under giant sycamores on a ledge some distance above the Kali. Here, when sitting outside our tents after dinner, enjoying the cool, still air and a scene quite beautiful, lighted by a lovely moon glinting through the dark foliage overhead, there came a troop of flying squirrels, leaping from branch to branch and tree to tree. The performance is a peculiar one. They are like very large squirrels, say 3 feet long, with wings as well as legs, and a long bushy tail. They feed on berries and acorns among the branches, and you can see them running up the stems and to the highest branches of the trees. Then they appear to spread their wings and shoot themselves into space. With a kite-like motion they cross the gap to the nearest tree, landing among its lower branches safely, and ready to climb up again and take another flight from the top branches as before. Not knowing what sort of animals these could be, we watched them for a long time with much astonishment. The enigma was, however, solved on one being shot and examined. They possess a light, thin, web-like membrane like the bat tribe, which stretches between arms and legs and tail. When flying, they simply spread out their legs and arms, and become kites, or parachutes, able to shoot distances of thirty or forty yards in a slanting direction.*

* These were probably the Pteromys magnificus, described by Jerdon as body 14 inches and tail 20 inches long, which is found in the Himalayas up to 9,000 feet elevation. But as there are eight different species of flying squirrels in India, all of similar shape and habits, it is not impossible that the species given is incorrect. The skin was certainly dark brown with rufous belly, fur very silky and beautiful. There are other kinds much lighter in colour, and even white on the belly. 
Next day was a long march to Budhi, a principal village of the Bians Bhotias. It is a long and tiring march for coolies carrying loads, especially as there is not a drop of water for fifteen or twenty miles. They call it Nirpani (no water), and there are some very ugly places, where even one false step would send the cragsman down into the depths below to be swept away in the stream, a swirling black icy cataract which shoots with hideous velocity down its rocky channel, and into which anything entering will never be seen again. No ponies can traverse this route. Ours had been sent back long ago to Naini Tal on account of this passage. We luckily came at a good season, when the repairs had been done, and took water with us and started early. The most jumpy part of the passage was where there occurred stone-falls, resembling waterfalls, which shot down from the cliffs above, sometimes gravel and sometimes boulders of considerable size. These you could see bounding a long way up, and you had to wait at a sheltered spot for a lull, and then rush across the gap and take your chance. Luckily they always kept in the same course, and the stones seldom lit exactly on the path; but you could hear them hurtling through the air like shot from a howitzer, and as they went by with a whizz you felt creepy. The natives told us that many people get killed by being hit; and they always do puja to the evil spirits of the Nirpani before venturing to traverse its dangerous ledges. We got by all safely and camped at Budhi in an open valley. We had passed between Namjung and Irvajung, I8,000 and 21,000 feet high, through a slit comparatively not much above the level of the Indian plains and excessively hot. We seemed suddenly to emerge from a hot and subterraneous funnel into a cool and open region, where the vegetation was almost Arctic. The dense forests had 
given place to almost bare hills, with birch and Pinus excelsa and juniper on the lower slopes. There were meadows, and even oats in fields, and the stream was winding over flats with gravel beds and the usual wild flowers found in Swiss valleys. The sultry heat of the previous marches gave place to cold and clear air, with the bracing feeling of northern climates, which strikes one as homelike and delightful after the plains of India.

Our tents were pitched near the village of Garbyang, the principal one in Bians, of which the pudhan, or headman, came at once with offerings of sweets and fruits to our camp. Here also we met Colonel Smyth, Inspector of Schools, who had been visiting all the village schools, and was much pleased with the proficiency of the scholars. Colonel Smyth was an experienced traveller and explorer, and had made many trips across the frontier into Tibet, and been over most of the passes, and was also a great shikari and mountain climber. He was joining our party for the purpose of getting as far into Tibet as possible at this most easterly point of the British Himalayas, which hitherto had been little explored. He had tried several times to get beyond Taklakhar, and had always been turned back, but was of opinion that so large a party as ours would find much less difficulty than a single sahib. He had fitted out an expedition to go to Lhasa, but after many delays in trying to procure passports through the Governor-General and the Ambassador to China, he had been obliged by the orders of the former to abandon the proposed journey, as the Government of India would not give it their sanction. He had selected, however, some very intelligent young men out of the Bhotia schools, who were being trained at the Roorkee engineering college under Colonel Montgomerie, chief of the Survey of India, to make surveys with the best instru- 
ments. They were to be sent in to explore this unknown country.

We found it very cold at nights here, but good fires were kept up in front of the tents, with a wall built of loose stone, Tibet fashion, all round the fire, to keep off the cold breeze. Extra clothing was also required, and blankets at night. The following morning, on waking, we heard the bleating of many sheep, and on looking out of the tent door found a long string of the quaintestlooking sheep coming down from Tibet by the Bians Pass. They had long, straight horns, straight out on each side of the head, similar exactly in shape to the horns of the Ovis Poli, only a few being curled close to the side of the head like the Ovis Ammon and Scotch horny. These sheep were very tall on the leg, as big as a Lincoln sheep, and had fairly fleecy wool. The quaintest sight, however, to our eyes, was to come. Three objects approached our tents, with little slit eyes and red cheeks and broad grins on their flat red faces-whether men or women it was not easy to tell, for they had smooth faces and their hair flattened on the temples, black greasy pig-tails coming out from under their broad Quaker-like hats. They were squat, thick figures, with a waddling gait, and wore thick woollen coats, and trousers gathered in at the ankle, and woollen boots, and round their waists dirty kamarbands, with knives and chop-stick cases stuck in them. Their coats were open in front and bulged out above the waist, as if they had crammed all loose property into the space. In fact, wooden cups for drinking tea, neatly turned from knotted horse-chestnut, which grows in Nepal, tobacco bags and others made of leather, wool for spinning, and all sorts of sundries were carried in these capacious breast-pockets. They wore Birmingham-made goggles, and carried each a green 
cotton umbrella of Gampish design, and spun woollen yarn diligently on to a large bobbin, which was kept perpetually twisting as it hung by its newly spun thread.

Coming to our tents, they put their comical faces inside to look at our tent gear, at which they laughed and jabbered a new and strange lingo, which we were told was the Hunia language-the language of the Huns, the same, perhaps, as that spoken by the Huns who conquered China and the Asiatic world 400 years B.C., and as 200,000 horsemen overran Europe to the gates of Rome in the fifth century A.D., being at last defeated at the gates of Chalons. The Hungarians claim to be descended from the Huns. Their language and features are, however, opposite as the poles to those of the Huns; and, in fact, the Huns who conquered the Goths passed on westward, and were defeated and lost among European races. The branch of the Huns which was driven south by other Tartar races, no doubt, was stopped by the Himalayas, and preferring these wilds and a nomadic life, has remained in this inhospitable country ever since. In any case, it is marked correctly in most modern atlases as Hundes-the country of the Huns-and the people are called Hunias. These men were particularly quaint and amusing; they talked a few words of Hindustani, and spent quite a time inspecting our camp and asking questions. They told us that the snow on the passes was very deep, and that no one could get across; yet apparently they had themselves got over quite safely. It was reported, no doubt, that we were intending to cross over, which, as we afterwards learnt, they were all anxious to prevent.

Having summoned the pudhan of Garbyang, Boodoo by name, a most intelligent man, and his brother Jussoo, who spoke the Hunia language well, they agreed to supply 
stores, consisting of flour, rice, and sattı (parched wheat), sufficient for a stay of one month, also to supply sixty carriers from the Bhotia villages, each man to carry food for himself for a month beside his load. They agreed to come with us and act as guides and interpreters. We also hired jhobus, or tame yaks, to carry tents and other loads, and ponies to ride. I purchased one very nice strong gray pony, and hired another for myself, a very plucky little bay. We engaged also shikaris, excellent men who were first-class mountaineers, good stalkers and trackers, and very keen to make a good bag. It was now July, and the rains were almost breaking on the lower hills and plains of India. We were anxious to get across to the other side, which has a comparatively rainless climate, as soon as possible. The pudhan informed us that he had been given notice by messengers that the sahibs were on no account to attempt to cross into Tibet, as it was contrary to the orders of the Chinese authorities. This is, however, the usual custom.

While things were getting ready we determined to have a try for burrhel, or wild sheep, in some valleys close by, in Nepal. We gave out we were going there to shoot. It was, however, our intention to cross over the Tinkar Pass in Nepal, which would get us close to Taklakhar and take the Hunias unawares.

Our light camp was pitched on sloping ground in a considerable valley in Nepal, east of the Kali, on the south bank of a rushing torrent which drained the extensive slopes of the lofty peak of Api. Above the tents was a snow slope coming down close to the camp, which was on gravel with some scant vegetation, and slanting down to the river some $5^{00}$ feet below. In places this valley was filled up level with snow, forming a convenient bridge to cross from the south to the north side, which was beauti- 
fully wooded with birch and other trees. These bridges were constantly used in marching up the valley, to cross from one side to the other. The torrent had cut a tunnel for itself, through which its black and icy waters roared in a fearful manner. The Bhotias showed great caution in crossing, and generally sent the yaks on ahead. These sagacious animals always by instinct discovered the strong places to cross, and made steps for the rest to follow. Sometimes only a very small arch of snow, a few feet wide and perhaps not six inches thick, remained unmelted, yet the whole caravan would cross in safety. The hills on the north side of the valley were covered with forest, and cut up into chasms by old landslips; above were steps and old moraine, with grassy slopes and juniper bushes and Alpine roses. At dusk we searched the hillside with binoculars, and sighted some burrhel grazing, also a big brown bear. The black bear is usually found in Kumaon, and the brown in Kashmir ; but a few of the latter exist in these valleys.

At earliest dawn some of the Bhotias were to start with their dogs and hunt the upper ranges, and drive the burrhel down to us. We left camp about 7 a.m. and crossed on snow to our places. The shikaris who managed the hank chose our positions, and we waited patiently, concealed among the juniper bushes. We could hear the hounds, which were a cross of the Tibet dog and the pariah, giving tongue above us a long way off. Presently a musk deer came cautiously slinking along, and received his quietus. A herd of burrhel ran along out of range, and turned up the hill again. They are brown like a mouflon, white on the belly, and about the size of a Leicester sheep. As usual among the sheep tribe in the wild state, the wool on the back is more like hair, or what is called 'kemp' by woolsorters in reference to Scotch or Welsh mountain sheep, 
which have still some of it, though climate and feeding have converted the hair more generally into wool.* There came along presently a great brown bear, shambling at a great pace through the juniper bushes, and looking over his shoulder in a quaint manner to where the dogs were yapping on the hill half a mile above us. He seemed to scent danger, for he changed his course and sloped off westward. We started to run to intercept him at a convenient dell which he was making for. My shikari Munnoo, an active young man, lean and hardy, led the way, carrying my second rifle. The high elevation, $\mathrm{I} 6,000$ feet, made running almost an impossibility; but we struggled on, crashing through juniper scrub, until our breathing became too laboured to go forward, and we both threw ourselves down and panted. The bear did not suffer from the rarefied air, and only afforded a long shot as he scampered away down the hill. Whether he was hit or not was hard to tell, but he was so flurried that he seemed to roll himself into a ball and disappeared down the hillside like a stone, head over heels, bounding from point to point and disappearing into a dense mass of brushwood, far down the declivity and close to the edge of the torrent below. Bears seem to adopt this method of progression when they get nervous from being suddenly disturbed or shot at. I have seen one drop out of a high tree without hesitation, and they do not seem to mind the fall in the least.

Returning to camp, we found that the sun had been melting the snow above the tents in a jocose manner-in fact, rolling down huge snowballs at us, some of which had accumulated in their descent to masses of a ton

* This wild sheep is described by Jerdon as the Ovis nahura: smooth horns, rounded, directed upwards, backwards, and outwards with a semicircular sweep, then the rounded points are recurved forwards and inwards. 
weight or more as they rolled down the snow slope, and continued their course on the bare ground right past the tents, threatening destruction to the frail structures. Luckily the snowballing ceased at nightfall owing to the frost, so that we could sleep without fear of finding ourselves buried under an avalanche.

Next day we returned towards Garbyang, where all was ready for crossing to Hundes. We turned, however, up another valley to the village of Tinkar in Nepal, to await the arrival of our party. There was another village not far off, where, we were told, all the inhabitants had lately died of small-pox and there was not a soul left alive. Tinkar had escaped with no deaths and only a few mild cases. This seemed a miraculous story, but was accounted for when we were told by the Bhotias that the vaccination officer sent by our Government had vaccinated all the Tinkar folk, but the old women of the other village had steadily refused to admit the officer or allow him to operate. The goddess Kali could not be propitiated by such a stupid process as inoculating with the blood of a calf. Now, however, the intelligent Bhotias of Tinkar had the laugh over the worshippers of malignant spirits, and every village around was sending requests to the vaccination officer to come over into Nepal and administer the life-saving virus. It was terrible to see the horrible marks that this fell disease had left from time to time on the poor people in some of the hill valleys, faces so disfigured by pits and scars as to seem scarcely human, not to speak of blindness and loss of noses. The stories told of the horrors of small-pox were quite harrowing, and there was but one opinion among all, whether Kumaonis, Bhotias, or Hunias, that the vaccination officer was the saviour of the lives of thousands; and the blessing of the poor was ever being given to 
the Sirkar, or Government, for sending him among them.

The villagers at Tinkar came out to meet us, and presented an offering of a goat and milk. These poor Nepali villagers also supplied firewood, and were loud in their praises of the Government and the sahibs as garib parwari (protectors of the poor). Smyth and I started at 4 a.m. the next morning to climb the grassy slopes above the village where the burrhel frequented, as we wanted mutton for our camp use. It was a hard climb, as the elevation was over I6,000 feet, and between the ridges there lay beds of snow which had to be crossed one after another. As each ridge was topped great caution was taken to scan the next ones with glasses for the blue-gray forms of the wild sheep, scarcely distinguishable from the weather-worn and lichen-covered rocks and shingly slopes. The use of two alpenstocks with iron spikes was not to be despised. The shikaris carried the rifles, and were most keen and excited to make a good stalk. There was only one chance, and it was a female that was shot. The effect of the high elevation and want of breakfast was a frightful headache over the brows, something like what is experienced in a very crowded room where the air is deficient in oxygen. The rest of our party met us at noon for breakfast, in a valley on the track by which the coolies were toiling upwards.

Having enjoyed a good meal and delicious tea with goat's milk, we were again starting, when Munnoo, who had asked for my binoculars, suddenly and with eager excitement, after the manner of these shikaris, pointed out a herd of old ram burrhel lying some $\mathrm{I}, 500$ feet above us. Forgetting that I had already been climbing those cliffs since 4 a.m., Munnoo and I and another shikari crossed a slender snow bridge, and faced the ascent up a 
hollow which would bring us to the back of a ridge close to the burrhel, the air being on the move across from them to us. It took over an hour to reach the particular pointed rock we had noted. Over this Munnoo was not long in verifying our position as just opposite to where the herd still lay quietly. Having rested a moment to allay the unsteady panting caused by the quick climb, I had the satisfaction of seeing fifteen old rams lying asleep, most of them with their heads resting on the ground, and not seventy yards off. Recollecting that one is terribly apt to fire high at these close distances, and having picked the heaviest head, I slipped the point of my double rifle, a I6-bore Jacob, over the rock; and, being perfectly steady and cool, he dropped to a shot in the neck. Terrified at the report, they sprung to their feet, and, not knowing whence the danger came, stood for a second, when another big ram fell to the second barrel. Munnoo, who lay behind me, handed the second rifle; and, still in doubt, the herd started to run in all directions, some actually towards me, and passed within twenty yards below me. A third was hit behind the shoulder as they galloped by, and the fourth bullet went high. So I had succeeded in killing three rams with four barrels, and securing a very nice lot of mutton for the men to eat, and some good heads, the biggest with horns I5 inches long and II inches girth.

The rams are found at this season separate from the ewes, as in the case of the thar. The burrhel is not a forest animal ; he lives entirely on the grassy hills above the tree-line, and grazes on the slopes, retreating to more precipitous ground when disturbed. He can move on the face of the most dangerous crags quite as freely as the wild goats.

We sloped along the upper levels towards the trail, 
and found the camp pitched in a flat, with snow lying all round and mist drifting up from the south. The south-west monsoon was about now due, and we were enveloped soon in dense clouds, with a warm damp breeze blowing up from the plains of India. We were close to the summit of the great range, and to-morrow we were to cross the frontier. 


\section{CHAPTER X}

HUNDACE OR HUNDES: THE LAND OF THE HUNS

THE sixty Bhotia carriers, hardy, strong, well clad mountaineers, all wearing thick gray woollen clothing with good native-made shoes or Hunia boots, grouped under rocks round the tents, had lighted fires, and were cooking strips of burrhel meat and boiling coppers of rice. The yaks and ponies were grazing close by on the short grass, and Jussoo was at the tent door discussing the chances of our crossing on the morrow without being obstructed by the Hunias. They had given out that the sahibs were gone into Nepal to shoot. Soon all the men, tired with the weight of their loads, wrapped themselves in their thick goats' hair blankets and lay all round the tents. At early morn we were on the move, and soon got on to snow, the last ascent being steep but by no means difficult. The yaks were driven on ahead along the face of the snow slopes, an old cow leading. She smelt her way on the safest and most solid snow, by instinct choosing the places where the surface was sound, and the others followed in her footsteps. By the time these heavy animals had passed there was as fine a flight of solid steps cut in the snow as could be made by the best ice-axe man, and no one sank in or even got wet feet. The difficulties of Alpine climbing as usually described by mountaineers are thus very much simplified.

No one had crossed the Tinkar Pass this year, and the 
path had to be found. But barring the great labour of walking at an elevation of nearly 18,000 feet, there was not much difficulty and no danger. Some of the bearers became exhausted under their heavy loads, and some were sick, and all complained of headaches. Goggles over the eyes were necessary; or strips of black crape, which we brought for the men, were worn tied over the eyes. A few, who had not recovered from the big drink to celebrate the start from their homes, threw down their loads and declined to proceed; but, acting as rearguard, I was provided with a flask of brandy carried on my saddle pony, which brought the laggards to the scratch. The native opinion is that there is poison in the air at these high elevations, and they have a great dread of the mountain sickness which generally affects people. With me it only took the form of headache and a singing in the ears; but with some it seemed to cause prostration and vomiting and bleeding from ears and nose.

Following the track in cloud and damp mist and snow, by ten o'clock we found ourselves all safe at the summit, and for a moment the cloud cleared away. Looking back, a wonderful view of dark valleys opened under our feet, with distant ranges melting away in the blue, hazy distance, and valleys traced out on the distant map, giant peaks of white quartz rock or snow standing in blocks, over the top of which we could see out into the far, far, hazy, dim distance where lay the sultry plains of Hindustan. Above these drifted up perpetually from the south a canopy of white, fleecy clouds, which struck the highest summits of the Himalayas and then tumbled over to the other side. But, strange to say, the endless phalanxes of soft white vapour, in falling over the rim, as it were, melted away suddenly into invisibility, and to the north was a clear blue sky without_a cloud,_and a fierce blaze of vertical 
sunshine. No words can describe the transformation scene which the view northward presented.

The contrast was surprising and startling. Sloping away gradually northward from the summits there were gently rounded hills, smoothed and levelled off almost like plains. To the south the best roads were but dangerous tracks, where the most sure-footed might slip or fall down into depths unseen. To the north there was an endless stretch of smooth surface, where a coach and four might be driven without fear of an upsét. To the south was a climate where the rainfall for half the year was 200 to 300 inches, and the snow line was about I6,000 feet above the sea. To the north was an almost rainless climate, with a snow line at an elevation of r9,0oo to 20,000 feet. Towards India was dense forest, and vegetation covering every spot and clinging to every hillside where a bush or a blade of grass could grow. To the north there was not a tree in a thousand miles, or perhaps ten thousand, not a bush to be seen, scarce a blade of grassnothing but stones, gravel, shingle, or clay. To the south you could not see the soil for its dense parasitic clothing of vegetation, green and blue, stretching to eternity under a deep and sombre canopy. To the north not a scrap of green in the whole landscape-nothing but brilliant crude red and yellow and purple and white, dazzlingly marbled out under a blazing sun. Lastly, to the south lay a region of rivers and torrents, noisy streams and cascades, perpetually roaring and cutting up the soil into an endless network of deep ravines and watercourses, while to the north there lay vast and arid plains where (except from scantily melting snow) no water was to be found; the beds of streams could be seen but rarely and they were often dry, and what rivers were found flowed gently and with feeble current. 
To linger on this lofty ridge of the world, which we had reached by such weeks of toilsome climbing, and wonder at the greatness and appalling grandeur of the scene, was an absolute necessity. A moment to be never forgotten, and a position attained by a very few mortals. Turning at last to follow the party now cheerfully trudging on the downward slope, it was a delight to emerge into the bright sunshine and warmth, and soon to descend from glacier and dazzling snow on to solid ground and firm going, where one could mount one's pony and start galloping at once. Soon catching up the party, we proceeded gaily. The order was given for no straggling. All to keep close together, driving the yaks in front. Not a sign was to be seen of the sixty Hunia horse-soldiers we were told had been sent to stop us. We had evidently hoodwinked the authorities on the frontier. We saw only the tracks of a couple of horsemen who had recently been patrolling the pass. The distant view was enchanting: a great extent of gaily coloured rolling downs, with distant ranges of hills standing in rows one after the other, with deep blue shadows on their sides; and north-east was a glorious peaked snow mountain, with four subsidiary peaks showing against the sky. This was the never explored Gurla Mandhata, 25,500 feet high, where the snow line only commences at about 19,000 feet elevation.

In front of us to the north-west we could see something like houses on top of a pointed hill, and the walls of a fort. This was Taklakhar, the frontier military station and fort, and seat of a large lamaserai. Coming to lower lands where yak droppings lay about well baked in the sun, we soon collected enough to light a fire and boil the kettle and make tea, and sat down to an excellent breakfast. Our khansamah and cook, who, being plainsmen, had to be taken care of, had ridden most of the way on yaks, 
and were fit for their important duties. The Bhotias all carried bags of sattu, or parched corn, which they could eat in handfuls quickly without having to cook. It was partially roasted and browned, and was not at all unpalatable, and more digestible than semi-boiled rice. Many had suffered agonies the previous evening from eating rice, which, though boiled for hours, could not be properly cooked owing to the rarefaction of the air, water boiling at a temperature of $180^{\circ}$ instead of $212^{\circ}$ Fahr. The rice naturally swelled in the stomach after being eaten, and the result was howling and kicking all through the night. Proceeding on our march, and gradually descending, we got nearer to Taklakhar. Presently we saw from a distance a troop of horsemen coming at a hand-gallop straight for our line of march, as if they came from the Bians Pass, where, as we heard later, they had been sent by the Zung-pun, and had been waiting to stop our passage, as they had done the year before, when Smyth had tried to get across. He had had only a few carriers, and his loads were carried on jhobus. The Hunias had simply unloaded the jhobus and turned them loose. They had succeeded in stopping him, as he could not leave his loads; and he had to return the way he came, being quite helpless. Such tactics were on this occasion of no avail ; and we felt, with our sixty faithful Bhotias marching in a solid body, with the yaks in the middle, and headed by four sahibs and six shikaris, all carrying rifles, guns, and revolvers, loaded with near a hundred cartridges, that we rather had the advantage of these gentlemen.

Their advance was intended, doubtless, to be terrifying and imposing, as they swept on in an extended line, shouting and brandishing their weapons, fully sixty specimens of the Hunia cavalry wheeling in picturesque confusion 
right in front of our line of march. If the exhibition was a brave one, it certainly had the wrong effect on us; for so funny and quaint a crowd of little hump-backed, broad-cheeked, greasy bundles of dirty clothes, calling themselves sowars, and mounted on shaggy little ewenecked, ragged-hipped ponies, with long manes and tails streaming in the wind, the trappings held together by bits of string, never was seen before. We simply stood still and roared with laughter. Their open countenances, without a particle of beard, and slit eyes and squat noses, and pigtails flying behind, and hair plastered down each side, like a woman of the early Victorian period, were too irresistibly provocative of laughter. They tried hard to look ferocious, but soon catching the infection from us, they began to grin all over, and ended by laughing heartily and enjoying the fun, and putting out their long red tongues in rows, which started us laughing more furiously. This is the recognised form of friendly salute among the Hunias. It takes the place of hand-shaking, and I believe one is expected to do likewise, and touch tongues, a part of the ceremony we felt inclined to omit.

For a description of the Huns of the old Scythian family it is only necessary to refer to Gibbon. He shows that they were little and deformed men with flat noses and no beards, big heads, 'broad shoulders, and a short, square body of nervous strength, though of a disproportioned form,'* that they marched incredible distances mounted on small horses, and under Attila overran the whole of Europe. Learned writers have endeavoured to locate the origin of this people. Strange to say, they seem to have placed it everywhere but in the place which is called at this day Hundace, or Hundes, the country of the Huns. Here we had an actual exhibition in modern real

* Gibbon's 'Decline and Fall of the Roman Empire,' chap. xxxiv. 
life of the advance of the once dreaded army of the Huns described by Gibbon.

These quaint barbarians in round felt hats, armed with swords like old Roman gladii, bows and spears-a few of them carrying slung across their backs long matchlocks with a sort of easel attached to rest the point on when firing - were (but for the matchlock) probably exact counterparts of Attila's heroes. They are a very lazy race, and never go two yards on foot. Their walk is a slouching, feeble one when off their ponies, but when mounted they are in their glory. They ride on high wooden saddles, with boards for flaps. Over all is placed a sort of padded mattress which covers half the pony. They scuttle along over the stones at a tremendous pace, the gentleman on top jumping and winking and nodding at every step of his prancing charger, which is held by a powerful bit. There are brass mountings and tassels of red hair swinging from the bridle, and cruppers and breast-bands galore. His riding-boots are of red cloth of a graceless shape. And in the matter of hats he is most tasteful. Some are broad like a Swiss woman's, some tall like the Welsh, some are wideawakes and soft felt caps, some Glengarries, like soup-plates with a pompon in bright yellow or scarlet in the middle. This on the top of a greasy round red face and an enormous pigtail behind makes him too funny an object. His knees are up to his chin, in the Tod Sloan fashion. He brandishes a short dog whip, and makes his pony pace with an extraordinary pig-like run, two legs on one side moving together, then the other two.

These brave troopers did not, however, succeed in making us stop our march, as when they got in front of us we laughed the harder at their uncouth gestures, and walked round them, telling them through our inter- 
preters that we had no time to talk and must get to the end of our march. They would draw off for a bit and then repeat the intimidating performance, which was quite as good as a play and very entertaining.

Our great endeavour was to get to the bridge which spanned the Koriali river, and across it, so that they should not stop us before coming to camp under the heights of Taklakhar, which, after going a few miles further, we approached. As we pressed on to descend some shingle banks down to the river, we were suddenly intercepted by about 200 foot-soldiers or men from the fort, who threw themselves in front of us in a compact body, shouting with shrill, strange voices and making signs to us as if frantic. Some lay on the ground before us, imploring us to stop, and drawing their hands rapidly across their necks; whether this was intended as a threat or some freemason's sign we could not tell, but Jussoo and Boodoo begged us not to use our arms, and gesticulated and argued with a confused babel of tongues. Some stones began to fly, and we made a rush for the bridge; but before we could reach it these yelling maniacs had hurled down the timbers that formed the bridge, and we could do nothing. Jussoo interpreted that they had strict orders from Lhasa that no one was to go by, and that if we forced our way their heads would be cut off, which the sawing motion at the neck was intended to express. Mr. Drummond and Colonel Smyth assembled our whole party on a mound, where we held forth by our interpreters that we were friendly travellers and did not desire to do them any harm; at the same time that, if any violence was attempted, we were well armed, and prepared to defend ourselves and property. That in pulling down the bridge and preventing us from reaching our camping-ground they had 
committed an unfriendly act, to atone for which they would be required to bring us fuel and supplies, for which we would pay.

The excitement having subsided, we soon pitched tents on the flat place above the river, which ran in a deep channel between beds of rock.

The fort and town of Taklakhar was perched on a high ridge or summit opposite, overhanging the Koriali river. There was a zigzag path ascending from the base some 300 feet up the face of the cliff, protected by curtain walls; and above were some very high buildings with many windows crowning the height, resembling somewhat an Italian town and convent. There were many caves to be seen in the face of the rock, which were said to be caves of hermits or very holy lamas. Jussoo, having gone to the town, soon returned with men bringing flour and rice and firing, and peace seemed quite restored.

Next day we had a visit from the Zung-pun, the commandant of the fort,* and soldiers under the Lhasa Government. Also the 'Bara Lama,' or head of the Lamaserai, a gentleman who seemed of much importance. Mr. Drummond received them sitting inside the tent in a chair, the symbol of the Indian Sirkar, while we sat round him, and the Hunia gentlemen sat on the ground and our two Bhotias at the tent door. They professed their friendliness to the Indian Raj and the British sahibs, but declared their inability to let us enter their country, owing to strict orders from headquarters. They repeated the story of the indiarubber boat and the profanation of the sacred lake, and the consequent decapitation of the previous Zung-pun. We declared that we did not desire to offend their religious prejudices, and should on no

* Sometimes called Nirbah, oftener Zung-pun. 
account go near the lake or the sacred mountain of Kailas; that we only desired to travel peaceably in their country and enjoy the chase of wild animals, of which we heard there were plenty; and that, as we only carried provisions for thirty days, we were bound to come back by the same route in that time.

The Zung-pun had one long earring in his left ear, 3 inches long, formed out of a blue-green turquoise stone, and wore a peculiarly shaped bonnet of thick felt. The lama was like a monk, in a long coat of deep red cloth, with a cowl over the head, a rope round his waist, and beads like any rosary, with crosses. He carried a brass praying machine, which he kept winding at times from left to right, for fear at any time an interval without prayer might endanger his soul's welfare, while he was engaged in worldly affairs or in conversing with infidels. The Zung-pun did most of the talking, but deferred always to the spiritual authority for his consent or approval. He informed us that we might stay where our camp stood, and that he would send out shikaris into the jungle, who would kill game for us and bring us the skins and horns. We thanked him for his kind offer, but said we intended to do our own shikar. The lama, though not professing Christian virtues, seemed not to object to Christian beverages; for when presently a servant placed glasses and a bottle of J. J. Jameson's whisky on the table, his eyes, which had remained expressionless, seemed to recognise the brand and twinkled affectionately. $\mathrm{He}$ did not refuse to partake of a drop, and even produced his own drinking vessel, a wooden bowl, from inside his capacious breast pocket, as if he had anticipated the entertainment. The Nirbah, having also partaken, became quite profuse in his offers of supplies and all that we might require, and told us that he would give 
our requests his most careful consideration and let us know his decision later on.

After they had departed, mounted on ponies caparisoned in a gaudy manner with coloured saddle-cloths and tassels of yak's hair-for they never walk a yard unnecessarily-there came half the population of Taklakhar in relays to our tent doors, to inspect our kit and satisfy their curiosity. The monastic element seemed to preponderate; and lamas of all grades and equal dirtiness came in troops, all using praying machines, some of which we purchased. They are round brass boxes with a handle, and a weight which swings the box round on the handle. Inside, the prayers are written on hundreds of strips of paper. The prayers, to be effective, must on no account be twisted the wrong way. There came also women, who were so like the men as to be undistinguishable; but many had black smudges over their cheeks, so as not to attract admiration too generally. They were quite ugly enough without trying to disfigure themselves further. Nature had made them hideous, with broad red cheeks and squat noses. The children were jolly, laughing, little bundles of rags, like their parents. Whether they kill their female children or not, it is a fact that women are in a great minority among these Huns, a circumstance also noted by Gibbon.

Next day the Zung-pun agreed to let us go for one month's trip north-east, provided we promised not to go near Manasarowar; but, to protect himself, he said we must put up the bridge ourselves and pretend to have a great fight, so that he should be able to report his being overpowered by numbers. The whisky was again drawn upon, and we presented the lama with a piece of scarlet broadcloth sufficient for a full coat, and the Nirbah with some gunpowder. They were much pleased, and became 
quite friendly and jocose, laughing freely and putting out their tongues. They were curious to know about railways and telegraphs, and asked after the Queen of England. We inquired why they were so anxious to prevent British subjects from visiting their country. They replied that it was the order of their Government in Lhasa, and that the jungle was infested by bad people called Khampa log, who robbed and murdered any travellers they could meet. The distance to Lhasa was about thirty marches for men on horseback, but double that for jhobus, and the roads very bad. It could not be less than 600 miles. Before parting, the Zung-pun presented us with little gifts. I still possess a brass tassel with horsehair, used for hanging to a horse's bridle.

The garrison of the fort was said to be about 300 men, of whom Ioo were horse-soldiers, so called, and the authority of the Zung-pun extended over a considerable area. They spent the summer in tents, herding their sheep. goats, and jhobus all over the vast plains, moving higher as the sun got stronger and the grass grew. In the winter it became deadly cold, and the shepherds moved down from the higher plateaux into valleys further north and east, and into houses. It did not snow much, but the winds were so cold and frost so intense that no one could live out in the jungle in the cold season. The wool of the white goat was carried on jhobus to Kashmir for making shawls, and the pashm from goats and sheep was also traded for flour and rice, which would not grow in Hundes. Such information was freely given us. Our interpreters did not recommend our entering the town or fort of Taklakhar, which, from the size of the buildings on top of the hill, must be a considerable place. They could not answer for our being civilly received; indeed they seemed to have a dislike of 
foreigners entering their houses or temples, and the lamas had a sulky manner. So we refrained from going near their temples or conventual buildings, and remained very good friends. Their religion is perhaps the oldest and most spiritual in existence; their ten commandments as much worthy of respect as the Jewish Decalogue; their doctrines of monotheism and incarnation and the efficacy of repeated prayer corresponding with Christianity; their priestly and monastic institutions being practically identical. Yet, compared with its great rivals, Christianity and Islamism, Buddhism takes precedence as to the date of its origin and the extent of the influence and power of its dogma. Here we have a country which has remained unique as the only one on the now well ransacked globe where British or European explorers have not poked their noses; until recently untrodden by the feet of geographers, geologists, ethnologists, or anthropologists, and all the other 'gists' who want to know everything. Yet it is a country which produced the greatest conquerors, probably the oldest civilization and religion which still exist, and the most unchanged and unchangeable people; a country also most interesting in its natural conformation, as the land of the highest mountains and the loftiest tablelands in the whole world. 


\section{CHAPTER XI}

GURLA MANDHATA AND THE SOURCES OF THE

BRAHMAPUTRA

THE rays of a bright morning sun had scarcely risen over the tops of the hills which flanked the valley of the Koriali* river, when the sound of sharp firing echoed from the rocks opposite, and round the face of the crag on which the fortress of Taklakhar stood. Some of the Bhotias had gone up stream before daylight and crossed at a ford, and were now busy hauling with ropes to replace the beams which formed the bridge. The inhabitants rushed out from the town, but kept a very respectful distance. The blue rock pigeons, which roosted on ledges of rock above the water, flew out in flocks and were knocked over, so that our powder was not quite wasted; while the Hunias seemed the more convinced how useless it would be to resist our advance, and might depose with a good conscience that the sahibs were too well armed, and had outwitted them and beaten them in the fight. Anyhow the bridge was restored, consisting of three or four beams laid from ledge of rock to ledge, in a narrow place where the stream had cut a deep channel, and tied together with ropes to prevent them from separating.

* Written in some maps 'Karnali.' After piercing the snowy range, it comes out through Nepal as the Gogra to join the Ganges at Chapra. 
On this rickety structure our party filed across, jhobus, ponies, carriers, and all in safety; while the Hunias looked on, gesticulating and shouting, but offering no resistance.

We had now a free hand to explore the unknown country before us, where Colonel Smyth had never been able to go, and where Mr. Drummond on his previous trip had not reached. We determined to strike in a north-east direction. Jussoo informed us that there was a pass over the great range which we could see in that direction, across the eastern shoulder of Gurla Mandhata, which would bring us out on to the countries east of Manasarowar, where were extensive jungles, frequented by few natives and famous as the haunt of the rarest of all animals, the bos grmmiens - 'ban chowr,' or wild yak. Colonel Smyth on his previous expeditions, further west from our present ground, had shot several old bulls and sent the skins to England, where they still are to be seen in the British Museum and at Manchester and in other museums; but he had always been told that further east across the second range, north-eastward, was the home of the wild yak, where herds of considerable numbers were said by the natives to exist, but the country was jungle, and wild and dangerous to enter. The rivers did not run into the sacred Ganga, but belonged to the bad country, so said the dwellers on the Indian frontier, and they dreaded to go eastward; but Jussoo and his sixty Bhotias had agreed to come as far as we could get while our supplies held out. We had flour and rice for thirty days, and expected to supply our larder with meat enough.

Our first march brought us over rolling hills cut up by wide valleys. We followed one which trended in the right direction, and our guides informed us that a road 
could be found over a very high pass called Dak Eo, between great walls of rock. The name in local language meant the 'Gate of Death.' If we could pass by this ghat to the real plains of Tibet, we should save about ten marches by not going round to the west of Gurla Mandhata by the usual trade route and past the Manasarowar lake, which we wished to avoid. The weather was extremely fine. Bright sun nearly overhead, deep blue sky, fleeced by a few white clouds; and for some time snow had not fallen on the heights. We pushed on rapidly, and made about eighteen miles, coming to camp in an open valley with a winding stream over sand and gravel, edged by short grass where our animals might graze. We had collected yak droppings and some roots of a small prickly bush like a broom, and soon had fires burning. There were overhanging rocks where the men had shelter and made themselves comfortable. We were escorted by two Hunias, soldiers so called, on ponies, who made their own camp not far off. They were jolly, harmless fellows, who gave us no trouble, and squatted on the ground and played some game like dominoes, and munched sattu (parched grain), which they carried in greasy-looking bags. They were sent by the Zung-pun to watch our movements, and report our whereabouts if we went where we were likely to bring trouble.

This march was an agreeable one. The sharp breeze kept us cool enough, though the sun's rays were roasting. We boiled the thermometer, and found our camp to be about I6,00o feet. The hills were quite bare, rock and stones; but in the valleys you could see blades of grass growing in clusters among the shingle, of a kind called 'bhuk' grass by the Bhotias (bhuk meaning hungry), because all animals get hungry when they see it, and stop to take a bite. Our ponies when we rode them used to 
rush for every clump and take a mouthful. It was a sort of 'sheep fescue' grass like the Festuca ovina of Europe.

Here for the first time we saw the kiang, or wild horse. Several herds came to look at us as we marched, and galloped around, neighing and kicking up, but kept a respectful distance. They have big ugly heads, and tails and ears like mules, and a black stripe down the back; colour light bay with white noses. They have fine free action in the trot and gallop, and are fourteen to fifteen hands high, strong in the leg, and heavy in the body. We also were frequently saluted by marmots,* which screeched at us from their earths, standing on their tails, but nearly always scuttling into their holes before one could get a shot. They are not bad to eat, and have nice yellow skins.

Next day we marched twelve miles to the entrance of the pass. Here the country became wilder, snow-clad hills shining in their spotless whiteness against the sky, and we got glimpses of the five peaks of Gurla Mandhata towering to our left.

We ascended gradually and camped by a stream in a valley below the snow. Elevation by the thermometer over I8,00o feet. The animals had but scant pasturage, and the carriers were much exhausted. They cooked themselves, however, a good meal in preparation for the next day, which was to be a long march over the pass. The night was fine but cold (about $25^{\circ}$ Fahrenheit), and we struck camp at 5 a.m., soon getting on to snow, which

* Described as Arctomys hemachalamus by Jerdon. It is larger than the marmot of the Alps, and fully double the size of the American prairie marmot. I have seen the three species in their native haunts, and, except in the matter of size, they are very much alike. Their burrows are like badger-earths, and they collect grass and make hay and store it underground for the winter. 
was luckily hard, and the ascent became more precipitous. The carriers struggled on manfully under their heavy loads, but walking even without anything to carry was at this high elevation most distressing. Many sat down on the snow and declared their last day was come; but the Bhotias are fine, plucky mountaineers and fought it out well; a nip of brandy set the weak ones all right, and they knew that delay would be fatal. The sky was clouded over, but the day held up well. Sunshine would have been worse, as it would have softened the snow. The danger is of getting into deep and soft snow, and remaining there. If we had been in Switzerland, crossing steep snow slopes and crevasses covered with snow, with all the paraphernalia of ice-axes and ropes, we should have had a long story to tell; but the instinct of the yaks, which went on steadily up and up, picking their way round the ledges of glaciers and under rock crags, seemed never at fault. Their feet are formed to open wide and not sink in soft snow; and when a dozen of them have gone safely ahead, the men and, last of all, ponies followed on the well-pressed snow tracks. We kept on mounting steadily, but it was not till 2 p.m. that we reached the highest point, a ghat or passage between high walls of black basaltic rock, a veritable gate of death. Here we halted till stragglers came up, and boiled some tea on a lamp, and also the thermometer, which gave close on 20,000 feet. It was an exciting moment to have gained this great elevation. The scene was most weird, and the view of peaks and glaciers when the cloud occasionally lifted was stupendous and bewildering. Goggles, of course, had to be worn, but some of the carriers who had neglected to tie on their crape bandages were howling with pain and half blind. Some, too, were very sick, but a short halt and the commencing to descend put them in 
spirits again. One or two plainsmen there were completely hors de combat, shivering and chattering with cold. They had to take a turn on yaks or ponies.

There was just above us a rocky peak from which a better view could be got, so Hodgson and I started to climb it. There were great rocks lying on one another, perfectly clean and freshly fractured, without lichen or stain of any sort, some balanced so that they moved when trod upon, though many tons in weight. How did they get broken, and what force of Nature placed them there as if neatly deposited the day before, sharp from the quarry? How many thousand years had those fragments of rock been there braving the storms and frosts? There was no higher place for them to fall from; they were themselves the top summit of a small rocky needle. Looking suddenly through a rift in the clouds somewhere we had not come from, we saw a lake, black as pitch, its dismal surface rippled gently by a curling breeze, and in it were floating islands and glistening icebergs. Beyond was a wall of black, clear ice, going sheer down into the lake, and going up, up to the clouds. Could anything living exist under the shadow of that vast cliff? The rocks trembled under our feet, and terror seized us involuntarily that a great catastrophe was near. Suddenly the ice wall seemed to be sinking like the curtain of a theatre. There came a sough of cold, clammy wind in our faces. There was a cracking and a roar, and the sound of billows raging. The lake seemed to rise and surge up to where we stood, and the iceberg to sink into the watery depths below. We were surprised to find the rocks still balanced true under our feet, and that we were standing safely, though scarcely daring to advance or go back. We even forgot which side we had mounted from, while all was again lost in dense cloud, 
which swept past us like a London fog. Presently we heard the shouts of men calling to us from far below, so we gladly faced towards the sound and hurried without speaking from rock to rock, springing downwards as if the devil were behind. The great stones played different notes under our feet as they clinked and rocked. At last we regained the beaten snow track, and rushed wildly forward till we overtook the rest of our party, who were wondering where we could have got to. They were glad to see us, but not as glad as we were to have got safely off that pinnacle. We looked at one another, and thought more than we wished to say.

The snow line in Tibet is so much higher than anywhere else, and the climate so dry, that I think an ascent of such a peak as Gurla Mandhata, 25,60o feet, would be more likely to be successful, if any person cared enough to try, than the ascent of Chimborazo, or any of the Himalayan giants.* I confess I should not want to go up, but at 20,000 feet I did not find breathing too difficult. One's pulse certainly goes very much faster, owing to the oxygen being thin, for blood must be oxidized. In fact, during the three months I was in the heights my pulse was steadily over Ioo, night and day. We got used to the rarefied air, and did not have what they call mountain sickness in America, which is like a high fever. At least, we suffered less from it each ascent we made, and on this occasion the headache and pressure over the temples passed off as we descended. Certainly this camp was a

* The ascent of the high mountain, Mustagh Ata, in Northern Tibet, was attempted several times by Dr. Sven Hedin; but though he was accompanied by most excellent mountaineers of Kirghiz race, who did their very utmost to scale this lofty snow pyramid, riding all the way on strong fresh yaks so as to escape the exhaustion of climbing in such a rarefied atmosphere, they found it impossible to get higher than about 22,000 feet. 
very uncomfortable one, and between wet, cold feet from melted snow, and want of fire, and little to eat, and that half-cooked, we did not sleep much. A good sheepskin coat with the wool inside kept one pretty warm, and long boots worn over three pairs of woollen stockings had kept me dry while crossing the snow; but when we came to camp on the first bare ground below the snow line where a few wild yak droppings were found, it became very chilly. The tents were pitched on wet ground, and fires would not burn well. Some soup and lukewarm tea helped to restore us, and we tried to get warm with the aid of thick blankets. The march had been a long and trying one-sixteen hours over snow on very little foodand all were thoroughly worn out and miserable, and too weary to sleep.

Daylight saw us on the move again. We were still very high up-about r9,00o feet by the thermometer, boiled over a lamp. The animals had nothing to eat. The yaks grunted after their peculiar manner, entirely different from the lowing of an ox or cow. They are a distinct species, some people say, and not related to the Indian cattle, which are smooth-skinned and white, and have a hump on the withers. The yak is unlike in every particular, being covered with long black hair, and having a fringe and bushy tail reaching to the ground ; but they will breed together, and the cross is much used for carrying loads and called a jhobu. He takes most after the yak, and can scarcely be distinguished from one, and will breed again.* Here we were arrived at one of the corners of the world where a wild ox exists, and appar-

* As I understand him, Sir R. Strachey states, in his recently published account of the Manasarowar lake country, that jhobu cows will breed with a yak bull, but not with a jhobu bull, and that the jhobu is the cross of yak cows and a Brahmini bull. 
ently a very distinct and rare one, remarkable for his size and imposing appearance and his beautiful black silky coat, with long hair hanging down to his feet and an under-coat of pashm, or close soft wool, without which no animal could endure the winter cold. All the animals of this plateau possess an under-coat of pashm-sheep, goats, and even dogs.

We had now come out on the watershed of the Brahmaputra, having crossed the range which lies to the north of the Himalayas. Descending rapidly to the northward, we found wide valleys and grassy flats opening out, and all the streams trending towards the east. Jussoo informed us that they flowed into a great river which ran towards Lhasa, and that now we were in a vast and unfrequented jungle or wild country, the home of the ban chowr, or wild yak. We pushed on, to reach before dark some grassy plains, where scanty vegetation and bushes of broom were scattered over the gravelly soil, and a clear stream wound its way over pebbly shallows. Here we pitched our camp, and fires were lighted and the animals turned out to graze. The ground was strewed with the droppings of enormous bulls, and their great tracks, ro inches across, could be seen everywhere. Colonel Smyth, who had shot the wild yak before in mountains further west, advised us not to approach old solitary bulls incautiously, as they would certainly charge, and, above all things, to aim low in the chest, or behind the shoulder, where the heart lay. The shikaris were ordered to keep a sharp look-out on hills around, and soon reported that a black object was visible. The binoculars revealed a fine bull grazing in a side valley. Soon Hodgson and I were off with two loaded rifles each. The excitement when we made our stalk, each along the back of a separate ridge, was succeeded by the wildest 
despair. The bull got the wind from my side, and started to trot up the side of Hodgson's ridge, straight, as I could see, for where he was walking, quite in ignorance that he was so near, as each was concealed from the other by some big rocks. I beckoned Hodgson to look out, and immediately they came face to face at about forty yards. Alas! he followed recent advice too well, for his bullet struck too low, going through the long black fringe of hair right out under the chest. The great beast, astonished at the unexpected meeting and the report of the rifle, rushed headlong down the slope, disappearing behind the rocks, and got clean away, untouched, into the next valley, where we never saw him again.

When disturbed the yaks will run for miles, generally retreating upwards to high ridges above the snow line, which are unfrequented and almost inaccessible. They prefer during the heat of the day to be on the snow, and come down to graze at night. During the next week Hodgson and I continued to hunt all the valleys for miles for yak, while Colonel Smyth went off north-east and Mr. Drummond eastward after antelope and Ovis Ammon. We came each day on herds of wild yak grazing in the early mornings in secluded valleys, as many as $I_{50}$ females and calves together. We would sight the black objects dotted over the slopes, some grazing, some lying down; but their position was so cleverly chosen that it proved impossible to approach them. We made détours of miles and miles, mounted on our ponies when the ground was good enough; and when at last we tried to stalk them, either an old sentinel cow, placed to watch the top of the valley, would be before us and give notice to the rest of the herd, or the wind would shift and blow from us to them, or the ground would prove too level for possible concealment, and the herd would simply move off 
over a high ridge and disappear from view among clouds and snow-fields. The weather at times was less agreeable, snow and sleet falling; the nights were cold, and the distances we had to travel, often tramping in snow, made us so weary that we were almost worn out, and despaired of securing a specimen and replenishing our exhausted larder. There were no inhabitants of these desolate valleys, where grass was scarce, and that only in hollow places.

There was ridge succeeding ridge, and sloping valleys intervening, all so like one another that it was hard to distinguish one's locality. The compass had often to be consulted if the great summit of Gurla Mandhata was lost to view, and our shikaris were often in doubt as to our direction, though first-class mountaineers and good trackers. On one occasion we had sighted the big herd in the top of a wide valley, and the shikaris determined to try and drive them to the guns; so we made a grand détour, leaving three men below, and after going round by another valley-a distance which took several hours to compass-we arrived at what seemed to be the only pass by which the herd could leave the valley, and placed ourselves behind rocks. Presently, by arrangement previously made, the three men showed themselves in the valley below, and the herd, becoming alarmed, ran together, and began to face towards us. The wind was blowing, as it usually does by day, up the valley from them to us, and our chances of a good beef-steak looked rosier. Alas for the uncertainty of affairs! The wits of these heavy, big, stupid-looking, lumbering beasts proved sharper than ours; for they sent on an old cow up the ridge, and she by some instinct scented danger, and retreated, with her great black bush of a tail in the air, down again, and away went the whole herd full gallop straight 
up what seemed to be an impossible slope, with a snow cornice at the top overhanging and curling over, which looked like an absolute stopper to man or beast. Not so, however, to the yaks; for they made a hole in the snow, and we had the mortification of seeing the whole herd disappear through it against the sky-line. We fired a few rifle bullets after them out of sheer desperation, but the distance was too great for any result; in fact, our sporting rifles were not built for long range purposes.

On one occasion we crossed another very lofty divide, and found ourselves suddenly out on the northern slopes of another watershed, none other than that of the mighty Indus. Far beneath us, some miles away, lay the most brilliantly beautiful blue sea, the celebrated Manasarowar lake, as it proved, which we had promised not to approach. The foreground was flat, rolling hills and ridges sloping gradually towards the lake, all bare and tinted in most crude colours-reds and pinks and orange-while hundreds of miles to the north and west in the violet distance there stretched range after range of low, jagged hills, all alike, and succeeding one another in endless succession. Conspicuous, and towering above them all, was the snowcapped summit of the sacred Kailas. We sat down for awhile, and munched our biscuits and enjoyed the wonderful and extensive panorama, and sketched it in water colours as a record of our tramp. We could see the flocks and black tents of shepherds scattered over the plains towards the lake, and the air was so clear and rare that objects seemed much nearer than they were. The sun shone bright, and silence reigned over the vast prospect, save for the familiar songs high up overhead of innumerable skylarks, reminding one of scenes far away. The ground, indeed, seemed to be the breeding-place of all the larks in India. Their nests were so numerous that one 
ran the chance of treading on them frequently. Indeed, all the birds and animals except the yaks were quite tame in this strange country. The mother larks would sit within a yard of your feet, and almost let you put your hand on them, and the white hares, which abounded in some places, would sit up and stare at you not five yards off.

Next day we marched a long way eastward along the northern slopes of the Gurla range, following the valley of the Brahmaputra. Here, in the side valleys, we saw tracks of old bulls, and separated to explore fresh country, camping on the ground, with a native yak's hair chaddar stretched over for a tent. I was at last successful in following two old bulls which my men had seen standing on a snow-field late in the evening. At daylight I sent men into all the side valleys to bring word if they were to be seen, and about 8 a.m. they came to say that the old bulls were quietly grazing in a small valley with a lake, not far off. The wind was still blowing down the valley, but would soon change upward; so we hurried on, concealing ourselves behind a line of moraine which swept up the side of the valley. There were two splendid black fellows quietly grazing by the lake. My shikari followed with a second rifle and double gun, also loaded with ball, and we made good our stalk up to within 150 yards. The first shot awoke the echoes from the rocks above, and the bullet-thud was clearly heard. The great hairy bulls, with bloodshot eyes and heads in the air, faced round and made some startled runs, grunting savagely, but stopped short to reconnoitre for their concealed enemy. Five more barrels were emptied, and still they came on, almost up to the rocks where we crouched, frantically loading up and cramming in bullets and ramming them down, for the rifles were old-fashioned muzzle-loaders, 
I4 and I6-bore, loaded with conical bullets and four drachms of powder. The biggest bull had been hit four times, but seemed none the worse, while his companion, also getting a bullet in the chest, thought it wise to retreat up the valley. But the first, discovering his enemy, staggered on, foaming with rage, and fell to the last two barrels, which struck him in the head within a few yards of the moraine. He was game to the last, and was only stopped by weight of lead-a grand beast, seventeen hands at the shoulder, and weighing as much as any prize shorthorn.

Great was the joy of Munnoo, who begged to be allowed to put a bullet in him. He performed the usual halalthroat-cutting, etc. He not being a Mussulman, and unable to repeat the usual prayer for the soul of the animal, the meat would have been useless to people of that persuasion; but there were only two followers of the Prophet in the camp, and they pretended that the halal was all right, like sensible men, and said nothing. The head was cut off with the skin for preserving, and the skin removed and dried. The flesh was cut up in strips and hung by the men to dry in the hot sun; it was coarse and tough, but came useful to the carriers to save flour and rice.

I had sent a message to Hodgson to come and follow the other bull, which had retreated to a deep valley under a glacier. He came next day, and was successful in shooting it. We had several other stalks after big bulls, which haunted the valleys of the range running eastward of Gurla Mandhata. There is a very fine peak called Limi belonging to this range, where some great glaciers exist at the heads of the valleys which debouch into the river flowing towards the east. All these valleys were of a totally distinct character from the precipitous gorges and cañons on the Himalayan side. The climate was 
almost rainless, and there were no deep valleys cut out by torrents; only rounded ridges with flats lying between, and the streams were few and small, depending almost entirely on the melting of the snow. The country further to the east and north opened out into wide plains, sloping gradually to the river Tsampu, which flows eastward. Here were the sources of the great Brahmaputra, originating from the glaciers of Gurla. The trade route from Gartok to Lhasa runs along the main valley. We could see at times the camping-ground of Duksam, where were some tents of the traders, who had yaks, ponies, and many pack-sheep.

On the plains to the south-east we came across camps of the shepherd Hunias, with immense flocks of grazing sheep and goats, who lived in black yak's-hair tents stretched over circular stone-built walls, exactly after the pattern of those of the Arabs in Algiers. These walls were placed in convenient places by some water stream and where grass grew, and were occupied when the sheep and yaks were driven to fresh pastures. We found these people very polite, and they sold us a fat sheep occasionally, and milk and cheese and butter, which last was made up in balls, and sewed into bags of goat-skin with the hairy side inwards. The contents of these bags were so full of hair that the butter had to be melted or combed out with a fork before it could be used, but it was not at all to be despised when eaten with very dry chapatis, and it was excellent for cooking. The cheese was new, white, half-pressed stuff, but, barring the hair, it was not bad. The shepherd women used to milk the sheep morning and evening. They were driven together and tied in long rows to a yak's-hair rope, each with a loop round its neck. Then the women walked down the line with pails, milking the goats and sheep as they came, with a peculiar slapping 
jerk of the hand. The milk was very rich, and a little went a long way in our tea, but it had not the disagreeable taste which goat's and sheep's milk mixed has in the Tyrol, suggesting pig's milk. We occasionally had tea with these primitive pastoral people. We sat on the ground, and the women brought it, very black, in little cups, some of which seemed to be familiar Staffordshire pottery. They offered us tea made in their own method, boiled into a kind of soup, with butter and sugar added and the leaves not extracted. We did not care for this mixture. Everyone carried a flat wooden bowl of turned sycamore or maple, and licked it clean after the meal. They showed us their brick tea, which they said came from China on camels. They would gladly buy Indian tea if cheaper than the Chinese. They also had herds of tame yaks grazing, and we saw one beautiful snow-white bull, which was being taken to some religious ceremony. Its coat was as soft and silky as ermine, and the long fringe and bushy tail were combed out and swept the ground. The white tails are very valuable for making chowries, used by the Nawabs of India to brush the flies away. I purchased two for about fifty rupees, and had them mounted in silver with antelope horns for handles. They all spoke of the Khampa log as robbers, armed with matchlocks, and to be met with on the great plains northward. These people had no arms to speak of, and seemed peaceable and harmless shepherds.

Colonel Smyth and Mr. Drummond explored a considerable extent of country, the former having marched east and northward over the Mariam La. He joined our camp, having shot several fine specimens of the Tibet antelope, $A$. Hodgsoniensis, which we came across on the open plains in herds of ten or twenty. They are not unlike in size and habits to the Indian antelope; but their coats 
are, of course, suitable to the cold climate, very thick and hairy, and their horns are slightly lyre-shaped, but not spiral. We also met the goa, or Tibet gazelle, very frequently. This beautiful little animal is found singly or in pairs, and is very difficult to shoot, being very small and almost impossible to stalk. It frequents flat places, and will not let one approach nearer than two or three hundred yards. Its horns are like the Indian chinkara's, but more slender. Mr. Drummond had met Ovis Ammon, and shot two good rams. The Bhotia carriers having now nearly run short of flour and rice, and being anxious to return to their homes, we started again westward, and by long and rapid marches returned by the pass of Dak Eo to Taklakhar, bringing our trophies of the chase, and without any mishap, except that we nearly lost a man on the pass. Our last camp before crossing was very high up in the same place where we had camped going over.

In the night it came on to snow, and the small tents under which we slept were almost weighed down, and required constant thumping from inside to shake off the snow. In the morning, on looking out, the scene was a desolate one, snow still drifting, and nothing to be seen but white. The snow had fallen ro inches deep, and the men, who slept on the ground covered with their blankets, were completely buried. There were mounds where they lay, like graves. Luckily the snow suddenly ceased, and a general resurrection occurred. We got the loads packed with difficulty and terrible cold hands. Sheep-skin coats were the fashion, and cold victuals. However, after much struggling and arguments among the carriers as to whose load was the heaviest, no one being in too good a temper, we got under way and floundered on in the soft snow. The yaks were, of course, sent ahead to cut a path, which 
they did to perfection; and, indeed, without these sturdy and sagacious animals I doubt whether many of us could have got over so high a pass in deep, fresh snow. But we had a long day and struggled on, arriving at our old camp, where was a stream and sheltering caves and no snow, not before sundown, without a halt the entire day. We were often nearly exhausted from the high elevation and hard tramping, and had to appease our hunger by munching sattu and biscuits. Some men, as usual, got snow-blind, and had to be helped along, for the sun came out fierce and strong right overhead; and when we got to camp and fires were lighted and hot tea made, we felt as if we had been rescued from an anxious position. One unfortunate servant was missing; he was a plainsman, and had been seen very ill on the top of the pass. We called for volunteers to return to rescue him, but few responded. Hodgson and I started with two Bhotias, shouting and moving a light, and went a considerable distance, but had to return without the man. In the morning, which was bright and fine, he turned up all right, having slept, he said, in a cave. We reached Taklakhar without much delay, and said good-bye to our friends the lama and Zung-pun, who presented us with small gifts, and seemed very glad when we finally crossed by the Bians Pass back to the Indian side. The customs of the Buddhists and their praying machines and prayers, 'O mani padmi ho!' and their carving of the sacred formula on every rock and stone which must be passed, always in one direction, left to right-these things have been described frequently in books of travel, from Dr. Hooker's down to the latest, Captain Wellby's, and do not need further recording.

We had found the Hunias a very harmless well-meaning people, and had experienced no difficulties, when once we had come to an agreement with the proper 
authorities, in going as far as we liked to go. We had penetrated a country which few Europeans had ever entered, and crossed over to the watershed of the great unexplored valley of the Brahmaputra. We had shot fine specimens of its very rare game, and gained experience in ascending very high altitudes. We had ascended very high up on the shoulder of one of the most remarkable mountains in the world, the little-known Gurla Mandhata. This conspicuous mountain might appropriately be called the Peak of Asia, as from its glaciers the three great rivers, Indus, Ganges, and Brahmaputra, take their rise-rivers most celebrated in the world's history, and flowing through vast distances and countries to different oceans, and draining the highest and most extensive plateau in the world. 


\section{CHAPTER XII}

PLAINS OF GYANIMA: HOME OF THE 'OVIS AMMON'

THE month of August was now commencing, when the rains in India are still on with all their force. The monsoon or south-west winds blow up from the Indian Ocean, charged with steamy hot vapour, which is deposited as it cools on the southern slopes of the great Himalayan range in the form of a continued downpour. In some portions of the hills a rainfall of 400 inches is recorded in the six months' monsoon, a depth of 25 feet of water over the whole surface of the country. It was not an agreeable season for remaining in the Himalayan valleys, where survey work was impossible. Colonel Smyth having inspected the Bhotia schools in Lower Bians valley, we marched up the upper valley, following the Kali river, with the intention of crossing by the Kuti Pass again into Tibet. Messrs. Drummond and Hodgson returned southward. The upper reaches of the Kali open out into a wide and picturesque valley with grassy slopes, where the Bhotias kept many tame yaks grazing. Smyth purchased eight cows, and we hired nine others to carry our loads. These eight were subsequently sent to England to the Zoological Society in London to be acclimatized. They die in India from the heat, but would do well in Scotland or the Swiss Alps. We camped at the highest village of Kuti, and prepared for the morrow's ascent. These higher 
valleys, resembling the upper valleys of the Alps, such as the valley of the St. Gothard and Brenner or the Val d'Alzaska, seem less subject to rain; and, indeed, the climate was delightful and warm after Tibet. There were forests of Pinus excelsa and birch, and a profusion of wild flowers covered the ground-white anemones, potentillas, strawberries, wild gooseberries, and rhubarb, and a thousand gay flowering plants. Here was the home of many marmots and choughs. The valleys contained glaciers, with great moraine beds twisting down the sides, the black ice breaking off in masses. Above were the snow-white summits of many peaks.

The Bhotias of Kuti supplied yak drivers, one for each pair of yaks, and saddles made of wood, to which the loads and provisions for one month were securely attached by ropes made of yak's hair, very light and strong. Colonel Smyth had a tent of the smallest dimensions, lined with woollen stuff, just large enough for him to lie down, with a division in the centre making a second chamber at the other end for his servant, who was a very useful Kumaoni. Thus equipped, with the smallest amount of kit possible, they had crossed nearly every high pass in Kumaon, and done as much mountaineering as could be got in during years spent in visiting all the villages in a province as large as France, and instituting and inspecting schools everywhere. I had the pleasure of being present at several of his inspections here and in the Milam valley, where prizes were given to the best scholars. These Bhotia people are very intelligent and well-to-do, as all the trade in borax, salt, and flour, and goods of many kinds from India, passes through their hands. They are a fine, athletic mountain race very like the Gurkhas, not at all dark-skinned, and with features between the Aryan and the Tartar. Their women are 
much better looking than the Hunias, and dress more like the Hindus, but do their hair in a long flat plait hanging behind, in which rough turquoise stones are set.

August 6 found us on the top of the Kuti Pass about noon, after a climb of eight hours. This time the Hunias had not got word of our advance, and no one was there to stop us; in fact, during the whole trip we received great civility from the pastoral and trading parties which we met. The halt made for tiffin, and to collect the baggage animals and men who straggled behind, was welcome. The thermometer was boiled, and gave about I8,ooo feet. It was intensely cold, with cloud and snow driving. Snow lay deep on the north side, but we got peeps through the mist of the characteristic red and yellow coloured shingly plains below, reminding one that this was no longer Hindustan. The descent was over a great glacier which filled the valley beneath our feet. It was of clear ice, with lines of crevasses across, and streamlets flowing down in lines vertically, and long lines of white quartz rocks, which had fallen from precipices above and were gradually being borne downwards until they reached the lowest edge, where great blocks of ice were falling constantly into the valley below. These blocks carried with them the rocks and stones and mud, which fell in the same place, forming a huge pile of stuff.

Each glacier has usually its three lines of stones, two lateral and one central. The central line goes down into the roaring torrent which issues from a great ice cave into the gorge below. The lateral lines are deposited at each edge of the valley. As the glaciers of these parts seem to have receded like those of Europe, owing to changes of climate since the glacial period, it is natural that the débris, which has been tilted over for thousands of years in the same place on the ice, should leave great lines of 
stones buried in mud in the valley below. To those who have not studied geology and the works of Tyndall and Geikie, the moraine lines, which wind like great snails, and are found in many countries where glaciers have never been heard of, seem very inexplicable. Here the process was going on quite intelligibly. It was necessary to cross over a couple of miles of clear ice, the yaks going on ahead and avoiding bad crevasses. The clambering off the ice and on to the moraine, where a great gap existed from ice melting, was the ugliest part, but convenient snowdrifts still unmelted were chosen by the yaks, and at length our feet were on terra-firma. Terra it certainly was, but not firma, for the soft mud was treacherous for the poor beasts' feet, and the great stones and rocks formed an insecure footway; but at last we emerged on the flat shingly slopes of the valley below, and leaving behind the dazzling snow-drifts and slippery ice, and the dark caverns where the roar of waters and falling icebergs made the most hideous noise, the whole party rejoiced in the bright sunshine and warmth and easy going. The rocky bare summits of the watershed are the habitation of numerous graceful birds, familiar to those who have been on the cliffs of Cornwall and the west of Ireland, or Mount Pilatus in Switzerland-the Cornish chough, Graculus evemita. Their red bills and legs and glossy black plumage, and their wild cries as they circle round the rock pinnacles, are characteristic of all the passes, and remind one of very different scenes.

Soon we were welcomed by the neighing of numerous wild horses to the land of the kiang. Several herds kept circling round, the old stallions approaching in a quite threatening manner, snorting, squealing, and kicking up their heels, while the mares and foals galloped off at a more respectful distance. Some beautiful little gazelles 
(goa) bounded off like Italian greyhounds, and a flock of female Ovis Ammon was sighted on the adjoining hills, looking like red deer rather than sheep. A herd of burrhel had been startled while ascending the pass. The country next march northward was all bare rolling hills, with a few tufts only of broom and stones, where were great flocks of Kashmir white goats and tall sheep grazing round the black tents of the natives. Following the Duryumpti river, a source of the Sutlej, we came to a large encampment of traders at a plain called Gyanima ; and two marches brought us to a deep valley between walls of rocks, called Jaidam, with a clear, beautiful stream bubbling over pebbles, and plenty of grass for the beasts. This was reached after crossing a low range of hills. No sahib had ever been here before, but Smyth had heard of the ground as good for Ovis Ammon. There were innumerable white hares, all so tame they would not run away. The camp was a pleasant, sheltered one, and we determined to keep it standing and hunt all round from here.

The sunset across the plains of Tibet has a peculiar character, quite different from anywhere else. The colour is more crude, and the air seems, as it really is, quite thin. After the burning, scorching heat of the sun blazing down from straight overhead, there comes a very sudden chill, when the great red orb goes down with a run, and darkness comes on at once. There is no chance of lighting a big fire, as fuel is of the scarcest, and to keep warm one must put on all the clothes in one's wardrobe, and after dinner get to bed as soon as possible between big heavy blankets.

The ground was perfectly dry, and retained some warmth, but towards morning it froze pretty hard. We had seen numerous tracks of the great sheep, an animal 
as large as a donkey, whose slot is heavier than that of a r2-point stag. The hunting of a new species met with for the first time is an interesting novelty for the stalker, and the anticipation, when nearly about to be realized, becomes absorbing. The climate of this high elevation is of itself most exciting to the nerves, which seem often too much strained, when sleeplessness is the result, or very light and interrupted slumbers, which do not rest one. Drinking tea perpetually also tends to aggravate the complaint, and the greater rapidity of the heart's and lungs' action combines to produce an excessive tension resembling fever. The lot was drawn as to which side of our camp each was to hunt the day following; and we were glad to lie down on camp beds, which, if narrow, were comfortable and warm enough. Dreams of great rams' heads peering into the tent were so vivid that one had to jump out of bed and drive away the imaginary intruders. Scarcely had sleep come again to weigh down the heavy eyes when the howl of a prowling wolf round the tents and the fierce barking of the dogs would rouse one with a startling reminder to feel for the revolver under the pillow, and see that the rifles are tied to the tent-pole. Would day never come? Half a dozen times matches were struck to look at the hour, and as often a peep would be taken from the tent door to look for the dawn; but the stars still shone with provoking brilliance, and the nakuar log* slept heavily round the tents, and all seemed quiet and night unending.

At last it was the hour to begin the day's task: haziri was served, and a sleepy start was made while still the morning star shone brightly in the east, and a streak of light along the horizon was all that could be seen. My

* Servants. 
shikari, Kunkoo, led the way, with a strong Bhotia carrying second rifle, and a pony was led behind.

Truly the native superstition, that if the fairies or deities of the jungle are not propitiated the bullets will not hit, was well proved to be an irrefutable dogma. When daylight came we had crossed some hills, and from time to time searched all the slopes in view with the binoculars. Sure enough there was some movement among the gray limestone rocks opposite, which just caught the eye, and on bringing the glasses to bear I could see three tall, gray, deer-like animals grazing where some green grass grew. The colour of their smooth coats, almost white underneath, was so like the rocks that it was almost impossible to distinguish them. The dark heads and massive horns were slightly moving as they grazed.

Kunkoo, my new shikari from Milam, sank down flat and motioned me to do so, and we crept back behind the brow of the ridge. There was a light breeze, blowing down the valley which we had to cross lower down; and choosing our point of approach up a side ravine we hurried on, out of sight of the trio, making a considerable détour over rough shingly ground, till we completed an easy stalk, and at last got a peep at them from behind some rocks. The biggest was standing with head in the air, showing that he suspected danger.

The judging of distance when sighting an animal of unknown size and in a rarefied atmosphere is excessively difficult, and one is apt to make extraordinary mistakes. It was judged in this case to be 200 yards, but on pacing it afterwards it was found to be nearer 300 . The $\mathrm{r}_{50}$ yards sight was used, and the breast of the big ram aligned. A steady long pull on the trigger to avoid jerking. Hurrah! the bullet hit with a loud crack, and the ram fell on his 
head as if struck by lightning. The others went off with speed, and three shots at their sterns struck the ground wide and harmless. Kunkoo was wild with joy, and, while I loaded, ran up to the prostrate ram. This seemed easy work, and Smyth's stories of the difficulties of bringing Ovis Ammon to bag must be exaggerated. Alas for the uncertainties of the chase! This was but a momentary triumph. The big ram had been only stunned by being hit in the horn, and, recovering rapidly, he struggled to his legs before Kunkoo could reach him, and galloped off with his tail in the air as if nothing had happened to him, while I stood ramming down bullets and putting on caps, sick with rage and disappointment. He disappeared over the next rise on the track of the others, going strong, and none the worse for the bullet. We hastened on his tracks; and when we rose to the top of the ridge they were all three together on the third ridge, going like racehorses. The great tracks were in the soft gravel, and not a sign of blood. We followed for a mile or two, and then before us lay a wide flat or broad valley, and we sat down to scan the opposite slopes, quartering the ground with the glasses. The three tracks here had been multiplied by many, and we could see that a large flock had gone down the slope where we lay. Presently-oh, joy!-we caught sight of twelve fine rams quietly browsing about a mile off on the side of a ridge under a line of rocks; some were lying down, so they had not seen us or got any alarm.

By making a détour, they could be reached easily, and the line of rocks would form a shelter to stalk them. Getting on the pony, to avoid the unsteadiness caused by scrambling on foot over rough stones, the circuit of several miles was accomplished. The ridge was gained, and the wind being right from them, the moment of peeping over 
the rocks was one of fearful anxiety and extreme caution. Sure enough there lay below the rocks fifteen splendid rams, a few of them grazing, some asleep with their massive horns resting on the ground. There were several very old ones with enormous cartwheels of horns, very thin, and as if overburdened by the great weight. To choose the biggest was some difficulty. At last the crack of the rifle woke these startled giants from their peaceful repose. The bullet went high, clean over the ram's back, though the distance was under 200 yards and the sight taken was without any elevation. The stampede was immense. They looked as big as donkeys, and, except for their unmistakable horns, as little like sheep as possible. To miss such a mark was simply maddening. The second barrel, however, struck a good-sized ram in the shoulder, and he soon tailed off with a foreleg disabled and the bone evidently smashed. Then commenced a stern chase up a steep mountain. Every five minutes we saw the great beast some half-mile ahead of us slowly toiling onward with a foreleg swinging, and our hopes were raised that he must soon collapse; but he would again appear slinging along over easier ground, as he emerged from behind frequent ridges. Sometimes he was joined by another ram, which seemed to encourage him and run off again at right angles, so as to mislead us in tracking; but there was no difficulty as to the tracks, for blood flowed profusely and the stones were spotted with red, gory marks. The labour and exhaustion from running and scrambling up rocky hillsides was immense, and the anxiety of keeping him in sight made the chase a fearfully weary one. Panting violently for breath and perspiring, Kunkoo kept on bravely ahead and beckoned to me to run on. At last, after miles of this work and what seemed hours of toil, sloping along the steep side of the mountain, 
we saw the poor brute lie down near the top of a circling ridge. Kunkoo advised letting him lie for a while till he stiffened. This was a welcome opportunity to sit down and recover our wind, which we did, and satiated our thirst from a handy snow-bed, and our hunger by munching sattu, or parched grain.

Presently, as we scrambled up towards the ground where he lay, thinking he would not again rise, he sprang to his feet and disappeared over the top of the hill high amongst the clouds and snow, accompanied by the other ram. Two shots at 400 yards struck the sky, but not the rams.

It was now getting late in the day, and we were terribly tired; but on finding pools of blood where the ram had lain, we struggled on over the hilltop, which was not such bad going, expecting momentarily to come on the ram. The tracks were easily seen in snow and banks of wet mud and gravel, and the blood-spots were constant. At last he took a downward course, and we sighted him crossing a valley half a mile below us, walking slowly and limping badly. Our hopes were again revived, and Kunkoo's yellow eyes twinkled as he held up a stone well marked with blood, declaring that he would never go home till the sahib killed the big ram. Crossing the valley we pursued, though nearly worn out, and footsore with the sharp stones. We saw him enter a gully which cut the top of the next ridge; here it began to snow, and clouds concealed the view, but we went on the track, leading to a rocky precipice, from the top of which we could see valleys stretching away to the north where the clouds permitted. The ram was nowhere to be seen, and we wondered if he had fallen over.

Suddenly there was a noise of stones falling, and looking towards it I could just see the top of the ram's head over 
a big rock not ten yards away. He had his ears cocked as if listening, and was looking away. The rifle was soon bearing upon the back of his head, and the bullet this time did not strike the horn, but exactly in the centre between where the horns grew. He seemed to fall over the precipice, but was brought up by a big rock. There he lay stone dead, never again to lead his pursuers across the ridges and valleys of his native hills, a splendid specimen of primeval wildness. Here lay the great phantom sheep, the father of all mutton, the ancestor of all the varied breeds of domestic sheep which the world contains, tracked back after ages of domestication and changes wrought by climate and conditions of pasture to the original stock. As usual, domestication has vastly deteriorated him as regards size and power of defence against enemies. In comparative ease and safety, with fewer enemies to run from, the domestic sheep has thickened out from good pasture, and become shorter in the leg, while his hair has changed to wool.

The head of the nyang is unmistakably like the Scotch horny. The coat is all hair on the surface, but the wool is there in the form of pashm, a fluffy kind of underwool which seems constant in all Tibet animals, to protect them from the intense cold of winter. No sheep with the open wool and weaker physique of the domestic sorts could survive the hardships of this climate. That the Ovis Ammon is the common sheep, and not a distinct species, seems highly probable. The Rocky Mountain sheep, which $I$ have also seen in its native wilds and shot, is apparently the same species, varied only as to size.* The horns are mostly identical and the coat also. This fine specimen weighed fully as much as a red deer stag,

* Measurement of Ovis Ammon horns taken, the best of the bag: girth at base $17 \frac{1}{4}$ inches; length measured outside $42 \frac{1}{2}$ inches. 
and stood nearly as high. His feet were like those of a calf, and his track much bigger than a red deer's; the toes are less pointed and more upright. The horns were massive, and curled in a beautiful curve, almost circular.

The old rams get immensely heavy and thick horns, weighing over thirty pounds, and the natives say that they have often come across cases of the animal dying of starvation because his horns grew so large that they prevented him grazing, the mouth not reaching the ground. Indeed, we saw very old and weather-beaten heads lying on the ground which agreed with this description. The great sheep found further north in Central Asia, and known as the Ovis Poli, seems to be only a variety of the same species, the horns spreading outwards from the skull in a pattern similar to that of the common domestic sheep of Tibet, of which great flocks exist all over these plains. The varieties of curve in the horns of domestic sheep and cattle in different countries, which are without dispute the same species, are quite as marked and persistent as those of the Ovis Ammon and Poli.

Dr. Jerdon describes the nyang or Ovis Ammon as measuring 12 to $r_{3}$ hands high, and 6 feet in length, differing very little, except in size, from the Rocky Mountain sheep (to which I can agree, having shot both). The latter are only about Io hands, but have very massive horns. Other forms of sheep exist in Armenia, Kamschatka, and the plains of the Pamirs, which may all be the same species and the prototypes of domestic sheep, except that the latter has a long woolly tail, whereas the wild sheep has a short tail like a deer. The horns of the Ovis Ammon have been known to measure 24 inches in girth at base, and 45 inches round the curve. There is another wild sheep in the Punjab which has similar horns, but much smaller-the urial of the Salt range. 
This animal, living in a hot, dry climate, has very short hair and nowool or pashm, and its horns are much lighter. The domestic sheep of the plains of India is as small as the little Welsh mountain sheep, and has got a coarse kind of wool, more frequently black than white. During the dry season, when grass is almost all burnt up, it suffers from starvation and heat. It would be interesting to know if all these sheep will breed together or not. I . imagine they will interbreed.

To finish the record of this day's shikar, the most remarkable of a long experience, the great beast was left partly covered up with stones and broom bushes, which grew on the face of the khud. It began to snow and sleet in an unpleasant manner, and we were in doubt which way to go to get to camp; but Kunkoo was not long in fault, and we hurried on, following down a valley which presently opened out in the right direction. We had been out since 5 a.m. and were pretty tired and hungry, and evening was fast closing. The pony had been left with his syce early in the day, and we had a long distance to tramp. Luckily the snow ceased and clouds began to clear, and as we rounded a bend in the valley, by the edge of the stream there stood, not roo yards away, six splendid old rams, quietly drinking. They just lifted their great heads and stared at the unexpected apparition. Their large black eyes and gracefully curved horns were most striking, and they did not seem at all alarmed. Steadying the rifle which I was carrying, I took a most deliberate aim, and, oh horror! the rifle missed fire, the second barrel likewise. They went off behind some rocks. Beckoning to Kunkoo, who was coming after me, to hand me the other rifle, I rushed round the rocks, and was overjoyed to see that they were standing not 200 yards off, again staring in my direction. Choosing the biggest head, I 
felt now sure of a trophy, but, alas! the sleet had penetrated the nipples of this rifle also, and the caps were wet; the first barrel was a miss-fire and the second a hang-fire, so the astonished nyang scampered off unharmed, and swearing was not the word for the expressions which followed. Such is the uncertainty of big game shooting. The disadvantages of the old nipple and copper cap muzzle-loading rifles were indeed most serious, and bara shikar in India was very much handicapped before breech-loaders were invented. Yet for how many years sportsmen went on believing fondly that the percussion cap was the most perfect arrangement that modern science could invent, and that breech-loaders could never supersede it! Little did we think that not one, but fifty different patterns of breech-loaders would have come into use, and magazine rifles, so perfect and practical that it is hard to know which is the best. Big game had some chance of escaping in days gone by, but now in a few years big game will be no more.

The night came on rapidly, and sleet turned to snow. It was ten o'clock before the camp was reached. We were thoroughly tired out and hungry and cold. However, Smyth, who had not had a shot, congratulated us on having secured a good head; and a good fire made of yak's dung before the tent door warmed everything up, and hot soup, followed by stewed hare and a roast snow pheasant and a small glass of grog, kept for occasions only, did wonders in restoring the inner man. Smyth, who considered Ovis Ammon to be the most difficult game to find and shoot of all that exist, was surprised at the number of rams I had come across. He declared that to get ten shots in one day at good heads was a piece of fortune he had never experienced. He expected that they would now leave this locality, having been disturbed, 
and his expectation proved correct; for during the next three days we hunted miles of fine country in vain, and saw plenty of tracks, but no nyang. We had several shots at the beautiful little gazelle called goa.*

It is astonishing how full these great plains and rolling hills are of animal life, principally birds, which are quite tame. They nest in numbers on the ground, and the air is full of larks singing aloft, besides numerous small migratory birds, which sit and look at one at five yards off. There is also a remarkable bird, the snow pheasant or snow cock (Tetraogallus Tibetanus). When tramping over the bare ground, one sees troops of them running amongst the stones and rocks, stooping low and almost invisible from their gray colour when they squat. They seldom take wing except when flushed by a dog, and then the whole covey runs and rises and shoots along about two feet above the bare ground. They are heavy, fat birds about the size of a bernicle goose, and have powerful bills and feet like turkeys. They are easy to shoot with a rifle, and are excellent eating, being layered with goose-like fat.

There are also snow partridges (Lerwa nivicola) resembling a ptarmigan, which sit close and are almost invisible on the bare ground in coveys.

* The goa is described by Jerdon as a distinct species, the Procapra picticaudata of Hodgson. 


\section{CHAPTER XIII}

NO MAN'S LAND: RAVINES, DEEP VALLEYS, AND HIGH

\section{PASSES}

Ir was now getting near the time when the rains slacken in the plains of India, and the sun begins to go southward. It is no longer vertical, and we have a sensible diminution of temperature and colder nights. There is a route over the range crossing to the Bhotia country at Milam by the Milam ghat. The country to the north of this pass is so cut up by ravines and deep defiles, formed on one side by the head waters of the Sutlej, and on the other by the affluents of the Ganges flowing southward right through the range, that there are three passes to crossthe Balch Dhura, Kyungar Dhura, and Unta Dhurawith deep defiles between, before reaching Milam. Such a confusion of valleys and mountains exists that it is hard to understand the geography. These valleys are a sort of no man's land, and if snow falls travellers are liable to be trapped in them from drifts stopping up the ghats. The geology of this country is most remarkable, and the formation of the rocks, from their being so mixed up and contorted and turned upside down, has been described by Sir R. Strachey, R.E., who surveyed the country, as chaos.

Having hunted a considerable area of open plains for Ovis Ammon during two weeks, during which we had 
varying success, but never a day like the first one described, and having got some good heads and also brought to bag several good burrhel, which were excellent for mutton, we turned again for the passes towards Milam. During this march, which was all over country of the same barren character-wide valleys and ridges, all of rocky shingle, with grass growing only in the lower valleys-we scarcely met any natives, nor any traders, as they keep to the regular routes, and only one encampment of Hunias of the shepherd class, with flocks of sheep and shawl goats. These beautiful animals, of which I purchased a couple, have long silky white hair of the finest quality falling from their backs. The pashm is used for making the soft Rampur chaddars.

These people were very civil, and supplied us with butter and milk. Our Bhotia guides steered more by direction than by knowledge of the paths, of which there were none very marked, only sheep tracks leading in every direction. The natives accounted for game being scarce by supposing that a pack of wild dogs had lately been hunting the country. This is a common story told by shikaris in India, but except on one occasion, in the Central Provinces, I have never, in ten years spent mostly in jungles, come across them. Whether the wild dogs, which certainly occur in the Himalayan forests, come across into Tibet to hunt the Ovis Ammon is a question difficult to determine, but it is quite possible.

On one of our marches we were told that it would be hard to find water. A Hunia from a shepherd camp, who gave us some fresh milk, was good enough to volunteer to show us where there was water, and rode on ahead on his rough pony. We followed him for hours up a winding valley till night came on, hoping to be soon able to come to camp; but where he expected to find water 
the spring was dry. The ponies and yaks carrying our loads were very weary and thirsty, the yaks grunting frequently to one another. We had all to lump it, and pitch our tents and go thirsty to bed. Luckily we had the kettle full of milk, and made chocolate; but, between the thickness of the mixture and the richness of the milk, it was a sickening beverage, and we felt thirstier after drinking it, and suffered indigestion as well as thirst. At first daylight the yak drivers had collected and loaded the poor, thirsty beasts, and we started, still following the ravine, and over the top of a high plateau and down to the north-west in the direction of our route. Panting under a hot sun, we pushed on, riding our stout ponies; at last, down in a hollow where paths converged, we came on a green pool of stagnant water. There were tracks of yaks and sheep having been here recently standing in the muddy pond. Our poor ponies rushed in and thoroughly enjoyed themselves, gulping down the turbid liquid, though it resembled pea-soup. We waved to our following to come on, as we could see the melancholy procession of yaks and men just topping the hills we had crossed. On they came with improving speed, as if scenting the water, and soon all had their noses well immersed. Having filled a vessel from the least disturbed place, and filtered the contents through pocket-handkerchiefs into a degchi, our servants were not long in boiling the stuff; and when made into tea it was the most delicious drink imaginable.

The vertical sun was hot; the bare arid ground, covered with hot stones, reflected its dazzling brilliance, and the heat was as trying as in the plains of India, and the direct rays much stronger, owing to the perfectly clear atmosphere. We, as usual, boiled the thermometer, and found it over 16,000 feet. The water boiled at $180^{\circ}$ temperature. The direct rays of the sun raised the thermometer when 
protected from the wind to over $160^{\circ}$ Fahrenheit; so that at an elevation a little higher the sun was actually hot enough to boll the kettle. When we came to exposed places, or when night came on, the cold wind was most cutting after the heat of the mid-day sum, and our faces were burned and blistered beyond recognition. Our noses suffered most, and became cracked across the bridge in several places, open, bleeding gaps down to the bone. The eyes were also affected from the glare, and if our noses had been seared with red-hot irons they could not look or feel worse. It took many months for these scars to heal. The Bhotias gave us some excellent ointment called fulteel, made from a tree in Nepal. It was like spermaceti ointment and had a pleasant smell. With this we covered our faces daily, and made nose caps of fur to keep off the cold wind, which it was agony to face without some protection. We looked as greasy as the rest of the inhabitants. Washing operations were not a luxury, the water being generally about freezing-point in the mornings; but we usually postponed them till breakfast, or rather tiffin-time, when the sun was strong. Life in this grand, bracing air is thoroughly exhilarating; one feels always hungry, and muscle and condition become of the hardest. But there are drawbacks to one's comfort; and being on the tramp day after day from 6 a.m. often till ro p.m. is trying and desperately hard work, especially as sleep is disturbed at night from the high elevation. No wonder that the natives are a lazy-looking lot, and never walk a yard if they can ride. The rare atmosphere, luckily, does not affect the ponies, which seem in capital wind, and clamber up the steep hills without showing distress. Some of the ponies will not stand too protracted marching, and go lame from the toes wearing away and the blood coming, but after a few days' rest the horn 
grows again without ill effect. We saw only rarely a pony with shoes, though they seemed to get very little idle time. Gunt ponies will go in India without shoes, except in the rains, when the horn gets too soft.

One usually camps in a valley where there is some grass, and the ponies and yaks know how to find out the good places, and will stray away if the camp is not well chosen. But the yak drivers are careful to find a good place, as the straying involves a tiresome search, and watch their charges well at night, tethering one or two if necessary. We only lost our animals once in the night, and they had not strayed far. We hunted a country known as the Lal pahar, the 'red hills,' from the colour of the soil, which is Indian red, approaching to deep crimson in places and vermilion in others, where we had several stalks after Ovis Ammon and burrhel, with no great success, as the ground was too open to get near enough to such wary beasts. Wo came, after several camps, into a most peculiar country. The soil here was composed of alluvial sand and gravel, and there appeared in front of us an almost level plateau; but to get across it entailed climbing down into an endless succession of deep nullahs, all trending towards the Sutlej, which ran to the north-east, while our course was south-west, and either clambering up again, only to perform the same operation incessantly, or following the nullahs, which led down in the wrong direction. Their depth was only a few yards at the higher levels, where thousands of veinlike affluent trickles had cut into the soil, converging to one another and joining two or three into one deeper ravine, which went on winding and getting ever deeper as the side-streams joined in, until the depth of each nullah would be Ioo, increasing to 500 feet, with sides so steep it was hard to climb up them. Not that there 
was any water in these ravines; for until one got to a main artery in a particularly central nullah there would be not a sign of a stream. There are many places in India near the Ganges and Jumna where such ravine-ground exists; but there in the rains every nullah has its little torrent, and the process of cutting into the soft soil is going on under one's eyes. In Tibet there is no rain to speak of, and snow falls in winter not too heavily. When these deep ravines were cut out, and how many thousand years it took, is a mystery. The cutting was done, certainly, by water and not by ice, its action being perfectly distinct. Here there are no marks of recent glaciation.

We started from our camp at about 6 a.m., giving our yak men orders to take the baggage and tents to a particular camping ground, which they said they all knew well, where was a good stream of water-a march of about fifteen miles. Smyth and I separated with our shikaris to hunt the ground, hoping to find nyang or burrhel, each taking a different direction and agreeing to make a circuit, finishing at our camp. Kunkoo, and a man to lead my pony and carry lunch and second rifle, came with me. We tramped all day for miles, seeing several herds, and shooting one burrhel and missing several others.* Ascending ridges and going down into wide open valleys and crossing the dry beds of rivers, towards evening we came into the true ravine country, and our labours com-

* I ascertained afterwards that the barrels of my rifle, from being seldom emptied at night or cleaned, were leaded. This and the difficulty of judging distances lost me several fine heads. The difficulty with muzzle-loading rifles was not being able to discharge the barrels for fear of disturbing game near our camps. When barrels become leaded and foul they shoot most inaccurately. The high elevation and dry climate of Tibet also have the effect of making the bullet shoot high, which must be taken into account. I learnt these lessons by sad experience. 
menced. We crossed hundreds of nullahs, all exactly alike and leading in the wrong direction. They got deeper and steeper, and we were tired out. Kunkoo decided that we must follow down a principal ravine, which seemed to have a sort of a path along its dry bed. It became dark, and we tramped on and on; many side nullahs of equal size and importance kept joining into our nullah and making it deeper and bigger, but there was not a sign of water or of camp. Luckily a lovely full moon rose majestically into the deep blue-black sky. The silence was oppressive, except for the clank of the ponies' feet, which echoed against the walls and buttresses which hemmed us in-huge high walls, steep and all sloping at an equal angle. The shadows were quite black and the moonlight dazzling white. The thinness of the atmosphere probably caused the shadows to appear darker and their edges more sharply defined. The effect was quite weird, and comparable to what might be experienced on the moon. Kunkoo was fairly puzzled, and was several times inclined to turn back and try up some of the converging nullahs; but what chance was there of hitting on the right one among hundreds all exactly alike ? We fired off guns at intervals to attract attention, and the sound, exaggerated by the stillness, echoed like whole batteries of artillery, reverberating from bank to bank with thunder oft repeated, and dying away in unknown recesses. Still we went on, on, tired out, hungry, and not knowing which way to turn. Occasionally faint sounds as of voices seemed to vibrate in the air, but we could not decide if they were real or imaginary. Still they seemed to be repeated, and our hopes revived, to be again blasted by the mocking silence.

At last there seemed to be strains of music somewhere, but whether above or below or in what direction it was 
impossible to tell. We shouted in reply, and soon heard voices of men talking; the words were almost distinguishable, but, strange to say, the sound came sometimes from one side and sometimes from the other, like the voice of a ventriloquist, and the echoes, repeating the sound, gave a musical effect like the notes of an organ. The voices came nearer and nearer, and at last our men appeared with torches, coming down a side ravine, where we least expected, in search of us, and we got to camp about ro p.m. Dinner ready and a good fire made up for everything. Smyth, however, had not turned up. I fired shots and sent the men out again in different directions, and they found him some miles down the stream, which only broke out of the ground in small trickles here and there. He had got two burrhel, but had given up all hopes of finding camp, and had gone to sleep in a sheltered nook. His shikari had heard the shots and answered. The walls of the ravines were here 300 or 400 feet high. Their width was only about 300 yards at the top and 50 at the bottom, which was flat and easily traversed. A more extraordinary and puzzling country I have never come across. There was a sharp frost at night, but the sides of the ravines retained so much of the sun's heat that it did not get really cold till near morning.

Next day we had much climbing to find our way out of the ravines; but the Bhotias recovered the lost route, which led southward and upwards into the heart of the snowy range which lay across our path.

There are two routes from here and three ranges to cross. One route of three days, at very trying elevations; the other way is a longer route, but the passes can be done in separate marches. This was the route we selected, and we marched for the Balch Dhura ghat, a high pass, I7,6oo feet, which we ascended, and 
came down into a deep valley called Laptel. Here we halted and hunted the neighbourhood. There was plenty of luxuriant grass for our beasts, and we hoped to find Ovis Ammon, as the ground was covered with their tracks and the valley is not occupied by either Bhotias or Hunias ; for the danger of being snowed up in it is great, when flocks and herds would all perish. We saw no ram Ovis Ammon, but large herds of females. We shot one fine old ewe with a lamb, and tried very hard to catch the lamb, which would not leave the place. Smyth was anxious to procure a live specimen to send to the Zoological Society along with the yaks which he was sending, but for want of a net we found it impossible. The head of the female (which I have got) is a fine one, with graceful thin horns curving backwards.

The bottom of the valley where we camped is only I4,000 feet, and the climate is far less rainy than on the Himalayan side. Vegetables would grow here, and we saw wild leeks and vetches and rhubarb, and had a rhubarb pie, the first vegetable stuff we had eaten for a month.

Were it not that Laptel is a regular trap, this valley is a fine grazing ground for sheep and cattle. There was a herd here of kiang, which careered about our camp in a most objectionable way, making the most fearful disturbances. We witnessed a battle royal between two stallions, which for ferocity and wicked fury surpassed any fight I have seen. Again and again the pair went at one another like tigers, biting and kicking and mauling, the blood flowing freely, while the fearful yells and roars they kept up were terrifying to hear. This went on for hours. Sometimes they would wrestle, locked together like prize-fighters; sometimes they would chase one another all round the valley, bounding across chasms 
and rocks at a frantic gallop. On one occasion the pursued, who wanted a little rest, took to the steepest rocky precipices and distanced his pursuer, following the sheep paths on the face of the hill. The enemy kept pressing after him till eventually he could not go forward or turn backward to meet his pursuer. I watched him with the glasses, and saw the brute deliberately jump from the point of a jutting rock and go down into the abyss below. The precipice looked to be a sheer drop with rocks below, where was a stream hid from view. Into this he disappeared, and the other stood looking down, but failed to follow. Not an hour afterwards they were at it again in another place, screeching and hammering one another with renewed fury. I shot one of these brutes to preserve the peace, and his skull now hangs on my walls among the other trophies. The one I chose to make an example of was the bigger bully who funked the precipice. The lesser one had shown such pluck in coming to the scratch so often, and making the most appalling jump any horse ever made and survived, that he deserved to be forgiven for his otherwise disorderly behaviour. Henceforth he no doubt became lord of that valley, and was treated with proper respect both by the younger stallions and the mares of the herd.

The horrible roars and shrieking made by the wild horse when fighting sound something like a noise between a donkey's bray and the squealing of a jackal, but far more ear-piercing and discordant. The kiang is found in considerable numbers. $\mathrm{He}$ is, according to the Hunia accounts, untamable. There was a young one purchased at Bagesar fair from some Hunias for a small price. The purchaser thought he had a good bargain, and proposed to send the animal to England; but when his men went to bring away the purchase no power would induce 
it to leave its foster-mother, an old Tibet pony, which the clever Hunias refused to sell except for an exorbitant sum.

At Laptel we said good-bye to the kiang and the nyang and other wild inhabitants of Tibet, and had a long and trying march to Topidunga in the deep valley of the Kyungar river. The geology of these parts is most remarkable. The great chasm through which the water from Tibet flows cuts down the great central body of the range right from top to bottom. The very bowels of the earth are laid bare to the eye, and one sees the strata of rocks, which were deposited in the bottom of the sea like beds of sand or mud or calcareous deposits of seashells, stuck up on end instead of lying flat as the sea left them. Some of them are composed entirely of sea-shells, conspicuous among which are the ammonites, which we observed in heaps lying on the surface, being solid limestone casts of delicate nautilus-like shells, which in life were the abode of primeval molluscs. They were of all sizes up to great cart-wheels of 4 feet across, convoluted in beautiful proportion like a flattened out snail-shell or the horns of the Ovis Ammon, which derives its name from the cornu Ammonis of ancient mythology. There were visible from the summit of this pass, on the face of the cliff, a variety of rock formations of various colours, ranged like books in a shelf. Such sections of the crust of the earth, by which its layers and beds are cut into and exposed to view, are common enough in all mountain ranges; but for grandeur nothing I have seen elsewhere can compare with these gaps cut down into the heart of the earth right through the Himalayan range. It must be remembered that, while the top of the pass is about I8,ooo feet, the stream emerges from its desperate passage through the gap at a place on the Dhauli river not 
fifteen miles away at Malari-only Io,29o feet on the map.

From this pass one gets glimpses of the great Trisul group. Some of the summits were so steep that no snow could lie on the northern side, but the rock cliffs appeared white even against the snow, as if of pure white marble; while others were of black basalt, towering like huge black giants against the white world of perpetual snow. The descent to a place called Topidunga, in a deep valley, was the most appalling attempt, apparently down an overhanging precipice. Our guides informed us there was no other route, and down we must go. Feeling desperate, we craned our necks over the edge, seeing the track disappear below us and plunge over the edge into space. However, we descended one by one, the ponies and yaks following behind. This was a most dangerous proceeding, as every stone detached would bound down the precipice, accumulating force as it sped. We had to let the beasts remain until we were past the most perpendicular descent, when they followed as best they could. It was a breakneck march, and how the poor beasts got down safely without rolling head over heels to the bottom is a marvel which is quite unintelligible, as the rock was loose shingle and rotten, and the stones to which one had to cling were themselves only sticking to their places by a miracle, and were balanced so lightly that a kick would overthrow them, to set others falling and start a general landslip. However, we got down the three hours' descent safely till we came to a narrow gorge between lofty precipices, with a roaring torrent many hundred feet below, which could be heard but not seen. Luckily there was a mass of snow jammed between the rocks, which formed a bridge or viaduct, on the top of which we traversed, the path emerging, after many turns, in the 
valley below, where was some space among the rocks to camp on, and some roots of bushes for firewood. The poor ponies sank in the snow and had to be helped to get across. The men certainly showed great mountaineering qualities, and worked splendidly with ropes, and by carrying the loads they got everything down to camp.

The change from the almost rainless climate of Tibet to a damp atmosphere, with clouds and dropping rain, showed that we were now south of the main range; and our camp was both cold and uncomfortable. We had still, however, a third high ghat, said to be over I8,000 feet, to surmount before leaving this ' no man's land,' and descending into the British pargana of Juhar and the Bhotia town of Milam. The path is called the Unta Dhura, and is not the same as the Milam ghat, which is the more frequented trade route. We met a large party of Hunia traders with about 2,000 sheep and goats lower down, who had come across by the other pass. They had been nearly thirty hours doing the passage, as they are afraid to camp on the trip for fear of being snowed up. Many pack-sheep and travellers have been lost on this pass, and the carcases of the poor dead sheep are seen in melting snow-drifts with the flesh still on the bones. The sheep were fine strong ones, with the long straightout horns, mostly shaped like the Ovis Poli. They carry packs of salt and borax weighing twenty to twenty-four pounds each. They looked very weary and footsore. The men had big sheepskin coats, and were prepared for bad weather. They cannot count more than a score, and do not know how many sheep they possess; but they know if they miss any.

We were now so inured to high elevations that we did not feel any ill effects during the passage of these ghats, not even the usual headache; and we tramped mostly on 
foot, the ground being too steep to ride on ponies. In descending the Unta Dhura to Milam the path follows down the surface of a very extensive glacier. We found the going very slippery, but not too steep. Its surface was cut up into vertical furrows by a number of streams, which were caused by the warm wind of the south-west monsoon coming up from the fervid plains of India, still blowing as hard as ever. The great mass of ice, half a mile in width and many hundred feet thick, looked black and clear under our feet, always creeping downwards and forcing its way between great granite precipices which hemmed it in, and then bulging out into a wider sea of ice like a slow-flowing river. The walls of rock were polished bright, and scored with lines engraved in the solid granite during the course of ages.

Next morning we got to Milam for breakfast, and found the villagers had pitched some tents ready for us, and now offered us a welcome and every comfort. Milam is one of the largest of the Bhotia villages, being the capital of Juhar, and has a considerable area of cultivation, as the valley is wide. But its source of wealth is from trade between Tibet and India, and the people possess great flocks of goats, jhobus, and ponies. The elevation is I, 682 feet, and oats and barley grow well. The village looks like a walled town; it is built of stone, and the backs of the houses, being all turned outwards, form a high wall with no windows. The people sit on balconies and flats facing inwards, engaged in their household work, and look happy and comfortable. Their dress is superior to the usual run of Bhotias; the principal men look quite like gentlemen, and wear white, finely-woven serge garments; they are very clean and their manners are excellent. The women are often good-looking, and their long black hair is tastily plaited. The children are 
bright, intelligent, and clean, and attend school very diligently.

Smyth inspected the schools and was well pleased. We also interviewed some pundits who were preparing to start for survey work in Tibet under Government authority. Smyth had selected these young men, and sent them to the Engineering College at Roorkee to be trained by the instructions of Colonel Montgomerie, R.E. They were waiting for one of their chronometers, which had gone wrong and had been sent to Roorkee to be regulated. They started shortly after on their eventful journey, and one only succeeded in getting to Lhasa, which city he surveyed surreptitiously; and had many adventures during several years' travelling, as duly recorded by the Geographical Society.

There are many villages further down the valley, which is extensive. The celebrated Milam glacier is situated up the main valley above Milam. A great river issues from its base, coming out from under a cavern in the ice, which is some 400 feet thick. This cavern is vast and fearful to look at. The glacier breaks off as it melts in great blocks, which fall at intervals on to the flat 400 feet below. The crash of these falling icebergs is appalling when heard at night. The long space of flat open valley below the cavern shows that the glacier has been receding. If it were to advance it would sweep away Milam and all its inhabitants. One cannot go too near the cavern.

The Milam glacier derives its source from the great icefields which fill up the entire valley lying between the snowy peaks of Nanda Devi, Trisul, and Dunagiri. These summits tower up to the skies to the west and south. At this season they are concealed by the vapour, but occasionally there was a break in the clouds, when these giants could be seen. There were on the glacier surface lakes 
of clear water over ten acres in area, with islands in them. There were rivers flowing into the lakes. The surface was a plain, and widened out at the head to several miles. When clouds concealed the heights it was like travelling on an icy sea. As far as the eye could reach on all sides, the flat surface of the ice. This mass is always travelling forward. There are no cracks or crevasses to be encountered for miles as we advance further across this veritable mer de glace; but it begins to rise as one gets nearer to the source, and the surface to become rougher. The usual curious features of moraine lines, and of rocks supported like tables on pillars of unmelted ice, were very marked; and there could be no better place for experimenting on the movements of ice and observing its extraordinary behaviour.* That the centre of the glacier and the top, as in a river, flow faster than the sides and bottom, has frequently been observed. In one solid block it will conform itself to the winding course of the valley it fills up. This is very marked in the Milam glacier, which makes a great curve to the south as seen from above, after coming for miles in a north-easterly direction. It is joined also by other glaciers from the various peaks, which unite into one great ice-lake.

The great writer Lyall, who thought out many problems, comes, I think, to the conclusion that the elevation of a great mass of mountain like the Himalayan range, composed of strata which, though now found miles above the sea, were once formed perhaps as deep below its surface, was a gradual and quiet process, and that such movements of elevation or depression are going on under our feet steadily, though unperceived. It is, however,

* Sir Richard Strachey, R.E., in 1848 measured the movement of the Milam glacier, which he describes as ten miles long, 4,000 feet across, and as moving downwards at the rate, near its centre, of 44 feet in thirty-two days. 
hard to believe that the setting on end and crumpling up of the solid rock, which one sees, as it were, shot up and banged about and fractured and twisted in every conceivable mode, could have happened always in a quiet, leisurely way, and without some fearful convulsions, compared to which our modern earthquakes are mere faint vibrations.

This Tibetan region, with its high plateau, the roof of Asia, and its great rivers and deep valleys, all centring in one highest point; its old-world inhabitants and its forbidden thresholds, has a fascination peculiar to itself. There is a strange fatality against the thorough exploration of the sacred city, where reigns in unbroken seclusion the Dalai Lama, the boy incarnate Buddha; and even the most determined explorers have failed to get to Lhasa.

The regions to the north and the great central lakes, which have no outlet to the sea and are being absorbed gradually by the sand of the great desert of Gobi, have been explored recently by Dr. Sven Hedin, Captain Wellby, and others, but they have all failed to get to Lhasa. The most recent explorers (I899), Mr. and Mrs. Rijnhart, from Kuku Nor, were stopped at the river Tachu; and a sad tragedy has been enacted, the lady returning alone, uncertain as to her husband's fate. Yet in I774 an Englishman-Mr. Bogle-sent by Warren Hastings, was received by the Teshu Lama at Shigatze in the most friendly manner, and established a prosperous commercial intercourse with India. In I8II Mr. Manning visited the Dalai Lama at Lhasa, and found him a most peaceable and holy youth, and well disposed towards the British.*

The natives of Tibet are quiet, good sort of fellows;

* The account of Dr. Sven Hedin's most recent approach to Lhasa has still to be given to the world. 
but their Government, since the two invasions by the Sikhs and Nepalis, has had a fixed prejudice against any travellers getting too far into their country, fearing that they may be invaded and annexed; but their principal fear is that their sacred places may be desecrated. The attempt lately made by Mr. H. Savage Landor to force his way to Lhasa, accompanied by two Kumaon coolies who did not understand the Hunia language, after quarrelling with his Bhotia couriers, and having no yaks or even ponies to carry him or his baggage, was bound to end in a fiasco.

Certainly, when we had once come to agreement with the Zung-pun, we found the Tibet people most polite and peaceable. It is true that Mr. Robert Drummond's visit in 1860 to the Manasarowar lake, and putting a boat on it, had given great offence. The Lamas have great power, and dread that their most sacred temples may be desecrated by heathen dogs of Englishmen, who go everywhere; and they naturally raise every obstacle to their entering from the British frontier.

The success of Mr. Bogle was the result of the policy of Warren Hastings of encouraging trade with India; since then our Government has discouraged all intercourse with the Tibetans; and fairs, where trading used to be carried on, have ceased to take place.

The Bhotias who live in British territory and under British laws are aware that the British do not intend to interfere with their trading rights. They are excellent subjects of the Empire, and all the trade between the two countries is in their hands. With us they felt perfectly safe, and proved themselves faithful and plucky assistants, and were our friends; but they expected to be treated rather as allies than as servants, as all men beyond the British frontier are equal.

Our carriers, not being themselves armed, seemed to 
have great satisfaction in the number of our guns and rifles, and the superiority of their shooting over the old matchlocks of the natives; and our shikaris felt extra brave when carrying our second rifles, and all behaved splendidly. The present of some gunpowder and lead made them supremely happy, and it was au revoir at parting rather than good-bye.

Among the Bhotias the custom of polyandry, which some book-writers have described, does not obtrude itself at all on the observation of travellers. In fact, the families of the Bhotias seem to have a fair proportion of women to men, and have husbands and marriage customs like any other people, and the little girls playing about the houses seem to be just as numerous as the boys. They are not at all shy, and are very bright and intelligent, and apparently nearly as well taught in the Government schools as European children. The women are very hardworking in household duties and in making their often highly ornamented costumes. Both men and women are always busy spinning woollen yarn, and the cloth they weave is excellent and durable. The account given by Mr. Savage Landor of these people, whom he names 'Shokas,' does not at all agree with my observations. 


\section{CHAPTER XIV}

SUBALPINE REGIONS: HEAT, RAIN, AND DRIPPING JUNGLES

HAving parted with our Bhotia shikaris and faithful yak-drivers, who were excellent intelligent fellows and wonderful mountaineers, the time had come for recommencing the survey work. My pleasant companion also had schools to inspect in the Dharma valley. Therefore, with mutual regrets, we had to part, each on his separate route. My path lay down, down perpetually into the steamy hot and reeking climate of the lower hills, still immersed in cloud and rain, the final burst of the monsoon.

I commenced my march south-westward to the Pindar valley, where the Commissioners' instructions to report on and survey the extensive area of forests there existing must be carried out.

To reach the Pindar it was necessary, for a few marches, to " descend the defile of the Gori river, blocked up by vast beds of snow, and quite impassable lower down, and to cross westward by the Gula Dhura over a series of ranges which spring from the great mountain mass of Nanda Devi and its fellow peaks, crossing also the valleys of the Ram Ganga and Sarju rivers where they first issue from the snow. This was an arduous and trying march. I was, however, joined by the native surveying staff, who had not come into Tibet; and where native officials march the arrangements generally go smoothly, as they 
take good care of their own comfort, and the villagers are more ready to provide coolies and supplies. Very few British had ever been in the villages lying in these unfrequented valleys.

It rained all day and all night, the tent getting so wet and heavy that it was hard to carry, and, except occasionally, was not pitched at all. We either slept in caves or in native sheds made of bamboo chappars, not too clean, where insects of all sorts were abundant, from fleas to scorpions and centipedes. Mosquitoes were as large and voracious as hawks, and moras kept biting day and night. Then there are snakes abundant of all sorts, and leeches swarm on every stone, and stick to the feet and ankles of passers-by. The poor goats and cattle are infested by them, and run down blood. They get into dogs' noses and stay there, and cannot be got out. For twenty days our clothes were never dry, or if we did get a chance to dry them in some gleams of sun, they were wet again in an hour or two. We gave up trying to keep dry, and slept in wet things unconcernedly. The sheepskin coat made a useful night coat when one slept in caves, as it kept out most things and was better than damp bedding.

The heat was intense in the valleys, and the air heavy and muggy. We regretted the climate and cool air of Tibet. We had often long distances to march over high passes where it was cooler, but most of the paths were mere goat tracks through dripping wet underwood and tall spear-grass. Spear-grass is specially constructed to annoy. Every stalk is stiff and pointed, and runs straight in through woollen clothes, penetrating to the skin. The points are as sharp as needles, and are provided at the end with detachable barbed heads, which stick an eighth of an inch into the flesh and cannot be taken out, and cause great pain and irritation, and produce festering. 
Sheep suffer terribly from spear-grass; and for that reason the natives here keep mostly goats, which do not suffer so much, their coats being finer and more open. It is quite common to find in mutton whole joints of speargrass which have gone right through the animal's flesh. I wore long leather boots above the knee, or else extra thick puttees. They would keep out spear-grass for a time, but not altogether, and half one's time in camp was occupied in taking spear-grass out of one's clothes. The flies, however, were the worst pest of all. They were in millions, buzzing in a distracting manner and settling on one's face, and where they settled for a moment they began to bite. From morning till night it was one perpetual fight to keep the flies out of one's eyes, nose, and mouth, and out of one's tea or eatables ; and when, after a very tiring march, one felt inclined to sleep a bit longer in the morning, they took good care to begin buzzing in the most maddening manner from 5 a.m. all about one's head, and settling on one's poor body wherever uncovered. We often marched late, as there was no object in starting very early, the sun being always behind clouds and rain coming down in dreary downpour.

The sound of dropping water was everywhere, and every hollow contained a rushing, roaring torrent. Landslips were not infrequent, and the paths were slippery and muddy, and the fords very dangerous. Then the thunder and lightning were appalling ; scarcely a day passed without a thunderstorm, and sometimes it thundered and poured steadily for the whole twenty-four hours. We saw little of the scenery, as the mists and clouds filled the valleys, and we tramped all day along paths which followed the ridges, the luxuriant growth of weeds and ferns and bushes being higher than our heads. We had guides from village to village who knew the route. 
There was, however, a distinctly marked path where the sheep and goat caravans sometimes came in the cold weather, and the caves were blackened with the smoke of their camp fires. There was a kind of balsamBalsamia impatiens - which grew about these camps and level places where the sheep halted. It was 7 or 8 feet high and concealed everything, and the path was quite grown over. The seeds appear like goodsized grain. When the pods are touched they fly open (hence the name impatiens). The natives eat the seeds sometimes, and they have an intoxicating effect. These patches are a favourite haunt of bears, and they also become shockingly intoxicated, and lose their accustomed caution, which usually makes them conceal themselves on the approach of men. In groping one's way through these fields of high balsam it was necessary to go with observation. On one occasion the khansamah Sirdar Khan, a plains Mussulman, who had an instinctive dread of all wild animals and of everything in the hills, was mooning along through the balsam, having got on a wrong track, he himself being a bit under the influence of bhang (wild hemp) smoked in excess. Suddenly he found himself nearly in the arms of a huge black bear. Bruin, however, was quite half seas over and too far gone to hurt anything, and the khansamah escaped only scared.

In one day's march I had six shots at bears and bagged four. The others rolled themselves into the long herbage, and disappeared head over heels down the khud and were lost. The skins of these bears were not much good, as they were changing their coats and very ragged.* There

* The big black bear of the Himalayas is wrongly called Ursus Tibetanus, as it frequents the Indian side of the hills. It is called by the natives 'balu,' or 'reetch.' Its thigh-bones are like man's, and it can stand upright. The hair is very black and shiny, and it has the white horseshoe mark on the cliest. 
is nothing so human-looking as a bear after his skin is off. Having no tail, and hands with wide palms and arms like a muscular athlete's, not so disproportionately long as an ape's, he might almost be mistaken for a Herculean man. His feet also are ridiculously like a man's feet and leave quite a human impression. His legs are certainly short and bowed, but so are some strong men's. He is not quadrumanous like a monkey, but more nearly a biped with hands. His head certainly is not human in shape, but, when the skin is off, the skull is not so unlike that of a low-caste African's. His ears are similarly placed and his neck is equally muscular.

They build nests in trees, of which I have come across a good many, principally in tall oak-trees, like bowers made of evergreen boughs, and arched overhead to keep off the sun. They sit in them in the warm weather, a very sensible arrangement for getting the air. I have seen bears digging for ants and taking honey, and they use their forepaws and long nails just as a savage man might use his hands. Their food is mostly vegetable, as is that of the human race, though they also eat flesh when they are very hungry, and do not refuse the carcases of dead beasts which they may find; but they seldom kill anything larger than bees and ants. It seems rather a shame to shoot so well-disposed a beast, but they do an immense amount of damage to crops, and Government gives a reward varying from two rupees to five rupees for their heads. They are not admired much by the owners of cattle, as a calf is said to be sometimes carried off by a bara balu which has come on it from the thick jungle. One night, when encamped under a spreading mango-tree in which was a wild bees' nest, I was awakened by the shaking of the boughs over my tent, and went out in night attire to see what it could be. As I kept 
pointing the rifle up to the bees' nest, and waited to hear the sound or catch sight of the great black object where I guessed a bear would be, I suddenly heard close behind me a sniffing sound, just at my rear, and felt the hot breath of a huge bear as I swung round the rifle pretty sharply and let drive. There was no bear there after that, but next morning there were some very large bear tracks on the path, and the bees were in a state of immense excitement, and half their nest gone. There were big claw-marks on the tree-stem, but Bruin had not completed his robbery of the honey, but had scuttled off down the khud in the dark night.

The female bear sometimes suckles her young in a sitting position, like a biped, and her correction of her infants by giving them a sound box on the ear when they are disobedient, and scolding them in an angry, loud manner, is splendidly like the method of some impatient mothers. The young bears, of which there may be two or three, cry just like infants when corrected, and squabble and play together in a very human manner. I had several young bears at different times, which had been caught by natives by putting blankets over them, and brought to the cutcherry for the reward. They soon became tame and were very amusing, but were always ready to use their sharp nails in self-defence. If threatened with a stick, they would invariably put their backs against a wall or tree, and stand up like a pugnacious boy and box with their hands open, striking inwards at a furious rate. Nothing can resist the scooping, clawing stroke of a bear's heavy and powerful arms, delivered alternately on the object of his attack. A bear does not hug, as popularly supposed, but when he stands up whatever comes between his claws is literally made mincemeat of. There were many poor wretched natives in these high-up villages 
where bears were common, who had had the entire flesh of their scalps, heads, or faces torn away from the skull, and were the most ghastly objects to look at-those few, that is, who survived a bear's mauling. I cannot conceive a more frightful fate than to get into such clutches. Having been asked to prescribe for one or two cases, I could do very little to alleviate such suffering; but the sight inspired me with a proper dread of getting to too close quarters with Bruin. $\mathrm{He}$ is said to be a harmless vegetable-eater, and not to be difficult to shoot, and some sportsmen who tell very big tiger stories affect to despise bear shooting as not worth much; but I should myself always treat a bear with the greatest respect, go for him well armed, and shoot him as early as I got the chance, if possible in the white horseshoe mark in his chest, which is the surest place to get at his heart.

Bears seem to be nocturnal animals and rather shortsighted by daylight. On one occasion I came on two large bears grubbing for acorns on the side of a ravine. They went on with their occupation, not seeing me, though I attempted no concealment. I fired at one at about roo yards, and hit him in the muscle of the forearm. Immediately he felt the bullet he turned, with an awful yell of pain and rage, on the other bear, which was innocently following him, and gave him a tremendous hiding, the two roaring and rolling down the ravine together, luckily not in my direction. A female bear with cubs is by no means very safe to approach. She will perform great feats of valour in defence of her cubs.

The hill bear is a more dangerous animal than that of the plains, and fears man less, and will go for a man if he can't get clear away. I have hunted the grizzly bear in the Rocky Mountains, but much the biggest and heaviest bear I have come across was a Himalayan bear. 
He was shot near Pauri in Garhwal. We were three guns, and were posted at the bottom of a deep ravine filled with dense thorny scrub. The villagers commenced to beat from above, with tom-toms and horns, and threw down rocks till the bear, which had been damaging their crops, came out with furious grunts down the bed of the stream. We fired eleven bullets into him as he rushed along, but he seemed little the worse until he got one in his head at about two yards' range. The twelve bullets were cut out of him when he was skinned, but most of them had slipped round under the skin in the thick layer of fat which covered his great body, and had not at all penetrated his vitals. It took four men to carry away his skin, tied to a pole with the fat sticking to it. He must have weighed about ten hundredweight, and was a very old male. Most bears one meets are, however, only half the size of this one.

To return to our march. I had to cross rather a steep pass over one of the southern spurs of Nanda Devi. The tramp had been a long and tedious one, ascending through thick jungle all day. Near the summit there was a forest of old and weather-beaten pines, some white and hoary with age, their dead stems pointing to the sky. There had been breaks in the rain, and the sun had shone at intervals, and the air was close and oppressive. Immense black clouds hung and rolled up towards the snow peaks, and thunder pealed in the distance with ominous sound.

We hurried to get over the ghat before the storm broke. The villagers who carried the loads struggled on manfully. We crossed none too soon, for flashes of lightning became more frequent, and night was fast approaching. A deafening peal of thunder, simultaneous with a flash which seemed to pervade the air and blind and dazzle one's eyes, was followed by the crash of a falling dead 
tree almost over the path. Two of the coolies fell to the earth and groaned with terror. Nearly every tree near the top bore marks of lightning, being scored and barked from top to bottom. We instinctively hastened forward and down the steep descent, though all were deadbeat, and some left their loads and fled. Luckily there was a village some two miles from the summit called Migla, where our march ended; and the time taken to get there was a record one. The villagers had a great dread of that pass, and we were lucky to get all safe across. It seemed to be a favourite point for attracting the electric fluid, and to camp there would have been most imprudent. There are often high places which seem to be regular lightning conductors; and it is important before choosing the site for a house in the hills to study carefully the course of the thunderstorms and consult the natives, who know the bad spots, and generally have some rude temple or heap of stones erected to ward off the evil influence of the fairies or devtas which are the spirits of the mountains.

Thunderstorms often are seen and heard down in the depths of the valleys far below the level of the observer, but luckily these are not so dangerous as those which occur on the higher points. Thus, in the village below this summit the inhabitants had never heard of anyone being struck or any damage done by lightning; but on the pass many had been killed, and cattle were not driven to the jungle adjoining. We came to camp in a fairly open valley, where were broad fields of Indian corn in terraces all along the sides of the hills, the projecting spurs, which had comparatively level tops, being all cleared and terraced and cultivated. This was a large village of very industrious poor people, and not a yard of ground which could be reclaimed and terraced had been overlooked. Their houses, all of stone, were clustered together, and the 
lights could be seen, when evening closed, twinkling in numbers. The tents were pitched in a terraced field, and the natives gave us every assistance and supplies of flour, rice, ghee, milk, and firewood.

The headman informed me of their great troubles. The Indian-corn crops, which they took such trouble to sow and cultivate, were eaten up every year by the bears. Farmers always have some good reason why agriculture is a hopeless failure. The fields I had passed seemed to be most flourishing, the great stems of the corn, an inch or more thick, standing closely together and weighed down with heavy corn cobs. I had, however, observed that in nearly every field there was a machan or hut of some sort overlooking the terraces adjoining, and fires of logs were burning before the huts. These were for the watchers at night, who tried to keep the bears off their own fields by throwing burning logs at them and hunting them into their neighbours' fields, where they might graze in peace till the neighbour awoke and began the driving process. Bruin, though he got moved on pretty often, managed to take good toll out of most fields. These fields were not large, only patches of cultivation reclaimed from the jungle, with terraces supported by rough walls, exactly like those on the Riviera where the olives grow.

The night was dark and a steady rain falling. Presently a breathless voice at the tent door said 'Sahib, sahib, reetch ai gia!' ('The bears have come'). Seizing a couple of double rifles which were tied to the tent-pole, I handed one to the villager, who with a companion stood pointing towards the terrace next below. There was a crescent moon overhead and light clouds drifting across its face. There was just light enough to distinguish the shape of the terrace we stood upon, and the outline of 
dark tree-clad hills against the sky. Moving on about fifty yards, the leading villager, who was the owner of the lower terraces now covered with the tall stalks of Indian corn, stopped and pointed. I counted five black objects in the corn, and could hear them gathering the corn cobs and crunching the grain. There was no doubt they were five black bears at their evening meal, the nearest not twenty yards from where we stood; but it was impossible to see the sights of the rifle, though I tried several times. Oh, for a glow-worm or a luminous sight! But it was no use, I could not make sure of a foot up or down. I picked up a piece of shiny straw, and was laying it on the sight of the rifle to attract the eye in this darkness, when I heard a rushing noise through the corn, and the bear nearest me, no doubt smelling the gun or a strange scent, came straight on up the path to the terrace where we stood as fast as he could come. Whether I should leg it or not was the first question; but there was no time to get out of his way, and the flash of the rifle fired straight at him so blinded my eyes, and probably his too, that he came on the faster. As he tumbled up the path on to the terrace where we stood, I poked the rifle into the black mass and fired again. My friend the villager behaved like a brick and did not run; but before he could hand me the other rifle the bear, blinded again by the bright flash, was on top of us in a moment, and knocked down the man, getting past me I could not tell how, for it was all over in a moment, and Bruin rushed on as if the devil was after him, and disappeared in the darkness.

The only mark he left of his charge was a single claw mark, which took a piece out of my brave gentleman's nose. He took it very coolly, and got up laughing at the joke, and chaffing me for not stopping the bear. I had previously told him that I could not undertake to shoot in 
the dark, as I could not see the sights of the rifle, and that I would only shoot them by daylight. The other bears had all rushed simultaneously, luckily in different directions ; and next morning, as it rained all night, we could find no tracks of them. There was a great extent of very thick jungle all round, where bears could be hidden all day, not to speak of caves in the hillsides not easy to find; and, as I had no time to spend, I had to leave those bears unshot. Luminous sights for night use would be extremely useful.

Bears were very numerous from 1860 to $I 870$ in Kumaon, and on one occasion, when I went to Bagesar fair to buy ponies and yaks' tails and Tibet curios in the winter, I saw 400 black bear skins laid out on the ground round the Deputy Commissioner's cutcherry, for which he had paid the Government reward of four rupees each. I carried away many of those skins to make sledges for dragging away the earth on the Juli road works.

The survey of the Pindar river valley, from the glacier down to the junction with the Alaknanda, occupied some time. The river, fed by the Pindari glacier, which emerges from the vast snow-fields between Nanda Devi and Nanda Kot, is at this season of the year, when the snow is melting and the rains still coming down in torrents, a great swollen flood, sweeping onward at first between lofty snow-capped crags in a white and turbid stream. The valley opens out lower down, and in places there are cultivated flats near the river. The southern side especially slopes back from the stream in less precipitous curves, the hills, covered with timber up to their summits, forming very extensive forests. These slopes would be very suitable for sliding timber down with a view to floating in rafts to the plains, after the methods employed in Germany and France, in the Black Forest and the Vosges. 
This is a business which requires great skill, and knowledge of the various methods of timber transport; but it would be quite possible to train the hardy villagers of these mountains to the work. They already are very good axemen, and every hillman carries an axe, with which he can quickly fell the largest trees. The forests being all Government property, there would be no difficulty in exploiting the timber; and saw-mills could be easily constructed at the depôts, worked by the sidestreams coming from the lofty hills above.

Let me describe a typical hill forest in this region. First, starting from the Pindar river, where are villages with fields of rice and terraces irrigated by water-courses cleverly led from the side valleys, we ascend past fields of Indian corn nearly ripe, and clumps of great-leaved plantains laden with fruit. There are lemon-trees and apricots, figs and wild cherries, and luxuriant mulberries and shady evergreen mango-trees, some with great stems very old and twisted. There are several kinds of figs, the sacred pipal and banian. Higher up, following the villagers' paths by which they drive their cattle to pasture, we come to enormous walnut and sycamore trees. The walnuts are collected by the natives and stored in great quantities. Presently we strike into forests of evergreen oak of three different kinds, several kinds of acacia, and many sorts of underwoods, berberis, and wait-a-bit thorns.

Higher up, at about 8,0oo feet elevation, we get into the real pine forests, which grow best on the less steep northern slopes where the sun does not glare. They prefer to live under the shadow of the great mountain, where the soil is black and deep, and many bulbous and flowering plants, ferns innumerable, and shrubs of the azalea and magnolia type abound. There are clusters of yew 
and box, and wild vines and all sorts of rare flowers. The southern slopes have quite a different set of trees and shrubs, the great scarlet-flowering tree rhododendron being resplendent.

It is delightful to camp in the cool regions of the pine forest after the rains, when the climate is splendid. The tent is pitched by some gurgling stream in a little dell, where there is a smooth turf for the tent, studded with scarlet potentillas and innumerable lovely flowers, and bordered by maidenhair and other feathery ferns, of which I have counted fifteen kinds in a space of twenty yards. Clumps of graceful ringals are placed on the slopes just in the right spots to form a most perfect landscape garden, with never an incongruity, such as artificial ones are ever presenting. The great gray stems of splendid pines (Pinus excelsa) stand dark with deep shadows cast on the verdant sod. There are groves of enormously tall cypress, straight, and I5o feet high, with sharppointed tops, all of different ages and heights (not uniform as in plantations), thinned out only by storms and old age. Then, in the more sheltered northern breast of the mountain, stretch miles of the lofty raga forest, silver firtrees like masts, and 12 feet in girth, towering to the skies and standing close together; and there are alternate groups and stretches of the elegant weeping spruce, dolchella, even taller and grander stems. There are single trees standing in the open and at the edges of the forest, absolutely perfect, with every branch in its place, curved and drooping to the ground, more picturesquely placed by Nature than by the most artistic lover of landscape gardening.

The middle ranges of the Himalayas are being exploited for tea planting. The climate and soil are so varied that the plants of all countries are represented, and almost anything will grow if its proper region is found. Among 
other valuable products the tea-plant was found by Robert Fortune, who introduced it from China, to thrive excellently at an elevation of from 3,000 to 6,000 feet. The Government, with the object of encouraging this industry, established several experimental tea-gardens, which were proved to be very successful.

Among others, that at Pauri in Garhwal was worked up to I86r by Government, and then sold to a private planter. The industry was encouraged so as to induce settlers, principally retired officers, to embark in teaplanting. There were several most thriving plantations in Kumaon. Sites were selected where the villagers had not utilized the land, and where jungle could be cleared away. On the lower ranges south of the Pindar river there were several fine plantations, at Duara Hat, Dunagiri, Ranikhet, and other places. Native labour was easily procured, and the slopes of the hills cleared and planted, Government giving grants of seed from its gardens in Assam, mostly China seed. The variety discovered by Fortune in Assam was also tried, and found to succeed even better and produce a larger crop. The plant is a small-leaved, white flowering evergreen, a sort of camellia. The seed is large like a hazel-nut, and germinates rapidly during the rains in seed beds, being fit to plant out the second year. The plants are then put into the garden in rows about 5 feet apart, and grow rapidly, producing tea from the fresh sprouting leaves early in spring, and again in summer and rains. It was quite an agreeable surprise to come across a plantation in the midst of a wild jungle, with its well-tilled slopes intersected by paths leading to the cha godown, where the leaves were rolled, fired over charcoal, and manufactured. The planter's house, built of native stone, with its wide verandahs, was usually placed in a most picturesque 
situation, with extensive view of endless forest-clad ranges and valleys sloping away, and the distant snowy mountains standing grandly against the northern sky. The life of the tea-planter, with his family and with constant occupation, is not a bad one. His home is in the midst of beautiful scenery, and his opportunities for shikar are endless. The higher up the plantation stands, the more highly flavoured is the tea; but the quantity grown is much greater in the hotter, low-lying positions. The low price of tea has much reduced the profit, but at first it was sufficient to meet the local demand in order to pay its way. The flavour of Kumaon tea is notoriously excellent. Its fine perfume is easily distinguished, and if not made too strong it is quite the best tea that can be partaken of.

The hospitality of tea-planters was notorious, and was a pleasant variety in a life in the forests. The depreciation of silver benefits the tea-planter considerably, as his labour is paid in rupees and the tea sold for gold. 


\section{CHAPTER XV}

\section{THE GREAT CHIR PINE FOREST}

LET us wander through the ranges of the middle Himalayas, which we may call the semi-tropical zone, where the chir pine flourishes everywhere at an elevation of from 4,000 to 6,000 feet. The Pinus longifolia is a tree peculiar to the Himalayas, and has an extensive range from Nepal to the western Punjab. More especially on the southern faces and tops of the numerous ranges, on the sunniest slopes, these handsome pines, with tall, straight, red-coloured stems, grow to the greatest size, and cover hundreds of miles of otherwise bare and grassy hills. The spines, in clusters, measure 12 to $x_{4}$ inches long, and are bright green, huge aigrettes of shiny foliage forming umbrella-like heads, somewhat like those of the Corsican pine, and bearing similar great knobby fir-cones, with big seeds.

The Forest Survey shows the area of forests surveyed in Kumaon to be 433,95 I acres, and in British Garhwal 253,472 acres; total 687,423 statute acres, equal to I,074 square miles.* The area of chir alone is 152,264

* The areas given in the reports are :

Acres.

Pinus longifolia (chir) - - - _ - 152,264

Pinus excelsa (dolchella) - $\quad$ - $\quad$ - 14,000

Pinus Brunoniana (tungsing) - - - $\quad$ - 1,000

Picea Webbiana and Pindrow (raga) - - 53,820 
acres, and the usual number of measurable trees per acre is about twenty-eight, being seven trees of the first class, and seven each of the second, third, and fourth classes per acre, besides seedlings. The firstclass trees are over 8 feet in girth, and some chir-trees measured I4 feet in girth and I4O in height. The age of such a tree is computed from the rings to be 260 years, and a second-class tree of 6 feet girth takes 160 years to grow to that size. The timber of the chir is like pitch pine or red pine, beautifully grained, and very strong and durable under cover. It is full of turpentine. All the roads which traverse the lower hills (generally bridlepaths, following the ridges and contours as much as possible to avoid constant descents and steep ascents) pass through miles and miles of the familiar chir forest; and the recollection of those fiery-hot and almost shadeless miles over dry and heated soil and rocks is burnt into the minds of all hill travellers. The ground at certain seasons, before the grass has been burnt over, is covered with the spines or leaves shed in the spring season, and these are so slippery that it is doubly tiring. The heated air is drawn upward by the sun, and whistles and moans through the branches, and the glare from the ground is scarcely modified by the scanty shade from the loose, feathery tree-tops. No underwood grows, as the annual fires, fed by the turpentiny leaves, make a clean sweep of all young vegetation except the grass, which is of a harsh and slippery sort. No one is likely to forget the chir forest, with its heat and wearisome monotony. Yet it is beautiful, and the distant blue ranges through the red stems and the 
light-green foliage of the young trees are charming to the eye. Above the chir comes the dark evergreen oak forest with rhododendron up to ro,ooo feet.* Below the chir come the tropical jungles of sal and palm and acacias.

The chir timber is extensively used for all building purposes at Naini Tal and the other hill stations, and makes capital rafters, beams, and flooring boards for house building; but it never fails to twist a bit when seasoned. The forest extends all along the valleys of the great rivers Alaknanda, Dhauli, and Sarju, where timber can be floated down to the plains.

The principal wild animals found in the chir districts are the gooral, $\uparrow$ or Himalayan chamois, and leopards, which are not uncommon, the former living on the very steep and rocky slopes and precipices, the latter in caves.

The small tent is pitched near where the gooral frequent, in herds of three or four together or singly. They are found in the very early morning and late in the evening grazing on the slopes. In the day-time they hide under rocks on the face of the steepest khuds.

Awaking before daylight, we are out on the slopes below the camp when the first streak of dawn appears, touching up the mountain tops with a roseate glow. The climbing is difficult on the slippery grass slopes; and paths made by the sharp feet of the gooral must be followed in order to get round the spurs and buttresses of the hill, clinging on for bare life to bits of jutting rock, and keeping a good look-out when rounding the points of the ridges. It is slow work, and our native shikari is all excitement to catch sight of the game. Their dull,

* Qucrcus incana (banse), common; silver under-leaf.

Quercus floribunda (tillonge), a fine tree.

Quercus semicarpifolia (khersoo), grows to a great size; fine timber.

+ Nemorhadus goral. 
yellowish colour makes them hard to see against the burnt and yellow grass and gray rocks. At last we round a corner, and on the next ridge on a jutting rock there stands a fine old buck, about as big as a goat, sharp against the eastern sky, there being just light enough to sight him. There are three others with kids, grazing on the slope between the rocks, quietly picking at the greenest spots. They are within easy shot, but the buck is the more tempting, and he is over roo yards away. Presently they move upwards, as if scenting danger, and one gives a short, sharp sort of sneeze. There is no time to delay, so we put up the Ioo yards sight and take a steady shot at the buck. He is struck, and falls straight down into the khud below. The females dart with frantic speed down the slope, and disappear with desperate bounds apparently into clear space.

The gooral, sometimes called ban bakri-' wild goat' -is about the same size as a chamois, and resembles that animal very much; but is, I think, a somewhat slighter and less angularly built beast. The horns of the chamois are set at quite a different angle, pointing much more forward, and the curve is more of a hook. For eating purposes they are much alike. Having stalked and shot both, I consider the sport very similar; but the gooral lives on grassy slopes preferably, while the chamois delights in rocky precipices near the snow-line, corresponding in that respect with the more alpine thar. The gooral has no beard, and its tail is black.

To bring him to bag it is necessary to be a first-rate cragsman, and to wear either boots, with big nails or spikes, or grass shoes. On first ascending the hills, the passage along the edges of the khud is rather alarming; but custom soon steadies the nerves, and the most timid will look down enormous depths with perfect callousness. I possessed several gunt ponies, and they all preferred to 
walk on the very edge even where the path was wide; it seemed their nature. Riding day after day with one leg hanging over space, and only the sure-footedness of a pony to rely on, became the ordinary condition of travelling. Only once have I known an unridden pony to go down, and that was on a gravel face where the bank gave under him. He retained his balance and slithered down about 30 feet, and pulled up on a ledge of grass, where he grazed unconcernedly. Once when riding up a very steep place, where a narrow path led over the head of a quite perpendicular khud, where I should have dismounted but for a strained ankle which I was saving, my best gray pony, a stoutly-made Bhotia, about I3 hands, with unshod feet like iron, scrambled on the brink. I slipped off on the hillside and tried to save the poor beast, but he could not recover his legs, and rolled over twice before he was pulled up against a small chir-tree just overhanging the precipice. We climbed down to him, and I tied his leg to a root to help him to stick. His head was out overhanging the khud, and he lay quite still, every muscle strained to keep his position. The syce ran to a village for ropes, and brought men, who pulled him up again none the worse. He neighed to me when I praised him for lying so still. He was a good and faithful companion, who accompanied me on many marches. When riding a long $d a k$ quickly, I usually took two ponies. I rode one, and the other trotted on after, unled. When one had done his share I changed to the other. When walking, it was advisable to let one go ahead and the other follow, as if both ran ahead they would sometimes go too fast, and one had to walk further than one wanted to. One syce was usually sent on running some hours before the start, and the other ran behind. Thus thirty miles could easily be done in a day, or forty at a pinch. 
After dark, leopards occasionally gave trouble. The ponies occasionally snorted and refused to go forward, smelling a lurking tendua or panther. Cracking a whip and shouting generally kept him at a respectful distance. I have several times at twilight seen a leopard cross the path, and once one tried to spring on my dogs, who ran at my ponies' heels. They saved their lives by running under the ponies' legs, and by shouting the leopard was scared off.

Leopards are beautiful and graceful animals, the picture of cunning, audacity, and slinking timidity combined. They are very common in the lower jungles and chir regions-indeed, everywhere over the hills. Different localities seem to be frequented by different varieties of leopard or panther. I have shot the large variety several times among the lower hills, and also seen and shot a much smaller leopard in Gorakhpur, with longer tail, and bullet head, and spots more concentrated. I reared a young leopard which was brought to me in the Kangra valley; it was a nice pet, about as big as a cat, and it used to delight to sit on my knee and purr; but one day it met all its claws in my leg for sheer sport, which I did not appreciate, and eventually it became savage, and if it got a piece of meat it would behave nastily. I fed it on bread and milk, but it died in the rains.*

One evening nyy two spaniels rushed inside the tent growling and snarling, and the chaprasi, who luckily stood at the door, sang out 'Bagh, sahib, bagh!' $\dagger$ Coming out,

* Felis Pardus or Leopardus of Jerdon, called 'tendua' sometimes, also by the natives 'bagheera,' and in the hills 'lakha bagha,' a name more properly belonging to the hyena; also 'chita' in the plains, which name belongs rather to the hunting leopard, Felis jubata, which is a very distinct species.

+ Natives always apply the politest terms they can to what they respect. Thus, a tiger is often put up a degree higher and called a lion, 'sher.' A leopard is called a tiger, 'bagh.' 
he pointed to where the leopard had sprung, nearly to the tent door, before disappearing among the bushes. I tried long to sight him crouched in the shadow, but failed to see him. To draw him out, I tied a white kid on a bank to a bush, and waited with the rifle ready. It was now getting dark, but I saw, as I thought, the kid spring up the bank, only the long tail was not that of a kid. It was too dark to distinguish anything but the form of some animal, so I fired at the beast and saw it spring away into the bushes untouched; but in the instant it had killed the kid, which I examined and found dead. There was a little native chappar, where a native was cooking his evening meal and a small fire burning. In this I crouched, and got a better view of the white kid lying about six yards off. Presently a dark object seemed to glide across the white kid, and it had the round form of a leopard's head, crouching almost flat; the long body could just be made out. Taking a bit of burning charcoal, I placed it on the rifle end to act as a front sight, and found no difficulty in placing it where the beast's shoulder should be, and fired. The result was some very ugly grunts and roars, and a scrimmage could be heard among the bushes on the bank, then some kicks and groans which sounded like the end. My bearer got a lanthorn, hung from a long bamboo, and lowered it over the spot, among rocks and jungle, while I pointed steadily with the rifle to make sure he should not be alive and able to spring; but no movement came, and at last we could see the spots and form of a fine leopard lying dead, and no mistake, among the rocks. This was a great joy to the syces and camp followers, who had for several nights been annoyed by this leopard prowling round. Several times the horses had jumped and broken their heel-ropes in the night. The goats and sheep had had a rough time, two of them 
having disappeared, and the poor dogs had been unable to sleep for watching. The khansamah, when cooking by his fire, had seen a big leopard lying on a rock just above him, outlined against the sunset sky. This was a fairsized leopard, or panther it might be called, and its skin was a beautiful one.

Shortly after that, the villagers reported having lost goats and calves in a valley not far off, where was much scrub jungle, rocks, and a river of clear green water flowing by, with deep pools and khair-trees on the flat. They brought word about two o'clock one day that a buffalo calf had just been killed, and its blood sucked from the neck by a tiger or a panther. Going at once, I climbed into the fork of a khair-tree, the only one available, just three yards above the calf, and sat there from three till six, rifle to shoulder pointed at the calf. It was the cold season, and not too hot. Dressed in khaki-coloured jacket and preserving an immovable attitude, I hoped to remain unobserved, as leopards do not often look up into trees. The wind, gently passing up the valley, as it always does in the afternoon, would carry the scent clean away. It was tiresome work sitting still, but I had secured a firm position by placing a few cross boughs in the fork. The sun sank behind the hill, the breeze fell to a calm, and silence reigned. The birds, having finished their screeching and flying round, were thinking of going to roost; some jungle fowl were running through the tufts of long grass on the sand by the black stems of the feathery acacia-trees. There sounded through the stillness a hollow 'Ooh, ooh' from the hillside across the river, whence came the continuous musical murmurings of the stream flowing among rocks. A second similar call, somewhat louder, but in the opposite direction. The sound was like a ventriloquist's voice, and seemed to come 
out of the air. It announced, surely, the coming of the wily depredator, whatever he might be. It must be a large animal to kill a buffalo calf. My tortures of sitting motionless, with strain on the eyes and ears, soon came to a climax, and a very large panther walked coolly up to its prey with the usual cat-like, gliding stride. As I slightly turned the rifle to point it, the panther's wideopen yellow eyes caught the motion, and he stared for an instant straight in my face, at the same instant raising his lips and showing his white teeth in a fierce snarl. But at the same moment I covered him between the eyes, and let off both barrels. The bullets both entered fair into his brain, and he fell with the usual hollow roar. This was a very fine male panther, measuring $8 \mathrm{feet}$, and very fat and heavy.

I often spent several hours of day or night sitting over a kill, with more or less success. Most frequently in the dark the leopard or tiger would come and eat some of the carcase; one heard the bones crunching, but could see nothing. I fired at the sound, sometimes getting nothing, or perhaps wounding only; sometimes getting a skin. On one occasion a leopard came across the muzzle of the rifle about one yard off. There was only a thick clump of bushes to sit in. The bullet went clean through the leopard, and he fought and roared on the ground, much too close to the bush for one's pleasure; but he got up and slunk away, and died in an adjoining cave. This was in the night. Once $I$ was with a very enthusiastic R.E. lieutenant, who was eager for blood. A tiger had killed two cows, and we tossed up for places to sit. The tiger came in broad daylight, and I saw the yellow hide and the stripes through some bamboos, moving slowly across. He did not, however, come to either of the kills, and we found afterwards that there was a third cow lying fifty 
yards further off, where he spent an hour eating and tearing the meat off the haunch of his victim, while we tore our hair with disappointment at not getting a shot.

It is surprising what numbers and varieties of beasts, birds, and reptiles frequent these various regions. To describe them all is the work of a naturalist, but to wanderers in the forest new plants and animals are an endless source of interest. Of birds I may mention the lammergeier, which sails round and round the tops and faces of the cliffs on extended wing, ever soaring without apparent motion of its wings, which measure Io feet from tip to tip. I have often watched half a dozen, perhaps, of these great eagles passing quite close to the cliff where I stood, so close that I could see the bright big eyes, the great, powerful hooked bill, the rufous, tawny markings on the yellow feathers, the crested head, and the cruel talons gathered up under the breast. 


\section{CHAPTER XVI}

FORESTS OF THE BHABAR AND FOOT-HILLS

THE great sal forest covers the dry hot regions of the foot-hills and the Bhabar, which extends in a belt of from ten to twenty miles wide the entire length of India, from the Punjab, where it is less developed, right away through the North-West Provinces, Oudh, and Bengal to Assam and the Brahmaputra, clothing with its dark, dense foliage the whole of the foot-hills up to 3,000 or 4,000 feet. It is probably the most extensive forest of one particular tree in the world. It grows also - or rather grew, for the woodman's axe has laid low all the fine big timberin portions of the Central Provinces, Nagpur, and the Mysore hills and Tenasserim. Sal* has always been considered in India the most valuable of timbers, even stronger and heavier than teak. It is a dark-brown, closegrained, hard wood, with straight interlaced fibre. It is used in the gun-carriage factories for the limbers, and is considered the strongest and most durable timber. It had been so extensively used for building purposes, carpenters' work, and latterly for sleepers, that the great trees which abounded all through the forests had disappeared, and nothing remained but saplings and young trees, all growing as close together as possible, their straight black stems and shiny green heads forming a complete thicket. Occasionally, in the inaccessible places

* Shorea robusta according to Roxburgh, also Vatica robusta. 
and the steep hillsides one saw a mature sal-tree. It is a grand and noble stem, straight up with scarce a branch. I have seen some I 6 feet in girth, sound and healthy, 60 or 70 feet in height, with straight stems to first branch. It is impregnated with a resinous, highly scented juice or gum, which the natives draw from the stems, called ral, which is like pitch, and is put to similar uses. The timber will stand the severe changes of heat and moisture better than most other timbers.

I will now describe a day in the Bhabar. We start on a single pad elephant from Haldwani, on the southward road, to Bareilly at the foot of the hills. Haldwani was an oasis in the dry Bhabar, for here had been constructed by the paternal Government of Kumaon straight canals, leading from the hills, which carry the life-giving fluid for irrigating great tracts of the Bhabar reclaimed from the forest, where, thanks to the kind old Commissioner Ramsay, there were hundreds of acres of cultivation, settled by thriving and industrious Kumaonis.

The elephant tramps along the edge of the water-course over the gravelly flat, taking the first straight track between flourishing crops, towards the nearest edge of the forest, which stands up to the south-east, a straight line of sal-trees. Soon we enter the jungle, and soon we are lost among the trees and long grass, which the elephant can just force his way through. We keep going eastward, and on goes the elephant with long strides; truly he has room enough to step out, for the forest extends in an easterly direction by south for over I, ooo miles, with few intervals. The forest gets opener, and the sal-trees, which have been protected by the same good guardian, the Conservator of Forests, for some years, have certainly benefited, some being 40 feet high and growing healthily. There are immense numbers of fine seedlings 20 feet high, 
and in time there will be sal-timber galore. The sunlight glistens on the shiny leaves, and its heat is pretty strong, baking the dry soil where the grass has not grown very thickly. For there is no water in the Bhabar, not a spring nor a stream nor even a trickle in the many dry watercourses which we cross; the elephant stumbling over the rounded stones and boulders, for elephants cannot comfortably tread on gravel and stones.

The great body of water which is flowing down the rivers from the Himalayas is all underneath the surface, filtering through the gravel beds, to break out again in the Terai-new sources and new rivers. This goes on in the dry season; and the great rivers, the Ram Ganga and the Sarju, are then only small, shallow streams. But in the rains, when the great water-gates are loosed, then all the rivers flow in full channels with swollen yellow torrents, surging and ever pressing onward to join the great Ganga. The result of the tropical monsoon rainfall of Ioo to 400 inches is that the stuff which has been washed down the river valleys is now spread out in great gravelbeds at the foot of the hills. The materials are sorted out, the heaviest boulders and stones being carried the shortest journey, the less heavy ones next, and the lighter stones, gravel, and sand spread out further over the plains; till, lastly, the more soluble clays and silt are deposited, forming the 'Terai.'

The filtering of the water through gravel-beds over I,000 feet thick ought to make it very pure and wholesome. Unfortunately, it soon gets stagnant in the swamps and sluggish mud-streams lower down. The Terai, like the Roman Campagna under the Alban hills, which is a similar formation, is celebrated for its deadly fevers, which are worst in the autumn, when the rains are drying up. But, strange to say, the dry and stony Bhabar is 
even more unhealthy, though there is absolutely no water. It may be found that the mosquito is answerable for the fevers in India as well as in Italy. There are plenty of mosquitoes in the Bhabar after the rains; in December the frosts begin and kill them. At that time fevers cease. The natives of the Terai are so naturalized to the fever germs that they cannot live elsewhere. They usually carry a piece of arsenic, from which they scrape off a little daily with a knife and take some grains, which, they say, keeps off fever. Garlic, onions, and asafœtida are also taken in their food for the same purpose. Plainsmen and paharis generally die if they sleep in the Terai before November I or after June I.

To return to our elephant ride. Turning to the south. the jungle becomes of a different character, less timber and more grass. The grass is now Io feet high, and no man on foot could get through it. In the winter months the natives who graze their cattle in the forest take care to burn all the long grass, so that young green stuff may spring from the roots. We come across the line of fire, which is advancing across the forest, generally against the wind ; but there is very little wind, and the fire moves on so slowly that no one seems to be afraid of it. The elephant walks quite unconcernedly up to where the flames are crackling and roaring 20 feet high. The insects suffer most, and flutter up before the flames, a crowd of poor scorching moths and butterflies. The king-crows, black birds with forked tails, and fly-catchers, and even kites, are seen feeding on the insects close to the flames and smoke. It does not at all come up to the harrowing description of forest fires one has read of in books. This may be owing to the absence of wind. We shape our course by the compass if the hills cannot be seen, and the elephant now swings along over the open, blackened 
ground more easily. The sal-trees seem to suffer very little from the fire, their bark being thick and sappy, and their leaves tough and high up above the flames; but in reserved forests it is advisable to exclude fires, in order to give seedlings a good start. Further south we come on glades in the forest in long strips, the whole plain southward being a sea of still unburnt grass. Trees, also, of various kinds begin to take the place of the sal. There are saj, semal, dhak, khair, sissoo, and jamun, besides other kinds.

In these glades, where the grass is not more than 4 or 5 feet high, many deer find covert. The elephant moves so silently that the herds of deer couched in the grass almost permit him to walk on top of them. Then, with a rush, they slink off, scarcely showing their spotted backs and slender, graceful horns above the covert. There is the axis, or spotted deer, about the size of the fallow, but with round-not palmated-horns. These were so numerous that every few minutes one could see the motion of the grass, where numbers were started. Pigs, also, and hog-deer are started. The former lie in the grass, an old one, perhaps, with a 'sounder' of ten or twelve halfgrown young pigs. They make mounds of cut grass and sleep in the nests thus formed. The grunting and the determined rush of a sounder through the grass are disconcerting to most elephants. Nilghai also one occasionally met. Their dark-blue backs are more easily seen galloping through the jungle. An occasional tiger who is out stalking the deer may by chance be stumbled upon. I have myself shot a very fine tiger from a pad, by a lucky shot as he rushed across a path.

Here is a wonderful preserve of big game. During the rains they have perfect safety, and without elephants no man can find his way through this sea of grass. 
The further one goes southward the more restricted become the timber belts, and the open, grass-covered plains of the Terai lie stretching to the horizon. In this region is found the barasingha, or big 'twelve-tined' or swamp deer, but further east, in Nepal, he is more common. He is as large as the sambur and much bigger than a red deer.*

There are several herds of wild elephants in these forests. The great paths made through the long grass by these beasts, lead for miles through the jungle, showing there must be a considerable number. They are not allowed to be shot, being too valuable and scarce. They used to be captured by the Government kheda, but are now allowed to roam in peace. They frequent only the Bhabar belt and the lowest foot-hills, coming up into the narrow valleys where water streams flow, and where there are no human inhabitants, and where the jungle is dense and pipal-trees are found, on which they feed. Coming out on the road cut through the forest, leading southwards to Bareilly, as the evening approaches, we follow it northward, returning to Haldwani.

The trees have been felled well back from the great wide road, so as to afford no covert for wild animals too near its course. It runs perfectly straight in both directions as far as the horizon, going away in distant perspective. As we get nearer to the hills the view is remarkable. The forest opens out into a wide park, with occasional groups of various trees, the yellow grass forming the foreground. Beyond is the long line of dark sal forest, and above it there rise in faint blue outlines the summits of many forest-clad mountains, fading away into the dim distance. Then comes, as it were, a sky of purply blue, the warmer tints of orange and red pervading it when the evening approaches. Suddenly, as if by magic, right above, 
higher than one would ever expect to see such a vision, the snowy range stands out, a lovely panorama of white peaks cut out with blue shadows, standing in cold majesty against the heavens. I have seen a similar effect across the prairies when approaching the Rocky Mountains ; but for striking effect and mysterious beauty the view from the Bhabar or Terai, only occasionally seen, is unsurpassed. What wonder the Hindu of the plains looks on these great mountains as the divine habitation! $\mathrm{He}$ cannot believe that man can exist and walk up there, or that water can harden into those white snow summits. He prays towards the sources of his sacred river as the most divine fountain of life, and he worships its everwelling waters as the stream which will bear him eventually on its bosom to Paradise.

It was under the same mysterious mountains further eastwards, at Gaya in Bengal, that the religion of the Buddhists had its origin, and the sacred Bo-tree is still shown under which Sakiya Muni received the divine revelation. Prior to these inspirations, the worshippers of the fairies, found and still surviving in all countries, seem to have peopled every rock and summit, every fountain and torrent, with their mysterious spirits or deities, who must be kept in good humour and flattered lest they may do us harm. Snake worship is also not uncommon, with which the allegory of Eve and the tree of knowledge may be connected. In these hills, as well as in the Celtic countries of Europe, are found heaps of stones, where the passenger throws something to appease the devta or fairy of the ghat. The bush near the sacred well is covered, as in Ireland, with rags tied on to please the deity. I have often, in the least-frequented ranges of the Himalayas, come on heaps of loose stones put up on the summit of the hill; also altars, where rice and 
food is placed and offerings to the deity. Very frequently an iron model of a bow and arrow is seen placed by a shikari to propitiate the devta, so that he may succeed in bringing game to bag: otherwise, as he tells one, no game will be shot.

It is remarkable how suddenly the change comes, when one reaches the foot-hills, from perfectly flat plains to precipices and rocks and perpetual declivity, where a flat place to pitch a tent is scarcely found. The forest which clothes the spurs and valleys in the foot-hills is much less injured by man, and as we get up into steeper and more inaccessible places it is often quite natural and untouched. We must climb on foot, and follow the natural paths where wild animals travel from their pasture to water, mostly along valleys by the clear green running water, or along ridges, till we gain a higher standpoint, above which we are sure to see another ridge or summit towering miles ahead. It is sweltering hot, but there is shade abundant. The air begins to move upwards as the sun warms it. Early in the day there is no sound but the rustle of a slight air through the leaves. There is no lack of wild animals in these beautiful forests; even elephant tracks are sometimes met with, old ones made during the rains. But there are fresh tracks, the $k h o j$ of a noble stag, the jerow, ${ }^{*}$ for this is the haunt of the great six-tined deer. In these unfrequented foot-hills I have stalked him frequently, and observed his habits during years. He has very big ears and eyes and nostrils, and all his senses are highly

* Rusa Aristotelis according to Jerdon; called 'sambur' in the plains. Called by Aristotle, in his 'History of Animals,' the horsedeer, because he may have been thought as big as a horse. His size, according to Jerdon, is: length, 6 to 7 feet; height, I 3 to I 4 hands. Some give a larger size. The horns lack the beam or royal antler, and seldom have more than six points. It is found in all India, and up to Io,000 feet in the hills. 
developed from being constantly on the watch for his enemies of the feline race, tigers and leopards, which with velvet tread are always stalking him. No man with boots on has the smallest chance of approaching him, except round the corner of a spur. He can see in the dark better than any man-even a wild man, whose eyes are always in practice. A bare-footed man, or one in gum-shoes, might once in a way get within shot of him. I have shot a good stag from an elephant at 20 yards' distance, as he stood up from his lair and stared at the animal I was riding. I fear this was taking a very mean advantage. But while one goes along on foot, no matter how quietly, to get a shot in the forest and slay a stag sambur is a feat of stalking rarely brought off. I once did bring one to bag in this way; but he was a very old stag with only one eye, which was turned away from me as he stood listening across a ravine. His horns, which I still possess, are the largest I ever saw, measuring $43 \frac{1}{2}$ inches in length, $43 \frac{1}{2}$ in spread, and $8 \frac{1}{2}$ in circumference of beam. He was shot in the Central Provinces. The jerow of the hills is exactly the same animal, but the usual size of antler is much smaller than the above.

The colour of stags is dark-brown-almost blue-black sometimes, with rufous and yellow underneath. The hinds are light fawn. To shoot a hind I considered unsportsmanlike. I spent many happy days in the foot-hills stalking the jerow, accompanied by a single bare-footed, almost naked Dotial coolie named Jugia. He was a most silent, cat-like young man, strong and lithe of limb, and had eyes that could see through a thicket in the most wonderful manner. I promoted him to the honour of carrying my second rifle and luncheon basket, and he was worth twenty professional shikaris. He would watch the motion of my hand, and was always ready with the rifle. 
He turned out a most faithful and valuable attendant, and accompanied me to other districts.

In a side ravine, which was separated from the main valley by a ridge of high rocks, I came suddenly on a brace of big jerow stags fighting. They had not heard my approach in the heat and noise of the scuffle, their horns being locked together and rattling loudly. I watched them some time from behind the rocks before firing at the biggest. They rushed away in different directions, thundering down the steep hillside. Though shot clean through the heart, the stag ran 200 yards before falling. I once, in the Bori forest, found the skeletons of two stags with horns locked together, both of which had fallen victims to a deadly fight. Some of the old stags attain a great size and weight. I have shot the red deer in the Harz Mountains, and the wapiti in the Rockies, and find the habits of all three very similar. The sambur or jerow is a good half-way size between the other two. The horns, are, however, not to be compared with those of the wapiti, and 40 inches is a very big average length; but sometimes one meets with very thick horns up to I2 inches in circumference.

I had the good fortune several times on these tramps to come across another animal peculiar to these jungles - the serow* or jungle antelope. He is horned like the gooral, but twice as big, and looks like a short-eared donkey. They have callous, horny knees from constantly lying on rocks, and their hoofs are strong and legs thick and adapted for climbing over rocks. I have found the serow at 3,500 feet, and never as high as Dr. Jerdon places him. He is not a graceful, bounding antelope, but shuffles along, generally down the khud, when disturbed, at a tremendous pace.

* Nemorhadus bubalinus. Habitat, according to Jerdon, from 6,000 to 12,000 feet. 
He will sometimes, when cornered, run at a man with a vicious snort, and is not at all timorous or easily removed from his favourite ravine, which is usually a complete thicket. When approaching such ground, one must climb over rocks and into stony channels, all sloped at a high angle, stooping under boughs, creeping between stems, and keeping one's rifle ready. There are paths worn by horny feet, and large round droppings. We clamber down one ravine, I and the faithful Jugia. We creep noiselessly, ears and eyes on the alert, round a point into another gully, following the path leading upward. The heat is intense, but there is shade and broadleaved foliage of trees and twining creepers. We hear the sudden clatter of a beast coming towards us down the ravine. We stand immovable, but all excitement to know what is coming. Another rush and stones falling, then silence. Just above us is an animal crouching nearly to the ground, its strong legs straddled out as if ready for a rush, its body half concealed among the branches. It has ugly, sharp horns, and a sly, hostile expression in its startled eye. Its black nose and shiny nostrils extended motionless about Io yards above us, it seems about to rush; but the silver bead of my Westley-Richards bore on its neck, and as it sprang forward the bullet sped-a I6-bore with hollow tip-and crashed into the jugular. We stepped aside to let it roll by head over heels, till pulled up against a rock. I have several times seen the serow in similar jungle; but it is an animal not easy to get, as it generally escapes unseen in the thicket with a rush.

On such climbs among the foot-hills one may come across any sort of game, from tigers downwards. On one occasion I passed unknowingly within about five yards of a tiger which was lying in a cave. I got a 
glimpse of him moving away after I had gone some distance.

Sometimes I spent the night sitting in a sort of nest, made with soft boughs in a forked old oak-tree, right on the top of a ridge commanding a ghat or pass-way from one large valley to several others, with a blanket to keep out the night chill. Most delightful nights they were in the dry season, with scarce a breath of wind, and the bright stars shining overhead, and complete solitude. The beasts often began to stir about 3 a.m., signalling to one another by signs only known to the jungle inhabitants, all having their own separate language and each its own interests to look after, often conflicting. The deer would seek the green pasture about 4 a.m. to take their morning meal, and, having filled themselves, about daylight would be on the move for the thick jungle, where they would harbour for the day. A big stag might seek a salt lick, where he would satisfy his craving for such condiment. There were several I knew of. There were places in the forest where stags would soil, rolling themselves in mud. An old bear might come lumbering along, turning over stones and picking up insects, and scraping out ants' nests with his claws like gouges. Later, a hideous striped hyena,* with hang-dog expression and humped-up back, would come along in a hurry, making for his favourite cave, as if he thought he had stopped too late crunching the bones of a poor cow that the tiger had left only partly eaten. His unearthly call to his mate had been heard in the night. Beautiful dark rufous-coated martens, $\uparrow$ with long, bushy tails, would chase one another through the branches of a great saj-tree. Jackals and little hill foxes went by on their midnight prowl, sometimes making the jungle

\footnotetext{
* Hycena striata (Lakha bagha). + Mustelu flavigula (Jerdon).
} 
re-echo with their dismal howls. The sounds of numerous birds awakening came from the jungles below. Then all became quiet again.

The langur monkeys told one a lot of what was going on at daybreak. They frequented a cluster of great mango and semal trees which surrounded a ruined temple in the valley below. They seemed to know exactly where the tiger spent his time, and gossiped perpetually about the two bullocks that he had knocked over a few days before near their temple on the flat where the cattle grazed. Another lot, out on picket to watch, had evidently heard some news or seen the tiger; for they broke out into very bad language, as one could guess by the intonation of their deep hollow voices, some young active bucks racing across a wide open space with astonishing bounds. A langur, when racing, will bound perhaps 30 feet each bound, or 40 when he tries, partly on hands and feet, but mostly springing from the hind-legs. Swinging themselves into the branches of the nearest trees, they kept shouting as plain as could be, 'The tiger! the tiger! Keep clear of our grounds.'

There was no doubt he was not far off, prowling with slow stride, enjoying his morning's stroll and thinking of retiring for the day. Perhaps he will cross by my ghat. This was about 5 a.m., before the gualas were astir to drive out their cattle in the valley. Several times there came little kakur, or barking deer, ${ }^{*}$ grazing not far off, a pretty little orange-coloured deer, which barks often in the mornings and evenings like the single bark of a small dog. All animals were safe from my rifle, however, save

* Cervulus aureus-the rib-faced or barking-deer, according to Jerdon. Almost identical with the muntjac of China. It is very agile in creeping among thickets. It is somewhat like the roe-deer of Europe, but much smaller. 
the tiger, a cruel and wasteful brute, which did much damage to the poor villagers' cattle. He was killed shortly after in a trap set by the villagers. It consisted of huge beams with rocks on top, propped up with a forked prop and trigger, under which a kid was tied, not far from this very ghat.

It is wonderful how the jungles at the foot of the hills teem with bird life. Some are permanent residents, others are migratory, on passage in the spring to northern latitudes across the snowy range. They include nearly all the small birds of Europe which migrate, besides hundreds of Asiatic types. For instance, our own familiar skylark visits India in the winter, and breeds, probably, on the plains of Tibet; but (according to the ornithologists) there are nineteen other different species of larks found in India at one or other season. Then there are all the migrants which do not cross the snows, but remain in the cooler climate of the Upper Himalayas all through the summer, returning to the plains in the winter.

The permanent residents are also numerous. In a morning's beat at the foot of the hills, following the flat valley between densely wooded spurs where a stream flows, we come, at early dawn, first on a troop of pea-fowl, the gorgeous long-tailed cocks sunning themselves by the water, the young birds and sleek brown hens picking about among the senna bushes. They hear us coming and run to a thicket; but a brace of red spaniels, taking them before and behind suddenly, flush half a dozen, which fly with rapid wing-stroke in all directions, some coming to the two guns, which knock over a couple. The young birds were much sought after at Christmas-time by lady housekeepers as substitutes for turkey.

Then we beat through the low scrub in the old bed of the stream, now dry, where the dogs flush a few black 
partridge,* which come to bag. Hark! there is the cackle of a jungle fowl, like a little game hen. $\dagger$ The flock, including a gay red-hackled jungle cock, are running through the covert for the hill. They are flushed by the dogs, and fly past one gun. One little brown hen flies into the branches of a khair (acacia) tree, and sits there in a confiding manner, peering down at the dogs smelling about exactly under her, with her little head on one side, looking exactly like a familiar barn-door hen or miniature Dorking. No one could have the heart to disturb her, and we pass on seeking other game. The jungle usually resounds every morning with the 'cock's shrill clarion.' It is shrill indeed-a short call of four syllables, kb̆-räyeallee - and reminds one of the farm-yard, but is less drawn out. This fowl seems to be exactly our domestic fowl, and probably the parent of all modern breeds of poultry. There is another species in Madras.

Following the broad flats where camel-thorn trees grow and many thorn bushes, we come out on the open plain, where villagers are busy cutting the ripe barley, the women with sickles and the men tying sheaves. We engage a few boys to beat the stubbles for quail, which at this season move north, just following the harvest. These plump little birds spring in twos and threes with a sudden and disconcerting bustle, and fly straight away, not four feet from the ground. It is most provoking that, just as the gun is levelled and sight taken, a black, half-naked reaper lifts up his head from his harvesting exactly in the line of the quail. One gets off well if, after having shot ten brace of quail, the bag does not also include a native, who has to be paid at the rate of perhaps five rupees per grain of No. 9 shot. Returning towards the hills, we beat the

\footnotetext{
* Francolinus vulgaris (Kala titar).

† Gallus ferrugineus (Jangli murghi).
} 
slopes across the stream, which has sunk into the gravelly soil and left its bed a channel of dry stones. The spaniels put up a few plains partridge* at the edge of a circular threshing-floor, where the natives are busy driving oxen round on the corn, laid on the smooth, hard floor in true Biblical pattern. Other natives are winnowing, simply dropping the barley on the heap from a sieve, while the wind of the 'Rani's fan' carries away the light chaff. The dogs are busy amongst some rocks where wild thistles grow, and put up a bevy of button quails, $\dagger$ which buzz up in a great hurry in different directions, fanning out as they fly. These are much smaller than the ordinary quail, and are very plump, round little birds, but hard to knock over, as they often seem to fly through the shot in safety. Going higher up the hill and on to flats rising in steps, we meet more black partridge and pea-fowl, and work up the valley, where many low-growing shrubs give shelter for pheasants to roost and pick under their stems. A flock of kalij pheasants have been drinking at the stream, and the dogs follow their scent. Soon we hear the squeak, squeak, or piping call peculiar to these pretty silver-necked birds, as they are flushed and scatter, giving a shot or two and fluttering into the trees. The hens are quiet, brown-plumaged birds with short tails, and do not fly freely, but are fat and undeniably good eating. There is also the peura partridge, which lives in the thicket and is almost impossible to get a shot at. Its call is a very soft low whistle, repeated about ten times, quicker and higher each note.

No one can fail to notice the beautiful Paradise flycatcher,§ flitting from tree to tree in small troops, the

* Francolinus Pondicherianus (titar).

+ Turnix Tancki.

$\ddagger$ Gennaus albocristatus.

$\S$ Terpsichore paradisi, according to Blanford. 
two long white feathers of the tail, I2 inches long, fluttering in the breeze. The bird without the tail measures about 4 inches. The black-and-white body and crested head of the mature male are contrasted with the brightred colour of the younger birds. The deep-blue-coloured rock thrush* with yellow legs, which inhabits the thickets, reminds one of the familiar blackbird. The golden oriole's $f$ soft, sweet whistle sounds all day among the tree-tops, a single mellow note. The red-billed blue magpies f flutter among the bush thickets, screeching as they follow one another in a string. The Himalayan jay§ is a lively, gay-plumaged bird. Then there is a very remarkable black bird seen mostly in pairs, with two long tail-feathers, all bare shank with two round plumes at the ends about the size of a shilling. This is the lesser racket-tailed drongo, $\|$ a very beautiful bird. Brilliant in scarlet plumage is the Indian minivet, $\Phi$ with its bright orange mate. Then, on the flats below the hills, there are swarms of noisy, chattering mynahs** picking in great flocks busily all day, like starlings, a bird so tame that he scarcely moves out of one's way, getting a good look at the intruder, with his quaint head, which has a bald patch on it, turned to one side. There are twenty-five different species of mynahs described by Blanford, so there are plenty to keep the insects picked off the fields. The bulbul, $\dagger \dagger$ of classical reputation as the sweetest songster in India, the nightingale of Lalla Rookh, is a disappointing bird, singing but a very common twitter. $\mathrm{He}$ is a dark, dull bird, observable only from the crimson patch under his tail; but there are about thirty species

\footnotetext{
* Petrophila solituria.

+ Cissa Chinensis.

II Bhringa remifer.

** Acridotheres tristis.
}

$\dagger$ Oriolus kundoo.

$§$ Garrulus bispecularis.

- Pericrocotus speciosus.

$\uparrow \dagger$ Malpastes intermedius. 
of bulbuls, so it is hard to know the habits or song of many of them. The little weaver bird* is a charmingly confiding bird, like a sparrow. They come every year to the same bush, a colony of five or six pairs, and build their beautifully-shaped hanging nests, like bottle gourds with a narrow neck, all neatly woven out of dry grass, and all quite low down near the ground; and bring out their young unmolested by man. The boys in India, though possessing some habits not very commendable, do not appear to rob birds' nests. When crossing the open, uncultivated flats, the very loud and plaintive cry of the spur-winged plover $\dagger$ never fails to attract attention. 'Pity to do it! pity to do it!' he shrieks, flying and curling in hurried alarm round and round. He carries a strong, sharp spur bent sideways at the shoulder of his wing. One day, when riding on an elephant, I discovered how useful the spur was. I saw one of these birds engaged in mortal combat with a snake which was trying to rob her nest, a perfectly bare spot on the bare ground. The bird got the best of the battle, inflicting some sharp spur blows on the serpent, which retired discomfited.

Talking of snakes, there are great pythons in the Bhabar, which are said to swallow anything they can get their jaws open wide enough to pass down, up to a young deer, which is first squeezed to death, then flattened and bolted whole. The longest I have seen was I5 feet long and not very thick. Poisonous snakes, on the whole, do not come in evidence before one, and in the course of years going through the forest I have scarcely seen two dozen. I always wore long boots, and at night one did not walk about much without a lanthorn. The munshi's wife died of a cobra bite got at night by walking about in

* Ploceus manyar.

+ Hoploplerus ventralis. 
the dark, and a grass-cutter also got bitten and died. I gave brandy on each occasion, but it was useless. Grass snakes and tree snakes and harmless water snakes are common, but seldom annoy one.

The insects in the forest would take books to describe. Wild bees are the most obnoxious, and if disturbed in their nest will sting a horse, dog, or man to death if they can. Centipedes and scorpions are legion. But the most beautiful of insects is the giant spider, bottle-green and golden, which measures 6 inches across, counting his numerous legs. He makes a web between two tall trees, and sits in the centre of it, his great golden body shining in the sun. When passing through the forest on an elephant I have refrained from going on through a web, not liking to encounter the spider or destroy so beautiful a web. There are too many wonderful and beautiful creatures in the forests to describe the tenth part of them, and the reader must be referred to works of natural history, where they are described scientifically. 


\section{CHAPTER XVII}

\section{THE TERAI : SPORT OF PRINCES}

A WIDE plain, stretching southward and eastward and westward to the distant horizon, lately one sea of tall grass, now blackened and swept bare by the annual jungle fires, except where there remained patches and islands of sedge and reed which had escaped the devastating flames. These are often literally islands, lying between the serpentine and ever-branching courses of sluggish streams, which take their rise in the swamps of the Terai. The shikari elephants, which have plodded their twelve-mile march with stealthy, long, striding step all day through the dense forest of the Bhabar in the intense heat of an April day, emerge into the open plain. Swamps and muddy pools are reached, and the elephants, with pleasant clapping of their great limber trunks and metallic noises, talk to one another; and splash in the stagnant water, squirting it over their hot and shiny sides, which look black and gray and wrinkled, like an old man's hand. Far away to the south, where the patches of long grass follow the course of a slow-winding stream, cut like a canal, but with ever-crumbling banks, through alluvial mud, there appears some rising ground with bushes of khair and sissoo-trees and dhak, all gorgeous with firecoloured blossom, and a few lofty semal-trees, and belts of bright-green jamun, like willow, growing in the hollow 
places. Under these trees can be seen a double row of white tents with a large oblong marquee in the centre, surrounded by lines of picketed elephants, horses, and camels, and the usual crowd of native servants bustling about, and fires burning, where cooks are busy, sitting on their haunches, and bheesties bringing their wellfilled masaks of clear water from the well.

The place was called Uncha Ganw, or 'lofty village,' but there was no village visible, only a few chappars or grass huts, where gualas herded their buffaloes; and uncha did not signify more than an elevation of a few feet of dry soil above the dead level of the swamp.

The elephants were made to kneel down at the doors of the tents, and each sahib dismounted, willing servants handing in guns and small articles. The sun was now setting, and the blazing sky had become suffused with the opalescent tints of dusk, reddening to a hazy deep crimson near the western horizon, to be followed by rapid nightfall. It was a real pleasure to wash off the dust of travel under the flow of the bheesty's masak inside the khanats of the wide tent. The bearer was particular to have every article of evening attire laid out, and the studs ready, in a shirt got up as well as if it were done by a Parisian blanchisseuse. The gong having sounded, the guests assembled in the verandah of the large tent, where chairs were set on a thick carpet, while inside could be seen through the chinks a long dinner-table glistening with glass and silver and shiny linen. The head khansamah, a portly person with curly black hair and beard well turned up, and spotless white dress and flat turban, bearing the crest of the noble house of Dalhousie, announced with stately dignity that the Hazur's soup was on the table. The head of the table was occupied by our most genial host, Colonel the Hon. Henry Ramsay, C.B. 
The party consisted of the Commissioners of Bareilly and Terai, a Brigadier, a Colonel, the Magistrate of the Terai, a man to be trusted to organize a beat under the Chief's instructions, the Forest Surveyor, and a Rajah. The latter, of course, dined in his own tent. The table was brightly lighted by numerous candles, in glass shades to keep off wind and insects; and lamps swung to the ridge pole. The floor was well carpeted, and the moisture from the ground below was completely excluded. The deadly cold damp chill which comes on at nightfall in the Terai, after the burning heat of the day, was not so marked after April I; but in the early cold weather it is bad for giving fever. At this season the climate was delightfully cool at night, and the surface so well dried and baked by the sun that little chill was felt, and nothing could be more healthy. This was camping in luxury indeed, and could be carried out in no country better than in India. Everything had to be packed up at night and carried on to the next camp, a second lot of tents being sent on and pitched ready for the next day. The organization was excellent, and all done without noise or mistake in regular routine.

At first dawn of day shikaris were at the door of the Commissioner's tent. Kia khabar hai- 'what news of the night ?' A few shivering gualas in black blankets were crouching by a fire. They had tracked a tiger into a nullah late last night, and another reported a kill of two cows in a certain swampy place. It was yet dark, but for some time the little jungle cocks had been crowing in the dense brushwood all round the camp, their shrill voices ushering in the early day. There is no time so beautiful as the dawn in the Terai. A heavy dew covers all the herbage, and the bushes are whitened with sheets of dew-spangled cobwebs. The air is perfectly still, and Nature seems to wake up slowly, as if with difficulty 
roused from deep sleep. The eager sportsmen, however, do not take long to get into their khaki hunting jackets, and take at their tent doors the refreshing hot tea and toast. The elephants are ready. Howdahs are strapped on tightly, each girth being tightened by a ratchet windlass with iron chains, besides the rope girthing round the pad. A howdah coming loose or getting displaced in a scrimmage with tigers might be serious. But in the camp of Colonel Ramsay, who had slain his 'century' of tigers, such things are properly seen to ; the elephants are staunch to the backbone, and the mahouts and men require no instructions. The bara sahib rides a splendid tusker called Ram Bux. He was a notorious fighting tusker, and would, if so instructed by a word from his mahout and a gentle kick behind the ear from his bare toes, by which he was guided to right or left, rush in on a wounded tiger, and impale him on his pointed tusks and kneel on him to the death. Otherwise he stood as steady as a rock when a tiger charged, and gave his master a steady shot. The shots from the Colonel's favourite double Sam Smith rifles, with I4-bore round bullets, were delivered with such coolness and accuracy that in many encounters during a series of years Ram Bux had never once been wounded; so that mahout and elephant had perfect confidence in their master, and never flinched from the most furious charge of a roaring tiger, enough to terrify some elephants and make them turn sharp round and bolt. When this happens, the result may be an unsteady shot, and that the tiger lands straight on the tail of the elephant, which gets gashed by the sharp claws of the infuriated brute, and the elephant becomes unmanageable and always unsteady ever after. Colonel Ramsay used to say that he would not lend his staunchest shiliari elephants to a bad shot, as it is the bad shot who spoils the elephant. 
It is absolutely forbidden by the laws of howdah shooting to fire when a tiger is on an elephant, as ten to one the elephant would receive the bullet. Luckily a tiger, from the great weight of his body, cannot spring off the ground as a leopard can, or an ordinary cat, which latter can spring ten or twelve times his own length from the ground, and with ease ascend to the tops of trees. The tiger can only ascend as far as he can reach with his forepaws, and has scarcely ever been known to make good his spring on to the top of a pad. I have seen the eight marks of the tiger's claws on the top of my elephant's head, but that was exceptionally high for one to spring. The mahout's knees are quite safe under the elephant's ears, and the howdah is well above the highest claw mark. An elephant always curls up his trunk, which is his most sensitive organ, close under his mouth when a tiger charges, and so protects himself. It is very important in beating out the long grass for all the elephants to be kept exactly in line, and the rule is to fire only forward or straight back, but never sideways from the howdah. These cautions are duly given to the uninitiated, and our Chief was very strict about the rules being observed most stringently. The party in this case consisted mostly of old hands, who all kept their places and obeyed the orders received silently and promptly. The success of the drive depends entirely on good management and perfect silence, as otherwise the tiger invariably hears approaching enemies, and will break back in the long grass if the line is not perfect, and give no shot, or slink away if he hears voices before the line gets near. Natives are placed on trees at certain points which the line cannot command, and are ordered if they see the tiger slinking away to tap lightly on the tree-stem, which makes him turn in the required direction. Care must also be taken to 'go 
up wind as much as possible, and to place some howdahs forward as long-stops at the end of the beat, in case of tigers moving off too soon.

All preparations being duly made, the long array of elephants starts for the ground where khabar has been given that three tigers have been tracked to a certain swampy nullah. Including several belonging to the Rajah of Rampur, there are twenty-eight elephants all told-eight howdahs, and twenty beating elephants with pads, on which ride shikaris and village guides and chaparsis, armed only with spears or latties. These men have to hold tight on to the ropes which bind the pads to the elephants' backs. Between each howdah in the line are two or three pad elephants. No word is to be spoken as the long-stops are sent on to their posts. The Rajah is mounted on a very fine elephant, and his howdah is painted and gilded in gorgeous tints, his gaycoloured attire and liveried attendants contrasting with the plain teak and cane-sided howdahs of the more business-like sahibs, and their brown, drab-coloured clothing. Each sahib has his loader in the seat behind him, and his battery of eight or ten barrels handily placed in niches to his right and left, the barrels pointing up and forward. The I6 or I2-bore round bullet, with a fair strength of powder behind, was then used preferably with rifle or smooth bore, but some preferred a conical bullet.

The elephants are soon in position, advancing through the long grass from the south, now spreading out wide apart so as to cover the whole strip, now concentrating more closely as the width of the jungle becomes less, always forging onward towards the point where the tiger would probably break northward.

Symptoms of tiger presently are too plain-the torn and half-eaten carcase of a poor white cow, or the bones 
of an animal, now bare and bleached. An elephant screams sharply, and the others tap the ground with their agile trunks, emitting a metallic sound of warning as they scent the wily foe. See, there is a well-tramped spot in a thorny cane-brake, where a tiger has been lying partly in the water for coolness! A cane-brake is an ugly place to put an elephant through. It is a tangled mass of green, shiny ropes, all twined in loops, every few inches armed with the sharpest and most hooked of 'wait-a-bit' thorns. No elephant will stand thorns, which stick in his great feet and legs. These thorns will penetrate strong leather, and the coils of cane are so long and strong, creeping about for scores of yards, that to get in amongst the tangle is to stay there some time. The tiger has his passages under the brake, and can crouch and slip through any place. Here he lies all the hot day, secure against any intruders. No animal except the grunting boar can penetrate to disturb him. The boar is a sulky brute, and does not fear to have a tussle even with the king of the jungles, the royal tiger, and sometimes gets a good score off him. Our old shikari says that he once came across a dead tiger and a dying boar lying together, the former ripped up to the liver by the sharp edge of the boar's tusks, and covered with bleeding gashes. The boar was mauled all over by claw marks; but his neck is so thick and his vitals so well covered by fat that the tiger's teeth could not penetrate deep enough, and so the tiger finds him a most ugly customer to encounter.

Slowly and carefully the mahouts force the unwilling pad elephants to trample out every thicket, and there is not a lair left unexplored; the line is kept advancing towards the end, which narrows to the head of the covert, and only some hundred yards of thick jungle grass remain 
to be beaten. Here the elephants become intensely excited, and press forward with a peculiar nervous rush, closer and closer together, in a steady phalanx, each howdah with the pads between. As yet no tiger has been seen ; some hog-deer have scampered away, flying through the close grass; and the eager shikaris, standing in the howdahs with rifle in hand, are intently watching the covert beneath them. There are only a few yards left of shorter grass scarcely long enough to conceal a cat. Suddenly, and as if springing from the ground, three large tigers dart with a fearful deep-sounding roar-' hoohoo' -from the last patch. One is bowled over by a gun placed as long-stop; another, struck by several bullets, turns with a lightning-like charge straight on to the head of the nearest pad elephant; the third, a great male tiger, with the air of a monarch who has never been used to have his will disputed, comes on with open mouth, and roars, and dies facing his enemies, struck down by a storm of bullets. The poor pad elephant, trumpeting and shaking his head, dislodges his dangerous enemy, which slinks back into the covert, wounded and infuriated. The line is faced round, and the tiger followed up to some thorny bushes. It is now that the elephants become unsteady, and trumpet and turn round, as each time that they advance to the bushes the tiger comes on with a roar and a bound. Each time, however, his charge is so rapid and the grass so tall that he scarcely gives a chance for a shot before he skulks back again into his friendly shelter. However, at last 'he' succumbs to a well-directed shot, and turns out to be a very fine tigress.

The shooting had been good, no tiger had escaped, and, most important, the bandobast (arrangements) had been carried out to perfection and no mistakes made. Colonel Ramsay would say that, if he gave his whole troop of 
elephants and staff of men to a 'griffin,' or one who did not know the habits of tigers, he would back the tiger to get away without giving a shot or being seen at all. On the return to camp, through an open country of shortish grass, permission to fire at all kinds of game was given, and the whole line of elephants and howdahs beat across the plain. Very pretty practice was made with the rifle at hog-deer, spotted deer, and pigs, which were started frequently, and bounded or ran at a great pace across the front of the line. Many were knocked over at from Ioo to 200 yards with the bullet. Standing in the howdah, the unsteady rolling of the elephant must be counteracted by a swaying motion of the body from the rider's knees, alternate with the step of the animal. The rifle must be thrown forward of the moving mark at the moment of firing, so as to strike the game in a vital part.

As a rule, only deer with horns are fired at, as the slaying of females is not considered sportsmanlike, though, alas ! it is often done by people who should know better. Peacocks also are shot occasionally with the bullet, and also hares. Pigs are never spared, and are easily shot, as they go in a very straight line and run in a deliberate and sulky manner, as often as not coming straight for the elephant with an angry grunt-grunt. Elephants dread a pig more than a tiger, as he runs between their legs and strikes with his tusks, giving fearful gashes with astonishing speed. The shooting at smaller game when there is a chance of a tiger being in the neighbourhood is quite forbidden. One shot might easily render futile all the arrangements for locating and surrounding the tiger, as he will quietly slink off through the long grass, going a long distance to another lair. A fox is said to be the wiliest beast, but he does not come near a tiger, which, being a much larger animal, is less easily 
concealed, and is therefore more cautious from constant necessity. As a rule, the larger the animal the more difficult he is to get a shot at. From being so conspicuous, his eyes and ears and powers of scenting the approach of intruders, especially man, are more highly developed.

Thus, the elephant has larger ears and a nasal apparatus more sensitive than other animals even in proportion to their size ; and his eyes, though small, are very sharp, and he is the hardest to stalk of any known beast unless the utmost caution is taken. The bison and the buffalo are equally wide awake, as anyone will find who tries to get near them. The native shikaris know by instinct how they must track; but without their aid, and without the employment of counter-wiles and forethought to avoid the smallest blunder, very few shots at big animals are obtainable. If one watches the motions of a tiger or leopard, their invariable method is seen to be one of constant avoidance of being seen. They crouch almost to the ground and advance a few steps with velvet tread, making no sound, then stop still like a statue, with eyes and ears straining to detect the smallest movement in the jungle; then, being perfectly satisfied, they glide on a few steps, and stand again to take a fresh observation. Then they always take a cast to leeward in order to get the scent of anything on the ground they wish to traverse.

A man, as a rule, goes simply blundering on through the jungle, making every imaginable noise with his boots and voice, and breathing as loud as a grampus, regardless of the wind, which gives him no information, and making so much noise as to prevent him hearing what slight sounds the jungle does contain. Natives with bare feet, of course, have an advantage. And an unshod horse being led through the jungle will sometimes put a sambur deer off his guard; but only sometimes, as the difference 
between the sound of a man walking and a four-footed beast is as easy for a jungle beast to detect as if he saw them. But the gliding, silent step of an elephant, when heard by game, seems to cause them no alarm. They know that elephants are harmless, quiet beasts, minding their own business and hurting no other animal; and, in fact, the wiliest beast, spotted deer, sambur, or buffalo, will simply stand and stare at a passing elephant, or go on quietly grazing. Hence the advantage of shooting off an elephant. Until the shot is fired, and the poor, unsuspicious beast's attention is attracted to the men on the elephant's back, which at first, apparently, they do not notice, they do not even run away. This is the case certainly in the Terai and Bhabar forests, where wild elephants exist, and are known by all other animals to belong to the jungle fraternity. How often a poor beast can be thus shamefully deceived I do not know; but I imagine only once, if he does escape the eight barrels which the howdah contains. Yet it requires much practice to hit even a standing deer from the moving howdah, and it is wonderful how many are clean missed.

One morning after breakfast, on an off day, the smokers of after-breakfast cheroots strolled from the tents to where a chamar was engaged skinning a very huge male tiger. He was duly measured before skinning, and taped Io feet 6 inches, being a very heavy tiger, with immense head, well fringed on the cheeks like a Persian cat. His tail was short for the length and size of his body, and the weight and size of his great muscular paws and forearms gave one a fearful impression of what short work such a monster could make of a man, if one were so foolish as to put himself on a par with so powerful a beast in mortal combat. Having seen the fine skin taken off and properly stretched on the ground with sharp bamboo pegs, the 
fat adhering to the skin being scraped off and wood ashes applied, Colonel Ramsay ordered the carcase to be dragged out from under the thick mango-trees into the open. Taking out his watch, he asked us to make a guess as to how long the vultures would take to clean the flesh off the bones. Some said half an hour. As there was not a vulture in sight, this seemed even betting, but Colonel Ramsay gave them ten minutes, which proved to be correct. There was one vulture at first seen soaring round and round very high up in the cloudless sky. He closed his wings, and dropped on to the carcase with a swoop. In two minutes the sky was full of vultures, all concentrating from every side on the spot, and arriving, with all the impetus their drop from a great height gave them, as fast as it takes to tell the story. Then there commenced a frightful scene of literal carnage, every one tearing with sharp hooked bill at the entrails first, then at the flesh-all fighting for room to get a piece and tumbling over one another with frantic haste, a mass of flapping brown wings and bloody heads and claws, which was ridiculous and horrible to see. When each was gorged, he would sit in a helpless manner round the outskirts of the mêlée, and a fresh lot would arrive to scrape the bones or screech with disappointed rage.

Colonel Ramsay spoke of the folly of attacking a tiger in the jungle on foot. By good luck a man might escape several times, but he was bound to be taken in the end. It was rank foolhardiness and bad shikar. It was also silly to get off one's elephant and jump on an apparently dead tiger, without great caution. This had been done by Lieutenant S., who had struck his tiger with a bullet in the head, and was immensely elated at the ease with which he had finished his enemy. But, alas! the tiger was only stunned, and, jumping up again, took a nip out 
of Lieutenant S.'s side, exposing the liver to view, and tapped him gently on the head, fracturing his skull, and then walked quietly away. I was once told by a native herdsman that a tiger had just killed his cow and carried it away in his mouth, as a cat does a rat. He showed me the tracks of where the tiger had jumped on the cow, and the blood on the bushes; and pointed to a deep ravine, 8 to ro feet wide, with straight banks, over which the tiger had bounded, cow and all. I examined the tracks, and found where he had sprung off and landed, a pretty clean jump. Going on about roo yards, we found the cow lying half eaten. The cow was, to my astonishment, a very fair-sized one. This story I repeated to the Chief, who perfectly corroborated the case, having seen the same thing often. It seems inconsistent with the fact that a tiger does not jump bodily on to an elephant, which is lucky for the shikari; but this might be explained by a surmise that the tiger does not realize that he has a man on the elephant's back to contend with. It is the elephant only he takes into account, and he would be no further in the fight on the elephant's back. He could not by his weight bring the huge animal down, as he does the frightened cow. He goes rather for his trunk, or tries to maul his fleshy limbs, in which he sometimes succeeds, and so terrifies the elephant that it flies frantically through the jungle, and will not again come near or face a feline on any terms. Such elephants are spoilt for purposes of shikar, and are very dangerous to ride on. Many are the well-known stories of ambitious shikaris, who have borrowed elephants said to be staunch, but which, when by evil luck a tiger was encountered, have bolted screeching, tail in the air, crashing through the forest regardless of all obstacles, creating a panic among other innocent hatis, and smashing the howdah against over- 
hanging branches, or perhaps tearing it off and precipitating the bold shikari, with his loaded guns, to the ground, on the top, perchance, of the infuriated tiger. Such are the dangers of the pursuit of tigers with untried elephants, far worse from the animal ridden than the one pursued.

It is unnecessary to describe the rest of the doings of the Terai party, except to say that on this occasion the bag came, in three camps, to nine tigers, and only one that was put up got away unshot. The preference as to position, if there was any, was given to each member of the party in turn. There were few bad shots made, and when the party separated, each lot going their own direction, the regrets were great. Every gun in all the howdahs was emptied in the air as a parting salute, and all agreed that they never had had a more delightful time or a more successful week's shikar party.

Our Chief was a most successful administrator of his province during a period the longest on record. He could not tear himself from his much-loved people of Kumaon, or the country he had won from barbarism; and when he retired it was to live his last days in his beautiful residence at Binsar, in the dear old Himalayan hills.

To describe all the birds and animals of the Terai would be a work in itself. In a game point of view, I may mention the greater and lesser florikin, than which there are no more beautiful birds or more worthy of the sportsman's pursuit. The former is found in short grass near swamps, where black partridges also abound, and these are often shot with a line of guns and beaters, in the cold season, on foot. The florikin rises straight up and flutters like a woodcock. He is a large bird of the bustard tribe, heavier than a wild duck, and is described by Blanford as Sypheotis Bengalensis, 26 inches long; the smaller as Sypheotis aurita, I 8 inches. 


\section{CHAPTER XVIII}

FORESTS OF GORAKHPUR AND NEPAL TERAI

IN the cold season of 1865 I was deputed by the Government of the North-West Provinces, to make a Forest Survey of the jungles of Gorakhpur, bordering on the Nepal territory.

My orders as Forest Surveyor were to map out the forests of that district, which had been hitherto not much known as timber-producing woodlands. The extensive sal forests had been looked upon by the civil authorities as of little value and almost exhausted; and, indeed, the object of Government had been rather to permit the trees to be cut down and the land reclaimed for cultivation, so as to increase the land revenue. Large blocks had been given as grants to natives, who had worked out the fine timber, and then left the forests still uncleared and more worthless than before.

The records and revenue maps of the jungle lands lying along the northern boundaries of the Gorakhpur district and frontiers of Nepal showed that there was a considerable extent of swampy Terai land, covered with long grass, interspersed with stretches of forest reaching southward along the banks of winding streams which flowed into the river Gandak, a considerable affluent of the Ganges. The forests were to be guarded from further depredation, and mapped out into blocks and reserves. 
The work was soon commenced of carefully surveying the whole extent, marking the boundaries of the various reserves, following the courses of streams, and ascertaining the character and quantity of the timber growing. To traverse the jungle elephants were necessary; and the camp was moved daily, and pitched in open glades and elevated situations where found.

The native official in whose charge the forests had hitherto been, called the sarbarakhar, accompanied the survey party, and acted as guide and assistant. He was a gentleman of polished manners, plausible, and ready with every information on the subject of his charge, but, unfortunately, its correctness proved to be generally unreliable. He did not quite enter into the spirit of forest conservation, and believed that such a scheme was a fanciful innovation, inconsistent with his own emoluments. However, the sahib would find out for himself that the jungles were quite worthless-dangerous, indeed, to enter, from the deadly fevers there prevalent and from wild animals. Tigers, leopards, and bears were wont to commit depredations, springing on men and beasts; and were there not great herds of wild buffaloes concealed in the long grass, whose ponderous size and huge spreading horns rendered them impossible to resist when they charged down on unwary travellers? He had terrible tales to tell of these savage monsters, called arna bhainsa; but he had never seen any, and God forbid that he ever should. We started for the jungles, leaving civilization and the bazaar, with forebodings of evil.

My first experience of the Gorakhpur camping was not an agreeable one. The cold weather climate seemed perfection-bright sun by day and a cool, still air at night, when the sun went down in a golden glow with crimson glory. The bright, clear atmosphere became cold and 
almost frosty. The country looked beautiful and parklike, dotted with great spreading pipal and mahua trees, and there were frequent groves of mango-trees near the villages, planted in rows, and called am ka bagicha; the name 'mango tope' is not known to the natives. There was much cultivation, the crops of wheat and barley already covering the ground looked splendidly luxuriant ; flax was already in flower-bright blue; dhal, bajra, and other kinds of millet grew tall, and the whole country looked smiling and prosperous. A square tent with verandah all round was pitched under some spreading mangoes. The smooth ground was dry and hard. The elephants, camels, and horses were picketed not far off, and the natives were busy cooking their mid-day meals of rice or chapatis on little fires of dried cow-dung. The day was hot and sultry, and the sun blazed down most powerfully from a cloudless but peculiar gray-blue sky. The shade of the thick-foliaged trees was quite dark on the ground, but mottled by streaks of sunlight glancing through the leaves. The soft whistle of the golden oriole and the green coppersmith bird in the branches overhead, and the monotonous cooing of ringdoves and green pigeons, betrayed their presence, though their brightcoloured forms could not be seen in the shady thick boughs. Numbers of inquisitive pink-faced monkeys peeped down at the tents below and threw down sticks, but were not inclined to much exercise in such oppressive heat. Little 'devils,' or whirlwinds, causing the dust to rise in pillars, occasionally disturbed the sleepy quietness of the time of siesta, and walked across the plain, taking up dry leaves and scattering them again with sticks and straws.

About three in the afternoon an ominous soughing of the heated air came up at times from the north-west. 
Great lumps of towering clouds appeared on the horizon, changing to dark gray underneath, with an orange, lurid glare. Mysterious rumblings seemed to pervade the air, or come upwards from the ground. Symptoms of an approaching tornado were unmistakable. The natives hurriedly completed their repast and gathered up all loose articles; the khalasis tightened the tent-pegs and loosened the guy-ropes sufficiently to prevent the pegs being torn up by the wetted tent, and deeper trenches were dug round the tents. Presently the roar of distant thunder sounded aloft, and came ever louder on the ear. A great wall of inky blackness rose up in the north-west and approached nearer every moment, though still there was not a breath of air stirring among the tree-tops. Onwards and ever closer marched black darkness, threatening to overwhelm whatever came in its course. The roar, as of a fierce battle, getting louder every moment, the animals became terrified and burst their heel-ropes, some flying before the storm, and others cowering in abject fear. And no wonder, for with a hissing sound the wind began to rise, and, with incessant lightning and fearful peals of rattling thunder, the storm burst over our devoted camp. The trees were twisted round, and the branches torn off and sent flying across the plain. The hail came down as big as pigeons' eggs, with a deluge reminding one of Niagara. In two minutes every movable was sent flying into space. The tents withstood the violence of the first gust, but the second levelled them flat. Men struggled with the tent-ropes to retain the flapping canvas from taking its summary departure, and clung frantically to the great buttressed stems of some sturdier mangoes. The darkness was complete, but the lightning came through it in blinding flashes, at the rate of forty or fifty per minute, and the roar of the wind and hail and thunder was in- 
distinguishable to the ear, deafened by the combined and terrific racket. The hail soon flattened everything into the ground, every green herb and every leaf disappearing under heaps of hailstones; and presently the ground became a lake of water, running away towards the natural outlets in big rivers. Luckily it never rose more than a foot where the camp was pitched, and soon ran away to hollower places. The extreme force of the tornado lasted about a quarter of an hour only; and it then rapidly subsided, the black wall moving away as it came, but leaving desolation behind it.

Many villagers came shivering to help to re-erect the soaked tent and cut passages for the water. They complained that all their crops had been destroyed, their cattle killed or lost, and the houses flattened. The night was fine, not a trace in the sky of the storm, and the stars shone brilliantly. Next day we marched on, and ascertained that the width of the track made across the country was only half a mile. It pursued a straight course southeastward, and outside its area the corn was standing all right, and only slightly laid in places. Along the line of destruction everything was flattened and not a vestige of green to be seen, the ground being nothing but yellow slime and cut up by water-courses. The zamindars were not long in bringing their case before the Collector sahib, and the paternal Government came rapidly to the front with material assistance to the ruined agriculturists, and remitted also all rent and taxes. There is usually a period of winter rain at this season, when the wheat and barley and flax are sown, very necessary for watering the parched ground and to sustain life in the kharif or winter crop. It is often, however, very scanty, and not continued like the barsat or summer rainy season, which comes when the rabi or summer crops are sown. 
The forest trees are not frequently thrown down, though their branches are wrenched off. No trees like English elms, whose roots do not penetrate right down into the ground, could exist at all in India. The fig-trees, like the pipal, banian, paker, and harrar, are principally made up of air-roots, which cling together and anchor the tree to the ground, taking hold of the soil like guy-ropes and clasping other trees, and they are safe against these storms. The mango and mahua, which are planted all over India for their fruit, seem to stand any storms; as their stems are not of great height, and their roots, like gnarled oaks, grow well down into the alluvial soil. The semal or cotton tree (Bombax hcptaphyllum), well known in most tropical countries for its scarlet flowers and cotton-bearing seed capsules and its enormous height, is secured by nature from storms by its habit of growing great buttresses round its stem, which prop it up like those of a lofty cathedral. The sal and teak trees, found in the best timber forests, are capable of standing the effect of storms from their habit of growing together and protecting one another, and from their possessing very deep roots and strong stems, well proportioned and not overloaded with leafy boughs. The saj (Terminalia tomentosa) is another conspicuous and handsome tree of the same character. The survival of the fittest only is well exemplified among these trees. Those only with very thick succulent bark and leathery leaves can stand the scorching of the jungle fires; and the deep penetration of the roots is essential to draw moisture from the earth, some 20 feet below the surface, during the prolonged droughts of the dry season. There is one deep-rooted species of elm common, the Celtis austraica. It reverses the season of casting its leaves, which wither and fall off in the hot weather, and flowers in the early months of the cold season. 
Most of the forest trees are evergreen, so-called, but in truth they are deciduous, casting the entire crop of leaves and bursting into fresh, tender foliage every winter. The fig-trees are remarkable examples of this transformation. I have camped under the dense shade of a spreading pipal, and in three days' time every old leaf was fallen to the ground, dry but still green, pushed off by the budding of the new growth. The delicate, beautiful young leaves had all come out almost in one night, and unfolded to their full size. Unlike the habit of European leaves, which turn colour before falling, the Indian ones often come out bright red and orange and change afterwards to deep green.

In choosing a place for a camp, it is difficult to avoid damaging the crops of peppers, which the natives cultivate much in mango groves. The small-leaved variety here grown produces the celebrated Nipali mirch, whose small yellow pods are of much more delicate flavour than the large red kinds.

I must now bring the reader to the Sunari forest on the Nepal frontier. A sluggish stream with high mud banks, winding in endless coils at the edge of a wide plain. To the west a belt of forest of great extent, consisting of dense growths of sal timber, over 400 to the acre, interspersed with many other usual kinds of trees, the stems, which were not more than 8 inches thick, standing so close together that an elephant could with difficulty force his way between. On an open space by the river, camp was pitched. The rain, which had been falling steadily for two days in a light, drizzling manner, reminded one rather of Ireland. March I had come in, certainly not like a lion, but in a manner unexpected and most unpleasant, the temperature being cold and everything damp and wet, though the ground was 
hard and baked by five months' fierce sun. The tent was luckily dry under the outer fly, but the natives were in miserable plight, shivering with cold, and huddled under chappars of long grass, got from the village on the plain. Many were attacked by fever, and quinine had to be distributed. I sat in my tent working at maps, and realized how much the world is indebted to the sun, and vowed never to grumble at the heat of his glorious rays. Cloud and mist hung over everything, and the jungle seemed a place of dank, impenetrable gloom. The beasts of the forest came to drink in the stream as if the day were dark night; tigers' and bears' tracks were fresh in the mud, and great tracks which I had never seen, as huge almost as an elephant's, but cloven. There could be no mistaking these great wide footmarks for those of ordinary cattle. They were the tracks of the great wild buffalo, the arna, of which I had heard so much, an animal most rare to find still at large in the jungles, the largest and most dangerous of wild beasts, next to the horned rhinoceros.

Next morning the sky had cleared; a bright sun shone out, and all nature was transformed. The dreadful forest was shining and gay, the leaves sparkling with drops of moisture in the glistening rays. Occasional glimpses through the trees of the Himalayas, towering against the northern sky, were visible like a scene in a theatre. The elephants kneel down, and we climb up and start to explore.

The straight black stems of the sal-trees are clasped round by coils of huge creepers, which hang in festoons from tree to tree. One carries a kukri, or Nepali knife, in the howdah to cut these creepers, which would otherwise stop one's progress. An elephant often pulls them down with his trunk at command of his driver, and some- 
times has to go at the stem of an inconvenient sapling with his head and butt it down, shoving it over and then walking on it. This forest had had all the good timber long since cut out of it by contractors, to whom it had been let by Government to clear and make what they could.

The present growth of young seedlings and shoots from the old stools was the result of only a few years' letting alone, so quickly is the vegetation renewed in a climate like a hothouse, with a deep alluvial soil. Northward over the Nepal frontier the old timber has not been cut, and the great straight stems of magnificent trees, roo feet high and 6 feet in girth, are a sight to rejoice the heart of a forester. The system since inaugurated of thinning out the rubbish and small crooked and stunted poles, which the native farmers had a demand for, and leaving the healthy seedlings to grow, has worked well; and the Gorakhpur forest division is now one of the best paying divisions in the North-West Provinces.

Mounted on an elephant, in a comfortable howdah, with maps and compass and lunch and a bottle of cold tea, and a native guide on a pad elephant, we spend the entire day forcing our way through the jungle, at times gliding noiselessly through open glades where there is grass almost 3 feet high, the haunt of pigs and spotted and hog deer (chital and para), while at times we cross, or follow the course of, sunken ravines cut out of the deep alluvial and sandy soil by streams from the hills northward. These ravines are arched over by great branches of weird old trees, jamun and saj and fig trees, whose roots make fanciful interlacings. Creepers hang from tree to tree; troops of langur monkeys with hideous black faces and white, long hair follow one another across the ravine, bounding and swinging from rope to rope. It is difficult for an elephant to cross such ravines. He first tries the 
edge of the cut-away bank with his trunk, then kneels down on his hind-legs. He has a useful joint corresponding to the knee of a man, kneeling on which he slips his trunk and fore-legs over the edge, and feels till he gets some foothold below on the sloping bank. Then he goes down, carefully adjusting his feet, crumbling the bank away, and lowering himself in a flabby manner to the bottom. He appears to keep his head and to face almost any obstacle, and preserves his balance wonderfully. Having crossed the stream, testing the sandy bottom with his trunk to avoid quicksand, he again faces the rising bank, and, climbing up the most likely slope, he puts up first one foot, then the other ; then, kneeling on his foreknees, he pulls up the hind, kneeling on each leg before rising, in a deliberate, slow manner, which soon inspires confidence on the rider's part. The howdah certainly takes appalling angles, and one feels balanced over a precipice; but after negotiating half a dozen such ravines safely, and being assured by the mahout of the perfect excellence of his elephant, one ceases to tremble. A veritable bog, phasan, is the most dangerous thing an elephant can face. When one fore-leg goes down into a treacherous swamp or quicksand, and the other follows from the fierce tussle to pull the great unwieldy leg out, then poor hati gets into a fearful state, struggling madly and groaning, dragging at each leg alternately and rolling from side to side, till all four legs get stuck. Then, if he meets no firmer ground in front, ensues a battle sad to look at. He becomes terrified, and will snatch in his trunk anything he can lay hold of to put under his feet, even a man. Branches of trees are thrown to him in quantities. There was one who got into a quicksand at Gorakhpur in the Gumti river, who went down lower every day, till nothing remained but the end of his trunk over the sand, 
still moving and breathing. Every effort to dig him out proved vain.

An elephant is apparently never tired, and maintains a steady rate of progress over all sorts of ground-about five miles an hour. Small elephants can shuffle along much faster than a big one, and are much more comfortable to ride, the motion being less rolling. It is a great comfort, if one wishes to get home rapidly, to quit the howdah and mount a small, smooth-running pad elephant kept for the purpose.

There is no lack of variety in the day's march, which is generally pretty continuous, only interrupted by a midday tiffin under some shady trees and near to clear running water. The line of the Himalayas is always in sight. One can see the snow-white peaks of Dawalagiri and Mount Everest, the highest mountains of the world. In the foreground there are huts of the natives, who herd cattle and cultivate small patches of grain. These huts, in which they remain at night for fear of wild animals, are of strange appearance, being mounted on poles some 20 feet high, with a ladder to ascend. Herds of black tame buffaloes are dotted over the plain. It is easy to distinguish the arna, or wild buffalo, from the tame, as the former are double the size, and their horns are pointed straight out, with an upturned curve like a crescent moon. Those of the tame buffalo are much smaller, and are pointed from the apex of the skull backwards and down, before curving up at the side of the neck.

The arna is very different from most wild animals, which naturally hide as much as possible from man. He does not fear men, and will remain grazing within a few hundred yards of a man, and if interfered with will move off in a slow and sulky manner, or, if his animosity is roused, he will come straight on and charge and crush to 
death man or beast with great ease and pleasure. The natives dread them much, and keep at a respectful distance, and climb up into trees at the shortest notice. My first introduction to buffaloes was when camped at Sunari. I had returned from surveying. It was just getting dark, and I was bathing and changing my khakicoloured jungle clothing for the warmer evening suit, which was specially padded to keep out the chills of the Terai nightfall, when a chaprasi came breathless to the tent door, saying, 'Arna, arna, sahib!' I rushed out half clad, with a I2-bore rifle loaded with round bullets, and ran in the direction pointed out. I could see the great black forms of five or six big beasts with gigantic upright horns, quietly walking from the plain towards the jungle a short distance off. I ran towards some trees to cut them off, and, hiding behind a big stem, waited their arrival. As they passed about 6o yards off I fired two shots at the biggest bull, which appeared to strike him in the neck or shoulder; but the result was that they only hastened their pace a bit, and lumbered off into the forest, the big brute seeming to care absolutely nothing. The old sarbarakhar was in the greatest excitement and fear lest they should charge our tents. We heard no more about them, and, examining the ground, there were no signs of blood or marks of wounding. The skin of these great beasts is so thick, as I afterwards discovered, that a bullet will not always go through it, and if it strikes a bone it will glance off rather than smash the bone, unless the charge of powder is extra strong. I took to using 7 drachms of black powder instead of 3 , which was the ordinary charge, and substituted a conical bullet for a round in the r2-bore. I tried also a single-barrelled 4-grooved 8-bore rifle, with 8 drachms of powder and a round belted bullet. The kick from these charges was pretty severe. 
I had several views of arna, but on each occasion they were moving across an open place, and reached the dense jungle, where they disappeared. One morning I was camped at Basauli, at the edge of the forest, when a native came to say that a big arna bull, which was 'must,' he said, and very wicked, was committing havoc in his village by knocking down houses and haycocks, and trampling his bit of corn and chasing his tame buffaloes; and he begged me to come at once and slay him. His wife and children and all his brothers were up in trees, and they were afraid to come down. I mounted my good elephant, and, armed with every weapon I possessed, was soon advancing in the direction pointed out. The great brute was standing still in a patch of green corn, and faced away from us. The mahout walked the elephant straight for him, and he did not notice our approach until we got within 200 yards. He then faced suddenly round, and I had a good opportunity of observing his enormous proportions. He was very little like a tame buffalo, as he had none of the angular coarse shapes of the common bhainsa, being round and fat, with straight square back, enormous thick neck, and great fierce head, with a crescent of huge black horns. It was fine to see the sulky glare of his wicked eyes, as he swung round and had one steady look at the beast which dared to dispute his possession of the ground. The size of his adversary seemed to dismay him not in the least, and the insolence of any animal coming to disturb his reflections seemed to enrage him at once. Shaking his huge horns and lashing his tail, he just put down his black head, and, with a peculiar roar, came full gallop straight for the elephant. My steady old hati stood there, preparing to receive the charge on his own broad forehead, but at about 25 yards the bullet from the 8-bore rifle struck the bull fair between the horns. 
I could hear the crash, and the charge was just stopped in time to avoid a collision. My friend had got a smash on his old skull that he didn't expect; for his courage failed, and he turned tail for the jungle, shaking his head and grunting. I gave him a couple of I2-bore bullets in the stern, which hurried his pace; and he disappeared pretty quickly into thick jungle, where I failed to track him through the thicket. Some days afterwards he was found dead by the natives five miles away, and very pleased they were that the country was rid of him. I got his horns, enormously heavy ones.

I frequently got a shot at a lovely buck chital when the herds came out at evening or early morn to graze on the plain, where the young green grass was springing from the old burnt roots. At night the silence of the forest was at times wakened by the loud and sonorous belling of these pretty deer. It seemed a sin to shoot them, but venison was much wanted. Walking silently along the edge of the timber, one might see against the sunset sky the graceful forms of some does feeding, which I would not shoot at. Presently a spotted stag, with his long slender horns thrown up, might be viewed standing in a gap between the brushwood, watching the does and giving a chance of a shot at I30 yards. I had a Jacob rifle, 24-bore, with four grooves and a conical bullet, hollowed in front, which was very true at this range. I could generally put it in behind the shoulder if I got a fair chance, and the bullet, opening, made a deadly wound, so that the poor beast did not get away to linger and die in the jungle, but fell in his tracks, and was made into excellent venison stew or roasted over a bright wood fire. This rifle was one of the first of the small-bore conical projectile weapons, which have now been brought to the height of perfection in the Lec-Metford service rifle. To 
General Jacob, an old Indian officer who fought in most of the campaigns of the first half of the nineteenth century, is due the credit of inventing the conical principle. He also advocated the gaining twist which Metford adopted, and the hardened lead and the perforated point; and for game rifles he used an explosive copper shell, inserted if required in the point; but these, I found, burst too soon, and did not penetrate enough in a big animal.

On Narch 8 I joined camp with the Commissioner's large shikar party, consisting of Mr. Charles Lindsay, Commissioner of Gorakhpur, and Mrs. Lindsay, Mr. O. (the Collector), Captain and Mrs. W., and Major D. (police officer), also the Rajah of Bansi, a wealthy and very sporting native prince. Our camp was pitched at Sukwi, in the maidan, under spreading mango-trees. The large white tents occupied quite an extensive space, and the camp-following, with hackeries, bullocks, horses, and lines of picketed elephants, had a most imposing and picturesque effect. There were sixty elephants all told, some for carrying tents on the march, the rest for beating. The Rajah had a magnificent elephant. He had been purchased by an eccentric old gentleman called Jungli Read, living at Gorakhpur, from Jung Bahadur, who had sold him because he was very wicked. But Read had tamed him by kindness, and sold him recently to the Rajah of Bansi, who wished to possess the finest elephant in India, for Rs. Io,000, equal then to $£ \mathrm{I}, 000$. He was now perfectly gentle and of great beauty; being highly fed, his condition was perfect, and the other elephants looked like babies beside him. The difference between a lean, bony horse and one in fat condition is great, but in elephants condition improves the appearance even more markedly. This great beast was nearly I2 feet high and broad in proportion. His head was well set on, and his 
perfect tusks measured over 9 feet in length, and were snow-white and beautifully curved. The track left by his fore-foot was 6 feet in circumference. He figured afterwards in durbars, covered with gay hangings and bearing a silver howdah. To possess such an elephant is the greatest pride of a Rajah. He was more for show than use as a shikari elephant, being too valuable and heavy to risk in swampy land for fear of getting into quicksand, but he looked well in camp.

Our Commissioner had obtained passes for the party to go into Nepal, where game and tigers were plentiful. We marched next morning north-eastwards across a wide, open maidan, covered with a sea of long grass in the rains, but now nearly bare, the grass having been all burnt, except in patches where the water still lay. The line was an imposing one, the howdahs at equal distances and pad elephants in between. This day, however, the jungle was too open for much game. A very fine tiger cat, nearly as big as a sheep-dog, was shot, a rather rare specimen of the wild felines, called 'kaksa' (Felis biverina).* Black partridge and hares were useful additions to the bag. Mrs. Lindsay hospitably entertained the party in a large tent, ready pitched, on our arrival at Biskope, a jungle village in Nepal. The weather was hot, but the evenings beautiful.

Major D. was our boss shikari, and a capital good fellow. He made dispositions for our next day's advance into the wild and little-known jungles of the Nepal Terai. Tigers and wild elephants were to be met with, and perchance the ugly rhinoceros, besides plenty of smaller game. The morning was bright, and the line of elephants was soon in motion, facing across an open plain straight

* Described by Jerdon as frequenting the Nepal Terai; length 34 inches, tail 12 inches, height 16 inches; a gray tiger-cat, partly spotted and barred, and very destructive and fierce. 
for the foot-hills, now about twelve miles distant. In case of pigs breaking across the plain, as yesterday, Captain W. and I had ordered our horses to be led behind, with hog-spears. They came in useful for a bigger bit of shikar. We had not gone far when we sighted a herd of twelve great black beasts grazing near a stream. With my glasses I saw that they were arna, and that one of them was a very large bull with great black horns. $\mathrm{D}-\mathrm{y}$ believed they were tame buffaloes until we were too near them to put out the line of elephants so as to intercept their flight for a belt of jungle to the east of the maidan. Presently the herd of arna started to gallop towards the jungle, cows first, then some bulls following. The big bull brought up the rear to guard his flock.

$\mathrm{W}-\mathrm{n}$ and $\mathrm{I}$ were eager for a gallop, as the ground was suitable, and, slinging our rifles across our backs, we started on horseback after them as hard as we could go. Being quickest at the start and on a very fast mount-my black Bokhara-I was not long in overhauling the body of the herd, cutting them off as they lumbered heavily across our front, making for the forest. The ground was fair for a clever horse, there being but a few small dry water-courses to cross. The old cows, however, were not what I was after, but the big bull; who, seeing an enemy approaching his family, put on a spurt, with head down and tail in the air, making the dust fly, to protect them, and charged straight at my horse's flank. There was still a quarter-mile of open ground, which enabled me to sheer off to his right, on which he headed again for the herd. This happened twice, and, finding he could not catch me, he had to gallop on to the left of my course, following the herd, snorting with rage and getting decidedly blown. This was my opportunity to dismount suddenly, and, kneeling down, I let him have both barrels 
of the I2-bore low behind his shoulder. The bullets struck true, with a heavy thud. This time I had put in enough powder ( 8 drachms), and one of the bullets was a conical I2-bore weighing nearly 2 ounces. He came on, his eyes flashing fury, straight for his enemy; but it was his last effort-the cruel lead had gone surely home. He swayed from side to side, game to the last, still facing his foe; and, snorting out defiance, he blundered blindly on to his knees and rolled over quite dead. One always feels sorrow at the downfall of a noble wild beast who dies bravely without a groan. His head was a fine trophy, which now adorns my walls with those of many and various animals, but I look on this head of the bull arna as my grandest trophy. The horns measure 8 feet round the curve and $\mathrm{I} 7$ inches in girth. The arna is now, I believe, very scarce. It is sad to see the last of the indigenous cattle swept off the globe by the thoughtless pot-hunter, who shoots females and males alike, and cares nothing that they have as good a title to exist and inhabit the world as man has.* The problem of how the numerous wild animals got there, and whence they came, is one of the most intensely interesting that we can imagine. If men, whose origin is equally mysterious, regard so lightly the reckless slaying of whole species for so-called sport, or, worse still, for the simple lust of slaying or for petty gain, it speaks badly for the boasted evolution of the human species towards a nobler intelligence, a higher knowledge, or a better life.

The line came up, and I received the hearty congratulations of the party, who admired the great bull. He measured 9 feet in girth and II feet from nose to tail, and was I5 hands high; his head weighed 75 sers-I50 pounds,

* The bisons of America and of Europe (aurochs) have been exterminated thus. 
and, being very fat and immensely wide, he must have weighed over 22 hundredweight. A strong little Gurkha chaprasi undertook to cut off the head and bring it in a hackery into camp. Stories are told of Gurkhas cutting off heads of buffaloes with one slice of a kukri. On this occasion it took about thirty strokes of a very sharp kukri to sever the head from the body. He got two chamars to take off the skin, which was immensely thick, an inch and a half at the neck. When pegged out on the ground it was big enough to carpet a dining-room. I gave it to $\mathrm{W}-\mathrm{n}$, who made a boat of it, by stretching it on a wooden frame; and he shot many wild ducks from it in the jhils near Gorakhpur.

The Nepal Terai is a very extensive and typical Indian forest. It contains magnificent timber. There are great stretches of long grass and tangled jungle. Here are the haunts of all kinds of game, and herds of wild elephants live undisturbed in its recesses. Tigers are abundant, and there are but few inhabitants, principally herders of cattle, which are brought for the winter's grazing. Few can remain in the rains, when vegetation is rampant, and the jungle deadly from malaria and impenetrable. Jung Bahadur, the clever Prince of Nepal, lived at Khatmandu (pronounced Khatmaroo). He was very fond of shooting, and kept an immense number of elephants-over 40o. Also he had organized a kheda for catching elephants, in secluded valleys between rocky precipices, where the wild herds were driven in and enclosed. He had well-trained fighting tuskers, and his elephant-catchers were celebrated for their cunning and bravery. But he preserved the policy of permitting no Europeans to travel in his territory or cross the frontier. It was only as a great favour that he issued passes to British officers like the Commissioner of Gorakhpur to 
shoot in his Terai for ten or fifteen days. Our party had an extremely pleasant time, every day beating ravines with long grass, where the native shikaris said there were tigers. We shot bears, leopards, sambur deer, chital, para, and pigs, but our bag of tigers was nil. Jung Bahadur's tigers were too wary for us, or perhaps the shikaris were so instructed. Our party was, in my belief, too large and noisy. We had too many counsellors, and tigers are not to be got except with much jungle craft and knowledge of their passes.

A Terai bear-Ursus labiatus-is a very quaint animal, with a humped back, long shiny black hair, a long snout bare at the end, and long white curved claws. He lives on insects and the eggs of white ants, and roots out the nests with his claws, sucking up the white juicy eggs with his long prehensile lips and tongue. Ants' nests are most abundant over all the Terai. Some places are simply covered with tall pillars of mud, 4, 6, or 8 feet high, and almost anywhere on the grassy plain one can see numbers of these strange pointed erections. They are the same colour as the ground, and often clasp the stump of a dead tree, which has been eaten away and converted into mud, which, after passing through the bodies of the ants, sets hard on drying. There are also red ants of great sizeover half an inch long. These are fighting ants, and if by chance you disturb their nest, which swings, made of leaves stuck together, in the branches of a tree, they will drive you out of the howdah. They have big nippers, and will lay hold of your flesh, giving a painful pinch, but it is not any way poisonous or dangerous.

There are many beautiful birds in the Terai, the jungle teeming with life. There are great flocks of noisy mynahs, like starlings, of three or four species, one, peculiar to Nepal, being a larger bird, black and white, which is often 
kept by the natives tame. It readily learns to talk, and is an amusing pet. There are a great many parrots, of seventeen species. There are deep, silent ponds in the dense forest, surrounded by giant gnarled stems of trees, on the branches of which gray-necked snake-birds, ${ }^{*}$ with long, serpent-like necks, sit ready to pounce into the still water below. Tortoises sit on the bank and sun themselves. There are kingfishers of several sizes, which poise themselves on rapid wing and drop like a stone on the unsuspecting fish, spearing him with their sharp, strong bills.

The whole surface of the pond is covered with wild fowl of many kinds. The beautiful garganey ducks and others sit close together, with white breast and harlequin patches of bright colour. There are little blue teal $\dagger$ flitting in wisps, and whistling tealt, besides all the European sorts. A gun being discharged among them produces enough fowl for a week's eating, and the air is full of clouds of ducks whizzing and circling all round. They migrate northwards to the plateau of Tibet for the breeding season, when the snow melts, and return to southern India in the winter again. To pick them up, one can charter a rickety dug-out canoe made of a long tree, which belongs to the teal-catchers. Most bungalows in Gorakhpur have a teal house, a circular brick building arched over, with a pond in the centre neatly shaped in chunam, where the teal are fattened in absolute darkness for the sahib's table in the hot weather, when meat will not keep. How they are netted is a mystery I could never penetrateprobably it is on the principle of our decoy pipes, though

* Plotus melanogaster, a cormorant-like bird, with a powerful straight-pointed bill, which swims under water after fish, and usually when it comes up protrudes only its head above the surface.

+ Querquedula circia.

$\ddagger$ Nettapus Coromandelianus, whose cry resembles 'Fix bayonets!' 
I never came across any-but there is a well-marked race or caste of fowlers who live entirely by this trade.

In the cold weather of I866 I was acting as DeputyConservator, and spent many months in the Gorakhpur forest, and had ample opportunity of studying the natural history and flora of the Terai, also collecting specimens of all the timbers of the forest, and testing their qualities, and verifying the botany of the locality and the native names.

Sometimes, in the more open country joining the forest, black partridge and quail abounded. The latter were shot on foot in stubble fields with a line of beaters. The black partridge lived in long grass close to cultivation. We sat in the howdahs while the men beat up to us, and got very pretty shooting, as the swift-flying, black-breasted birds came straight up like driven grouse. They are as large as a grouse, fat, and excellent eating. A Rajah had sent the Collector sahib, with whom I had joined camp, two fine elephants to try as howdah elephants. He stated that they were good, steady, shikari hatis. So we started one afternoon to try them, shooting kala titar (black partridge). They seemed a little unsteady when the guns went off, and stamped and made trumpeting noises to one another, but were obedient enough to the mahouts, and we shot a fair number of birds, including a lesser florikin. Towards dusk we were turning towards camp, when a jackal trotted out of a patch of grass. At this a shot was fired. The twilight semi-darkness made the flash visible, and this was too much for the nerves of the already excited elephants. They set off with trunk and tail in the air, screeching with terrified alarm, the mahouts striking the hooks of their ankuses in and shouting 'Dutt, dutt!' very much in vain. We in the howdahs were tossed about, the ground being uneven, and the rapid 
running motion was not agreeable. One felt quite helpless. In the direction of camp was a grove of half-grown mango-trees; through this we crashed. Branches swished by our heads, and we strove to ward off the lighter ones, while heavier boughs were cracked off against the teak frames of the howdahs. Luckily, neither girths nor woodwork, well laced together with canework, gave way, and we arrived in camp, having come a mile in about five and a half minutes. The difficulty then was to stop the elephants or get them to lie down, which they entirely refused to do. However, by bringing up some other steady elephants, which surrounded them, the ladies of the party succeeded in getting safely on to the others' pads, and so were dismounted none the worse for the adventure, which might have been a serious one. We stuck to our own shikari elephants after that. Old Luckmee, a very gentle female, was as steady as a rock. Her old mahout, who put her age at seventy years, was never done singing her praises. 'If she was entirely eaten up by a lion, then,' he declared, 'she would not move. She would let me drive her and obey the words dutt (stop), dutt dutt (lie down), mail (get up), mail mail (go on).' A kick of the toe on the side of the head to right or left she answered as quickly as ever a well-trained charger to the motion of the bridle.

The dear old mahout was as faithful as the elephant, and never defrauded his charge of a chapati more than the legal number, one in twelve, which used to be brought every evening to the tent door and piled in a heap, about Io sers (20 pounds) of flour made into round, flat cakes. There was also an allowance of ghee brought on a large leaf. Each of the chapatis received a smear of the ghee, and old Luckmee appeared to count the number-elevenshe was entitled to. If by any chance one fell short, she 
would express her disapproval by tapping on the ground and trumpeting. Old Koda Bux, the mahout, was very attentive to his charge in the matter of medicine (dawai) for its poor feet, consisting of a bottle of arrack, or, better still, 'brandy sharab' and a small bit of opium got by the sahib's orders in the nearest bazaar. Luckmee's feet often got sore and cracked, and these remedies were quite unfailing in their effect, but not on the hati's feet. Most elephants are good-natured, and will not use their strength to hurt even small children, which are safely left in their charge. A few are really dangerous and spiteful. There was one in our line of pad elephants, which everyone was warned not to go near. He had a very deaf mahout, whom he obeyed. One day, when all the line of elephants had come to a river and were drinking and splashing their sides with deluges of cooling water, the old deaf mahout got down to drink at the water's edge. This 'budmash' elephant began to think it a fine chance to go for a solitary chaprasi who was sitting on his back. Quietly feeling back over the pad with his trunk for the wretched man, who climbed back as far out of its reach as he could get, the brute then gave a vicious shake of his hind quarters to try and dislodge the man, who shouted to the mahout to save him. This went on several times before the deaf man could be made to hear, and he was only just in time to prevent the chaprasi from being seized and trampled to death.

As an instance of the extraordinary instinct of elephants may be mentioned a striking case of their power of finding their way, by tapping or feeling the path with the trunk, and recognising any path they have previously traversed. On one accasion we crossed a very wide river on going out in the morning to beat the jungle at the other side. There was a wide expanse of sand and 
shingle fully a mile across, with shallow water flowing perhaps a quarter of a mile wide. It needed caution to pick our way so as to avoid quicksands and keep on the hard ground, and a very sagacious old elephant was put in front to lead the way. All the others followed in her tracks. We were all day beating through a very extensive jungle of khair, babul, and other trees, and lost our way, so that it was night before we succeeded in getting back to the river and finding the ford. On leaving the tree-covered bank the old elephant was our guide. Before us was a broad waste of sand and glistening water, just visible in the darkness, but absolutely nothing to indicate the direction of our route; yet the old elephant brought us out exactly in the footsteps she had made in the morning.

On one occasion our camp was on the bank of the Gandak river, which issues from the hills to the eastward of the Gorakhpur district, dividing it from Bengal. This is a fine tributary of the Ganges, rising under the peaks of Dawalagiri in Nepal, and one branch of it flowing past Khatmandu. It joins its waters to the Ganges at Patna. The river is about a mile wide when its bed is filled during the rains, but in the cold season it is about a quarter that width, flowing rapidly, and not more than a few feet deep, cutting its way through beds of sand and well-rolled gravel in ever-changing windings. Its cool waters are quite transparent, and there are varied reaches of high banks with trees overhanging, or sandy flats and islands out in the wide stream. These are favourite places for the long-nosed crocodiles, ghariyals or gavials, to bask in the sun. As many as twenty could be counted every morning, lying like great logs of trees about 250 yards from the tents. Being anxious to secure a fine head, we had several shots at them. It needs very careful placing 
of the bullet exactly where the neck joins the body to kill a specimen. If hit anywhere in the body, they simply glide off into the stream and are seen no more. Having watched some time for a very large one, he was successfully plugged with a hardened bullet in the neck, and the spine paralyzed. Elephants were sent out with strong ropes to tug the monster to land, and other elephants hauled him up the steep bank. He measured 22 feet in length, and his skin made a fine piece of leather. The gavial is a very harmless beast and will not attack a man. But the 'muggur' preys upon every live beast he can catch and pull down, and will crunch and swallow in his great maw any animal. In the sluggish deep waters of the tributaries of the Rapti and Gumti near Gorakhpur muggurs chiefly abound. In fact, even close to Gorakhpur there were a great many. A retriever dog fetching wild fowl from the ponds and pools was almost certain to be taken down if swimming in a deep place, and valuable dogs were thus lost. Native children and calves and goats were commonly seized and dragged in, and all dead bodies of Hindus thrown into the river were simply devoured by the muggurs. In cholera times, when the pilgrims are returning from the great annual mela, or fair, and the poor sick people are brought to the water's edge in hundreds, ready to be thrown in when they die, the muggurs have fine times and grow fat.

The regular work consisted in dividing the forest into divisions according to a 'working plan,' the ground to be worked over in a certain number of years. The forest was already full of sal-trees, but many of them had been spoilt by tapping for gum, called ral, and only the worst crooked stems remained after the good trees had been cut. There were, however, plenty of seedlings on the ground, and it was decided first of all to thin out all the bad stems 
which would not grow into good timber, and leave nothing standing but straight young stems. The native demand for the crooked poles, called ballis, was good, as lately all cutting had been prohibited. Thus a considerable income accrued, supplemented by dues for grazing cattle, and the expense of thinning and cutting away creepers, which were choking the young sals, was amply covered. The prevention of fires, so as to allow the seedlings to get ahead, was also instituted with good results.

In the Survey Report the average number of trees per acre is given :

\begin{tabular}{lllr} 
Sal seedlings & - & - & 95 \\
Crooked old trees & - & - & 52 \\
Copse shoots & - & - & III \\
Other varieties & - & & 258 \\
& & - & I 20 \\
\hline
\end{tabular}




\section{APPENDIX TO CHAPTER XVIII}

\section{FOREST PRODUCTS}

The principal useful trees in these forests comprise the following :

I. Sal or Sakoo. Shovea robusta.

2. Saj or Asna. Pentapteva tomentosa.

A very straight, fine tree.

3. Kharma (Haldu). Nauclea cordifera.

A giant forest tree.

4. Semal. Bombax heptaphyllum.

The cotton-tree. Giant columnar stem with great buttresses; light timber.

5. Jamun. Syzigium jambolanum.

6. Mahua. Bassia latifolia.

Very fine, large-leaved, spreading tree of considerable value. The succulent flower is used as fruit.

7. Agai. Conocarpus latifolia.

A remarkable tree with long, pear-shaped leaves 18 inches long.

8. Bhela. Semecarpus anacardium.

The marking-nut-tree. Acrid juice.

9. Khimbi. Careya avborea.

Bark used for gun matches.

ro. Tendu or Abnus. Diospyrus melanoxylon.

Ebony. Heart-wood produces black ebony.

II. Piar. Buchanania latifolia.

Large round leaves; useful timber.

12. Panrar. Lagerstramia parviflora.

Timber used for buggy-shafts.

13. Bahira. Terminalia Belevica.

A large, straight forest tree with white timber. 
14. Toon. Cedvela toona.

Indian mahogany. Timber fine, well coloured, used for furniture.

15. Imli. Tamarindus Indica.

Tamarind. Very beautiful, large stem, eatable pods.

16. Nim. Melia Azaderachta.

Beautiful ash-leaved, shady tree.

17. Burgad. Ficus Indica.

Banian.

18. Pipal. Ficus veligiosa.

Sacred tree.

19. Paker. Ficus venosa.

These three figs grow to an enormous size.

20. Pulas or Dhak. Butea frondosa.

Stunted. Flame-coloured flowers.

21. Kikar. Acacia Avabica.

Camel-thorn. Produces gum Arabic.

22. Khair. Acacia catechu.

Bark produces catechu.

23. Bel. Egle marmelos.

Medicinal fruit.

24. Sissoo. Dalbergia sissoo.

Very hard wood, most useful in India for spokes of wheels.

25. Bans. Bambusa stricta.

Solid bamboo, used for lances and sticks; very strong.

26. Bambusa tulda.

Giant bamboo; grows 70 feet long; used for a thousand purposes; hollow, very strong. There are over fifteen different species of bamboo in India. There is an immense export of bamboo floated down the rivers.

27. Phanix dactilifera.

The date-palm. Grows well everywhere. 


\section{Phonix silvestris.}

Wild date-palm. Very common.

29. Tar. Borassus fabelliformis.

The toddy-palm or Palmyra-tree. There are some fine specimens at Gorakhpur, growing to a surprising height for so slender a stem, with fine leafy head of great fronds. In its native forests in Southern India it is, next to the date-palm, the most valuable tree, and is used as timber for rafters split out of the stem. It is nearly the strongest timber known, hard and black. Its leaves are plaited into mats and baskets, and make paper for writing on. The top is tapped to make sugar and toddy. It is a beautiful feature in the Oriental landscape. It is very slow growing, and has a sappy pith inside; outside it is as hard as iron.

Of palms there are the cocoanut-palm (Cocos nucifera); the sago-palm (Arenga saccharifera); in Bengal three species of palms: Corypha umbraculifera, C. taliera, C. Gebangaall useful for numerous purposes. The areca-palm (Areca catechu) is the most slender of all, growing to 80 feet high, with a stem only a few inches in girth. This and the cocoanut only grow near the sea. In Upper India palms are comparatively rare, and do not, as is supposed, always adorn the landscape; but they grow well wherever they have been permitted to remain-in parks and gardens and some jungles, where they have been planted.

30. Bet. Calamus Rotang.

A genus of palms, Calamus, of which there are fifty-eight known species. It has many representatives in India, the Rattan or Malacca cane being the stoutest. The more slender sortsC. gracilis and C. scipionem-abound on the edges of rivers in the Terai and the Assam hills, the ropes winding in tangled coils several hundred feet long, all armed with thorns and furnished with graceful, palm-like leaves. From these canes the celebrated suspension bridges of Sylhet are made, being often alive and actually growing while spanning great torrents. The split-cane-work for chair-bottoms and furniture, known all over the world, is woven from this material.

The above are a few of the most remarkable forest products deserving notice which abound in the jungles of India. 


\section{CHAPTER XIX}

JUNGLES IN CENTRAL INDIA AND BUNDELKHAND

IN January, I866, my duties as Forest Surveyor of the North-West Provinces led me to the districts of Jhansi and Lalitpur, where my instructions from the Secretary to Government, North - West Provinces, Public Works Department, were to explore all the forests to be found, and make a forest survey of them on the scale of 4 inches to the mile, showing the area under timber, and giving a schedule of the number of trees per acre, first, second, third, and fourth class, and other information. The railway was not then completed to Gwalior, and travelling was by night by dak gharry from Agra to Gwalior.

I arrived at the cantonment of Morar, a wide-spreading, neatly laid-out station of the British army, with beautiful straight roads shaded by bright green mango and other trees, barracks and bungalows peeping among the foliage. The stern old fortress of Gwalior is visible, dominating the extensive native town. It stands on a rocky tablemountain some 200 feet above the level, rising sheer up out of the plain, on all sides a solid perpendicular wall of rock, only accessible by the zigzag road cut in the face of the hill, where, perched upon the top, stands the celebrated old gateway in the fort, surmounted by blue enamelled domes glistening in the sun. That this apparently impregnable fortress has been twice taken by British 
assault - first by Wellesley in the Maratha war, and secondly by Sir Hugh Rose in the Mutiny-speaks wonders for the pluck of our soldiers. After its recapture from the mutineers, and the reinstatement of the faithful Sindhia, the fort was garrisoned by H.M.'s 52nd Regiment, whose hospitality I had previously enjoyed. The mess-room in the old Maratha palace had a most interesting outlook through a large window in the stern old walls, facing the native city, which lies in the plain below, buried in green foliage, with the roofs and minarets peeping through the trees. At night the twinkling of numerous lights and the hum of a teeming population contrasted with the strains of the regimental band playing in the old courts of the palace.

Having procured camels and tents, my march through the jungle districts of Bundelkhand commenced. They were wild districts, and there were many stories told among the villagers of Tantia Topi and his followers having fled to these jungles and made their last stand.

The Jhansi division, now under a Commissioner, includes the districts of Jhansi, Lalitpur, and Jalaun, which formerly contained extensive forests; but, owing apparently to the natives having worked the iron deposits found in many places, the timber had been cut down, and little remained but scrubby bushes and long grass, which covered extensive areas. These are called dhangs, and are used for grazing cattle and cutting grass and firewood for use at Jhansi.

There is a large area of country waste and capable of growing fine timber. Teak thrives well, and is found along the banks of the Betwa river, but no fine trees exist, except the usual fruit-trees, mahuas and mangoes, which have been protected by the natives; also the pipal and banian. There is no object in nature more venerable 
and charming than a banian-tree, with its huge fantastic stem, and roots hanging down like ropes, many of them struck again in the soil, forming, with the spreading branches, rows of cloister-like pillars and arches, beneath which a whole regiment might camp in deep, cool shade.

The jungles proper, however depleted of useful timber, only need time and protection to produce a fine growth of young trees, such as teak (Tectona grandis), sissoo, saj, and other kinds. The beautiful siassa (Dalbergia latifolia), or Bombay rose-wood, is also indigenous, and ebony (Diospyrus) is very common, though only in the sapling stage-an extraordinary black, broad, leatheryleaved tree. The march to Jhansi was through a jungly, open plain, with villages interspersed, and game of all sorts was often seen-antelope (hiran), gazelle (chinkara), blue bull (nil ghao), spotted deer (chital), and other game, including the beautiful little four-horned deer (chausingha), hares, pea-fowl, and partridges.

My camp is pitched near a village under an enormous pipal-tree. The camels, which have carried tents and baggage, are lying tethered by a neighbouring tree, and are munching their bhusa of barley straw, occasionally grunting or gurgling in a sleepy way. The horses are tied to pegs before and behind, and are being groomed by their syces, while the grass-cutters empty before them their loads of $d u b$ grass, scraped up by the roadsides with an iron digging tool, roots and all, from which the dust is well shaken.

The cool evening shadows rapidly lengthen, and the sun disappears like a crimson bowl under the horizon in a blaze of scarlet mist; darkness comes on at once, and the still air as quickly falls in temperature from about $80^{\circ}$ to $40^{\circ}$. This is the time to guard against the chill which produces fever. One soon finds the necessity of 
keeping in the heat of the body by wrapping oneself in a long Kashmiri choga, well padded or of heavy camel's hair, over the warmest English woollen garments one possesses. The luxury of a fire at the tent door can sometimes be enjoyed when in the jungle, but not always. After dinner, taken by the light of candles in glass shades, and a cheroot, one soon turns in between thick blankets, and sleeps the sleep of the tired. One is seldom disturbed except by the occasional growl and bark of the dogs chained not far off, and the rush to the door of the spaniels, which sleep in the tent, ready to keep away all intruders. The servants, sleeping wrapped in their blankets and rezais under the verandah, form a sufficiently watchful barrier against thieves or prowling pariah dogs, which otherwise would infallibly invade the premises. Two large Brinjara hounds, Bigli and Begum, and a powerful Scotch deerhound, Effie, in charge of Munnoo, the mehtar, would, if loosed, make short work of the most daring robbers, who, knowing what the dangers might be, take good care to keep clear of such a sahib's camp. Otherwise, in these jungly districts, night dacoits might be quite readily in evidence. It was wise also to sleep with a loaded revolver under one's pillow, and guns and rifles tied to the tent-pole handy. The marvellous stories one hears of naked, well-oiled black athletes creeping into tents and effecting clever robberies, and of ladies waking and finding nooses placed round their necks, and the robbers escaping and leaving no trail, except perhaps a murderous knife dropped on the dari, are too well known to be repeated. The actual incidents are, however, sometimes more incredible than the stories, and one does wisely to own a few really wicked dogs, and to carry as few valuables as possible when marching.

The habit of going to bed at dark necessarily implies 
an early awakening and a start at daybreak, or before, so as to get the march over before the sun, our natural enemy in India, gets too high. Even now, in January, his rays are unpleasantly hot at ten o'clock; and in February and March a very thick sola topi must be worn after 8 a.m. if one doesn't want to get a sunstroke, which, once got, perhaps disables a man for life. In a few minutes the tent and trunks are loaded on the camels, and we are off for the march to the next camping ground at a village some fifteen or twenty miles away across country, where perhaps there is no road, only a footpath from village to village, or through the jungle, where the cattle have made tracks leading from their night's lair to grazing grounds in the forest. They are now being driven out from the village, the cows, which have already been milked, lowing to their calves left behind, an old black buffalo cow with shiny back and long, back-drooping horns leading the way, big wooden or iron bells hanging from their necks to keep the herd together. One can hear the tanktonk of the quaint, deep-sounding notes a long way off, as they move slowly and graze on the green shoots springing from the roots of burnt grass.

At the margin of the forest, abutting on the bright green of corn-fields, a herd of spotted deer is still grazing. The graceful horns of a noble stag are raised for an instant, as he gazes at the intruders before darting into the thicket. In the open plain, crossing some ridge of bare ground with thorn bushes, a couple of chinkara are moving slowly to take shelter behind some rocks. As some venison for the larder is in request, we beckon to the syce, who trots along behind carrying a light rifle, accompanied by the dog-boy with the three hounds. Presently we have a stalk from the rocks, and get a shot at the best buck at I30 yards as he stands undisturbed. He is hit, 
but not badly wounded ; the dogs are loosed, and, mounting, we are off in pursuit, and the dogs strain every nerve to overtake him as he darts along the ridge. We keep him in view till he is run into, and venison is secured, and a nice pair of horns curving like a lyre, with slender points. The chinkara (Gazella Bennetti), or 'ravine deer' of sportsmen, is almost the same as the Arabian gazelle, which figures in Oriental fairy tales as the pet of the harem. It is common in Central India, always frequenting open ground, where ravines and thorn-bushes exist, in small herds of two to four together.

The forest is traversed and mapped, the timbering noted, and other observations made, and we get into camp in time for breakfast. The afternoon is perhaps occupied by a ride round on a long-striding sawari camel with a saddle holding two, the wooded country being sketched with the map and prismatic compass, a gun or rifle being always in the sling and ready for use if game turns up.

We generally encamp near some village, where the inhabitants cultivate the lands reclaimed from jungle. They are often fortified, with very ancient and crumbling mud-walls, and usually there is a picturesque temple and tank, where the rain-water has been held up by ancient embankments or bands.

They all have their headmen, sometimes a tahsildar or native tax-collector, and zamindars or landowners, who let out the fields to rayats or cultivators. There is also the baniya or shopkeeper class, the members of which are also money-lenders, who advance the money to sow the crops, in cash or partly in kind, thus making a double profit and becoming rich. They mostly, as in other countries, buy up the land and become zamindars. The Bundelas are a fine, tall, and handsome race. They dress in the brightest of colours and wear big puggarees. 
The women, who work very hard in the fields, are to be seen near the villages dressed in the usual Hindu costume, wearing coloured saris of strong cotton cloth, stamped with Grecian border-patterns, which fall in the most graceful folds. The limbs are draped from the waist down with double folds, and the loose end is then thrown over the head and shoulders as a veil, but the face is seldom concealed. Crowds of women or girls come at evening time to the tanks or wells to draw water, which they carry away to their houses in round red earthenware chatties poised on the head. The carriage and gliding movements of some of these oval-faced dark beauties, as they bear their heavy burdens away, is admirable to the artistic eye. The shops in the bazaar, where flour and vegetables and ghee are bargained for, are quite busy and picturesque places. The native artificers of all kinds and castes, working at their simple trades of lohar (blacksmith), chamar (leatherworker), and barhai (carpenter), using the same tools that were used at the time Solomon's temple was built, are to be seen in most village communities, besides cotton-spinners and carders of black wool, and weavers who make the universal black blankets, which every coolie carries, in primitive looms. There are shepherds (bheri wallas), who take the village flocks out to graze; a simple and patient race, clad in their own shiny brown skins, with blanket and stick, living each with his flock of sheep, mostly black shaggy little animals, and black-and-white goats, which are fine, tall, and picturesque fellows with big horns and long hair.

The cultivated land in Bundelkhand is mostly quite flat, with a deep black soil, known as cotton soil. It is an alluvial bed of black mud, in which are grains of white calcareous sand, and, being of any depth, is most fertile. 
In the rains rice is grown on its wet surface, and in the dry weather it cracks everywhere into a network of deep cracks, down which a horse may lose his leg. But they seldom do, being far too wideawake.

The plains of India, which grow two crops of food, and also cotton, flax, and wool for clothing, are very fertile. As the people do not require animal food, the soil can support an immensely greater population than that of northern countries, which grow only one crop in the year, and where most of the area is required to support cattle and sheep for the diet of a carnivorous race of men. It is a remarkable thing that the great alluvial plains of India, which have been cultivated for thousands of years, do not require mallure, and will grow crops without anything being returned to the land. The manure of the cattle, even, is burned. The great heat of the sun seems to draw up plant food from the black under-soil, and the very heavy rains restore ammonia to the earth. The modern farming systems of England, which cannot support its population (more than two-thirds of the foodsupply being imported, and most of the manure run into the sea), are by comparison very wasteful. That we are now drawing on America and the plains of India for linseed to fatten our cattle, and on Chili for deposits to manure our exhausted soil, does seem an unnatural expedient, and not the permanent system on which a self-contained country should depend.

It is interesting to observe the old, old process of cultivation still flourishing in the Indian villages. The plough, slowly crossing the unfenced plain, is made of a piece of rough timber which goes between the bullocks to the yoke across their necks, the ploughshare consisting of another piece of crooked timber, pointed forward with an iron tip, which burrows through the loose soil, casting it up 
at each side. A naked man follows, holding the handles and shouting to his oxen. The very modern invention for sowing corn to be seen at our agricultural shows, and called a drilling machine, has its very ancient prototype in the shape of a bamboo funnel attached to the plough, down which the seed corn is carefully dropped from the hand of a little black boy who walks beside, and delivered under the coulter. Surely there is nothing new under the sun. Without water the winter crops could not grow; wells, therefore, have been sunk in every field, and bullocks are driven round in a circle, working a primitive wheel, over which passes a rope belt with little red earthen chatties, which come slowly up from the clear cool well, dripping and full of the life-giving fluid, which is upset into a trough, and runs in its meandering channel to every part of the field. The same wheels exist in Egypt, and the broken pots or chatties are found 40 feet below the surface in the Nile deposit, proving the vast antiquity of this contrivance. In every cultivated field in the plains of Central India such wells exist, the clear water being found abundantly in the black, spongy cotton soil at depths varying from Io feet. The weirdest music, caused by the grinding together of the polished wooden cogs as the oxen go round, is heard all day on every side in different keys, and often at night-continuous moaning noises, varied by squeaks and groans.

At length the ancient fortress of Jhansi looms against the sky, with its bastioned walls and very antique citadel. The walls were 30 feet high all round the city, which was bombarded by Sir Hugh Rose in 1858 and taken by assault. Major Baillie most hospitably entertained me, and showed me the place where the escalade party had placed their ladders. Rushing in with a company of the 86th Regiment and some sappers under a heavy fire, they clambered on to 
the parapet and effected a lodgment on the wall, fighting hand to hand with swarms of the Rani's sepoys. The postern gate in the tower was then opened, and Sir Hugh Rose came in. The young subaltern of Royal Engineers who was first over the parapet, using his revolver and sword to good purpose, as described by Major Baillie, an eye-witness, was my brother, now Major-General C. E. Webber, C.B.

Our route lay southward towards Lalitpur, where forests are more prevalent, with rocky ridges rising out of the plain, and much ravine country covered with low thorny scrub, also wooded flats along the Betwa and Dhasan rivers, where teak and sal exist and other forest trees; many of which have been hacked about and mutilated by the natives, but a good deal is capable of growing good timber. There are some very curious ruins in the forest, near the Betwa river, of the deserted ancient city of Orchha. At one time this was a considerable place, with a fine wall abutting at each end on the river, and partly on an island, now overgrown with jungle. It is uninhabited, the Rajah and his people having removed elsewhere. It is now a city of the dead, judging by the immense number of Mohammedan graves to be seen in the ancient cemetery. They are neatly constructed of white material or stone, all facing the same direction (east and west). The Orchha jungles are the property of the Rajah, and fine teak timber is found in considerable quantity. The stream in the dry season is fordable, but in the rains it is a big river, running between banks of a good height, and impassable.

The Government, since the annexation of the country, had been very neglectful as to the forests, not only allowing the villagers to cut down their own timber recklessly, but permitting the entire area of forest, of which there 
is a considerable quantity* unoccupied by villages, to be devastated by the cutting of the best trees and the burning of charcoal. The price of timber for use in house building and for firing was, in the Jhansi and Lalitpur cantonments, exceedingly high, and even ballis or poles, used in the villages for all purposes, were very dear and almost unprocurable. There is a great quantity of iron ore in the districts, which was formerly worked by the native lohars. This accounts for the scarcity of timber in a country which is one-third jungle. The native rajahs were more careful of their forest rights, and preserved the teak and sissoo and other useful timbers carefully, so that in the Orchha jungles there were plenty of fine trees; and no doubt could be entertained that only conservation was needed to restore considerable areas of natural forest, now cut down, to a state of valuable timber production.

Trees in this climate, where great heat and an immense rainfall characterize the six summer months, grow very rapidly, and, if left alone, increase to immense size, as witness the enormous fruit-trees near villages and the sacred banians and pipal-trees. On the rocky ridges which rise out of the alluvial plain, crossing the country mostly in a north-easterly and south-westerly direction, excellent kinds of hard-wood timbers grow naturally, and only require to be given a chance. Ebony (abnus)† rosewood (siassa), $+\underset{+}{+}$ and sinse, $\$$ besides saj, mahua, and kahua, are indigenous, and teak would grow freely everywhere. Bamboos of several sorts, solid ones I2 feet long, and hollow large ones 30 feet and up to 70 feet long some-

* Jhansi district, 1,029,29j acres, of which 385,723 acres are waste land, including 57,862 forest.

- Diospyros melanoxylon.

† Dalbergia latifolia.

$\S$ Dalbergia oojainensis. 
times, used for a thousand purposes, are all over the country; but hacked about and over cut, and not given a chance to flourish. The villagers are not ignorant as to the value of forests, but where everyone cuts what he can, have simply been anxious to cut their share; and where the Government has neglected the conservation of the timber, the wasteful example is followed by every individual. Hence the importance to the welfare of a country of forest management being undertaken by the State. One day in open forest I came across a most astonishing object-the huge pyramidal stem of an unknown tree, about 50 feet in girth and about 40 feet high, with a shiny, flesh-like bark, and a tuft of greeneries at top like a very large carrot. This was the baobab-tree (Adansonia digitata) - a most surprising, if not to say beautiful, tree, reminding one of a gigantic bottle-gourd. I was glad there was only one, as a forest of them would have been too overpowering. How it got there, stuck up by itself, was a mystery unsolved. Perhaps some bird carried the seed, flying from Africa. Its timber is said to be porous and light and quite useless.

In these provinces, as in most parts of India, are to be found a race of jungle men, supposed to be the remnants of the indigenous inhabitants of prehistoric times. Here they are called 'Sahariyas,' and do not live in any fixed village, but crouch in bamboo and grass chappars or sheds, which they can construct very rapidly anywhere in the forest. They are a poor, half-starved and very black race, living on a very small grain, a kind of millet. They can cut down the largest trees with their small hatchets. But they are a monkey-like race, and prefer to cut off the branches, climbing with prehensile toes like apes. It is astonishing to see a man standing upright at the top of a lofty tree, grasping the boughs with his 
feet only, and taking a view over the surrounding country to mark the direction he wishes to go. I have had guides through the forest who occasionally went through this performance where the jungle was very thick and the view obstructed. They make remarkable guides, and their tracking powers are unerring. The Sahariyas are very destructive to timber production, as they have practised for ages the pernicious dahya system of cultivation, which has now been prohibited by forest law. The custom is to hack off the branches of all the standing trees in a likely locality. The boughs are spread over the ground, and when dried and withered by the sun they are set fire to, and every vestige of vegetation burnt, except the mutilated stems of the old trees, which are scorched by the fire. This is done just prior to the commencement of the rains. The ground is then covered with the ashes of the timber, which manures it sufficiently to grow a miserable crop of millet, called kutki and tili. The seed is only scattered on the ground, no ploughing or cultivation being attempted. When this crop is saved the Sahariyas move on to another square of the forest, and begin lopping the branches for the next year's crop, returning to the same ground only once in ten or twelve years, when a new supply of branches has grown. The mutilated stems are spoilt for all timber purposes, and become knotted, gnarled, and hollow, and occupy the ground which would grow good timber.

The Sahariyas are a very different race from the Hindu and Mohammedan conquerors of the country, who, as in other countries, have taken all the best lands, and driven the aboriginal races into the jungles and poorer hilly districts. They have no caste, speak very little Hindustani, and have a language of their own. They are quite as clever at their own business as the Hindu rayat, and far 
cleverer in jungle-lore and hunting and tracking, and fashioning of implements out of hard wood. Their women, who have few wants and live in the jungle, are good dressers of skins, and weave mats of bamboo, and make themselves a sort of thatch of leaves on a bamboo frame, which they carry over their backs in the rains to keep off the tropical downpour. They each possess a hatchet, which is stuck in their only garment, a cloth round their loins, and are as dirty and black as other savages. They worship the same fairies of the rock, flood, or forest, which our ancestors in Europe reverenced. They are a simple, well-disposed people, not treacherous or cruel or given to robbery; at least, one does not see any symptoms of those characteristics.

There is another interesting casteless race of the wandering type, which exists in the jungles of the Central Provinces. They are the Brinjaras, corresponding to our gypsies or Zingari. They are met travelling with carts, donkeys, and ponies, and always dogs of their own peculiar breed, as swift as greyhounds, and powerfuljawed, courageous, and fierce. The Brinjaras are said to eat anything they can devour, jackal's flesh preferably, which their dogs easily procure. The latter will tackle and slay the great jungle wolf, and pull down nilghai easily. The two Brinjara dogs which I possessed, Bigli and Begum, were worth anything to bring big game to bag, and most clever at cutting off a wounded buck, hunting by scent as well as by sight. They were quite as fast as the Scotch deerhound Effie, but very different in disposition, being sulky and treacherous with strangers or other dogs, though faithful to their masters; whereas Effie was demonstratively friendly and affectionate, and would not hurt anyone. They always went for the hindlegs of a deer, whereas Effie went for the throat. They 
would make short work of a strange pariah; if he made himself at all obnoxious and then ran away, they were after him as a coward, and gave him one chop across the loins with their vice-like jaws, which generally did for him.

Lalitpur is a large district south of Jhansi, with considerable forest tracts by the rivers, where teak is indigenous. At Deogarh is a very curious old fort enclosing a tableland of about Ioo acres, overlooking the Betwa, quite in ruins and overgrown with jungle. The tank still remains, and is covered with wild fowl. At Dudhi is a beautiful Jain temple of great antiquity and quite perfect ; the carved figures in the doorways and over the walls are in very hard stone, and finished with great taste, displaying most spirited processions of females and ancient deities. There are rocky hills with a considerable variety of trees, but there has been much destruction of timber to supply the iron smelting which was carried on by the native lohars at Nuthi Khera and elsewhere. The old mining pits are met with, where very rich dark-red ore abounds, but are now scarcely worked. The manufacture of catechu from the khair-tree is still carried on by the natives, and gums and frankincense are extracted from the trees.

In the ravine districts of Lalitpur, where wolves were not uncommon and sometimes carried off children from the outskirts of villages, I came across a band of four great wolves one day in bare, broken ground. Looking over the edge of a ridge, I sighted the band in the next hollow, engaged on the carcase of a deer they had doubtless run down. Instantly pulling myself back under cover of some thorn-bushes, I watched them at about Ioo yards, waiting for my rifle to be brought up by my shikari, as I had only a shot-gun in my hand. They were 
too busy to look up. Formidable-looking beasts, with long gray hair and bushy tails and big, ugly heads and teeth white and glistening, they tore frantically at the bleeding carcase and snarled at one another. How I longed for the rifle, but it did not come. The wind was not unfavourable, and I crouched, breathlessly watching and not moving my head; but wolves' eyes are pretty sharp, and one of them must have seen, or heard, or smelt that danger was near; and, leaving the dinner he was enjoying, he began to slink off with the peculiar skulking motion of the surly wolf, not going away straight, but circling around to make observations, yet giving no warning to the others. Soon another one disappeared, seeming to vanish. The man with the rifle was coming blundering along. Beckoning him to crouch, I at last got the rifle, and again peeped over the ridge, rifle cocked and ready. The brutes were gone. Walking stealthily forward, I searched the ground for sign of them, but could see nothing, though they were stalking me from different sides. At last, seeing two men advancing, one gave me a chance as he slunk behind some bushes. I fired, and the bullet struck the branches and missed its mark. I did not see them any more, and was glad it was early morning and not late at night, as four wolves together are not an agreeable sight. They look so huge from the amount of hair they carry.

The same day a native brought me four young wolves in a basket. He had found them in a burrow, and dug them out for the Government reward. They were very fearless-looking, bright-eyed little hairy fellows, with sharp noses and ears erect and ready for anything. They were about twenty-four days old probably, and already knew a lot. Having heard of wolves rearing babies, I thought it a good opportunity to return the compliment 
and rear some wolves; so I procured milk, and the mehtar tried to feed them. They were hungry enough, and lapped a little. But next day on the march the basket was put on a camel, and the sun was hot, and the poor little innocents did not like the motion of the camel, and howled like puppies. They say that dogs do not perspire, which I think is a fiction, but I know for certain that wolves do, for these little beggars when taken off the camel were quite wet, though the day was just the usual winter temperature with a bright sun-hot by day, cold by night. Anyhow, it did not agree with infant wolves, and one died. We gave the others all possible attention, and milk ad lib., and had them carried by a man; but they did not appreciate our kindness, and looked more and more miserable, and howled half the night, so had to be put an end to. At evening a wolf came about the camp and was seen, causing much alarm among the servants. I watched for her with rifle and shot-gun, but never got a shot. It may have been the mother following her young family. We were not sorry to be rid of the juvenile wolves.

The march through the districts of Jhansi and Lalitpur occupied three months of interesting exploration. The climate was quite beautiful up to March, when the sun by day began to be strong.

The route lay through Talbehat, where one meets the salt hedge. I breakfasted with a Mr. Graham, who was on duty patrolling the hedge. This extraordinary barrier was here composed of thorn-bushes, not planted, but just heaped in a long line some 6 feet high, which an animal cannot easily burst through. It is indeed a long line, extending all across India, so as to enclose the saltproducing region in Rajputana and other States. The salt which was there obtained was carried, on ponies and 
carts and camels, in caravans which took the salt by various routes to the south and east of India. It had to cross the salt barrier somewhere in British territory, and pay the duty ; by which a very large revenue was obtained, with a minimum amount of hardship to the poor, as it was divided minutely over so large a population.

There were chaukis (posts) every three or four hundred yards along the entire hedge, where armed chaukidars guarded the line to prevent smuggling. They could shout to one another for assistance in case of caravans trying to burst through, but practically this seldom happened, as the country was too open for concealment, and the checks against carrying untaxed salt were effective. But the system was an expensive and clumsy one. It was said that news often travelled by the shouting process along the entire line in a surprisingly short time. The two greatest sources of revenue from indirect taxation in India are salt and opium-one a necessary, the other a luxury. The former tax falls on the poor natives, the latter mostly on rich foreigners. Strange to say, there are wise politicians who would abolish the opium tax for India, while retaining the spirits and champagne tax for England.

The district of Jalaun does not contain much real forest. The consequence is that the climate is intensely hot and the soil utterly dried up, except in the rains, when the ground, unprotected by trees, is washed away constantly towards the great river Jumna. There are miles of ravines, all sloping towards the river bed, eaten out by the rains. Far back they are only slight indentations, which, lower down, become deep nullahs as the smaller streams unite, like the ramified growth of a tree or seaweed with twigs, branches, and stems. An entire district is permeated by these winding, branching valleys. 
It is easy to get lost in them, as all are exactly alike, and the labour of climbing up the ridges to ascertain the direction is considerable. While following the hollows one can see nothing, and must walk by endless windings one knows not whither. One cannot imagine a more desolate and utterly bewildering place to get into. The direction in which the nullahs run is quite uncertain, so that following them takes the wearied wanderer alternately in every direction, and the heat of the sun beating down into the hollows is something appalling. The chief sound to be heard is the sighing of the hot wind, always sweeping on from the north-west. The few straggling stalks of bent grass which find root in the caked, hard soil are always waving in the breeze, and the dust flying around. The scarcity of timber in these fertile plains is much felt by the villagers, and, having no firing, they must use all the cow-dung, which ought to manure the land, for fuel (called upla), the odour of which is strong. Then there is the constant chirping of the crickets and cicadas, the sound of which quite fills the sultry air. These sounds and smells, and the never-failing heat of the ground by night and the burning sun by day, must be felt and experienced before anyone can understand what India is like. The impressions are such as no other country produces. While the hot winds are blowing the heat is intense and like a furnace, dry and scorching, but not at all depressing or relaxing, except in the night, if the wind, as it sometimes does, ceases. But in the rains all energy is gone.

The plains south of the Jumna in the Jalaun district are very suitable to the support of the Indian antelope ( $A n t i$ lope bezoartica), commonly called the black buck, in Hindustani hiran. The natives do not molest them, from motives which forbid the destruction of animal life. 
They are, however, very glad to see some of them shot by the British sportsman, as they do much damage to the crops. In the early morning camp is struck, and we start on the march along a straight, well-gravelled road leading towards Jalaun. On both sides is a vast plain, smiling with fields of wheat and other crops of various shades of bright green. The sun is beginning its rapid ascent above the wide horizon. There are several herds of antelope in sight, grazing on the young crops. Having sighted some bucks with fine horns through the glasses, we stroll carelessly across the land, a syce leading the Kathiawar horse, which is a fast, smart mount for such occasions. $\mathrm{He}$ is a beauty, with black tail and mane, about 15 hands, of a light dun colour with stripe down back, and very sure-footed in a gallop across the cracked cotton soil. We shape our course, not direct for the herd of about twenty antelope, but at an angle which will take us near them, as if bound for a distant village, following the foot track leading thither. The bucks look up from their busy browsing and trot a little way towards us to inspect the intruders, but, seeing that we are going straight on our course and do not notice them, they continue grazing in peace. We do not attempt any concealment, which would arouse their suspicion at once. Selecting the finest buck, we keep him in view and edge along nearer to him, but still steering straight on to pass him on the left. He becomes nervous, and gives a few bounds and trots on, his curiosity leading him to come nearer sometimes; but seeing we do not alter our course, he grazes again, presenting his black side nicely at 200 yards. Watching the moment when his head is down, the opportunity is taken to sit down, while the syce leads the horse on without a pause. Resting the elbows on the knees one gets a steady position, and, aiming carefully, the express bullet 
flies to the mark, and strikes true behind the shoulder. The thud of the bullet is unmistakable, and he bounds away. The rest of the herd, startled by the report, fly in a troop, all bounding in the air with graceful springs, landing on all fours, and springing again in surprising jumps. Their coal-black sides and white bellies glistening in the sun, and with horns thrown back, they dart away at a great pace. The hornless females, with browngray coats and white tails stuck straight up, join in the mêlée. It is a beautiful sight to see the extraordinary height they will jump when startled. They soon disappear behind some patches of tall bajra, but the stricken buck separates from the herd and shows signs of distress. Presently he lies down, and another bullet reaches his heart, when he is gralloched and loaded on the horse. His horns are 24 inches long and beautifully set; his head, being above the average, is preserved for setting up, and now graces my collection.

Jalaun is an old native city with some crooked, narrow streets and native buildings of imposing flat-roofed structure. It is not at all metamorphosed by British civilization, but purely native. The principal officer was the tahsildar, or native revenue collector. In the evening this gentleman came politely to pay me a visit, and salaamed in the most courtly fashion, wishing me happiness and prosperity. To my surprise he spoke perfect English, but with a sort of shy manner and accent, as if he seldom used the language. Having been seated in a chair, he presently spoke of England, and said that his name was Stanley, that he had been as a boy at Eton, and came to India very young. He had had misfortunes and a wild career, and had married a native lady, and was now tahsildar in Government employment, and lived like a native, and had almost forgotten his native language 
from having none but Asiatics to talk to. He had not been in England since his boyhood, and never should go there again. He looked exactly like a high-caste Hindu gentleman, and wore long hair under his white turban, and a beard, and native white costume. He gave me much information about the district, and told of some strange adventures and recollections. 


\section{CHAPTER XX}

\section{THE NERBUDDA}

IN the great central plain of India there is a point which is the highest between the eastern and western ocean. Its name is Amarkantak, and its elevation is 3,494 feet above the sea. It lies in the Central Provinces, in the range dividing those districts from Bengal. Compared to the mighty Himalayas on the north these are poor little molehills, yet they are the great divide or watershed whence flow four fine rivers, draining a vast area of wellwatered country. To the east flows the Mahanadi to the Bay of Bengal, where the sacred temples of Jagarnath and the Black Pagoda rear their sacred pinnacles. To the south flows the Godavari, bordering the Nizam's dominions. To the north flows the Sone to join the mighty Ganges; and to the west, winding through jungle-clad ranges through Jabalpur, forcing its way westward between the two mountain chains of the Satpuras and Vindhyas, ever increasing in volume as it bursts its rocky barriers and emerges beneath the western Ghats-second only to the Ganges-flows the sacred Nerbudda, falling into the Gulf of Cambay, near Baroda.

Let us follow it through its rocky channel carved out between high walls of marble rocks, near Jabalpur; past the Gond fortress of Garha, where is the Madan Mahal, palace of a powerful Gond king, whose dynasty gave place 
to that of Hindu conquerors. Its waters in the dry season are here placid and clear, and one can row in a small boat lazily under the white cliffs, well polished ridges of rock, like white whales' backs, alternating with black basaltic pinnacles showing over the green surface. The rocks at each side are water-worn from top to bottom, and their solid substance cut straight down and smoothed. Surely so tremendous a cleft could not have been eroded by such a sluggish stream. One must view the Nerbudda in the rains to understand the force of its rushing waters. Between the territories of the ancient Gond races and the mountains of Mahadeo on its south bank, and the kingdom of Bhopal, celebrated for its Sanchi topes and its Begum, and the Vindhya hills to the north, the great river flows ever westward. At Hoshangabad its banks are 50 to 60 feet high above the rocky stream-bed. There is a full mile across the river from bank to bank. The stream in the dry season occupies but a tenth part of its channel, and is not too deep for elephants to ford it easily. It is at the height of the monsoon that the grandeur of this mighty floodway is properly seen. Then the banks are full up to within a few feet of the top, with a great rushing sea of turbid water. Viewed from the top of what were before high cliffs, the river races onward just beneath one's feet; and the whole landscape seems to glide away westward, only the distant blue hills of Bhopal appearing against the sky above the moving sea. Far out in the centre of the current a great line of floating objects goes along. Great trees torn up by the roots sail steadily onward, their heads and straggling limbs and branching roots rolling alternately above the raging torrent. Houses and logs of timber, and the bodies of cattle and sambur deer, and even human remains, float away in constant procession, carried by the resistless force of raging waters 
on their long journey of many hundred miles to the ocean.

What a stupendous force, which is gradually levelling down the land and sinking it in the sea! How many million tons of solid earth and sand and stones are whirled along by this great river daily or weekly would be hard to calculate. The mass of water, a mile wide and 50 feet deep, moving along for days and months together, is a spectacle that fills the mind with wonder and awe. The sky is lurid with heavy rain-charged clouds, at times discharging torrents of drenching warm rain. At times the thunder rolls, and flash after flash of vivid lightning rends the sky, and again the surface of the torrent is whitened and lashed by the howling hot tempest. There is a cataract through a narrow gorge 200 miles lower down, near Chandgarh, where the Satpura and Vindhya hills close in upon the Nerbudda. The river has worn a passage for itself between solid masses of rock which are quite close together. How does the great river, when in flood, pass through this narrow gorge? That I have not myself seen; but when crossing the river at low water in the month of May, then about 60 yards wide, in a small dug-out canoe, it struck me that it must be at full flood equal in volume to several Niagaras.

The forest bungalow in which we spent the hot season* when I was employed as Deputy Conservator of forests in charge of the Western Division, Central Provinces, stands on the banks of the Nerbudda at Hoshangabad. The bungalow is a large straggling, thatched, typical Indian habitation, with very wide verandahs all round, and a wide chappar shed, on strong posts, forming a shelter outside in the garden, which is a large one, with

* This was in 1870 , when the writer had returned from furlough in Europe, a married man. 
some beautiful pipal and nim trees shading its walks. There are also fine mangoes and stately mahua-trees, which afford dense and delightful shade. Behind is a grove of sissoo and tamarind trees (Tamarindus Indica).*

The natural herbage of senna bushes and jungle grass comes up under the trees. A trellis shades the verandah, covered with trailing moon-flower, a giant convolvulus which opens its large white blossoms only at night. The gayflowering bignonia grandiflora, a mass of orange trumpet flowers, climbs over the porch, and the purple bougainvillea flourishes. The garden is bright with poinsettias; at seasons with roses, and pomegranates with shiny leaf and scarlet blossoms. A native gardener did his best to grow English vegetables from seed, but was not very successful. He did better with pine-apples and melons, and oranges and lemons, and big pommeloes. Guavas also grew well, bearing fruit like inverted pears, but the mangoes were a wild, ungrafted sort, and very sour and turpentiny, though with scarlet cheeks streaked with bright green. There were some fine old mulberry-trees, which bore a great crop of fruit, which the natives save for their own use. A wooden clapper is fastened in each tree, and made to work by a little boy, who pulls the string to frighten depredating birds away. Lettuce and pineapples were plentiful in beds, irrigated in the dry season from the cool, deep well. A pair of bullocks walked up and down an inclined plane, with a wooden yoke across their necks. When they came to the top near the well, the bheesty lowered the bucket, consisting of a large bag

* This is a glorious tree, resembling a giant chestnut in the fashion of its gnarled trunk and branching arms. The foliage is, however, of a deliciously feathery and graceful softness, light green, with finely serrated fronds. There are specimens growing on the river bank whose stems measure 24 feet in girth. The pods, like pea-pods, contain sweet eatable seeds, on which sheep feed greedily. 
made of a cowhide, into the water. When they went away down the track they drew up the bucket, full of clear fresh water, by a rope over the pulley. When it came up it was upset automatically into the water channel, which was led to all parts of the garden in turn. What with the tropical heat and moisture, the crops grew surprisingly quickly. When the hot winds blew in May against the west verandah, the bheesty brought skins full of water and dashed them against the cuscus tattis which hung in the doorways. Inside, in the large rooms, matted with palm-leaf woven matting, it was cool and dark, about $75^{\circ} \mathrm{F}$., a breeze always passing through.

Adjoining was the daftar, or forest office, where the forest maps and statistics and accounts were made up on large sheets in prescribed form for the annual report of the Western Division. The forests under control of the Deputy Conservator comprised 2,400 square miles of woodland, mountain, and jungle, in the Nerbudda district. The annual report, a voluminous document describing the work of the year, had to be prepared, with maps and accounts of receipts and expenditure, amounting for the division to Rs. 92,7II and Rs. 88,470, and an immense number of returns sent as prescribed up to No. 60. The Government of India requires an immense amount of clerical work to be done by its departmental officers, and returns are multiplied excessively, budget estimates and specifications being required for every trivial expenditure. The forms are apparently designed to give work to clerks, and to cause delay in actual work. They would be no check at all on a dishonest officer, yet seem to imply that no official is to be trusted. That the country is magnificently served by its officials is due, not to this modern system of accumulated clerical checks, but to the fact that the officials are men educated in English 
public schools, where boys are trusted as gentlemen, and the French spying system, the product of democracy, is happily not yet discovered.

The garden was overgrown and tangled, but the growth of crops was surprising. Quite a nursery of young teaktrees had grown from seed put down in the spring, after proper steeping of the hard nut-like capsules. They were now nearly a foot high, with a few gigantic leaves unfolding. The teak leaf is a huge one, up to 24 inches long and $\mathrm{I} 8$ broad. The experiment was being tried of planting teak in the plain by the Nerbudda, as more convenient for the portage of the timber than the Satpura hills, where the forest plantations were. The teak-tree would grow much faster in the deep alluvial soil of the plain than in the rock-bound hills, where the roots could scarcely penetrate, and where the cost of planting and digging and clearing the ground was considerable. The most valuable timber tree in India is the teak. From its immensely strong, heavy, straightgrained timber the decks of our most modern iron-clads and the best railway-carriages in England are made. Its breaking strain is greater than that of oak. It still exists in extensive forests in Burmah, where the Forest Department has its finest reserves; but in India the old trees have been so steadily hacked down and used up without thought for the future that a mature teak-tree is a rarity.

There were many localities in the Satpura hills where young teak-trees were to be found growing naturally, but only scattered here and there in out-of-the-way and rocky ravines. The seedlings which grow naturally, or are planted out in the forest plantations, if they are not withered by drought in the hot weather, or scorched by jungle fires, make most enormous shoots, the saplings 
reaching 25 and 30 feet the second season, straight stalks with half a dozen leaves on top.

If fires are excluded for a few years these seedlings will rapidly become secure from injury. In the Madras Presidency at Nilambur there is a plantation of teak, made by an enthusiastic lover of forests-Mr. Connolly-in I844 to $\mathrm{I} 857$, now of 3,500 acres. According to statements of Colonel Beddome, Conservator of that district in I885, some of the trees then measured 8 feet in girth and IIo feet high, being straight and yielding good timber. The trees, planted $\mathrm{I}, 000$ to the acre, would be eventually thinned out to about seventy trees to the acre, of 200 to 240 cubic feet each at sixty years old. This is a surprising growth, considering that oak takes 250 years probably to attain the same size. The same authority stated that in the sapling stage of their first ten years teak-trees put on $I$ to 2 cubic feet annually, and grow chiefly in height, with single stems, but that their growth is then much accelerated, each tree putting on from 5 cubic feet a yeargrowing, in fact, four times as fast as oak. In view of the fact that the yearly export from Burmah to England, which averaged for many years half a million in value, has been on the decline, owing to the large timber becoming exhausted, the importance of conserving the teak forests and replanting becomes apparent. An experiment of planting teak in a forest reserve called Banka Burda, in the Satpura hills, was in progress ; but it seemed that a wrong place had been selected, too far from carriage. It is now abandoned. If Government plantations had been made on a large scale on Mr. Connolly's system, what a splendid property would now exist!

We will proceed to explore these extensive jungles. The road is but a cattle track winding along the bottom of a rocky valley; on each side rise moderately steep ridges, 
all dense jungle. Having marched on elephants some twelve or fifteen miles, always in a south-westerly direction, and seeing no end to the succession of ridge and valley and dry river beds, we at length come down to an open glade, where runs a beautiful clear stream, and our white tents, sent on on camels, stand on the flat under shady trees, ready to receive us.

Near here is a village of the aboriginal Gond inhabitants. They live partly in caves under the rocks and in little grass-roofed sheds, and are more like monkeys than men ; but they are the best shikaris to be found anywhere, and a quiet, well-conducted race, living by herding cattle and the chase of wild animals. They are naturally very skilful in tracking, as they possess no firearms, and use only spears and bows and arrows. They are said to slay the greatest beast of the forest, the gaur or bison, sitting in trees over its path. When the herds are driven by other Gonds along the track, the spears are jobbed down into the gaur's back, and stick there till the animal dies of exhaustion. Every man, woman, and child carries a beautifully shaped light kulhari, or hatchet, made of native steel, with springy bamboo handle.

It is strange to see the little naked children, each with its diminutive kulhari stuck in its one article of clothing, a loin-rag, or using the tool neatly in felling branches for firewood. The women also have their hatchets, and can use them. The men have larger ones, and can fell a large tree with these light little tools nearly as fast as an American backwoodsman with his great axe, weighing five times the weight. The Gonds are very black, and of a low type of humanity; with snub features, but are extremely active and enduring. They live in the jungle, and do not cultivate land, except on the dahya system, by which great tracts of forest have been hacked away 
and destroyed and burnt, and much damage done. The Forest Department has done much to put a stop to this pernicious custom by taking up large reserves, where it is forbidden and the fires excluded.

Two more marches, through valleys and across low ridges, all dense forest, bring us to the teak plantation of Banka Burda. Here is a forest chappar or bungalow, built of wattle and daub, with a roof thickly thatched with the forest grass. It stands in a narrow valley high up among rocky hills, where a stream of clear water flows from perennial springs. There is a mud floor, and a verandah all round, and doors and windows are only apertures in the wattled walls. The Forest Assistant coming to inspect the planting operations puts up in this picturesque mansion, but a prolonged stay generally means a strong go of jungle fever. The work of sowing teak seed, and planting out the seedlings in nursery beds and eventually in the forest, is carried on by a jamadar with a staff of coolies. It is a pretty expensive operation, and a good many young trees die in the hot weather; but when once established they go ahead strong. The jungle is infested by tigers, which occasionally carry off the coolies, and it is the duty of the forest officer to shoot them, a duty he is not slow to perform.

The Gond shikaris brought in news in the evening that a tiger had just killed a cow, and was lying in a thicket in a ravine close by. At early dawn the camp was astir, and some coolies with torches and tom-toms were sent round to beat the ravine. A fine tiger was rolled over by the Assistant Conservator, and brought into camp by breakfast-time. Then there was a drive for bison. Some Gonds who knew the haunts of these great beasts, and where they mostly lay up in the heat of the day, and their well-worn paths across the ridges 
or up the valleys, were sent round to start the herd, coming down wind on them in dense bamboo scrub. The guns were placed at two ghats to command the most likely passes down wind, so that the gaurs should not smell the danger ahead. It was a long, silent tramp to reach our post, under the guidance of old Boodoo, a typical Gond shikari, who carried spare rifles. We wound our way by a mere track among rocks and gnarled trees, with a burning sun overhead and stifling heat all round, up to the edge of a ridge where the jungle paths converged in a sort of a pass or ghat. Here we remained concealed among rocks for a considerable time, overlooking the dry bed of a stream. The noise of some animal moving through the jungle was heard not far off, and the voices of Gonds in the distance coming nearer, and tappings of sticks against the trees. Some sambur deer made their appearance, cautiously stealing up to the ghat. These were let pass by, as bison were certainly on foot. Presently was sighted the head of a magnificent bull bison standing among thick bushes. His eyes were fixed on our position, and whether he smelt or sighted us crouched among the rocks, he evidently suspected danger and turned some other way, for he did not come on near enough for a shot.

There was no survey or correct map of the very extensive forests, comprising over 2,000 square miles, to be found in the office, and no one knew exactly what they contained. This deficiency I endeavoured to remedy from existing revenue maps, as learning the geography by marching twelve miles a day over a big country, though very interesting, is not a very rapid method.

These great ranges of rocky hills, all covered with sparse tree-jungle, with long grass in the hollows and beds of streams, extend from Mandla and Jabalpur to Bhusawal, a distance of 300 miles by 200 , of which 10,000 square 
miles are forest. There are large tracts which have been taken up by the Forest Department as Government reserves (classified $\mathrm{A}, \mathrm{BI}$, and $\mathrm{B} 2$ ). Other portions, where the forest is of a less promising character, are considered as open, unclassified forests, where it would not pay to exclude the fires. Here are the grazing grounds of great herds of cattle and buffalo, which are usually sent out to graze in the dry season, when fodder and grass are exhausted in the open village lands. The forests being Government property, a revenue is collected by the sale of permits for grazing, also on gums and other minor produce. There is a staff of forest watchers employed to guard the passes and collect the dues. The reserved forests are in the best portions, protected from fire by broad lines cleared of grass all round their area. It is considered that, as the expense of replanting is too great, it is better to rely on the natural reproduction from seed and old stools, which is always going on slowly provided the fire can be excluded. The difficulty of preventing fire from crossing these protecting lines is considerable during the very dry months of April and May, when the hot winds blow and the smallest spark will cause a great conflagration; but it has been generally successfully done, though sometimes fires occur. The jamadars in charge of the reserves, and their staffs, are rewarded according to the success of their exertions. When the rains come, then the danger of fire is past. The cattle are driven away to their villages, and the jungle is left to the wild beasts. The highest point of these hills is a fine rocky summit, called Mahadeo, as it is sacred to that primitive deity, the author of existence, represented always by the phallus.

There is a place of pilgrimage in a cave, where great numbers of seekers after the favour of the 'Great God' 
flock to his shrine. There is a well-worn and difficult path, which leads from the plains below to the sacred place, some twelve miles through rocky gorges and over jungle-clad ridges, in some places steep and even dangerous. The pilgrims come from great distances, poor and rich, men and women, to propitiate the deity who gives them children. They must tramp the toilsome ascent and present the priests of the shrine with suitable offerings. These well-to-do gentlemen, who live on the fat of the land, appear in the guise of jogis, covered with ashes or painted in bright colours, and ring bells and go through ceremonies at certain hours, chanting in a monotonous tone, after a fashion which seems common to priests all over the world. The pilgrims are then conducted into the cave, which is a natural one in the face of the mountain, whence a stream of cool clear water issues. They must pass through a well-worn basin of deep water before entering the holy place, where the image of the deity is carved in stone. It is said that many pilgrims get their death of cold from the sudden immersion after their hot and exhausting climb through the heat of the tropical sun; but this is part of the penance which priestcraft imposes on the credulity of the pious.

Near Mahadeo mountain is the plateau of Pachmari, well known now as a hill station or sanatorium for troops. It was then in charge of the Forest Department, and there existed only the forest bungalow and a gaol. The summit is a tableland of some extent, studded with fine and beautiful forest trees of various kinds, in groups or single.

The forest officer used to come there in the hottest weather, and the forest work consisted in ploughing the land with an English plough drawn by an elephant, with a view to making a nursery of trees and growing potatoes. This was before the present system of forest conservation, 
and before 'working plans' of forest rotation had even been heard of ; and officers had not been much instructed in the scientific management since inaugurated. The ideas possessed by the energetic officers who first stirred up the Government to pay attention to the forests were first derived from the British systems of arboriculture, which had not arrived even at silviculture, and which even to the present day know very little of the broad principles of forest rotation, extending over several centuries, which have been thought and worked out in France and Germany. When timber for building and firewood began to be scarce on the Rhine, the necessity which mothers invention opened the eyes of the Germans, who are a vorsichtig people, to the fact that timber might be grown on land not suitable to wheat, as a crop, and in a rotation exactly like a corn crop. If primitive man had relied on the natural growth of wild wheat here and there in the woods to supply bread for his children's use, he would have used his brains to as little purpose as do those who rely on forests which are left to chance for their replenishment, after everyone has had a free hand to cut away and hack at the store which nature had in thousands of years accumulated. The difference being that mistakes in growing corn can be remedied next year, but mistakes in timber-growing not under fifty or a hundred years. The peculiar situation of England, endowed by nature with vast supplies of coal, makes her less provident. It was the Government of India, under Lord Dalhousie, which had the distinction of establishing a Forest Department under the best expert supervision, and educating its officers in approved forest schools.

The improvement made in the forest administration of the Satpura hills since the Department has been established is now becoming apparent. In the report of the 
Northern Division (Central Provinces) for I899 the area of forest under protection is put at close upon 6,000,000 acres-over 9,000 square miles-all of which is classified and demarcated and under the care of a most efficient staff, directed by forest officers who have been trained in the best schools of Europe. The whole area has been laid out into districts, each with its 'working plan,' by which rotations of thinning, cutting, and reproduction are laid down for all future time. The receipts amount to $4 \frac{1}{2}$ lacs of rupees, and expenditure to about Rs. 396,000, leaving a net profit of about Rs. 50,000 for the year. The duties of officers comprise the carrying out of the 'working plan' of thinning and cutting, the regulating of grazing and sale of timber and firewood, the collection of revenues from minor products-including bamboos, lac, resin ( $r a l)$, harra (for tanning), mowha, tasar silk cocoons, gums and dye stuffs-and the furnishing a report and numerous returns up to No. 60 once a year, from which the returns for the whole of India are framed.* But as yet no mature crop has come into market.

Great areas of forest still remain in the possession of the communes and villages and private owners, so that the rights of the people are not encroached upon; but, under the protection of the Department, natural growth is steadily restoring the State forests to a condition of productiveness which by previous neglect they had ceased to maintain.

* In the Report for 1899, par. 91, is the following: 'General Health of Staff--The year was a comparatively healthy one : I Deputy Conservator, I extra Assistant Conservator, I Deputy Ranger, 26 Forest Guards, and 2 licensed vendors died, being a percentage of $2 \cdot 17$ of the strength of the entire staff.' Also : 'Shooting permits have been sold to 276 persons. Good heads are becoming scarce . . . and bison are diminishing in numbers, owing both to disease and their indiscriminate slaughter by impalement by the jungle population.' The above are significant entries up to date. 
To return to personal experiences during the time that I was in charge of the Western Division, as then designated. Leaving Hoshangabad on May 24, I proceeded by train to Harda station, on the Great Indian Peninsula, to inspect a report upon the little-known forest of Chandgarh, a jungle on the north of the Nerbudda, cut out of the Indore district. The hot winds were blowing with a force quite exceptional, a steady and furnace-like draught ever pressing from west to east. The train, bearing invalids to Bombay on sick leave to England, some of whom would never reach their homes, steamed lazily along, the steam from the funnel of the engine being quite invisible, the dust and dry leaves flying and curling and crackling along. The engine seemed overcome by the heat, and people's eyes were closed up and sore from the smoke and glare. There were coffins ready on the platforms of the stations, and the engine-driver's bottle of brandy in the tender was empty. The guard, in whose van I travelled for company, was cheery, saying that a man had had heat apoplexy, and was taken out of a first-class carriage dead at a previous station. To put one's hand out and let the hot wind strike the back of it meant getting burnt; to sit with one's head unprotected meant sunstroke. Luckily, the journey to Harda was not long, and camp had been sent on to Beera. Getting on a beautiful chestnut Arab at the sleepy-looking row of sheds constituting the Harda station, a smart canter along a smooth white road, shaded by nim-trees, brought me to camp under a glorious banian. The white tent looked home-like, and elephants and camels picketed around were like a travelling menagerie. The bheesty had the tattis at the western door of the tent well soused with water, and inside was cool and pleasant. When the welcome sundown came, and only with it a lull of the 
burning blast, the tent was struck and started on camels, only some khanats being retained to partially surround the charpai, which was placed on a dari in the draughtiest spot, where the breeze brought some coolness to the perspiring occupant. Four a.m. was the hour of awakening, just as sleep long wooed had come in earnest. A fifteen miles ride brought one to camp again, this time at the edge of the jungle. At dawn we crossed the Nerbudda in a boat. It is here that the rocks close in on its broad bed, narrowing the channel to a rocky gate. The camp was swept by a furious blast, and the sun glowered down from the zenith, a glowing ball of fire.

Next day and the next we rode an elephant all day through a trackless jungle. The trees were leafless mostly and bare, but by the stream banks were bright green masses of jamun foliage, like the cotton-tree of the prairies always following the winding, sunken course of the streams; but there was no water in those streams, only sand and rock and an odd yellow pool once in a mile or more.

We camped by one such pool, the only good-sized one in a thirsty land for several miles. At night the sides were taken from the tent to let a breath of heated air pass across the charpai, for it could not be placed out in the jungle. Next morning there were fresh tracks of a tiger and a panther and two bears, which had drunk at the pool about 30 yards from the tent. The mornings were spent in traversing the jungle in every direction to discover where timber might be found fit for sleepers. There is a handsome tall-stemmed tree called anjun (Hardwickia binata),* which grows commonly in Chandgarh. It has

* In Skinner's 'Description of Indian Timbers' this timber is described as a close-grained and durable wood of a very dark reddish colour; specific gravity, $1 \cdot 360$; it has a breaking strain much higher than teak. 
fine-leaved sprays of graceful, birch-like foliage for its crown. The timber of anjun is hard and heavy and fine in the grain, and when sleepers made of various forest trees were tried to prove their worth, the anjun sleepers stood the test better than those of teak or sal, remaining sound longer. Therewere no sal-trees nor teak in this jungle. There were plenty of tracks of great bison (gaur), but none were seen, though some Gond jungle men, who followed their tracks rapidly over the hard and rocky ground where no special track could be seen by the uneducated eye, pursuing steadily for some hours, did their best to bring me up to the herd. But night came on too soon, and we never sighted the great beasts. I had a shot at a bear which came to drink one evening at the pool. Unfortunately, the bullet struck and killed one of three cubs that were quietly asleep on the bear's back, not distinguishable from its coarse shaggy black coat. That bear came round the camp at night, when she had counted her little ones and found one short, making a loud and angry single call at intervals, which disturbed the camp a good deal. She came close up in the morning in thick bush jungle, but did not afford me another shot, and went off again, grumbling frequently.

The natives said that people who lived in this jungle were required by the fairies to perform certain pujas, otherwise they were generally taken with a deadly malady in the chest. The season of the hot winds is probably the healthiest time for visiting such places. Though the heat was intense on June $I$, and the exposure all day to a vertical sun very trying, one did not suffer at all from chills at night. In fact, the night was hotter than the day. Still, by wearing a thick cotton padded khaki jacket and a big puggaree, wound native fashion round the head during the heat of the day while riding 
an elephant or on foot, I found the heat quite bearable, and did not get fever. Ten days after, when the rains threatened and I marched back to Hoshangabad, I had an attack of sharp fever for a few days.

Large quantities of sal sleepers had to be furnished at a place on the Great Indian Peninsula Railway called Bagra, not far from Hoshangabad, where the last relics of a fine sal forest were being cut up for the use of the railway. The native method of sawing is ingenious. The logs are propped up in a sloping direction and cut with whip saws, one man standing on top and one below. Saw-pits were not used. Work in the forest came to an end in the rains, camping out and marching being impossible. Camels cannot carry loads over wet and slippery ground, as their big flat feet are more suited to dry and rocky soil. They frequently then slip and split up if loaded, and cannot stand a damp climate, dying like flies. Their owners drive them all back to the rainless Bikaner in the north-west, to graze on the babul or camel-thorns (Acacia Arabica) of those arid, sandy deserts, and bring them south again to be hired out in the dry season.

The rains at Hoshangabad can only be described as hot, relaxing, and incessant for four months. The normal conditions of life were mere existence, alternated with goes of fever; but sometimes there were delightful intervals of European-like weather, when one could ride abroad or take trips on elephants, which had to take all the messages to the railway station at Itarsi-ten miles-as the roads were impassable for carts. There is now a railway junction at Hoshangabad, and a fine bridge over the Nerbudda. 


\section{CHAPTER XXI}

THE BORI FOREST

In October, I870, after the rains were over, the forest daftar (office) and camp moved out to the district. It was proposed to hand over the plateau of Pachmari to the military for the purpose of a sanatorium for troops. The timber depot at Bagra was the site of our first camp. Tents were pitched under some giant mango and tamarind trees on the bank of the river Tawa, a large tributary of the Nerbudda. Here was a strange sight. The recently built railway bridge, about Ioo yards long, had during the rains been entirely swept away by the heavy floods which came down from the Satpuras. Stone piers, girders, and all were gone, and nothing remained but the rails and sleepers, hanging together in the air by the fish-plates in a graceful curve some 50 feet above the river, which was now a placid, clear stream winding and gurgling over smooth rocks. The traffic was conducted on a deviation, which ran down into the bed of the river and up again the other side. There are always many such catastrophes on a new line in India during the first and second rainy seasons.

Bagra is a lovely spot, with its huge shady trees. The park-like plain with cultivation mixed with forest, and the gorge of the river, on one side; on the south a rocky, tree-clad valley, and the ridges and ranges of the Satpuras 
rising one above another to some 4,000 feet, and fading away in the blue distance. The ground was still covered with the luxuriant carpet of rain vegetation, weeds and plants and shrubs of many curious kinds, senna being a common bush about 2 feet high, and rose briars and yellow-flowering Cassia fistula abundant. Lovely feathery mimosas and acacias formed the lesser groves by the river, and occasional tall, straight sal and saj trees towered on the hillsides above the numerous trees of the forest. One of our camps was near a village not far from the railwaystation, where we had to wait for some necessary equipment. It is fatal to pitch camp after the rains near a village, where the ground is soiled by cattle and villagers, no matter how beautiful and fresh the open fields may appear. The germs of fever are surely about, much more so than in the jungle. Here we were delayed by severe attacks of jungle fever, which affected natives and all alike. They would come shivering and off their heads in delirium, and throw themselves at the tent-door, raving and praying for dawai (medicine). Quinine, luckily, was plentiful.

The train from Bombay came by daily about breakfasttime, with its freight of healthy-looking arrivals from Europe, officials rejoining, and smartly-dressed young people, all full of hopes and excitement at the novelty of a strange country. Other trains went westward, freighted with the most depressing crowd of half-broken-down, sallow, carelessly clad, and weary-looking men, women, and children, to whom the wonders of the gorgeous East were a burden, and perhaps a terrible reminder of death and careers prematurely blighted. In the refreshment room we met friends of both categories, several quite unexpectedly; but were truly delighted to clear out on the earliest possible date from that camp, and move upwards 
into the hills, where higher ground and better air and quinine soon chased headaches and shivers and collapse away. The road lay by a winding route, ever mounting higher through miles of jungle-clad hills, only a bridletrack where elephants, horses, and camels could just get along. Gangs of coolies were at work repairing the damage done by the rains and widening the road. A camp was chosen at a long ago deserted village. Many such exist in all parts of India as well as in the poems of great writers. Here were the old terraced fields all grown over with dense thicket, where houses once stood. Wild orange and citron trees shed their golden fruit on the ground unheeded. The clumps of great wide-leaved bananas were choked by thorny trees and tangled brushwood. A grove of mango-trees left crowded together had grown to an immense height, with bare, tall stems, and a date-palm tree, with slender stalk fully I20 feet high, overtopped them all. There were planters of orchards in those days who had some intelligence above cutting down and selling, or spoiling earth's treasures for the sordid gain which is the high aim of modern industry.

The fields which were once ploughed were gone back into jungle and overgrown with grass Io feet high, the lurking place of tigers and leopards. The neatly built well, whose clear water issued from the mountain through a carved stone mouth, still supplied the thirsty traveller ; but the villagers were not there, and all that remained of the houses were some moss and fern covered stone walls, clasped by a network of pipal roots and shaded by giant fig-trees. The glory of the village was an immense banian-tree, standing alone and covering half an acre of level ground. This great tree, with a stem 50 feet in girth, continued to flourish and spread, with a 
mass of thick foliage through which no sunlight could penetrate. Here was room for tents and camp followers enough. The valley is sheltered on all sides by gently sloping hills, and a stream winds among overhanging stems. The wild flowers and plants and trailing creepers to be found would detain a lover of gardens many days. Here was a real wild garden overgrown with weeds, but weeds of tropical beauty and proportion; the very nettles were giants with spears half an inch long. The trees were swarming with beautiful bright birds, and green pigeons cooed softly in the high trees. Of these there are several kinds, some as big as wood-pigeons, and excellent eating.* The pretty little turtle-doves, with black ring and modest plumage, picked on the path at grain and fluttered in the bushes, and light-running hoopoes raised their fan-like crests, chasing the insects.

There is a strange black bird, once seen never forgotten - the greater racket-tailed drongo.t Here were several flitting from tree to tree, the long feathers, bare of web except a racket-like end, fluttering in the breeze. It was impossible to refrain from securing a couple of specimens (now in my collection), and skinning them carefully. I had seen the lesser racket-tailed drongo in the Terai, but this was a new find. The common king crow or black drongo shrike $\ddagger$ is a bird that no one fails to notice, sitting on every telegraph wire, and darting after insects, always returning to his perch. He is a tyrant, and permits no interference from other birds with his own hunting quarter. Among familiar birds is noticed the common Indian roller, which perches on telegraph poles, and pro-

* There are nineteen species of green pigeons in India, distinguished by Blanford, besides wood and blue pigeons and cushats; also nine species of turtle-doves.

$\dagger$ Dissemurus paradiseus, said by Blanford to inhabit Central India. † Dicrurus ater. 
gresses screeching, with a series of blue flashes, to the next pole. Called by the Hindu nil kant,* the sacred bird of Siva the Cruel, he is liberated annually in Hindu ceremonial, like the scapegoat, to bear away the small-pox and other inflictions. Everywhere flying is the lovely little metallic sunbird, $\dagger$ which dances as it flies, wings expanded like a butterfly, and then sails kite-like with angular tail, spiked with two long centre feathers. There are twenty different species of sunbirds distinguished by Indian naturalists, so profuse is the supply with which nature decorates the landscape. Some are purple and some yellow, and they shine in every sun-ray. Their little nests, shaped like pears, hang by a cord from the ends of boughs near the ground, and are beautifully woven. High up in the dark recesses of the banian-tree one hears all day the 'coppersmith' striking his anvil with metallic twang, the crimson-crested green barbet: with thick, strong bill. There are several sorts (sixteen species), smaller and greater, and they are very industrious.

This great fig-tree is in itself a whole aviary, affording both shade and figs, and insects and grubs, and safety from numerous enemies of the hawk tribe. There is the golden oriole (Oriolus kundoo), which makes a melodious whistle very like the ring of glass, short, single, and descending two octaves. In the heat of the day, as we sit in the broad tent verandah, many little squirrels, exactly like American chipmunks, come skipping and cocking high their bottle-brush ringtails, boldly venturing to our very feet to pick up stray crumbs as we take our tiffin, and scuttling away with a shrill whistle when too great

\footnotetext{
* Coracias Indica.

$\dagger$ Ethopyga seheria, green sunbird or honey-sucker.

¥Xntholama hamatocephala.
} 
bravery changes to sudden fear, as one can see by the change of expression in their little twinkling eyes; such inquisitive, bright little faces they have, which they clean often with their little hands. No one can be dull with such lively companions, which insist upon being noticed. Among the thick shiny leaves there is a sparkle of canaryyellow and bright scarlet; this is the female and male minivet* or cardinal bird. There are many kinds of woodpeckers, which tap on the stems and screech. A dark-greenish bird sits in the shade-the koel. $\dagger \mathrm{He}$ makes the grove resound with his frantic cry, ' $I$ 've lost my shirt!' When no one takes notice, he screeches in tones ascending ever higher: 'Oh mý oh, oh mý oh, oh my oh !' The air is full of swifts and swallows, darting ever after insects and twittering loudly to one another. At no time or place is there an interval in the wheeling of long-winged kitest high overhead, ready to pick up anything eatable with a sudden swoop, squealing at one another in a grating manner when two come at the same object. Towards evening, when the sun's glare is modified and shadows lengthen, a little owl says 'Piu!'§ from the recesses of the many air-roots which hang overhead. Then, as by a signal given, a hundred green paroquets screech all together at the top of their shrill voices from every tree, and begin to dart like green streaks across every open space at a pace which takes one's breath away. The green lines seem to run like electric flashes in every possible direction, intersecting one another in a mazy pattern like ribands in a pole-dance. The chorus of screeches is ear-piercing, and comes in waves. There are

* Pericrocotus speciosus.

† Eudynamys honorata.

+ Miluus gooinda.

$\$$ Like the Italian owl when spring comes: "Il fuoco nel letto non si mette "piu." 
flocks of the common large green paroquet* (tota), $2 \mathrm{I}$ inches long, and the smaller rose-collared tota, which roosts with the crows, and many kinds of plum-headed paroquets, and slaty-headed and red-breasted parrots of all sizes. Their noisy fit, luckily, does not go on for very long; but when it ceases, then begin the various evening and night noises which are more or less ventriloquistic sounds, hard to imitate or describe. There are notes of various owls, some plaintive, some snoring; the purring also of the goatsuckers which fly round with noiseless flight, their great throats open wide to swallow large moths and insects. Stag-beetles drone as they swing by, and cockchafers and the cicadas in the trees keep up a creaking which seems always in the air, and there is never silence.

These are the voices of the jungle, which speak to those who listen and try to understand something of the teeming life which Indian forests present. Each inhabitant talks to his own kindred, and uses a language well understood among friends, and gives warning of enemies. Each of the many thousand species in the list has its own place of abode for the season, and in its mind owns the land, and the feeding grounds, and drinking fountains, and night perches, and the nests which it builds, just as much as men own land and houses and bequeath them to their successors. Each group of migratory birds has its own summer and winter demesne, and takes its trip to the seaside or continent as regularly as clockwork, returning on the same date each year to its own fixed residence, in localities separated often by immense distances, sometimes in different hemispheres. Each builds in its own style of architecture according to correct and fixed laws. Who can say what is the extent of mind or intelligence possessed by these creatures? That they have clever-

* Palacornis nipalensis. 
ness to avoid danger from their known enemies is the condition of their existence. That they do not regard man in India as an enemy, which their extraordinary tameness shows, is a silent testimony from nature to the high* humanity of the Buddhist and Hindu religions, which look on animal life as, alike with man's, divine.

While noticing the birds of the forest, I must not forget the chandul. This is the crested lark, a bird much valued by natives as a singing bird. I purchased one in the Hoshangabad bazaar for the mem-sahib, price Rs. 50, or $f_{5}$ in those days. They are valued according to the number of animals they can mimic. They are taken in a small cage, closely wrapped in a handkerchief, to all the nautches, where tom-toms and fifes make music all night, and are taught to imitate every sound. The répertoire of our chandul included the cries of sparrows, swifts, parrots screeching in flocks, also squirrels, a horse neighing, goats' and cats' calls, a dog barking, bulbuls' sweet songs, doves cooing, hens cackling, and geese noises. $\mathrm{He}$ was a dear little bird, just like a skylark, but with long feathers on the crown of the head. The bearer had to take him out every day to 'eat the air' (hawa khana), and attend to his feeding on various grains and cake made with ghee, and to bring him every evening after dinner. The cage was placed on the dinner-table, when Chandul would go through his performance. A buzz of conversation always excited him to begin. It was the sweetest

* In a large native city in Central India I noted the gable of a small native house, which appeared like a honeycomb built of mud. It was actually over Ioo swallows' nests, so close together as to resemble an empty comb. In and out of the holes were flying innumerable swallows, so tame that one might almost lay one's hand on any bird. This was in the most crowded portion of the bazaar; the whole gable was about 9 feet high, so that most of the nests were on the level of the crowd of people who frequented the bazaar. 
little gentle whistle, beginning soft, but when he got to the sparrows fighting it was an angry sharp note. The imitations were perfect. It is impossible to imagine a cleverer or more charming little bird.

Camp is next moved to Pachmari. The Forest Department is, ordered to furnish timber for building barracks. Here we must remain in permanent camp for some time, and a temporary mess-house is run up by the R.E., of clean wattle and daub, thatched well with jungle grass for coolness. Before it became a sanatorium for troops Pachmari was a charming place, almost a wild jungle as nature made it. Here grew many kinds of beautiful trees, dotted about everywhere in groups. There were many fig-trees. Of these, besides the banian and pipal, there was the paker-tree (Urostigma infectorium), with stem resembling the banian, but without the hanging roots. It grows to an enormous size, some measuring 40 feet in girth, with noble spreading head and arms stretching out every side. Then there is the gular (Ficus glomerata or Urostigma glomeratum), a fine, shady, fig-bearing tree with spreading head. Then must be specially noticed the mahua-tree, which is, next to the mango, the most remarkable fruit-producing tree in India. It is even far more plentiful than the mango, which has been mostly planted by the zamindars in groves; but the mahua (Bassia latifolia) is a wild forest tree, and reproduces itself from seed all over India. In some districts the cultivated plains look like a continuous grove-like succession of round-headed umbrageous standard trees with great black stems. The 'fruit' is not a fruit, but the succulent, sweet corolla of the flower, which falls to the ground in March and April. It is eaten greedily by all birds and animals-deer, pigs, cows, and sheepand men. The natives collect as much as they want of it, 
and dry it as an article of food; and a very important article it is, in some districts, saving thousands from death in famine years. It is a crop which is never known to fail, no matter how dry the season. In Central India every village claims its area of mahua-trees, and even in the furthest jungle every tree has an owner, and descends from father to son as a property, on which people marry and live on the value of its product. It is not only the poor man's bread, but his wine. From the sweet stuff, which keeps when dried any length of time, like raisins, the natives distil the mahua spirit in quantity only limited by the duty chargeable to Government. In the Monghyr district in 1873 duty was paid on* I,750 tons of mahua for distilling, and it was proved that, if carefully manufactured, the spirit could be easily freed from essential oils, and made into a most wholesome spirit resembling whisky. But the rum manufacturers of Calcutta and Shahjahanpur petitioned Government, and a prohibition duty was placed on its distillation.

The wild mahua-trees of the Satpuras are very plentiful, having never been cut down or hacked by the natives, and show what the less fortunate timber trees might be if the Gonds had spared them from mutilation. There is another product of the mahua-tree which has been proved to be valuable-i.e., the oil expressed from its seeds. England imports yearly oil seeds from India to the value of five to six millions sterling, principally linseed, but the mahua oil is three times as valuable as linseed, being as good as cocoa-nut oil for candles. Here are,

* Statement of Mr. Lockwood, civil officer of Monghyr, who calculates that each tree produces 2 to $3 \mathrm{cwt}$. of corollas, and that in the 4,000 square miles of his district there were over a million trees, making the yield over 100,000 tons of nourishing food for man or beast. The Santhals, he states, suffer no famines in consequence, and are a plump and happy race. ('Report of the Linnean Society,' 1878.) 
from one tree, forest products of vast importance, which, if exploited systematically, should bring in rast wealth to the exchequer, and afford employment for the poor in their collection.

Even to enumerate all the products of all the trees and plants of the jungle would require a volume. Among them would be included tea, cinchona, indiarubber, gums, frankincense, catechu, and various drugs; wild silks from ten or twelve different silkworms, besides that of the mulberry; rhea* or china grass (which from China is worth $f 60$ a ton as a substitute for silk), lac, and cochineal, which is a red insect found in the forest.

Among the products of trees is oil from the chaulmugratree, $\dagger$ a specific against consumption; thymol; antiseptic kino, from the Butea frondosa; camphor, resin, besides dye-stuffs and tan-stuffs innumerable. $\$$ The frankincense-tree (Boswellia thurifera) grows very commonly on the Mahadeo hills. It has white, pinkish, smooth bark like a naked limb, branches spreading in ungraceful curves with a few leaves at the points, and is tapped largely for its fragrant gum. Solomon sent ships to Tarshish for this product, along with gold, apes, and peacocks. As the Mysore forests produce the whole list to the present day, it is probable that Tarshish was Mysore. The old workings, which have been found 200 feet below the surface in the mines there, are a wonderful proof of the advancement of engineering knowledge in the days of the wise king. We may find that Mysores were boomed and quoted on the Jerusalem

* Made from a kind of nettle, Urtica tenacissima.

+ Gynocardia odorata.

$\ddagger$ See Journal of the Society of Arts, March, I879, paper by John R. Jackson. 
Stock Exchange when dwellers on the Thames were naked savages in dug-out canoes. The champak-tree* grows near the Cave of Mahadeo. It is celebrated in Oriental poetry, and has a sweet-scented flower sacred to the Hindu deities. Sandal-wood, well known in Indian cabinet work, is from a tree occasionally found in the Satpuras, $\nmid$ but more often in Madras and Mysore. Its scent is very familiar to everyone. There is another minor product from the harra-tree (Terminalia chebula), the fruit of which is used for tanning leather.

In the Forest Report, Central Provinces, I898-1899, it is stated that the annual export of harra from these provinces to Bombay is 143,227 tons, and its value I2 annas per maund of 80 pounds.

Bamboos, of which 9,000,000 were cut in the same year, $\dot{\ddagger}$ constitute a considerable article of use. It has been proved that bamboo pulp produces the very best of paper, so that there is an unlimited field for the cultivation and disposal of this easily-grown product. The list of minor products of these forests includes charcoal and grass, which produce annually a very large revenue.

The high plateau of the Mahadeo is a great mass of sandstone rock, lying almost horizontal, but denudated by the processes of nature, which have cut away the softer portions, leaving peaks and precipitous bluffs of quaint shapes, with sudden deep chasms between great cliffs, so narrow that they look as if one might almost step across. Down below are caves dark and unexplored, save by Baloo and Bagheera, overhung by the graceful

* Michelia champaca.

+ Santalum album.

$\ddagger$ Bamboos are floated down to the coast on rafts in enormous quantities, and exported largely. In the teak forest districts the timber, which is too heavy to float, is buoyed up by large bundles of bamboos tied under the rafts. 
fronds of lovely delicate tree-ferns. This is the continuation of the Seoni hills, where Rudyard Kipling has laid the scene of his inimitable jungle stories. Stretching away in the hazy distance one can discern nothing but unbroken forest, range after range of timber-clad undulations, and to the horizon still dense forest.

Beneath our feet yawns the cañon of Andeh Ko. Another crevasse, called Jambo-dwip, lies below Pachmari. To the west lies the Bori forest reserve. To climb down the steep path by a narrow channel cut in the rock is by no means an easy task, but just possible for a hill pony. Elephants, lightly laden with tent and a few necessaries, took several hours in getting down as many miles, holding on like monkeys and balancing themselves on ledges of the steep rock.

We are entering one of those strange depressions, appearing to have no entrance and no apparent exit, which geologists cannot explain. It widens out into a broad valley with almost level bottom, and high walls of rock stand on every side. Lower down a beautiful river of clear water winds across the shingly flats. Here grow large forest trees of great variety and beauty-sagwan (teak), siassa (rosewood)*, saj, bijasal, $\uparrow$ and arjun $\ddagger$ with smooth white pillar-like stem towering to a great height. There are great clumps of feathery bamboos and beautiful groves of sissoo;§ also, standing alone and rising head and shoulders above the others, towers the great semal, || with its extraordinary buttresses. Here is a typical Indian forest, which appears untouched by the devastating hand of man. The complete exclusion of jungle fires, which had

\section{* Dalbergia latifolia.}

$\dagger$ Pterocarpus marsupium, which yields the gum kino of commerce.

+ 'Kahua,' Terminalia arjuna.

$\$$ Dalbergia sissoo.

II Bombax heptaphyllum. 
been successfully carried out for some years previously, certainly showed its effect, as fine saplings, grown from seed, of teak and other sorts were plentiful through the forest. The long grass formed a close covert in the open flats, and wild animals of all sorts lived in peace.

This forest took a long time to inspect, and days were spent just wandering through the reserve, which was pretty extensive, and climbing the heights, sometimes on an elephant, sometimes on foot; always accompanied by old Boodoo and the forest jamadar and some watchers, of whom there was a good staff, and whose business it was to clear the great open line, which had been cut in a complete circle all round, of weeds and jungle grass, which would otherwise carry the jungle fire into the sacred precincts. To describe the numerous encounters with every sort of wild beast would be monotonous, but I will just endeavour to picture one day. At dawn a faithful makhna (tuskless) elephant, called Malunga, is kneeling at the tent door while the pad is being 'kinched.' Malunga is a good steady hati about Io feet 6 inches high, a very tall, long-striding, active, and sensible beast, belonging to the Forest Department. The Duke of Connaught rode him when the great hank took place in these hills. A chaprasi holds up the big, ever-moving tail, on which a foot is placed as a step to clamber on to the pad. Mail is elephant language for ' march,' which Malunga proceeds to do, having elevated himself off his knees, a process which obliges the occupants of the pad to hold on hard by the ropes. We are going up the valley, crossing a series of jungle-clad slopes on the left of the river, and inspect the land for timber trees. Silently and smoothly, but with a rocking sway, Malunga forges ahead, his mahout guiding him gently by touches of the great toe in the back of his great floppy ears. Thick bamboo jungle 
and fine young teak-trees alternate with bare grassy patches.

We cross the river, and meet at the three semal-trees half a dozen Gonds and watchers, who have been sent on by Boodoo. We begin to ascend the opposite hill now on foot, as it is too steep for an elephant. Here are fine trees of all sorts; and, gaining the heights some $\mathrm{I}, \mathrm{OOO}$ feet above the valley along a regular bison track, we wind in and out among ridges and rocky valleys. Boodoo is anxious to procure a specimen of the great gaur or bison, and points to the fresh tracks on the path of their great broad, horny feet, and the top shoots of shrubs freshly nipped off and thrown on the ground. They point towards the ghat which leads to another watershed, with valleys sloping away to the south. The sun's rays are now hot, and the breeze comes up the valleys. I am placed on the ghat concealed among rocks, while Boodoo takes his men a circuit in the valley, hoping to head the herd of bison and drive them back over the ghat. Alas for the uncertainty of events; there is with the bison an elephant which has escaped from captivity! The bison have good noses but small ears. They cannot hear sounds so well as an elephant. They keep together for mutual advantage, and hati is breaking down bamboos with his trunk for the gaurs to browse upon. I can hear the cracking not far below the ghat. Presently there comes one of those curling winds called 'devils,' moving against the breeze down the ghat. There was a rush through the brushwood, the rattling of stones, the noise of many hoofs stampeding, and the trumpet of an elephant. The clever big brutes had scented the presence of white men, and were rushing, not up the ghat, but down and away. Boodoo shortly returned, having seen ten fine gaurs and a small elephant pass him within a few paces. The same 
evening, when returning down the valley, crossing ridges among heavy timber, with Boodoo leading, we started a sambur stag. He rushed across the hollow and stood on the next ridge listening for a moment, affording me a nice shot behind the shoulder with the I4-bore rifle. He fell to the shot, and never moved. This was the finest sambur of my bag, 42 -inch horns, 4 I-inch spread, $8 \frac{1}{2}$ inches round the beam, a very rare size.

I had two German bloodhounds (schweiss-hund), called Hirschman and Hela, brought from the Harz mountains, which became very useful for tracking deer. Fastened by a leash, one of them would follow on the line, carefully nosing the ground where a wounded buck had gone, and pulling hard to get on, old Boodoo holding the strap, for long distances. Boodoo trusted his own tracking far more, and did not believe in scent, which he did not think much of as dogs in India run by sight mostly.

When riding an elephant in the open sal jungles below the Bori forest, I had the unwonted fortune to meet and shoot a very fine specimen of the big swamp deer or barasingha, with I2-tined horns and about the size of the sambur. He stood for a moment gazing at the elephant in an open glade, his great, wide-spreading antlers resembling Landseer's picture of the red deer on the hill.

The next visit to the Bori forest was to collect timber for building, and to explore a fine sal forest lower down the valley, where great stems roo feet high and 8 feet in girth existed; but these rare and useful trees grew in land belonging to a Rajah. Anyone might easily tell Government forest by the big old trees having all disappeared.

I was crossing one day an open space in the Bori valley 
near the river, where low jungle grass grew, all yellow and dry, when, as so often happens in Indian forests, I had a surprise and experience quite new. Shikaris had often spoken of the sone kutte (wild dogs), which hunt in packs and drive every kind of game clean out of the jungle, never leaving the doomed victims of their persevering pursuit till death puts an end to the chase. I had never come across a pack of wild dogs, though I had heard from the natives of their presence both in the Himalayas and in the plains, during an experience of eight or nine years, and I had met no British officer who had actually seen a pack hunting.

It was therefore a matter of great interest to see, from the elephant which I was riding, a whole line of red dogs, about the size of harriers, but with more the appearance of wire-haired, prick-eared terriers, regularly drawing the covert in front of me. They have rufous-coloured backs and hairy sterns held straight out like a fox, which are easily seen just showing in the thick grass. They were beautifully fanned out across the covert, and a few watchers were stationed at its end, like whips, to tally the game away. Occasionally one or two would sight some animal, perhaps a small deer, and they would bound in the air to view over the top of the feathery grass. They got on the line of something, and ran it out at the end and across the bed of the shallow river, disappearing into high jungle at the other end ; but they ran quite silent, giving no tongue. I followed on rapidly, but lost view of them after they crossed the river. They were about forty in number, and all alike, a hungry-looking, black-nosed, active pack.

My tent was pitched close to the river on the flat. Sitting at night outside the tent by a pleasant fire, I heard strange sounds in the jungle. First the belling of a 
sambur stag, loud and sonorous, from the hill above the valley, answered by other calls; then the dismal howling of the gidar log (jackals). Boodoo, with ears on the strain, sat smoking his hubble-bubble (a cocoa-nut with a bamboo mouthpiece), wrapped in his only garment, a black blanket. Among the many animals there was khabar (news) going round, 'Sone kutte ai gia!' ('the jungle dogs are here!'). The old jungle man could read and interpret what each warning note signified. Peacocks roosting in the tall trees craned their necks and could not sleep, uttering a sharp 'Ping!' and occasionally changing their position to a higher perch. There is a hollow vibrating sound in the air, coming first from one direction, then from the opposite side. Boodoo pointed to great rocks cut sharp against the sky: 'Bagheera' is there watching, the skulking panther; "Baghi' the tigress is calling to her cubs to hasten-' $\mathrm{a}-\mathrm{i}-\hat{\mathrm{a}}-\mathrm{o}-\mathrm{u}$ ' (with the accent on the a) is her hollow, deep drawn-out cry. 'Sone kutte ai gia!' it all means-' the plaguy red dogs are on the trail hunting. It is time to clear out of the Bori jungle.' There are noises of the rush of a herd of frightened sambur on the hill high up, and the rattling of stones. Even the big heavy bison are on the move for quieter quarters.

We are wakened several times in the night by splashing in the river bed or the snarl of our dogs tied in the porch of the tent. The morning star, by which Boodoo tells the hour, has risen over the hill, and is now fading in the dawn of approaching day. His shiny face, with its black, snake-like locks, round which a scanty dirty rag is wound for the sake of manners, is put in at the tent door : 'Sahib, sahib! sone kutte ai gia!' At the same moment the rush of an animal is heard at the river bank, and the air is filled by the most unearthly shrill squeals, piercing, and followed 
by a short, sharp bark and another chorus of squeals.* 'Jaldi, sahib-Jaldi!' ('haste, haste!'). We rush out, and, carefully advancing through long grass, approach the bank of the river, shaded by great trees. There is just daylight enough to see a sight which is given to few to see, the death of the hunted stag, which has been chased by forty hell-hounds for perhaps days-a noble beast, which has used every wile in vain, and has been fairly run into in the bed of the stream. He is at bay in a deep pool, and has tossed several on the points of his horns ; but there are others, which press on him from every side, and fasten on his cheek, his neck, and hind-legs. Their jaws, once locked in a vice-like grip, never let go. The unequal struggle soon comes to an end, and the stag falls at the river-bank to rise no more. Then ensues a general mêlée, and every hound, with red tongue hanging out, panting and snarling, rushes in to take his share, not very particular whether he gets hold of a haunch of venison or a piece of another hound. The fight once begun and blood drawn, there is vengeance and fratricidal war, when suddenly the report of my rifle rings out sharp, and the fighting ceases. Another shot at a big sentinel dog which has been sitting on the top of a rock, coolly licking himself, and watching us without a particle of alarm. He falls from his perch, and another dog takes his place. This gentleman looks as if he was a good deal annoyed, and the red hair bristles and stands on his back. He has no idea of running away, but looks a warning to us to come no nearer. The death-worry still proceeds, and little is left of the stag. I fire another shot, and Boodoo advises caution in approaching till the orgies are complete, as he declares that if enraged the pack will attack us.

* It has been recently stated in the Field that these dogs are mute, but I will vouch for the above. 
They finish their meal, and deliberately, without hurry, disperse, leaving some of their number dead or badly wounded among the rocks. It is not wise to go too near a wounded dog; but at length we gather the spoils, two good specimens, male and female.

I am very much pleased at securing these rare animals, and trust the taking off the skins to no native skinner, but skin them carefully myself.* For some time all game seemed to have left the Bori forest, but this was the last I saw of the pack. The amount of destruction wrought by a pack of fifty or a hundred sone kutte among the game of the forest must be considerable, especially among the deer, which seem to be their principal quarry. But the Gonds declare they will hunt and pull down any animal, even to the lordly tiger. I have not heard of their killing cattle, but they can tackle nilghai easily, and pigs are their prey, and chital. The battle of an old boar for his life must be a fierce and bloody affair, as his tusks are very sharp, and he can use them. As one does not hear of the wild dog being often shot, it seems likely that they would increase in numbers rapidly. But they remain rare animals, from which it might be argued that a good many are killed by boars or tigers in deadly fights. They are certainly brave in their combined attack, and seem not to fear even man.

There are several quaint old coloured prints in that most fascinating book, Williamson's 'Sports of the East,' published a century ago, depicting the attack of wild dogs on a tiger; showing that the Anglo-Indian sportsman of those days-who is represented hunting in a top-hat-was

* These skins were set up by Rowland Ward in a large case, which was exhibited at two Indian exhibitions in London and the South Kensington Museum, and is now deposited on loan at the Natural History Museum in Dublin. The wild dogs are fighting over the head of the sambur. 
familiar with the sone kutte. They are drawn much too smooth-coated and not red enough, but otherwise about right. By-the-by, the artist who drew the wild buffaloes could never have seen one, as he makes the horns to curl back like those of an ibex. When a child, I remember well taking immense delight in that old book, which was kept on a shelf and only shown as a great treat to extragood boys.

The hunting instinct is easily developed in the youthful mind by such books; and that a period comprising ten years of my life was spent in the forests of India, in immediate contact with nature in its most interesting and wildest phases, had something to say to the pictures in Williamson. The books of Catlin, and, later, Gordon Cumming,* assisted in stimulating the taste for hunting, which, combined with a love of plants and trees, conspired to make practical work in the forests most fascinating. That such was my lot I can never regret. That it was cast under the guidance of old Indian officers in times when the services could still boast of such names as Lawrence, Colvin, Drummond, Dalhousie, and, not least, Ramsay, I look on as a great honour. That the love of the chase is compatible with perseverance in sterner work I have proved. That nothing but benefit to mind and body accrues from enthusiastic participation in the chase, even the more artificial one of the fox, I am firmly convinced. Young men who have to fight the battles of their country can have no better training than the chase, to knit the muscles and develop them to the best

* I have not visited that former paradise of hunters, South Africa, but I have hunted the bison of America when millions wandered over its vast prairies, and $I$ have shot the great wapiti stag in the Rockies, and the big-horn ram, which comes very near the Ovis Ammon, so that the interest awakened by those old books did not completely languish. 
advantage, to train the eye and mind to quick sympathy and action. The love of the chase and of horses, acquired in the saddle, is certainly to both youth and maiden an exhilarating, health-giving passion, and to those advanced in years it is an abiding source of interest and a rejuvenating influence. To those who would choose a career of usefulness, where earnest work can be relieved by active and wholesome recreation, I can recommend no service more suitable than the Indian Forest Service, one full of interest and of great promise for the benefit of mankind in future generations. I must not conclude these recollections without doing honour to the name of one to whose scientific and untiring energy the Government of India is indebted for the establishment and organization of its Forest Departments on the best principles ; I allude to Inspector-General Dr. (now Sir Dietrich) Brandis, under whom I had the pleasure of serving. If from unavoidable circumstances connected with ill-health I was obliged to terminate my connection with the Department sooner than I otherwise should have done, just as I was getting into the swing of executive forest work, I can only say that the loss was my own, and that such things are unavoidable. But I can look back with sincere pleasure on the ten years of my service, and can believe that I shall never spend happier years than those which I had the good fortune to spend in the forests of India. 


\section{APPENDIX}

\section{ON THE SCIENTIFIC MANAGEMENT OF FORESTS}

ON my taking furlough in Europe, after seven years' employment in India, I received permission from the India Office, on the recommendation of Dr. Brandis, to go through a course of instruction in Hanover. Having spent some time there, receiving lectures and practical instruction, I had the good fortune to accompany the Inspector-General on his annual tour of inspection through the Harz mountains. We drove in a carriage and pair The Harz. for miles by smooth roads, which wound upwards among endless groves of pines, ${ }^{*}$ in squares of different ages, standing as close together as they could stick, all planted in rows. Every row was as straight as a line, vistas running forwards in endless perspective, left and right, as far as the eye could reach. What a revelation to one direct from the Himalayas, where no two trees are of the same kind or the same age, and all are located by chance, as Nature sowed them. This was the Harz forest, the birthplace of forest lore.

The country was divided like a chess-board into rezier (districts), each under its separate officer and management. A Hochwald-betrieb, 'highdistrict is roughly $\mathrm{I}, 000$ morgen, or acres. The rotation prescribed for trees like spruce is roo years. The district is divided into ten stripes, or squares, corresponding to each decade of the century, during which period the proper square or stripe, where the oldest mature trees are, is felled and disposed of, and the 100 acres involved are replanted in rows, each row and each tree 3 feet apart. There are nurseries for seedlings, whence the planting out is done. The decade is again subdivided, so that 10 acres

* Fichten and Tannen. The abies and picea of Europe, spruce and silver fir, which make white deal, corresponding with Abies Smithiana and Picea IVebbiana of India. 
Rule of thinning.

Protection from wind.

Rule for production of timber. are cut down and 10 acres replanted each year. Thus, at the end of the century every square has had a full crop of mature timber taken off it and been replanted with a new crop. The rule for thinning, which is also carried out at stated periods, is to cut out the overshadowed stems. Thus, the surviving trees are chosen by natural selection, and the master trees only remain. The heads of the trees are always seeking the daylight, and thus the most rapid lengthening out is attained, and the side branches are crushed and drop off as they decay, leaving a straight-grained tree, free from knots. Thinning out is then performed, to let in air and light and promote the thickening process. The sale of thinnings pays all the expenses, and at the end of the roo years the ground carries from 100 to 150 mature trees to each acre, of a value of, say, $\mathcal{E}_{\mathrm{I}}$ per tree.*

The rent of this land for grazing might be about $5 \mathrm{~s}$. yearly per acre, so that from one acre of forest there is a revenue of over $\mathcal{E}_{\mathrm{r}} \textrm{ } 00$ in 100 years, or $\mathcal{E} \mathrm{I}$ per acre yearly instead of $5 \mathrm{~s}$. There is an important consideration always to be acted on-that of the effect of the prevailing wind. The tallest trees must always have the next tallest plot to windward of them, to protect them from the storm; and so the plots are arranged in steps like stairs, each older lot being guarded by a younger lot, while the youngest lot is sheltered by the oldest of the next series of steps.

There is another important consideration in a 'working plan' recorded in the books, with dates and areas of cutting and planting prescribed for all time to come : that, at the end of any rotation period, the capital value of the stock-in-trade-i.e., the growing timber-must be fully maintained, or even improved, so that the annual yield, representing the interest of that capital, is a source of revenue as regular as clockwork to the State which owns the forest. The rule is that the zuwachs, or growth of timber of the district, must never be outstepped by the benützung, or yield of timber.

In private forests, and those worked under the system adopted in Great Britain and her colonies, the end of a working period is often the end of the forest. Interest and principal are generally gone, or in the more favourable cases the stock is deteriorated by

- It has been found that land that is not worth more than 8s. per acre for grazing will pay far better to plant. 
want of supervision and foresight, until practically nothing is left of any market value or benefit to the country. It must be so, because generations of men are much shorter than the lives of trees. Therefore forests will never be managed to the advantage of the country except by State regulation. The Virthschaft Plan, or 'working plan,' is the keystone of forestry, and without this foundation everything is haphazard and futile.

The perfection to which forest management is brought in the Harz mountains is most striking. Every plot of land has its place in the general scheme, and everyone knows what is to be done next. The healthful, muscle-producing employment given to a large, thriving population is a source of great strength to the country, and exactly the right quantity of timber and firewood is produced on the spot to supply the market, which is not flooded at one time and starved at another. Such is a forest district 'working plan' on the Hochwald principle, as found to perfection in Germany.

I had the honour of reading a paper on Forestry before the Society of Arts in 1872 , in which I strongly advocated the adoption in England of scientific forestry. The discussion which followed showed that the learned disputants had come there to air their eloquence, not from interest in forest culture, but in opposition to its introduction into Crown forests; and that by forest principles they meant the rights of owners of pigs to graze them in the New Forest, and of every man who lived near to carry away top and lop for firewood.

It is strange that the British people, so shrewd and enterprising in trade, seems never to look further ahead than what concerns each man's own immediate profit. The manufacturing classes, to inflate their own gains, have selfishly eaten up the landed interest and impoverished the agricultural class. The mining classes are frantically engaged in exhausting the mineral stores of Nature. We English have destroyed the fine forests once covering our hills, and are blind to the fact that hacking down the trees (to which, in the colonies, is given the significant name of 'lumber') all over the world, and planting none, means timber famine in the future. Experts declare it a very near future. Yet not a move has yet been made by the British Government to restore British forests or educate foresters scientifically, and it is only at the

Forest princi-

ples misunderstood in England.
British want of foresight and selfishness. 
expense of the Indian Government that a solitary forest school has been established in England.* "But land legislation in Ireland and succession laws have been recently framed so as to

British legislation destructive to forests.

Loss of carbcn in England.

Warnings given by forest experts. protect the few private forests in the country?" No, not at all; rather to place a premium on their destruction. All other countries in Europe have taken the forests under Government management. Germany and France have many forest schools. England alone has done nothing. Immense wealth may be extracted from coal-mines and gold-mines, but when they are exhausted they have no recuperative power, and the mining population must perish out of the country. But forests, if planted, will always be growing and extracting carbon from the air for future use, which carbon is essential to man. Millions of tons of it are being dissipated and wasted in the form of carbonic oxide from coal consumption, at a pace which must bring it to an end in England within a measurable distance of time.

In this matter, as well as in trade, Germany and other countries are steadily taking up the advantages for the future which the British throw away. In Dr. Schlich's 'Manual of Forestry' there is a table (p. 54) which shows that the percentage of forest in Germany is 0.26 of the whole land, while the British Isles have only $0^{\circ} 4$ per cent. Russia has $0^{*} 42$, Sweden $0^{\circ} 35$, France $0^{\circ} \mathbf{6}$, Norway 0.25 . These enormous forest areas are drawing from the air the carbon which is being lost to England by coal combustion, lost irretrievably to us. Enormous areas in England and Ireland are lying practically waste, which might grow the finest of timber and recover a share of the lost carbon.

The journal of the Society of Arts in London records no less than seven most interesting and authoritative papers on Forestry in recent years, $\dagger$ each of them describing the fatal progress of forest destruction wrought by the Anglo-Saxon race in the last thirty years, and strongly urging on our Government to follow the example of other nations before it is too late. At the meeting of the British Association at Oxford in 1894 Professor Bayley

* At Cooper's Hill. There is also a lecturer at Edinburgh.

$\dagger$ 'Papers on Forestry,' by Colonel Wragge, December, I\$7I ; by Sir R. Temple, January, I88I ; by Colonel Pearson, March, I\$82 ; by P. L. Simmonds, February, I885; by Dr. Schlich, February, I890; by General Michael, December, 1894 ; by D. E. Hutchins, November, I899; and Dr. Schlich, I90I . 
Balfour delivered an address on forests, in which are these words: 'That the possibility of forest exhaustion is no chimera should be evident to anyone conversant with current timber literature.' The address shows that in the Baltic States, whence most of our timber supply comes, the virgin forests are practically exhausted, and both Sweden and Norway have begun importing from America. 'But it is not only in Northern Europe that there are signs of the giving out of timber forests'; Canada will soon be scarcely able to supply the American demand, and the United States Official Department of Forestry report for 1892 stated that 'the end of the whole supply of both Canada and the United States is now plainly in view.' This was ten years ago, and since then things have got worse. There has, however, been a start made in some British colonies. In Cape Colony a Forest Department has been established. Forest organization was started in Natal, but allowed to collapse, so that three-quarters of its fine indigenous forests are destroyed. The kauri forests of New Zealand, uniquely magnificent, have been wantonly devastated, and the splendid jarra forests of Australia* are being rapidly used up in the paving of London streets, to make the fortunes of men who never planted a tree.

The able paper on National Forestry by D. E. Hutchins, the enthusiastic Conservator of forests of Cape Town, read before the Society of Arts in November, 1899 , sets before the public some curious facts. The timber which Britain buys every year from abroad, to the value of $£ 20,750,000$, could be grown in England on land which now produces almost nothing, bare bleak moor and mountain, where the soil is getting more and more washed away for lack of shelter. The interest of the National Debt is 25 millions, which could be paid out of the profits of the forests if they existed Profitable into the extent of one-tenth of the surface. Germany has one acre of forest to every three. England has now only one in every twenty-five, and that one acre only third class, badly managed plantation. The plantations of England can scarcely count as forests, as they are not managed on any plan, and are liable to be worked out of capital, or cut down at the caprice or necessity of

* A Forest Department has been lately started in New South IVales and Victoria, also in South Australia and Tasmania, which it is hoped may save these forests from complete destruction. 
Provides employment

and military material.

Improved climate. private owners, besides being taxed so heavily for succession duty that owners are forced to cut them. England is at a loss of over 25 millions annually in forest products; and not only so, but she has lost the entire capital which a well-stocked forest represents. In other words, if English waste lands were fully afforested, the capital value would be about 200 millions. The capital value of German State forests alone is 900 millions sterling. *

Further, the loss to the country is enormously greater, if the employment which would be provided in the production of homegrown timber is taken into account. As in Germany, a population of well paid and hardy forest workers would be maintained in the State forests free of cost to the nation, available for military service, equivalent to the entire present British army, which costs the country 30 millions annually, and in peace-time can perform no productive labour. $\dagger$ Thus, if British statesmen were to take up the matter of re-afforesting on the same lines as the State forests of Germany, the money invested by the State (say I million annually for the first thirty-five years, after which the forests would begin to pay) would become a source of certain and ever-increasing profit to the State, and also save the taxpayer vast sums, and solve the great problems of rural population and army organization.

There is another advantage of having waste lands all over the country planted: that the temperature of well-timbered countries is less subject to extremes of cold in winter, also that the roots of trees dry up swampy land and moisture becomes less excessive. And, furthermore, that a country which is supplied with belts of timber is in time of war incomparably more easily defended than an open country. And, by having State forests in the neighbourhood of large towns, the poor people would have the advantage of healthy air and sylvan recreation-grounds within easy reach of their dwellings, which private parks do not afford.

* See Professor Hutchins' paper ; also 'Manual of Forestry,' by Dr. Schlich.

† In the 'Manual of Forestry,' Dr. Schlich calculates (page I I4) that when the proposed area comes under forest management the State will be employing 100,000 forest labourers, men used to hard out-of-door work. These would form a military reserve worth, for fighting, double the number of factory or town-reared soldiers. Forest industries would employ four times that number. In Germany about 12 per cent. of the population are employed in forest industries.

$\mp$ See experiments made in Germany, by double stations of observation in forest and open land, described in Professor Schlich's 'Manual,' page 32. 
It may be asked where the land to plant is to come from. The reply is easy.

Out of 56 million acres in Great Britain, there are only 16 million Proposals to re-afforest England and Ireunder crops and 16 million pasture, leaving a balance of 24 million acres of waste mountain, heath, and moor, a good deal of which is of small economic value, and admirably suitable for timber growing. In Ireland there are 4 million acres under crops, I I million pasture, and the balance of 6 million is almost all barren bog and mountain. According to the Recess Committee, 3 million of these are available for planting. Mr. Hutchins puts the amount of forest to be taken under State management, in order to supply timber at home, as 9 million acres. Dr. Schlich puts it at 6 million for the three kingdoms, which would leave ample areas for sheep-grazing, which the importation of frozen mutton renders less profitable. Sheep land gives employment to perhaps one shepherd on I,000 acres, which, if under forest, would pay four times the present rent, and give employment to a very large population.*

Land which is so poor in quality as to be almost worthless for agriculture, will grow very fine timber. Chemical research has shown that the mineral and chemical constituents in the soil required to grow an acre of field crops is $235 \mathrm{lb}$., while on an acre growing trees for timber, only i $9 \mathrm{lb}$. is required yearly. Of the substances potash and phosphates, trees require one-twentieth only of the quantity required by field crops (Schlich's 'Manual,' p. 200).

It may be asked, How is the State to find the one million a year which, according to Mr. Hutchins' scheme, is required to plant the proper amount of land-300,000 acres yearly-to rehabilitate the forests? The reply is, In exactly the same way that money is found for any other profitable investment; but as the State will be the ultimate gainer both in annual revenuc and the building up of an enormous property of immense capital value, which individuals could not live long enough to profit by, so the State, which can borrow at the lowest rate, can with advantage find the money. This is not only perfectly sound finance, but it is an imperative duty of the State, which will have to be performed sooner or later, as timber from abroad comes to an end. It is

* The chair-making industry in the beech-woods of Buckinghamshire employs 30,000 people. 
significant that the consumption of timber in England (and in America also) is increasing yearly at a regular and rapid rate, while the sources of timber-supply are getting rapidly fewer. But if England can save a pound by laying out a shilling she will not lay out that shilling until absolutely compelled; and for this style of economy, or want of economy, called 'drifting,' the politicians who opposed the scientific management of the New Forest, and allowed its magnificent old trees to be lopped and burnt by the commoners, are mainly responsible.

That England does not possess one single forest managed on any plan of rotation* similar to the ordinary 'working plan,' under which all the Continental forests have been brought to their present condition of regular productiveness and renewal, seems almost incredible. Yet it is a fact that none existed where the pupils of the Indian forest-school could be trained in the practice of forestry, and until lately $\dagger$ they had to go through the course in Germany or France.

Timber of the qest only grown by proper management.

British climate and soil ideal for timber growth.
It has been objected that the timber grown in England is inferior to foreign-grown pine and deal, so much so that in Board of Works contracts home-grown timber is unpatriotically excluded. On this point anyone who has studied the growth of pine-trees in the natural forests of the Himalayas and the Rocky Mountains can easily see that the inferiority of much plantationgrown timber is due to the ignorance of those who planted the various kinds of pines in the wrong positions, and also to its being grown too fast and coarse in the grain.

The mountains and moors and waste lands of Scotland, England, Wales, and Ireland have a climate and soil quite ideal for the growth of larch, spruce, and pine timber, if care is taken to treat them according to Nature's laws. Scotch fir, as grown in plantations, is perishable, loose-grained stuff, entirely unfit for joiners' work. This is timber grown wrongly. But in the bogs in Ireland, lying under 20 feet of peat, are found Scotch fir stems of great length and thickness, which may have lain there 10,000 years, the timber of which is perfectly sound, fine-grained,

* Within a few years three or four private owners have had "working plans" constructed.

T A strip of Windsor Great Forest has now been granted to the Cooper's Ifill College, which will be brought into rotation in a century to train the pupils in 
heavy, solid, and straight, and so excellent that it is used by coach-builders as superior to Memel or the finest mahogany. I have measured the butts of such trees in situ which girthed 20 feet. It is the age, method of growth, and proper position which make the sound close-grained timber. In the Black Forest there are some rocky hillsides specially planted with common fir, grown How valuable fine-grained timber can be close together in a dense grove, very tall, and with no side branches. These trees, from the rocky nature of the soil and the northern aspect, have taken perhaps 150 years to grow a couple of feet thick; but the grain is close and fine-like box-wood almost-and the timber is worth nearly its weight in silver for making sounding-boards for violins and pianos.

The great industry of splitting spruce into thin sheets for making band-boxes, which employs thousands of people in Germany, is dependent entirely on the timber being suitably grown, which is as easy as can be when you know how.

It can be seen that forestry is not merely learning to handle an axe and spade, or to plant trees by rule all alike. Amateur planters of trees for ornament, and private owners of forests or woods in England, where every man is free to do what he likes with his own, can in the nature of things know or care very little about the economical production of timber for the use of the country in time to come. Growing wheat in a flower-pot in a greenhouse is not the same thing as growing wheat for the market on the most approved agricultural principles. Yet this has been very like the old-fashioned English system of timber-growing recommended in Brown's book, and is not correct forestry. And it is certainly the function of the State to own and manage the forests of Great Britain, as done by every other Government in Europe.

In travelling through Canada anci the North-Western States, where recently the country was one vast forest of magnificent trees, which had taken centuries to grow, one now sees nothing State forestry the proper remedy. but charred and blackened stumps; and the annual forest fires destroy timber in a few days worth hundreds of millions, while nothing is ever replanted. The very valuable so-called Spanish mahogany, which used to be imported from the equatorial regions of America, has almost ceased to exist, so much so that old Chippendale furniture is considered, from the excellence of its old dark timber, more solid and durable than modern-made

Destruction of forests on the American Continent. 
Instances of decay of countries where the forests have been cut down and fertility of the soil lost. mahogany furniture. The recently imported mahogany is quite inferior, simply because the old trees were recklessly felled, and no renewal of the forest attempted.

Spain is a country which once was covered with the finest oak, pine, and chestnut trees. Now one may travel through Spain and see nothing but stumps, from which the branches are cut yearly for firing, or bare mountain sides, scorched by the sun, and with the once fertile loam all washed away by the rain, till nothing is left but sand and rock. The extremes of heat and cold are thus accentuated, as well as the extremes of drought and flood, which are necessarily excessive in a treeless country. The people are badly clothed and fed, and the houses built of cold stone, as timber is almost unprocurable. Such is the condition of a country where the forests have been exhausted. Italy and Sicily (where Hiero once built his 4,000-ton ship), celebrated for their forests and their navies, and also Greece, are in similar plight, and are reckoned among nations once the most powerful and prosperous, now fallen from their high estate and reduced to extreme financial distress and almost to decay; and their people are, in unfavourable contrast with those of Germany and France, the most struggling, overtaxed, and poverty-stricken peoples in Europe.

England relies on her maritime position and commercial prosperity exactly as these countries did, which makes it easy at present to import the timber and other articles of consumption and food that she requires rather than grow them at home. History relates how countries which have relied on such facilities and neglected to keep up home production, but permitted the soil to lose all the shelter that Nature gave it, have inevitably fallen from prosperity sooner or later. This is a reflection that is worthy of the attention of England's statesmen. Already the agricultural population, the backbone of a country's defence and prosperity, is in a very sorry condition; and in Ireland there is a perpetual sore.

The tendency of countries to fall from their pristine state of fertility and consequent prosperity when the forests which clothed and sheltered the surface have been tampered with is further exemplified by the present dried-up condition of Rajputana and Sind. Famines in India are due to forest denudation. The ancient writings of the Ramayana show that these countries were once 
covered with forest and fertile, though now dried-up and desert. The same story is told of the region of the great Assyrian Empire, once flourishing, now fallen to decay. Beneath the drifting sands of the Gobi desert Dr. Sven Hedin discovered the dwellings of a teeming population, whose cities, built of timber, stood on a fertile and well-watered plain. Now a few tamarisk bushes alone are found half buried in the dunes, and the great rivers of the central plateau are lost in ever accumulating and ever drifting sand. The absence of vegetation reacts on the climate, and the dry climate reacts on the water-supply, until absolute desert is the result.

Such a catastrophe is not likely to happen in the British Isles, where the moist airs from the Atlantic assist vegetation; but, in a modified degree, the loss of shelter occasioned by absence of timber and the baring of the soil to the vicissitudes of climate must cause a great loss of fertility. Even close to the sea, in the Landes, a great area of Southern France was becoming a desert until it was planted with Pinus maritima.

The same treatment of immense areas of waste land reclaimed from the Baltic in the Heide of North Germany, where Scotch fir timber is grown now to the value of $£$ roo to the acre, is another remarkable instance of the success of State forest culture in restoring the forests and protecting the soil, whereby the climate is beneficially affected.

The lessons to be learnt in the matter of forest culture from observation of Nature, which assist the forester to arrive at the most economical and successful methods of growing good crops of timber, are worthy of attention.

First, as to the position, aspect, and soil which suit the various kinds of trees, Nature makes an invariable rule that, wherever the proper conditions exist, there the suitable kinds are to be found, and are sure to flourish. For example, in the Himalayas the southern sides of the ranges are clothed with oaks and deciduous trees. On the northern slopes are silver fir and spruce, while the lower sunny slopes are covered with the heat-loving Pinus longifolia, not mixed or jumbled up anyhow, but each separate species in its own legitimate place. We do not see the wrong species planted in the wrong place, with the invariable result - unhealthy trees, stag-headed, decayed at the roots, and

Lessons from observation of Nature in undisturbed forests.

Nature selects the suitable position. 
Natural distri. bution of trees of all ages and in groups.

Calamities of fire remedied by Nature.

Great age of naturallygrown timber. prematurely aged, while the timber is badly grown and worthless, as in British-managed plantations.

In Nature we find all ages growing together on the same ground, but mostly groups of different ages, according as the seedlings have sprung where the seeds fell from the parent standards and were scattered by the wind. Thus the saplings have been forced up tall and straight in clusters, and never thinned out at all. The stronger individuals overtop the weaker and crush them, when they die and wither, not seeing the sky. This secures straight, clean boles, free from knots; and all the trees remaining to grow to maturity are master trees, not weaklings. The result is slowly grown, sound timber, very different to the quickly grown, coarse, and unsound stuff found in mixed plantations, which have been thinned out as if carefully to secure branching heads and the most rapid and unhealthy increment.

This is the normal method of renewal, and the almost universal one; but as amongst human races calamities may come and sweep away the whole population, so an entire forest may be burnt down. This is a very frequent occurrence in the Rocky Mountains, owing to the climate and the negligence and interference of men. Nature provides even here a remedy. The seeds which have remained in the ground begin to germinate when they get the sun, and a complete new crop springs like a carpet from the soil. Whether the seed always remains in the soil or is transported from adjoining forests by the wind is not determined, but I have seen the process going on over large areas of spruce and silver fir and pine in the Rocky Mountains, the seedling trees springing up amongst the fallen stems of the previous growth so closely together (twenty or thirty to the square yard) that the thicket was absolutely impenetrable to man or beast. Such self-renovated forests are abundant in Western America, and are easily known by the age of the trees being all alike. They produce the most excellent timber when of mature age. The tall trees stand like pillars, perfect cylinders, without branches, though never thinned by the axe of man. Such timber takes a long time to mature, and is of the best quality.

In Corsica, where some pine forests have escaped destruction from their inaccessibility, there are still some trees, said to be 
hundreds of years old, of magnificent proportions and excellent quality. In California the great sequoia-trees of Mariposa are computed to be 11,000 years old, and in Japan the cryptomerias are of immense age. In India I have seen cedar-trees (deodara) 40 feet in girth and $25^{\circ}$ feet high, the age of which must be 1,000 years or more; and the mature spruce, cypress, and silver firs of the upper Himalayan forests, judging from the number of their rings, are often $35^{\circ}$ years old. The chir and other indigenous pines are not found so old, but I have counted the rings of many first-class trees and found them all over $\mathrm{I} 20$ years, and often 260. In fact good timber cannot be grown rapidly.

The length of forest rotations proved by experience to be correct in Germany and France varies, according to the capacity of the soil for growing the best construction timber or inferior prop-wood or firing, from 250 to 70 years. The oak and beech forests of the Spessart have a rotation of $25^{\circ}$ years for the oak and half that for the beech. The Hochwald systems in Germany and France have rotations of from 100 to 120 years, while the inferior lands, which grow coarse timber, are worked on the lowest 70 years' period. In the common or village forests, which are under State management, 70 to roo years is prescribed, as only farm timber and firewood are grown.

The quantity of timber which can be produced on the ground in a properly managed forest may also be learnt from Nature. I counted for years the trees per acre growing in the Himalayan natural forests. The average of one kind over considerable areas did not come to more than thirty trees per acre, owing to the conformation of the hills and the patchy reproduction of each kind ; but on suitable hill-slopes, where the spruce and silver fir occupied the soil, I often counted roo first-class trees growing on an acre, besides all the saplings not counted. These were truly noble giants of the forest, ranging from trees over 6 feet in girth to older patriarchs of I2, and 200 feet high; having never been thinned out, the stems were free from side branches for roo feet. The amount of the timber of the highest quality on an acre could not have been less than 20,000 cubic feet. This in forest where there was no management at all except that of Nature. In Hochwald forests, managed scientifically, Dr. Schlich* states that the

$$
\text { * 'Manual of Forestry,' page 22б. }
$$

Quantity of timber carried per acre.
Lengths of rotation deter. mined. 
average growing stock in a first-class forest in Germany has been found to be on a fully stocked acre of-

$\left.\begin{array}{llllcc}\text { Silver fir } & \ldots & \ldots & \ldots & 17,400 \text { cubic feet } \\ \text { Spruce } \ldots & \ldots & \ldots & \ldots & 14,500 \quad, \\ \text { Scotch pine } & \ldots & \ldots & \ldots & 9,780 \quad,,\end{array}\right\}$ Age 120 years.

and he points out that where an acre is calculated to produce roo trees, after all thinnings are over, these will thicken and mature to an average of 100 cubic feet each in 100 years-that is, 10,000 cubic feet per acre. There are miles and miles of forests in Germany which, when mature, will yield this steady average, though, of course, on inferior soil the crop will be far lighter. How many acres of plantation are there in Great Britain yielding such a crop? For 100 acres which will carry that amount there are probably a million of so-called plantation that will not average per acre, when fit to cut, 3,000 cubic feet of inferior, coarse, and mixed timber, the only reason being want of knowledge in planting, thinning, and management, due to the exigencies of lifeownership and the baneful influence of the Scottish system.

Natural mixed forest.

Mixture by groups.
Regarding the mixing of different species on the same ground, Nature teaches that, as a rule, each species occupies its own position, depending on latitude, aspect, elevation, and soil. But often two congenial species coincide in their choice of locality, as in Europe spruce and silver fir keep to the cool slopes of hills facing north, and are found highest up, while trees of the genus pinus prefer the sunny sides of the hills and various elevations, some higher, some lower. Where these areas overlap one another there are mixed forests. Hard-wood trees, such as oaks, beech, and acacias, have a greater tendency to mix. Deciduous trees come in climates intermediate between evergreen pines and evergreen tropical species, such as sal and saj, and among the immense numbers of different species found in India there must be a more or less mixed condition of the forest; but such mixture is most frequently by groups or patches, one sort following the sides of streams, another preferring steep and rocky precipices, another warm, sheltered valleys, another swampy flats, another dry uplands. Differences of soil also induce certain varieties, and the nature of the subsoil, whether sandy or clay or rocky, or of gravel or loose boulders. Every change of species has a reason, and the effect of given conditions is constant. 
In Nature there is no jumbling up of various incongruous species over the whole forest, nor does one see starved and unhealthy trees with withered tops and decayed at the roots, so affected because they have been planted in a position unsuitable to their kind. Some species will mix very well together; an openheaded, deciduous kind gaining by contact with a close-headed kind, like pedunculate oak and beech, the latter improving the soil by its copious leaf-fall. Also a species that loves the shade of dark northern aspects, like silver fir, grows well with beech, which kills down the sun-loving pines, ${ }^{*}$ if wrongly mixed with such. The only advantages of mixing different species in artificial forests are that a judgment can be formed as to which tree grows best, and the other kinds can be cut out. This is a clumsy and unscientific method; but in natural forest mixtures are usually by groups, and it is not safe to plant trees in a jumble. If the object is to cover the ground, mixtures may succeed, but if the object is to grow the best timber-especially deals and pines-the unmixed Highwood system is the one which, from its agreement with Nature and its simplicity, is to be relied on as economical in its working and, when once established, capable of yielding the best results.

The dropping of seed by parent trees on the ground is found in natural forests to be usually effective in keeping up an unfailing supply of seedling plants, which grow up in masses wherever the winged seeds are carried by the wind. In India the process, when fires are excluded, goes on most successfully. Some years are specially good seed years, and some, when the rain comes at the right moment, are good years for germinating. In time the whole area gets sown, and the young trees grow up so rapidly that the differences of age do not count much after a few years, and the forest is renewed. Replanting is resorted to in Highwood systems, where it may be found to pay better. Natural seeding is practised commonly, as less costly. It is promoted in Highwood culture by leaving a few parent trees standing when the final crop is being felled. These cast their seeds on the freshly bared land, and the sun soon causes germination and a rapid growth of the new crop sufficiently evenly over the land. Then the parent trees are felled.

Artificial mixtures must follow Nature.

Economy of unmixed Highwood.

Nature's methods of replanting. 
Nature's

method of thinning to be imitated in forest management.

Wrong systems of thinning.

Productive of coarse, worthless timber.
Thinning is a most important operation, which the careful observation of Nature's method alone can teach. It has been the subject too often of mistakes and misunderstanding. The object being to get the most valuable timber, and not coarse, worthless, loose-grained stuff, the seedlings must be allowed to grow a head, and not interfered with until the master trees have fought out their battle for life and killed down the weaker ones.

In Highwood forest, where the seedlings grow very close together, or where planting has been at 3 feet apart, the first thinning will amount merely to taking out the dead poles, perhaps at the thirtieth year. The complete canopy must be preserved overhead, which draws up the young trees lean and straight, until they attain nearly their full height and are standing about 6 feet apart, or 1,200 to the acre. The thinnings will then take place at intervals of thirty years, care being taken to keep the trees growing on in height. Finally, they are thinned out to I 2 feet apart, or 200 to the acre, and then they begin to thicken, which goes on for the rest of their time, either I00 or I 20 years. One hundred trees per acre is sometimes sufficient for the final crop.

In countries where schools of scientific forestry do not exist, and where neither owner nor forester knows on what system or rotation he is working, or what was the mind of the original planter--perhaps long since dead--thinning is usually conducted after a method, or rather no method, which is entirely wrong. The ideas inculcated are to thin out freely and give plenty of room, in order that the trees may grow as fast as possible and develop fine heads. Leaves are the lungs of the tree, by which it imbibes carbon from the air and builds up its stern, so that abundant foliage produces rapid thickening long before the stems have cleaned themselves of knots, and the annual rings or layers of fibre are put on so coarsely and thick that the timber will be loose-grained and worthless. When after some years the uneducated forester comes round, he marks these well-grown trees as fit to cut, and the owner congratulates himself on having so great a bulk of timber to sell. But the purchaser finds them half sap and dozed at the roots, and unfit for joiners' work, upon which he gives a very small price. And sage opinions are pronounced that good deal or pine cannot be grown in Great 
Britain. But the fault is in the wrong and unscientific management, and not the soil or climate.

The celebrated Norway pine, or red deal of commerce, is the same tree as our indigenous Scotch fir, and can equally well be grown in England. If we examine a plank of good Norway red deal, or Memel, we find the layers of the grain or annual rings are Io or I 2 to the inch, all dark coloured, with no sap and few knots. If we examine the rings of Scotch fir, thinned out too early on Brown's principle, we find they are pretty close in the centre. The year when the early thinning occurred is easily discerned by the sudden widening out of the annual rings to probably four to the inch. The heart-wood is like a dark core in the centre, and outside is white sap-wood full of knots. Boards cut out of such stuff are of quality the very worst. The stems of the trees are thick, but very deficient in height, and scarcely pay for sawing.* Douglas spruce, if grown close together, as in Vancouver Island, where the climate is similar, will produce in this country the most excellent of all spars and deals, i 50 feet long. Corsican pine would produce a pine-wood equal to American pitchpine. The qualities of larch, which grows to perfection in England, are well known; but though these trees are tolerably rapid in growth, the attempt to force them up too quickly for an early realization of their value has produced disease and failure.

These lessons from Nature apply to all kinds of forests all the

* Here are the actual measurements of Scotch firs grown in Ireland:

Lessons taught by Nature and in forest schools.

Pine and deal timber can be grown in Eng. land equal to the best.

\section{Growun 30 to the acre, with spreading crouns.}

Girth, 5 feet.

Height, 50 feet.

Age, 40 years.

Diameter, 20 inches.

Rings per inch, 4 (uneven).

Thickness of heart-wood, I 2 inches.

Thickness of sap-wood, 8 inches.

These trees are very quickly grown on deep, soft soil, liable to be blown over, timber coarse, knotty, worthless, and light and perishable, fully 4 inches of sap-wood under the bark.
Grown 200 to the acre, with small crow'ns.

Girth, 5 feet.

Height, 75 feet.

Age, 100 years.

Diameter, 20 inches.

Rings per inch, Io (regular).

Heart-wood, 19 inches.

Sap.wood, I inch.

These trees were slowly grown on a hillside on poor and stony soil; standing together they resist storm. Their timber is fine-grained, hard, heavy, durable, and equal to the best Memel, scarcely any sap.wood. 
Different systems as subjects of study.
Courses of study in subsidiary opera. tions. world over, and can be learnt by long and bitter experience, but much more cheaply by studying at the forest colleges, where the results of experience in every system can be compared. The 'Manual of Forestry,' by Dr. Schlich, is an excellent textbook.*

I will only touch upon the various systems of getting timber off the land in the most profitable way, as practised largely in Germany, France, and other countries, to suit the different requirements of different localities.

They are taught in forest schools as follows :

\section{HIGHWOOD SISTEM, WITH CLEAR CUTTING.}

Renovation :

I. By planting.

2. By self-sown plants (by compartments, groups, and single trees).

Coppice wood:

I. With standards.

2. Without.

\section{AUXILIARY SYSTEMS.}

1. High forest with standards.

2. Two-storied high forest.

Then there are taught rules for mixing different species and for renewing the proper kinds.

There are rules for managing forests where the trees are of one age or two ages, of the same species and of different species, and rules for managing forests where the trees are of all ages, to the best advantage and on the most scientific principles.

The various methods of cutting the timber and transporting it by slides and sledge-ways down to the rivers, as practised in the Vosges and Black Forest, are taught, and are all-important to a forester. Even the simple mechanical dodges for loading logs on to carts, in which Americans are proficient, are worth studying. The transport of timber over ice and snow, in which Canadians excel, the floating of timber in streams at flood-time, whether at the thaw, as in Canada, or by damming of the stream and artificial floods, as practised in the Black Forest, are separate and important forest operations. Then the forester must learn how to construct big rafts, as on the Rhine and St. Lawrence, and

* Mr. Simpson's book, called 'The New Forestry,' is likewise excellent. 
float them down torrents and rapids to the sea. The building and working of saw-mills, run by water-power or by steam, must be studied, and the cutting up and final marketing of timber.

At the forest schools all possible requirements of the forester are the subject of long and elaborate courses of study, besides such subjects as mathematics, mensuration, and mechanics-in short, a complete scientific education is given.

The profession of forestry is in Germany looked upon as on a par with that of the barrister, engineer, or medical man, and, being a State service, possesses permanent advantages and emoluments.

England has allowed her forests to disappear-a very sad and lamentable thing, in view of the fact that other countries in Europe are utilizing the good gifts of Nature and bringing the cultivation of timber to the highest perfection, for the benefit of the people who dwell on the land and of the country generally.

The able-bodied population of the country is permitted in England to flock to the towns and live like Chinamen in filthy tenements, or, as in Ireland, to emigrate to the States and flood our markets with American produce, while thousands of acres of land which would grow splendid timber are lying derelict, and the natural protection of the soil which trees afford is finally disappearing.

While other countries of the world make laws and tariffs to encourage the culture of every produce of the soil, and plant a thriving peasantry on the land, our politicians are too busy making laws for the protection of the labour monopolies of the towns to pay any heed to the cry for protection of the tillers of the soil, the stalwart but half-paid labourers on the land. The result is the gradual exclusion of English manufactures from all foreign markets, owing to dearness of operative labour, and the disappearance of the country population and its dispersion across the Atlantic. Add to this the ever-increasing drain on British resources to purchase the wheat and timber no longer produced at home, which must lead, in case of war, to disastrous famine and collapse of all industry and desertion of the islands, which have been swept clean of all that should, under natural conditions, grow on the land. Coal and iron cannot be worked without timber, and still less without wheat, and the population will

Profession of forestry.

Review of the forest position in Britain.

Comparison with other European countries. 
Spurious free irade deprecated.

Replanting advocated.

Destructive influence can be arrested by legislation. assuredly move to where all four are found together. The remedy seems to be that our politicians should cease to focus their shortsighted eyes on the petty, small, and selfish doctrines of so-called and obsolete free trade, which is not free trade at all, but the protection of one class and the sacrifice of others-to wit, the dwellers on the soil. The replanting with trees (which 'do be growing while we are a-sleeping ') of one quarter of our islands now lying waste would not be the least important or least reproductive undertaking for our Government to adopt. Even if the forests of the whole world were in a state of original productiveness this would be economically profitable; but in view of the rapid exhaustion of the forests of foreign countries and our own colonies, is it not an imperative duty of our Government to look forward and restore the forests at home? Even fuel will become dear in a measurable time, owing to the great depth of the coal seams still unworked, and every stick grown will become more and more valuable, as in Germany, where it pays even to stub up the roots of the trees for firewood. In Ireland the case is even more deplorable. The politicians who should work for the interests of the people by protection of the staple products, corn and beef, play into the hands of the free-traders, so-called, who would unpeople the fields. Naturally the able-bodied inhabitants are adjourning to America, where Protection flourishes. The land is becoming waste, and every tree is being cut down. Even the game, which if protected would bring in wealth (as in Scotland), is being carefully exterminated, while the politicians seek to gain power and wealth by preaching disloyalty, hoping to weary out the democracy of England and its opportunist Government into further spoliation of the landed interests.

The restoration of forests is the only possible influence on climate which may delay the inevitable doom of all plant and tree life on the earth and its relapse into barren desert-a relapse now steadily progressing, partly through the destructive energy of the British race all over the world. It is time that some check were put by legislation to such devastation and waste, which, with redoubled force, is constantly increasing. The freedom of man to lay waste the resources of Nature and appropriate its rich stores to his present use for present gain, entirely regardless of future generations, and entirely neglecting to replant-that is 
the saddest result of the fetish set up by British politicians, and called 'free trade' - a fetish which in other matters besides the destruction of forests all over the world is hastening the ineviBritish free trade influence table catastrophe. That it may long be deferred is the fearful prayer of all thinking men who have seen the immense destruction in the last fifty years of tree and forest life; the extermination of whole species of forest inhabitants, and the rush of so-called civilization to appropriate the lands of other people of inferior race; the rapid exhaustion and desertion of the virgin soils recently reclaimed from forest; the wasteful burning of coal and timber, and even straw; and the digging of the gold with frantic A policy of greed. haste and subsequent desertion of the gold-fields, left waste and disfigured.

The greatest question of the twentieth century will be the prevention of food famines and carbon and timber famines. The devastation of forests which once covered the land, and the extravagant waste of Nature's products which has occurred during the nineteenth century, must, I think, as population increases and American soil becomes exhausted, bring about such famines, followed by wars of extermination in Europe.

That an old Indian forest officer, who has seen the result of forest destruction in India, should be impressed with such considerations, and endeavour to place on record these impressions, is no wonder. He must admire the great work done by the Government of India with a view to develop its teeming resources, including Forest restoration. Already the organization of this department, commenced thirty odd years ago, has laid the foundations of vast improvement, financially and economically, as the latest Indian forest report amply shows.

If these pages prove in any way useful to those who at home or in India desire to study the subject, also if they awaken in the minds of lovers of the forest an increasing interest in forest conservation all over the world, the writer of these recollections will be amply rewarded.

Indian forests successfully rescued. 


\section{N D E X}

AGE of tiees, $33 \mathrm{I}$

Alaknanda river, $38,179,186$

Amarkantak, 279

Ammonites, I 59

Anjun (Hardwickia binata), 294

Antelope, Indian, 259, 275-277

Tibetan, I 30 . See also

Gazelle, Gooral, Serow

Api mountain, 87, 95

Arna. See Buffalo

Axis, or spotted deer, 198, 235, 240

Badrinath, 44, 45
Bagesar, 67, 70
Bagra, 297
Balch Dhura, I 49, I 56

Balsam, intoxicating, I7 I

Bamboos, 267, 308

Ban chowr. See Yak

Banian-tree, 259, 299, etc.

Bansi, Rajah of, 24 I

Baobab-tree, 268

Barasingha, or swamp deer, I99, 312

Bareilly, I, 195, 199

Bayley Balfour, Professor, 322

Lear, habits of, 30, 97, I 7 I

Himalayan black, 54, 64, I 7 I-

I 75, $177-179$

brown, 96, 97

Terai black, 246, 295

Betwa river, 266, 27I

Bhabar, 4, 6, 21, 38, 194-212

unhealthiness of the, 197

Bhot, country of, 87

Bhotia ponies. See Gunt

Bhotias, 86.89, 92, 135, 152, 162, I66- 168 lihuk grass, II 7

Bians district, 86, 91

pass, 93, 106, I 32

Birds, lists of species observed, I 48, 209-2 I I, 246, 247, 300-303

Bison, or gaur, 286-288, 295, $31 \mathrm{I}$

Black buck, 259, 275-277

'Bokhara' horses, 47, 243

Borax, trade in, $87, \mathrm{I} 35, \mathrm{I} 6 \mathrm{I}$

Bori forest, 203, 312

Brahmaputra, sources of, 116,123 , $127,129,133$

'Brain-fever' bird, 29

Brandis, Sir D., xiii, 318, 319

Bridge-making, 2 I, 297 native, 68 , Iog, i 5

Brinjaras, 270 their dogs, 260, 270

Buddhism, I I 4, 200, 304

Buffalo, 237, 26I wild, 228, 234, 237-240, 243245

Bundelas, 262

Bundelkhand, 258 ct seq.

Burning ghats, 70

Burrhel (Ozis nahura), 95, 96, 99, 153,156

Camels, 259, 296

Carbon, loss of, through destruction of forests, 322, 338, 339

Catechu, 255, 271

Cattle-bells attract tigers, 23, 33

Cedars of India, 4I, 49, 75

Chandgarh forest, 293-295

Chaudans district, 86

Chipula, mountain, 77-79, $81,8_{3}$

Chir (P'inus longifolia), 6, I 5, 76, 184-I86, etc. 
Chital, or spotted deer, 198, 235, 240

Chough, I 35, I 37

'Coppersmith' bird, 301 , etc.

'Cotton soil' in Bundelkhand, 263

Crocodiles, 25 I, 252

Crops in Gorakhpur, 229, $23 \mathrm{I}$

Cypresses, 6, 42

Dahya system of cultivation, 269 , 286

Dak Eo Pass, II7, I19, I3I

Dalhousie, Lord, 29I

Deer, barking, i 6, 206

four-horned, 259

hog, 198, 235

musk, So, 96

six-tined (Sambur), 35, $201-$ $203,312-315$

spotted, 198, 235, 240

swamp, or twelve-tined, 199, 312

Deodars, 4I, 49, 75

Dhak-tree, 28, 213

Dharma district, $86, \mathrm{I} 68$

Dhauli river from Niti valley, 49 , $50,64,66$

in Dharma valley, 86, I 59

Dogs, Brinjara, 260, 270

Tibetan, 89

wild, I 50, 313.317

Dooly, travelling by, I, 2, 5

Dotials, I9-2 I

Drongo, racket-tailed, lesser, 2 Io greater, 300

Drummond, Hon. R., 74, 77, 90, I I6, I 24, I 30, I 3 I, I 34

Drummond, Lieutenant-Colonel, 39

Dudhi, Jain temple at, 27I

Duksam, I 29

Ebony, 254, 259

Elephants, I96, 213, 2 I6, 217, 2 I9, $221,223,225,236,241,248$ 250

wild, 9, I99, 222, 3I I

Evergreen-trees really deciduous, 28,233

Fairies, worship of, 32, 59, 87, 9I, I $40,176,200,270,295$

Fevers, $5,48,64,196,298$
Fig-trees of India, I $\mathcal{0}$, 232, 255, 305

Flies, plague of, I70

Florikins, 226

Forest Department in India, xiii, 283,291

in Colonies, 323

equipment, $46-48$

fires, 40, 197, 289, 309, 330

products, $254 \cdot 256,307,308$

Survey, $38,40,43,5$ I, I84, 227,257

Forestry honoured abroad, 337 misunderstood at home, xii, $320,327,332$

Forests, destruction of, in British Empire, 266, 268, 32 I324,337

in other countries, 323 , 327-329

in Garhwal and Kumaon, 38-43, I79, I80, I84-186, 194,198

in Gorakhpur, 227, 235, 252

in Jhansi district, 266

in Native States, 89, 267

in Nerbudda district, 283,289 , 292

Free Trade, 338, 339

Gandak river, 227, 251

Ganges, sources of, 38,44

dead committed to, 70

Gangotri, 38, 44

Garbyang, 92, 94, 98

Garden, an Indian, 282

Garhwal province, 44,184

Gaur, or bison, 286-288, 295, 3I I

Gazelle, chinkara, 259, 26I, 262 goo, I3I, I 48

Germany, birthplace of forestry, 29I, 3I

Glaciers, $51,136,164$

Goats carrying loads, 47, 88, 89 shawl, I I 3, I 50

Gonds, 279, 286, 295, 314, 316

Gooral, or Himalayan chamois, 9, $79,186,187$

Gorakhpur, 227, 228, 23I, 233, 252

Gori river, 76, 77, I68

Gunt ponies, 5, 31, 47, 87, 152, I 88

Gurkhas, 21, 27 
Gurla Iandhata mountain, 105, II 7, I 2 I, 125, I 33

Gwalior, 257

Gyanima, I 38

Harda, great heat at, 293

Hares, tameness of, 127, I $_{3} 8$

Heights, measurement of, 64, I 19

Himalayas, 73 first view of, 4 great scale of, I 59 peaks in, 56, 86 seen from Bhabar, 200

Hinduism, 275, 304

Hochwald system, 319, 331, 336

Hodgson, Mr. H., 74, I20, I 23 , $124,128,134$

Hornbill, 7

Hoshangabad, 2So, 293, 296

Hundes, 94, 107

Hunias, 93, 94, 106 et seq., I I7, 129, 132, I 50, I6I

Huns, 94, 107

Hutchins, Professor, on forestry, 322-325

Hyena, 205

Icebergs in lake, I 20

Iron-workers, native, 19, 20, 267, 271

Irvajung mountain, 86, 9 I

'Jacko,' pet monkey, I7

Jalaun district, 274 town, 277

Jamun-tree, 2 I 3,294

Jerow. See Sambur

Jhansi, 257, 258, 265

Jhobu, hybrid yak, 95, I22, etc.

Juhar district, 86, I6 I

Juli, 19, 22 man-eating tigers at, 26

Jung Bahadur, 24 I, 245

Jungle-fowl, cry of, 208

Kailas, sacred mountain of, I I I, 126

Kakur, or barking-deer, 16, 206

Kali river, 76, 82, 86, 87, 95, I 34

Kalij pheasant, I6, 209

Karnali or Koriali river, I09, II 5

Karnprayag, 44, 45

Kiang, wild horse, I18, I37, I 57

Koel, cry of, 302
Kosila river, 66, 7 I

Kumaon, 86

forests of, $6,38-43$

natives of, 2 I, 22, etc.

villages of, 22,75

Kuti Pass, 134, I 36

Kyungar Dhura, I 49, I 59

Lalitpur, 257, 27 I

Lamas at Taklakhar, I I I, I I4

Lammergeier, I93

Landor, Mr. H. Savage, I66

Langur monkeys, 4, 78, 206, 235

Laptel, I 57, I 59

Lark, 126, 148, 207 crested, 304

Lata Forest, 49, 63

Leeches, 76, I69

Leopard, S9, I86, I S9 et seq. snow. $54,57,63,80$

Lhasa, attempts to reach, 92, $16_{3}$, 165

Limi mountain, I2S

Lyall on upheaval of mountains, 164

Machan for tiger-shooting, 27, 33

Mahadeo, 289, 290, 308

Mahseer fishing, 65 et seq.

Mahua-tree, 229, 232, 282, 305

Manasarowar lake, 110, I 2,117 , I26, I66

Mango-tree, 229, 232, 305

Manure not required in India, 264

Mariam La, 130

Marmots, I I 8,135

Martens, 205

Milam glacier, $51,76,163,164$ pass, 149 valley, 86 village, 162

Milk, goat's and sheep's, I30, I 5 I

Monal pheasant, 64, 8 I

Monkeys, age of, I8

Mora flies, 77, 169

Mosquitoes, 77, 169, 197

Nountain climbing, 53, 55, 99, 187

Musk deer, So, 96

Naini Tal, 5, 8, 9, I2

Namjung mountain, 87, 9I

Nanda Devi, 44, 49, 50, 56, 57, I63, I68, etc.

Kot, 5 I, 76 
Nari Danda, 82, 84

Nepal, 98

forest in, 235,245

hunting party in, 242

Nerbudda river, 279-281, 294, etc.

Nilghai, 198

Nirpani, 9 I

Niti, 49, 86

Nullahs, country cut up by, I53. I 56, 274

Nyang. See Ozis Ammon

Oaks, evergreen, 6, I80, I86

Orchha, 266, 267

Oriole, golden, 24 , 301 , etc.

Ovis Ammon, I24, I3I, I38, I40 et seq., I 53, I 57 , I 59

parent of domestic sheep, I 44

Pachmari, 290, 297, 305

Palms, 6, 256

Paroquets, 302, etc.

Partridge, black, 207, 248 peura, 30, 209

snow, 148

Pepper, 233

Pigs, wild, I98, 219, 22 I

Pheasants, I6, 64, 79, 8I, I48, 209

Pilgrims to Ganges source, 44

Pindar river, I68, I79, I82 glacier, 179

Pines of India, 4 I et seq., $3_{3}$, etc. of British Isles, 326, 335

Plover, spur-winged, 2 I I

Poles, huts built on, 237

Polyandry, I I2, I 67

Praying-machines, I I I, II 2

Quail, 208

button, 209

Rainfall, I 2, 10.4, I 34

Ram Ganga river, 26, 66, 76, I68, I 96

Ramsay, Colonel H., 9, Io, I I, 48, I 95, 2 I 4, 2 I6, 224-226

'Rani's fan' (breeze called), 28, 209

Rarefied air, effects of, 97,99, 103, I 06, I I9, I 2 I, I 32, I 38 , I 39, I 40, I 52
Re-afiorestation of British Isles, 325,338

Ritles and ammunition, 30, I47, I 54, 2 I $8,238,240$

Rindi valley, 50,56

Rishi river, 50

Road-making, I0, I I, I6, 17, I9, 2 I

Roller, the Indian, 300

Rosewood, 259

Sahariyas, 268-270

Saj-tree, 6, 232, etc.

Sal-tree, 6, 21, 194 et scq., 232, 296 , etc.

Salt, trade in, 87, 88, I35, I6I, 273

hedge, the, 273

Sambur deer, 35, 20I-203, 312, 313,315

Sarju river, 67, I68, I 86, I96

Satpura hills, 279, 281, 284, 29I, 297

forest report on, 292

Schlich, Dr., 322, 324, 325, 33I, 336

Schools in Kumaon, I34, I63

Semal-tree, 28, 232, etc.

Serow, or jungle antelope, 203, 204

Sheep carrying loads, 88, I6 I

Tibetan, 93, 1 29, I 30

wild, 93, 95, 96, 131, 144, I 45

Small-pox and vaccination, 98

Smyth, Lieutenant-Colonel, 74, 92, 106, 109, I I6, 123, 130, 134 , 135

Snakes, 2 I I

Snow-blindness, 74, I03, I I9, I32

Spear-grass, 169

Spider, giant, 2 I 2

Squirrels, $30 \mathrm{I}$ flying, 90

Strachey, Sir R., I 22, I49, I 64

Sunari Forest, 233

Sutlej, sources of, I 49, I 53

Taklakhar, 92, 95, I05 et seq., I 32

Tamarind-tree, 282

Tapoban, 50

Tarshish perhaps Mysore, 307

Tea, I 30,18 I

Teak-tree, 258, 259, 284, 285, 287

Teal, houses for fattening, 247 
Terai, I, 5, 6, 196, I97, 2 I 3 et seq. in Gorakhpur, 227 in Nepal, 245 et seq.

Thar (Hemitragus jemlaicus), 52, 55 et seq., 62, 79

Thunderstorms, 58, 175

Tibet, I I 4, I 65 contrasted with India, 103 , I04, 136, I6 I

difficulty of entering, 94, I66 author's journeys in, I02-I33,

$$
\text { I 34-16 I }
$$

Tiger, 23 et seq., 198, 219.224, etc.

a man-eating, 27, 30

and boar, 2 I 9

and cow, 225

and elephant, 216, 217,225

invisibility of, $25,35,22$ I

vitality of, 36,224

Tiger-cat, 242

Tinkar, 98

pass, 95

amazing view from, 103 , IO4

Topidunga, precipice at, 160
Tornadoes, 229-232

Travel, old methods compared with new, 3

Trees, various lists of, ISo, I8I, I $84,198,254 \cdot 256$

Trisul mountain, 50, 160

Unta Dhura, I6I, I62

Urial, wild sheep, 145

Vegetation, various descriptions of, 28, 32, 79, 180, 309

Vultures, 224

Water-wheels, 265

Webber, Major-General, 266

Williamson's 'Sports of the East,' 3 I 6

Wolves, 27 I

Wool, 96, I I 3, I 23, I 46

'Working-plan' in forestry, 252, 3I9, $32 \mathrm{I}$

Yak, 95, 96, I02, I 19, I 22, I 30, I 34,160

wild, I I 6 , i 22 et seq.

THE END 
1 

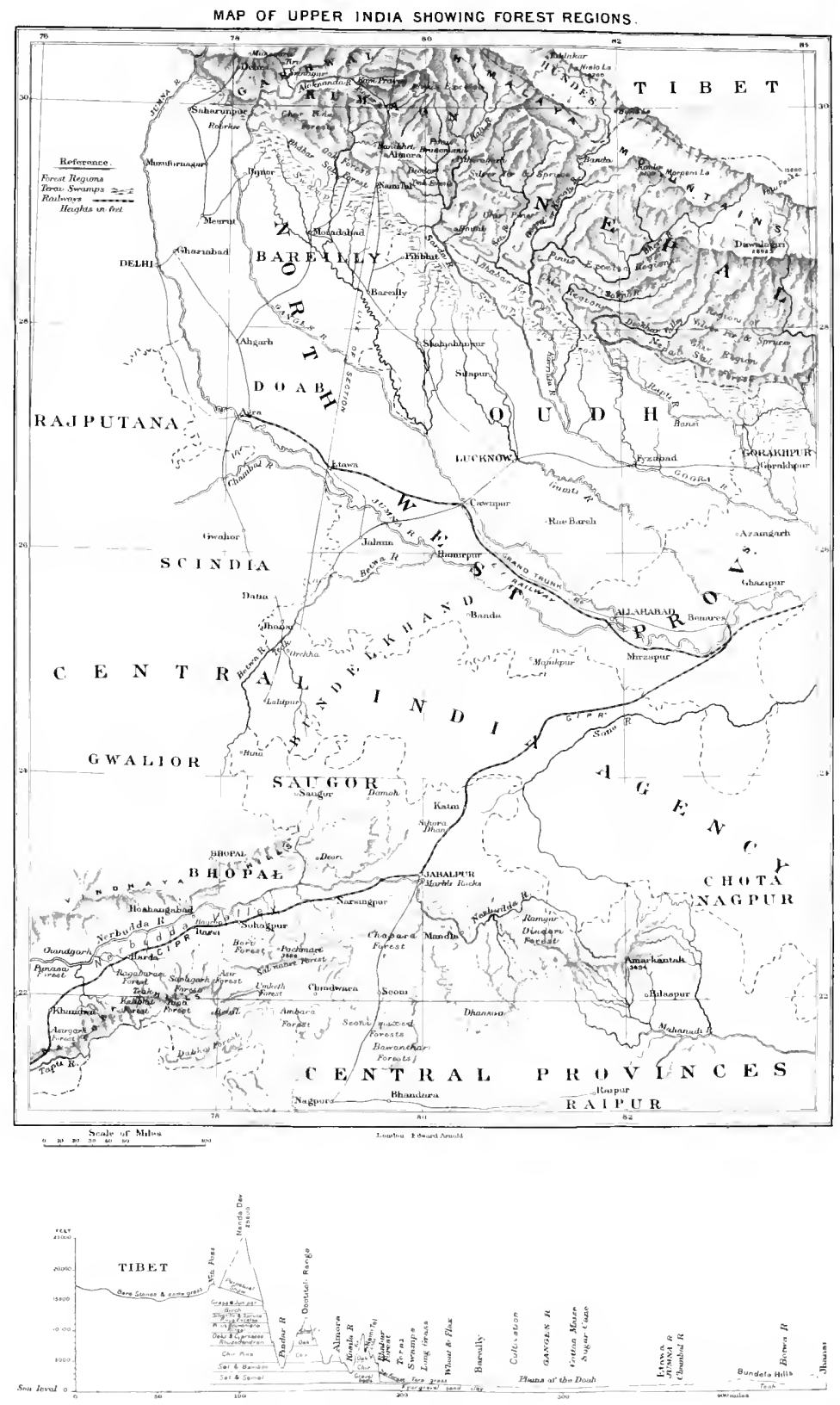


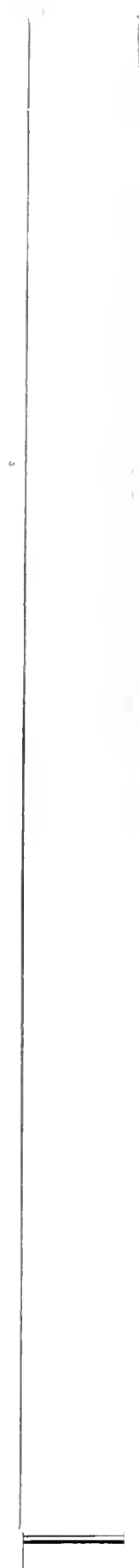



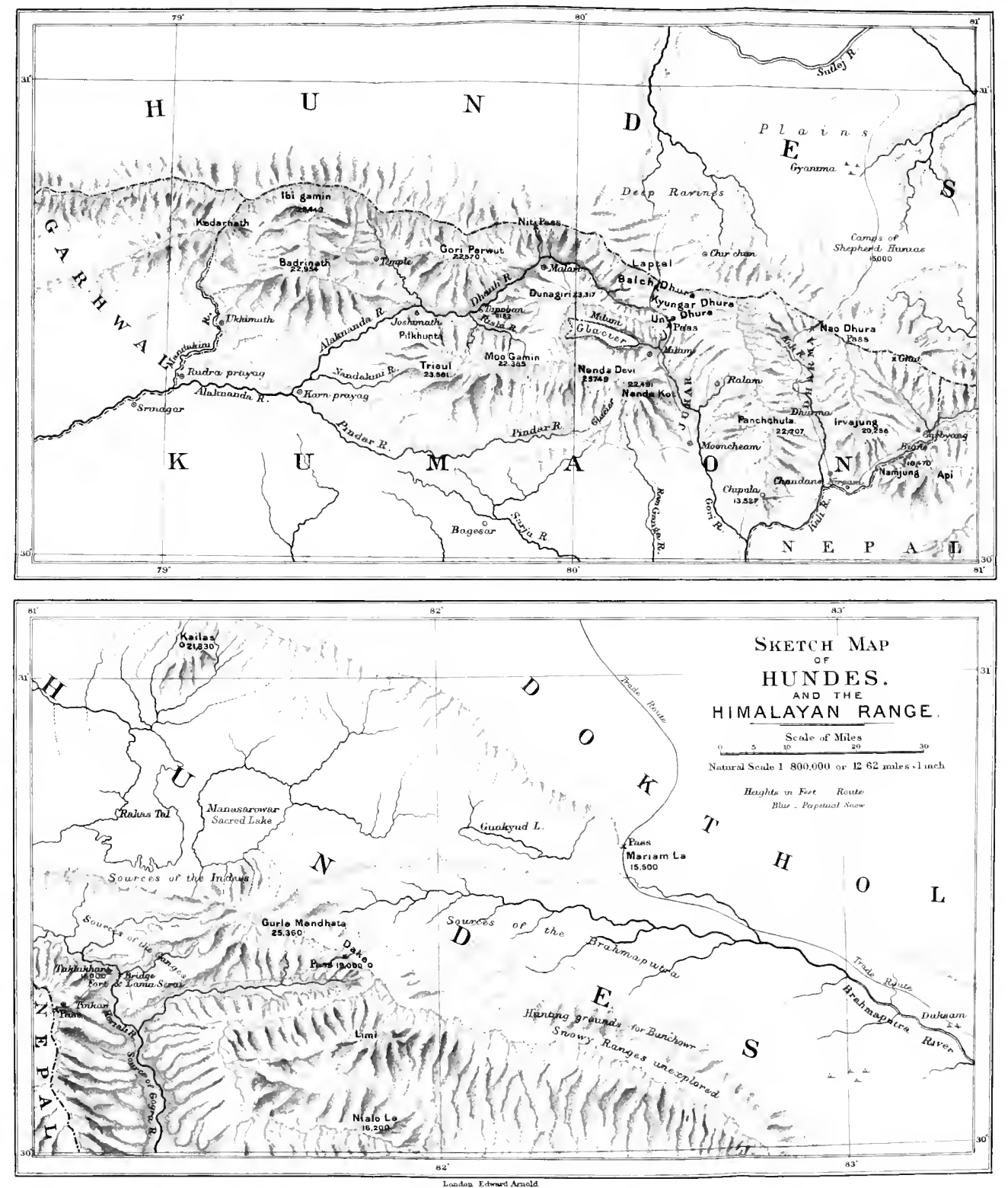

University of California

SOUTHERN REGIONAL LIBRARY FACILITY Return this material to the library from which it was borrowed.

RET TO L

JAN 211992

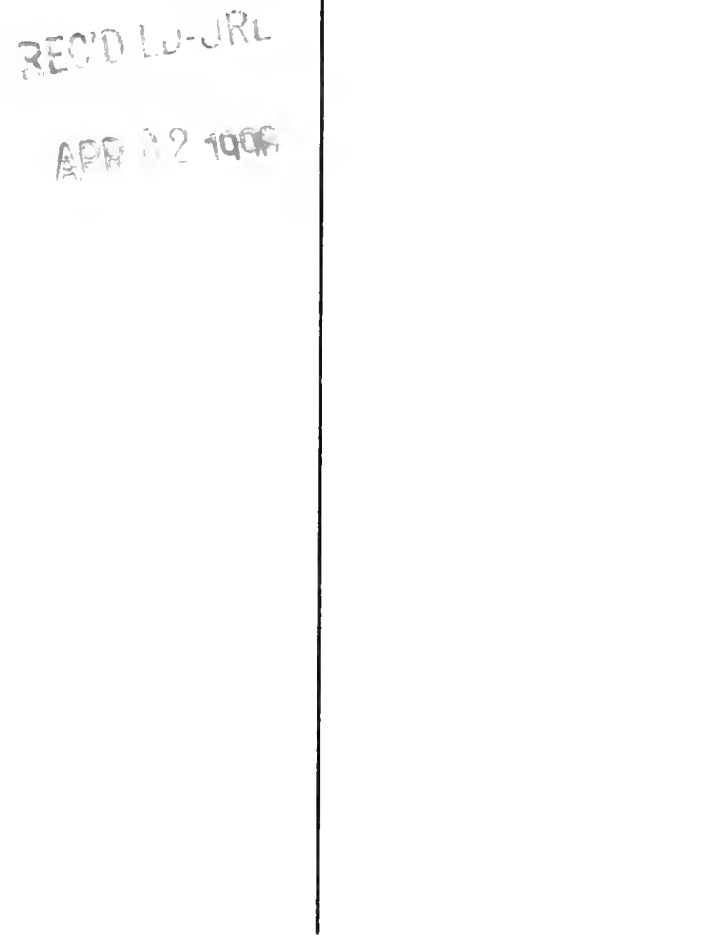




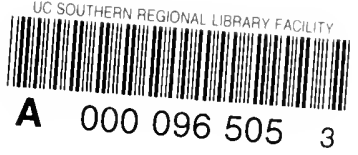


